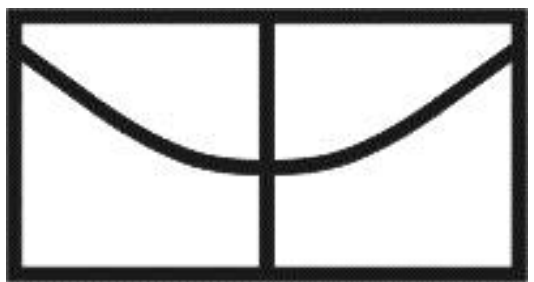

UNIVERSIDADE DE BRASÍLIA FACULDADE DE COMUNICAÇÃO PROGRAMA DE PÓS-GRADUAÇÃO LINHA IMAGEM E SOM

DENISE MORAES CAVALCANTE

\title{
CINEMA DE FICÇÃO CONTEMPORÂNEO E MODOS DE HABITAR TRANSITÓRIOS
}




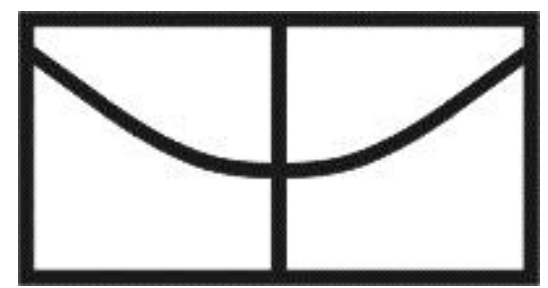

UNIVERSIDADE DE BRASÍLIA FACULDADE DE COMUNICAÇÃO PROGRAMA DE PÓS-GRADUAÇÃO

LINHA IMAGEM E SOM

\section{CINEMA DE FICÇÃO CONTEMPORÂNEO E MODOS DE HABITAR TRANSITÓRIOS}

Tese apresentada ao Programa de Pós-Graduação em Comunicação da Universidade de Brasília como requisito para obtenção do grau de Doutor em Comunicação Social, pela linha de Imagem e Som.

Orientadora: Prof. Dra. Tânia Siqueira Montoro 


\section{CINEMA DE FICÇÃO CONTEMPORÂNEO E MODOS DE HABITAR TRANSITÓRIOS}

Tese apresentada ao Programa de Pós-Graduação em Comunicação Social da Universidade de Brasília, e defendida sob avaliação da Banca Examinadora constituída por:

Profa. Dra. Tânia Siqueira Montoro

Orientadora

Universidade de Brasília

Prof. Dr. Marcelo Feijó Rocha Lima

Membro Interno

Universidade de Brasília

Profa. Dra. Cláudia Naves David Amorim

Membro Interno

Universidade de Brasília

Profa. Dra. Ludmila de Lima Brandão

Membro Externo

Universidade Federal de Mato Grosso

Profa. Dra. Florence Marie Dravet

Membro Externo

Universidade Católica de Brasília

Profa. Dra. Karina e Silva Dias

Suplente

Universidade de Brasília 
Para minha mãe. 
AGRADECIMENTOS

Ao Fernando, Gabriel e Arthur, pelo amor e inspiração.

A Tânia, pela dedicação e orientação.

A minha irmã pelo auxílio e carinho.

Ao meu pai e meus irmãos pelo estímulo incondicional.

Aos amigos Solange Lima; Cristina Hori;

Lucila Esteves; Sonia Dias; Daniel Genty;

Mike Peixoto, Érika Bauer, Mauro Giuntini, Delcia Vidal, pela torcida e amparo.

Aos professores Gustavo de Castro e Michel Maffesoli, pela sabedoria compartilhada.

Aos professores Nancy Berthier e Alberto da Silva do CRIMIC pelo acolhimento e contribuição.

Aos diretores, professores e funcionários da

Faculdade de Comunicação da Universidade de Brasília pelo apoio institucional.

A CAPES, pelo apoio financeiro à pesquisa. 
"Fisicamente, habitamos um espaço, mas, sentimentalmente, somos habitados por uma memória".

(José Saramago) 


\title{
RESUMO
}

MORAES CAVALCANTE, Denise. Cinema de ficção contemporâneo e modos de habitar transitórios. 2014. Tese (Doutorado em Comunicação) - Curso de Pós-Graduação em Comunicação Social, Universidade de Brasília, 2014.

Orientadora: Profa. Dra. Tânia Siqueira Montoro. Defesa: 09/12/14.

Esta tese se constrói sobre a premissa de que há uma reconfiguração de modos de habitar representados no cinema mundial contemporâneo. Seu objeto são filmes de ficção de diferentes nacionalidades inseridos em um contexto de imaginário diante das problemáticas do mundo urbano globalizado. Levando em conta alterações no modelo narrativo do gênero cotidiano, buscou-se investigar modos de habitar construídos em transitoriedades de espaços e personagens.

Palavras-chave: Cinema; Espaço; Casa; Habitar; Contemporaneidade.

\begin{abstract}
This thesis is built on the premise that globalization dynamics are reshaping the representation of houses and ways of inhabiting in the contemporary world cinema. This study aims fiction films of different nationalities inserted in a context of imaginary among the problems of the urban world, combining space, place and characters. For this, it is evident the changes in narrative model of the everyday genre, considering the transitory use and appropriations in domestic space.
\end{abstract}

Key words: Cinema; Space; Home; to inhabit; Contemporaneity 


\section{SUMÁRIO}

APRESENTAÇÃO

\section{CINEMA DE FICÇÃO E GÊNERO COTIDIANO}

1.1. Cinema ficcional e representação ...................................................................19

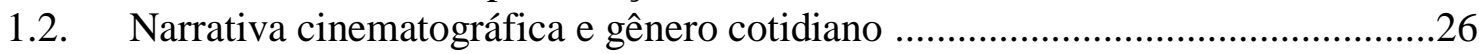

1.3. O homem cosmopolita no cinema mundial contemporâneo .................................35

2. ASPECTOS FORMATIVOS DO ESPAÇO FÍLMICO

2.1. O indefectível espaço fílmico ............................................................................43

2.2. O espaço diegético em filmes de ficção .................................................................49

2.3. A dimensão sonora na percepção do espaço .......................................................55

3. MODOS DE HABITAR EM FILMES DE FICÇÃO

3.1. Modos de habitar como topografia fílmica ......................................................62

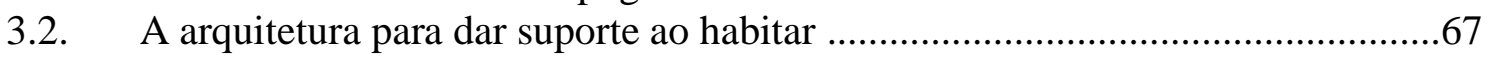

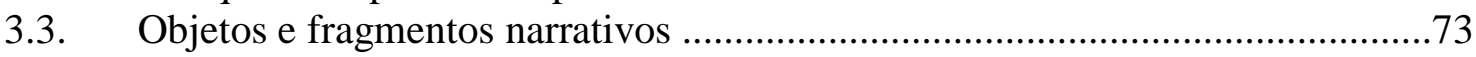

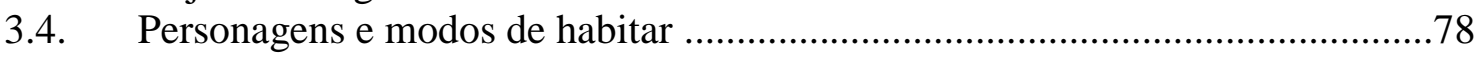

4. COSMOPOLITAS E MODOS DE HABITAR TRANSITÓRIOS ....................85

4.1.Um conto chinês de Sebastián Borensztein

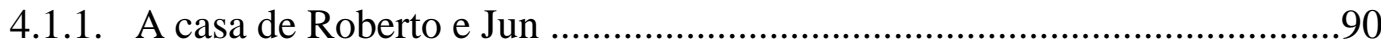

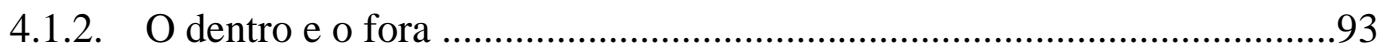

4.1.3. As práticas de espaço ..........................................................................98

4.1.4. Os detalhes narrativos: pequenas coleções e ferramentas .......................103

4.2. Encontros e desencontros de Sofia Coppola

4.2.1. Charlotte e Bob habitam em um hotel ...................................................109

4.2.2. O quarto e a cidade .......................................................................... 112

4.3. Louise Wimmer de Cyril Mennegun

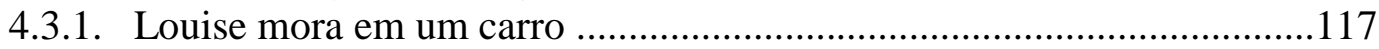

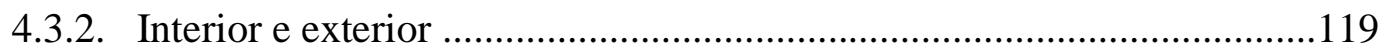

4.3.3. A ausência da casa .....................................................................122

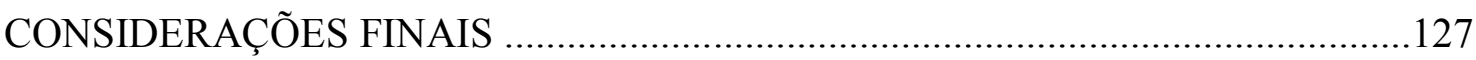

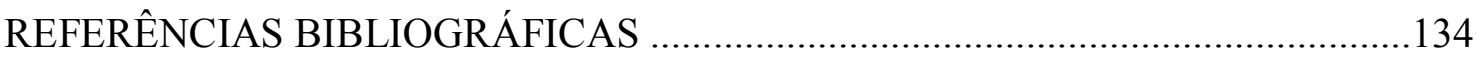

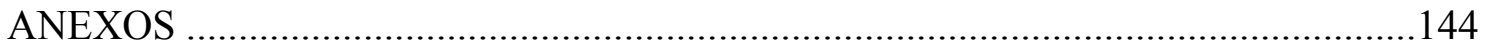




\section{APRESENTAÇÃO}

Este trabalho de pesquisa tem como objetivo central investigar a representação de modos de habitar urbanos em filmes ficcionais, dimensionando tensões entre espaço e personagem no cinema contemporâneo. Grande parte dos estudos narrativos no âmbito do espaço fílmico se concentra na relação entre cidade e cinema, examinando suas múltiplas interações e a contribuição do cinema na formação de imaginários urbanos. $O$ diferencial deste trabalho se apresenta na investigação de experiências de mobilidade apresentadas em imagens cinematográficas a partir do espaço íntimo da casa, indagando como modos de habitar são construídos em filmes de ficção, em um entrelaçamento de visualidades, sonoridades e espacialidades. Espera-se contribuir para os estudos do espaço narrativo cinematográfico, entendendo-o enquanto possibilidade reflexiva diante das transformações vivenciadas no contexto da sociedade atual.

Como aluna do curso de mestrado do Programa de Pós-Graduação em Comunicação Social da Universidade de Brasília, desenvolvi a dissertação Imagens do cotidiano no cinema brasileiro: olhar sobre a casa, defendida no ano de 2005 sob orientação do professor doutor Denilson Lopes. O trabalho em questão consistiu em uma análise comparativa da representação da casa rural nos filmes brasileiros Eu, Tu, Eles (2000) de Andrucha Waddington e Abril Despedaçado (2001) de Walter Salles, tendo como base o estudo do espaço doméstico associado a uma poética do cotidiano no cinema. Esta tese de doutorado dá prosseguimento à pesquisa de mestrado, partindo agora em busca de modos de habitar transitórios no cinema de ficção contemporâneo delimitando fronteiras entre espaço narrativo e personagens desterritorializados.

Ainda que esta pesquisa se concentre no campo do cinema, a definição de espaço do geógrafo Milton Santos propicia introduzir nosso objeto e iniciar uma contextualização: “espaço é um conjunto indissociável, de que participam, de um lado, certo arranjo de objetos geográficos, objetos naturais e objetos sociais, e, de outro, a vida que os preenche e os anima, ou seja, a sociedade em movimento" (2008, p.28). Santos questiona o espaço como dado imutável e eterno. Em sua concepção, a transformação de aspectos quantitativos e qualitativos do espaço habitado como a expansão da população mundial, a diluição de fronteiras entre nações, o processo de urbanização, o fluxo de informações e de pessoas em grande escala, revela o dinamismo da vida societária. Cada sociedade abastece o espaço de novos significados e cada forma espacial contém frações 
da sociedade que a acolhe. Em uma sociedade mundial, o espaço torna-se mundial. A mundialização das relações sociais, econômicas, políticas e culturais altera as dimensões geográficas da atividade humana, provocando uma nova organização societária baseada na heterogeneidade e na hierarquização do espaço. Milton Santos (2007, 2008, 2009) afirma que uma sociedade produz, em seu tempo, seu próprio espaço. Em seus estudos sobre o espaço geográfico, nos aponta um olhar crítico diante do espaço, apreendendo-o enquanto realidade relacional. Para ele, estudar o espaço em que vivemos possibilita compreender quem somos.

Investigando as transformações ocorridas na sociedade contemporânea a partir do espaço vivido, percebemos indícios de um cotidiano diversificado e menos rotineiro, conduzido de modo flexível e ambientado em lugares múltiplos e variáveis. Comemos na rua, trabalhamos em casa, moramos em hotéis. Dormimos no aeroporto, residimos com desconhecidos, manifestamos afetos no ciberespaço. Vivemos virtualmente a cidade, habitamos em deslocamento. O mundo ficou mais urbano e as formas de habitar na contemporaneidade estão marcadas pela fluidez e mobilidade. "Enquanto os sólidos têm dimensões espaciais claras [...], os fluidos não se atêm muito a qualquer forma e estão constantemente prontos (e propensos) a mudá-la", escreve o sociólogo polonês Zygmunt Bauman. (2001, p.8). Ao observar o processo de modernização da sociedade a partir de uma metáfora, Bauman associa a característica fluida dos líquidos a conceitos básicos da condição humana, entre eles, o espaço.

De Bauman, adotamos a metáfora. Antes associado à solidez e inércia, o espaço agora nos toma pela diluição de fronteiras, forma e função encontram-se alforriadas. $\mathrm{O}$ espaço não se prende, permuta; flui, transborda, vaza; é liquidez, se dissolve; é transitoriedade ambulante. Em um cenário de globalização, aqui entendida como um processo multifacetado que redefine o jogo entre global e local em meio à compressão do tempo e do espaço, formas de sociabilidade se constituem em espacialidades erguidas por experiências fluidas em circuitos de interações comunicativas e afetivas. As práticas sociais e as relações interpessoais são afetadas pela estruturação e organização dos espaços e pela maneira de estar no espaço social. O homem desenraiza-se e alcança novas dimensões espaciais: comunica-se instantaneamente; no interior de um espaço privado se expõe publicamente; armazena dados e documentos em um lugar virtual; localizado fisicamente em um espaço, presentifica-se em outro. As linhas que separam espaço local e global, interior e exterior, espaço público e privado se dissolvem porque a própria noção de espaço é dissolvida. 
As distâncias já não importam, ao passo que a ideia de uma fronteira geográfica é cada vez mais difícil de sustentar no 'mundo real'. [...] Com efeito, pouca coisa na experiência atual de vida da elite implica uma diferença entre 'aqui' e 'acolá', 'dentro' e 'fora', 'perto' e 'longe'. Com o tempo de comunicação implodindo e encolhendo para a insignificância do instante, o espaço e os delimitadores do espaço deixam de importar, pelo menos para aqueles cujas ações podem se mover na velocidade da mensagem eletrônica. (BAUMAN, 1999, p.1920).

As mudanças espaciais reformulam as dimensões urbanas e domésticas da vida cotidiana. A princípio, espaços públicos se apresentam como lugares acessíveis e impessoais, enquanto a esfera privada se reconhece como o espaço da família, oculto a olhares estranhos. Entretanto, dentro dos domicílios é possível encontrar fragmentos de uma vida pública, enquanto em lugares públicos há vestígios de intimidades. Em uma sociedade em que tudo parece se liquefazer, é impossível sustentar imposições funcionais e estéticas nos modos de concepção das cidades e suas edificações. Livres da especificidade arquitetônica, ambientes se configuram de modo flexível, reinventando lugares múltiplos estruturados em relações transitórias: habitações se erguem permeadas pelo que é efêmero e errante; espaços públicos e privados se renovam amplificados pela dinâmica urbana; paisagens cotidianas se constituem em itinerância; casas flutuam, deslocam-se, desdobram-se, transmutam-se. Tantas fragmentações e permeabilidades impedem o delineamento de limites rígidos e aprovam inúmeras configurações.

Em um espaço amorfo e mutante, o homem condiciona atividades fragmentadas transpondo fronteiras e emoldurando práticas desterritorializadas, afirmando um modo fluido de vivenciar a contemporaneidade. No ensaio O que é contemporâneo?, o filósofo italiano Giorgio Agamben define contemporâneo como "aquele que recebe em pleno rosto o facho de trevas que provém do seu tempo" (2010, p.64). A dinâmica da globalização é um "facho de trevas" que impõe ao homem da contemporaneidade uma mobilidade permanente. Uns se movem por vontade, outros por necessidade, mas moverse nos dias de hoje é um imperativo. Evidências empíricas no cotidiano, desde um simples itinerário rotineiro modificado pelas tecnologias da comunicação e informação até a intensificação dos fluxos migratórios internacionais, afirmam a mobilidade na ressignificação e reorganização dos espaços das cidades contemporâneas.

Geralmente associada ao espaço urbano, a noção de mobilidade nesta tese se explicita, sobretudo, a partir do espaço doméstico. As mutações da sociedade nos diversos níveis da vida cotidiana vêm provocando uma alteração no modo como as pessoas 
circulam e permanecem não apenas nos espaços da cidade, mas também nos ambientes íntimos e domésticos. O homem da contemporaneidade se move incessantemente em espaços que se confundem - espaços privados que são públicos, habitações rurais permeadas pela tecnologia digital, carros que são casas, casas-escritórios, hotéisresidências, etc. -, demarcando territórios cada vez mais híbridos. A diversidade dessas moradas exprime a existência de homens de hábitos nômades, ações simultâneas e encontros efêmeros, provocando modos de habitar contemporâneos. Ao mesmo tempo, "a progressiva segregação espacial, a progressiva separação e exclusão", apontadas por Zygmunt Bauman (1999, p.9) como consequências humanas da globalização, se evidenciam na atual problemática da moradia urbana. As formas de habitar nas cidades refletem sociedades desorganizadas e desiguais que sujeitam seus habitantes a espaços precários, enquanto outros privilegiados se cercam em condomínios luxuosos. Diante da fragilidade e reformulação dos espaços urbanos, encontramos tantas formas de habitar quanto indivíduos díspares, concebendo modos transitórios de se apropriar e se lidar com o espaço.

$\mathrm{Na}$ confluência de espaços fluidos, híbridos e provisórios, há como pensar em modos de habitar próprios da contemporaneidade? Para o filósofo Martin Heidegger (2005a, 2005b) ser alguém que habita um mundo - um ser-no-mundo - é uma característica ontológica fundamental do homem. Ao habitar o mundo, a experiência humana se torna possível. Segundo sua concepção, habitar não é somente morar em uma residência: um motorista se sente em casa em uma autoestrada; uma tecelã está em casa em sua tecelagem. Habitar é o modo como os homens são e estão sobre a terra. Investigar as formas de habitar o espaço urbano nos parece um caminho possível no encontro com "homens da contemporaneidade" e no entendimento de um sentido de pertencimento a um tempo e um lugar determinado. Quais seriam, então, as características das casas que habitamos hoje? Moradas nômades, desenraizadas, transitórias? Em que medida a intensificação da mobilidade urbana, de informações e de pessoas incide sobre a configuração dos espaços domésticos? Qual a relação entre a vida cotidiana na sociedade contemporânea e modos de habitar transitórios? Não se trata aqui de buscar respostas a essas perguntas em experiências vividas, nos edifícios ou casas que moramos, nem tampouco no modo como estamos ou permanecemos em espaços reais, mas sim tentar refletir sobre essas questões a partir do cinema de ficção contemporâneo.

Se geógrafos e sociólogos preveem a dissolução do espaço geográfico e social, cineastas e estudiosos do cinema há muito diagnosticam o fim do cinema. Em 1991, o 
cineasta francês Jean-Luc Godard escreveu o poema La paroisse morte ${ }^{1}$ onde, de certa forma, previa a morte do cinema. Em suas palavras, a separação entre filme de ficção e documentário, a garantia do direito de autor, os problemas da teoria da montagem, entre outros, revelavam as incertezas do dispositivo cinematográfico. Nos dias de hoje, continuamos testemunhando mudanças e rupturas em diferentes dimensões do cinema, concebendo novas formas de se fazer e se exibir filmes. Hoje, parece impossível apontar a nacionalidade de um filme ou afirmar para quem ele se destina. Ao mesmo tempo, a indústria cinematográfica se mundializa: é possível verificar nas salas de cinema, o aumento de filmes produzidos em co-produções internacionais, filmes de múltiplas nacionalidades realizados em um país e finalizados em outro, ou mesmo diretores filmando em países estrangeiros, evidenciando a natureza transnacional do cinema.

Quando se fala de cinema de ficção mundial contemporâneo, fala-se de narrativas cinematográficas ficcionais de diferentes nacionalidades inseridas em um contexto de imaginário coletivo que articula vivências diversificadas do espaço, porém posicionadas em semelhantes percepções sobre as mudanças espaciais e humanas sofridas na contemporaneidade. Nesse cinema, proliferam-se filmes em que a cidade e seus habitantes aparecem como protagonistas mobilizados pelas dinâmicas da globalização, mediando imagens de imigrantes, cosmopolitas, expatriados, mas também espreitados, desamparados, deslocados que deambulam, trafegam, circulam de carro, de metrô, a pé em ruas, avenidas, edifícios, aeroportos, postos de gasolina, hotéis e casas. Se as cidades afiguram no cinema associadas à violência urbana, à solidão, ao desconhecido, as residências seriam então os espaços da família, do resguardo, da proteção? Diante de um mundo que se esfacela e que transmuta incessantemente, como manter a casa de pé em um sentido de edificação estável, lugar de segurança e espaço de abrigo?

A mobilidade que dissolve e transforma o espaço na contemporaneidade chega aqui pela porta da casa. Esta tese tem o objetivo de identificar e dimensionar a reconfiguração de novos modos de habitar em filmes de ficção do cinema mundial diante da presença de personagens inseridos em contextos urbanos. Pretende-se apreender um imaginário da morada do homem contemporâneo no cinema perante às mutações espaciais do mundo urbano com tudo que isso possa implicar em desconstrução de um sentido previsível e estereotipado. Nesse entendimento, o termo "modos de habitar" nos pareceu uma alternativa para narrar casas que se constituem enquanto imagens

\footnotetext{
1 Poema em anexo.
} 
cambiantes, buscando encontrar "homens contemporâneos" e suas formas de habitar em narrativas ficcionais. Afinal de contas, onde habitam os protagonistas cosmopolitas desenraizados ou deslocados?

Para tanto, é preciso investigar, por meio da análise de filmes de ficção, o que oferecem as moradas como possibilidades narrativas, levando em conta as dinâmicas urbanas da contemporaneidade. A maneira como o cinema contemporâneo vem trabalhando novos modelos narrativos para dar conta das reconfigurações do espaço social, de um lado implica em expor certa transitoriedade nas diferentes formas de se habitar o mundo, de outro propõe um deslocamento em uma forma rígida de se conceber as narrativas fílmicas.

Esta pesquisa se desenvolve à luz de um referencial qualitativo que se propõe à compreensão particular das interpretações das realidades sociais, a partir de uma abordagem dedutiva com base investigativa. Situa-se no campo da Comunicação, mais especificamente em cinema, na linha de pesquisa Imagem e Som, direcionada para as discussões teóricas e metodológicas articuladas com as práticas culturais e experiências sociais dos sujeitos na contemporaneidade e compreendendo os meios audiovisuais como "um amálgama complexo de sentidos, imagens, técnicas, composição de cenas, sequência de cenas e muito mais" (ROSE, 2002, p.343). Inserida no âmbito dos estudos do cotidiano no cinema de ficção, mais especificamente do espaço fílmico, a tese tem como ponto de partida modos de habitar transitórios como meios de expressão na busca de novos modelos narrativos com referência à sociedade globalizada atual.

Como resultado de um estudo e levantamento bibliográfico, investiu-se em um quadro teórico na interseção de dois caminhos: o primeiro a partir das possibilidades de entrelaçamento entre ficção e realidade, investigando um conceito de ficção não apenas sujeito à representação, mas próximo a "mundo ficcional" e a possíveis sentidos que se desprendem da materialidade fílmica ${ }^{2}$; o segundo se deu na ânsia de encontrar uma definição para o termo narrativa cinematográfica, postulando-se um vínculo com um possível gênero cotidiano. Abordar esta pesquisa a partir de um ponto nodal ou de uma encruzilhada conceitual oferece a seu objeto maior - o cinema - uma certa ambiguidade que, de todo modo, lhe pertence. Como arte, o cinema se define em sua dimensão

\footnotetext{
2 "O conceito de materialidade não se opõe ao de matéria; vai além. A matéria é a preocupação mecânica com o suporte material, ao passo que a materialidade abrange o potencial expressivo e a carga informacional destes suportes, englobando também a extramaterialidade dos meios de informação". (LAURENTIZ, 1991, p. 102). É necessário pontuar que nem só de aparências se faz a imagem cinematográfica, sua materialidade se constitui de sensações, percepções e imaginações.
} 
filosófica e se aproxima do inapreensível: construído de materialidades, converte o concreto em abstrato. É sempre uma dimensão transitória, apreende o real e o transmuta em imagens; da imaginação faz substância. Tenta passar a verdade pela aparência, mas é pura ficção. Como ideia se refaz ao ser consumado; como produto pronto (o filme) se recompõe no encontro com seu "leitor". Não tem pertencimento: não pertence ao roteirista que o entrega ao diretor; não é do diretor pois é obra coletiva; e passa da coletividade para o imaginário de uma só pessoa, e depois para o de um monte delas. Afinal de contas, o cinema é de todos, e um pouco de tudo.

Uma primeira abordagem conceitual vincula este estudo a um entendimento de espaço existencial onde sensibilidades e percepções outras se fazem presentes. Apagando sua existência como dispositivo - "nada de cinema"3 - deixa transparecer outras geografias como formas de conhecimento. Ao se apropriar do espaço urbano ou doméstico, propõe ver em proximidades e distanciamentos esses lugares, tomando-os como fronteira, percurso, espaço ambulante... Ao contrapor ficção e realidade, procurase pensar um conceito de representação que isente o espectador de uma posição submissa e iludida, e que não esteja pautado no entendimento de imagens e sons como significantes. Para tanto, buscar uma relação com o real, isto é, com os espaços sociais e geográficos em transformação da contemporaneidade, é inserir esta pesquisa em um contexto histórico, em uma conversa com seu tempo, o tempo presente.

A segunda abordagem pensa o espaço a partir de sua vinculação com a narrativa fílmica em uma análise mais formal. Cada narrativa pontua um elo com a realidade. Experiências vividas são retomadas em diferentes leituras, e cada uma dessas narrativas oferece um sentido que acaba por determinar sua coesão como um todo. Estudar o modo pelo qual os filmes elaboram um sentido para esses novos modos de se narrar um lugar valoriza suas dimensões fílmicas e o que é perceptível na variabilidade de suas imagens e sons. Nessa vertente, a intenção é encontrar em suas materialidades, elementos comuns que possam reunir as narrativas em um objeto de pesquisa incorporado a uma mesma família cinematográfica, no caso, um possível "gênero cotidiano".

Partindo desse quadro, uma indagação norteadora da pesquisa se evidenciou: como se manifestam os modos de habitar enquanto possibilidade narrativa em filmes ficcionais do cinema mundial, levando em conta temáticas urbanas com referência ao mundo contemporâneo e sua transitoriedade? Diante dessa problemática, outras questões

\footnotetext{
${ }^{3}$ Expressão de André Bazin (1991, p.277).
} 
mais específicas foram definidas e orientaram a pesquisa realizada: Em que medida o cinema recente tem reconfigurado a representação da casa e de modos de habitar diante das experiências da dinâmica urbana? Como narrar modos de habitar em filmes de ficção? Como os lugares e os fragmentos arquitetônicos dão suporte para a edificação de espaços narrativos? Qual a relação entre modos de habitar e personagens em narrativas ficcionais? Que conjuntos de singularidades trazem essas moradas que as fazem conjugar com as mudanças espaciais experienciadas na contemporaneidade? Mais do que delimitar o tema, essas indagações procuram fornecer sondagens no estudo do espaço narrativo em filmes de ficção.

Após a formulação da questão principal e de questionamentos pontuais, e dos estudos teóricos e reflexões realizadas, passamos para a elaboração das hipóteses com o intuito de direcionar nossas investigações e análises futuras, definidas como:

1. A presente tese vislumbra a hipótese de que, no cinema mundial contemporâneo, evidenciam-se alterações no modelo narrativo do gênero cotidiano: o "homem comum" assume o papel de "homem da contemporaneidade", transmutando-se em "homem cosmopolita". A renovação se dá diante da reformulação de suas práticas cotidianas e nos modos de habitar repletos de transitoriedades evidenciadas em narrativas fílmicas de ficção.

1.1. Para edificar e narrar modos de habitar em um filme ficcional é necessário constituir uma organização espacial, denominada topografia fílmica, entre diferentes elementos narrativos como espaço, lugar e personagem, bem como na relação entre filme e espectador. Na busca dessa edificação, reconhece-se duas dimensões espaciais:

1.2. A primeira leva em conta sua "constituição física" que se serve do espaço experienciado por meio da arquitetura, de elementos arquitetônicos e de objetos (aqui estamos falando de edifícios, casas, fachadas, cômodos, portas, janelas, mas também mesa, armário, fechadura, etc.). Nos filmes, os lugares se edificam por meio de fragmentos espaciais, em planos e enquadramentos, que renunciam a um suposto objeto real e a suas dimensões físicas para reconstituir-se de outro modo, a serviço de uma narrativa específica inserida em temáticas e contextos próprios;

1.3. A segunda leva em conta a constituição do lugar como espaço habitado, isto é, na relação que se estabelece entre espaço e personagens em diferentes contextos: seja de identificação, evocando o "mundo íntimo" dos personagens, seja em um contexto situacional apontando a narrativa como percurso de espaços. 
2. Diante das mudanças sociais e espaciais vivenciadas na contemporaneidade, outros espaços têm assumido o sentido de casas em filmes ficcionais do cinema mundial. Deste modo, existe uma reconfiguração do entendimento da morada como espaço seguro e abrigado em contrapartida a um espaço constituído na dinâmica de mobilidades do mundo urbano. Uma vez desarticulado de um modelo narrativo rígido para se pensar esse lugar, pode-se falar da existência de modos de habitar transitórios constituídos em narrativas fílmicas. Para tanto, sua configuração e apreensão se relacionam com:

2.1. A inserção de personagens em instâncias narrativas de mobilidade e deslocamento no espaço da casa, questionando seu sentido enquanto território fixo, estável e seguro, apontando para sua identificação como "espaço-ligação";

2.2. O entendimento do espaço narrativo como elemento embrionário para a composição de personagens deslocados e de temáticas de transitoriedade no cinema de ficção.

2.3. A reconfiguração de dicotomias espaciais (dentro e fora, exterior e interior) e a alteração de usos e apropriações costumeiras dos lugares pelos personagens;

2.4. Espaços de trânsito como hotéis, aeroportos, postos de gasolina, e também carros vêm assumindo um sentido de morada e instaurando novos modos de habitar o espaço urbano, afigurando a desconstrução total de uma imagem pré-concebida da casa.

A tese se organiza em quatro capítulos. O primeiro capítulo apresenta um quadro teórico-metodológico, resultado de um levantamento bibliográfico estruturado em abordagens conceituais que investigam o cinema de ficção para além de uma simples representação da realidade, e em uma narratologia que reconhece a classificação desse cinema em gêneros cinematográficos, não como fórmulas representacionais, mas assinalando pontos comuns que se desprendem das próprias narrativas. Para tanto, seguiuse dois caminhos: o primeiro se centraliza no realismo ontológico de André Bazin, com o intuito de refletir sobre o elo entre cinema e realidade e, ao mesmo tempo, recorrer a um entendimento de representação que considera as dimensões estéticas, subjetivas e narrativas do dispositivo cinematográfico; o segundo se estrutura nas abordagens narratológicas de André Gardies e André Gaudreault, que pensam a narrativa do cinema em suas singularidades e elementos constitutivos (personagem, ação, espaço, tempo), e no estudo de gênero do filósofo Stanley Cavell para reconhecer um gênero do cotidiano que dê conta das narrativas do cinema, abordando as experiências da vida do dia-a-dia. De um cinema manifesto diante da dinâmica dos processos de globalização, apreende-se a imagem de homens cosmopolitas e espaços transitórios implicados em novos modelos 
narrativos em filmes de ficção contemporâneos. Encontrar um conjunto de materialidades fílmicas que constitua modos de se habitar na contemporaneidade solicita, mais do que analisar rupturas do dispositivo cinematográfico, investigar sentidos e subjetividades alicerçadas em uma imaginação criadora própria de cada filme.

O segundo capítulo investe nos aspectos formativos do espaço fílmico apoiados nos conceitos de espaço diegético e espaço narrativo apresentados por André Gardies, tomando como ponto de partida os estudos de filmologia do pesquisador francês Étienne Souriau. A conceituação segue outros desdobramentos formais para se pensar o espaço como a relação entre o quadro e ofora-de-quadro, estudada em autores como Noel Burch, André Bazin e Gilles Deleuze. Na constituição de uma diegese, o espaço criado pelo som é tão importante quanto ao proposto pela imagem, o capítulo traz, então, um aprofundamento sobre a relevância da materialidade sonora para a percepção do espaço fílmico.

No terceiro capítulo, investiga-se a constituição de modos de habitar em narrativas ficcionais do cinema, iniciando-se com o aprofundamento do conceito de topografia filmica apresentado por André Gardies, entendido na interseção entre espaço, lugares e personagens, e entre filme e espectador. A proposta é instaurar o habitar enquanto lugar narrativo edificado em uma "dimensão material", investigada junto aos estudos da arquitetura, mais precisamente dos fenomenólogos Christian Norberg-Shulz e Juhani Pallasmaa. Ao mesmo tempo, a contraposição entre espaço e lugar oferece uma base conceitual para refletir uma possível "dimensão existencial" que se figura diante do modo como personagens habitam os espaços em ações que suscitam um sentido de vida cotidiana. Parte-se da premissa de que a percepção fenomenológica libera a análise narrativa de certos formalismos, admitindo a interdisciplinaridade como possibilidade metodológica da pesquisa e, ao mesmo tempo, restituindo à imagem cinematográfica certa subjetividade.

O quarto e último capítulo traz as análises dos filmes: Um conto chinês (2011) do diretor argentino Sebastián Borensztein, Encontros e desencontros (2003) da diretora americana Sofia Coppola, e o filme francês Louise Wimmer (2012) dirigido por Cyril Mennegun. A proposta é verificar as hipóteses elencadas em modos de habitar edificados nas narrativas ficcionais do cinema mundial contemporâneo, entendendo-as como "percursos de espaço". Mais do que seguir um único trajeto, caminha-se atravessando cinema e arquitetura, espaço e personagem, na tentativa de fundamentar hipóteses e questionamentos em uma espécie de reconciliação entre o espaço vivido e aquele 
construído pela ficção. Destacadas as singularidades de cada filme analisado, busca-se encontrar imaginários de modos de habitar com referências às dinâmicas da sociedade globalizada.

O conhecimento que resultará desta pesquisa não está apenas voltado para a reflexão e o debate em torno das questões apresentadas, mas tem a intenção de sugerir caminhos para aqueles que produzem espaços no cinema e acreditam que a arte cinematográfica pode oferecer algo mais do que uma simples concepção cenográfica e representações fidedignas da realidade. A tese pretende valorizar o espaço cinematográfico como elemento fundante da narrativa cinematográfica, intervindo de maneiras específicas e em diferentes dimensões da ficção, produzindo espacialidades múltiplas as quais dão ensejo a implicações perceptivas, subjetivas, cognitivas e estéticas.

\section{CINEMA DE FICÇÃO E GÊNERO COTIDIANO}

\subsection{Cinema ficcional e representação}

Começamos esta investigação com uma constatação: o cinema vive uma ruptura em diferentes dimensões. A sala de cinema não é mais o único espaço de exibição para um filme que passa a adentrar galerias e museus; da película cinematográfica chegou-se ao vídeo e ao suporte digital alterando a tecnologia de captação e exibição dos filmes; novas câmeras de filmar aparecem a cada dia, agregando mobilidade e dinâmica aos modos de produzir e captar imagens e sons; o cinema interativo questiona o papel passivo do espectador e a própria autoria de um filme; há um aumento de coproduções internacionais, filmes com dupla nacionalidade ou filmes nacionais realizados por diretores estrangeiros, evidenciando a natureza transnacional da indústria cinematográfica mundial. Nessas afirmações, prevalecem as dimensões tecnológicas de captação e finalização de um filme, bem como as condições de sua projeção e distribuição. Porém, as transformações em curso não estão restritas a um sentido de dispositivo cinematográfico entendido como um aparelho de base e suas condições técnicas e produtivas, mas em uma noção mais ampla que abrange suas dimensões discursivas, figurativas e perceptivas da imagem.

Diante de um dispositivo marcado por sua dimensão tecnológica que implica em novas apropriações e manipulações de suas materialidades (imagens e sons), nos indagamos sobre a renovação dos modelos narrativos no cinema ficcional. As alterações 
de gênero, as interfaces entre ficção e documentário, a hibridação de linguagens são exemplos de possibilidades narrativas que implicam no modo como o cinema conta uma história. Novos conceitos surgem para dar conta dessas mutações: assistimos ao cinema expandido $^{4}$; de espaço imersivo passamos ao cinema interativo, do cinema dispositivo alcançamos o transcinema ${ }^{5}$. Ao mesmo tempo, a ideia do cinema como sistema de representação baseado na mimese ou como linguagem estruturada em códigos e regras linguísticas torna-se esgotadora, pois corre o risco de reduzir a narrativa a um enunciado e o cinema a imagens estereotipadas e homogêneas. Nesse entendimento, não há como negar o desaparecimento de uma forma convencional de se conceber o cinema.

Em seu artigo Cinema em trânsito: do dispositivo do cinema ao cinema do dispositivo, o pesquisador André Parente afirma:

Hoje, está claro que o dispositivo cinematográfico apresenta, ao lado de suas dimensões arquitetônicas e técnicas uma dimensão discursivo-formal ou estético-formal, que é peça fundamental na constituição de um modelo de representação institucional, cujas bases se encontram no cinema clássico, em particular no hollywoodiano (2007, p.8).

O conceito de representação, para esta pesquisa, não se sujeita à prevalência de um modelo narrativo convencional, intitulado por Parente como "Forma Cinema", que reflete um sistema hegemônico voltado para iludir o espectador. Trata-se de considerar o dispositivo para além de um sistema de correspondência entre signos e significações ou modelos prontos e esquematizados. O pesquisador trabalha o conceito de dispositivo a partir da "compreensão de que um único dispositivo pode dar lugar a diferentes modelos de representação e visões de mundo [...]. Ou seja, uma mesma mídia pode esconder, por detrás de sua aparente identidade, diferentes dispositivos" (ibidem, p.15).

Essa abordagem aproxima representação a diferentes pontos de vista de uma mesma realidade, apreendendo o dispositivo enquanto forma de expressão que conserva um vínculo com o mundo real, mas leva em conta suas inúmeras possibilidades estéticas e suas dimensões subjetivas e imaginativas. O termo é considerado, aqui, como formas de narrar que desprendem a realidade em perspectivas diversas de entendimento e

\footnotetext{
${ }^{4}$ Cinema expandido "designa formas de espetáculo cinematográfico nas quais acontece algo a mais do que somente a projeção de um filme [...]" (AUMONT; MARIE, 2003, p.111).

${ }^{5}$ Serve de referência os estudos da pesquisadora Katia Maciel e seu conceito de transcinema como "um cinema que experimenta novas arquiteturas, novas narrativas e novas estratégias de interação" (MACIEL, 2006, p.72), as reflexões de André Parente sobre as variações do dispositivo cinematográfico e experimentações no pós-guerra $(2000,2007)$, bem como as ponderações de Arlindo Machado (1997) diante do aparecimento do vídeo e da imagem digital.
} 
sentidos. Vale lembrar das reflexões do cineasta francês Robert Bresson (1988), que recusava o entendimento de cinema como representação. Para ele, a relação entre imagens e sons constrói verdadeiramente um filme. O cinema é como uma escrita que narra uma história com personagens, emoções, gestos, formas, luz, etc.

Mais do que pensar o cinema como representação, busca-se encontrar um elo entre cinema e realidade. Neste sentido, foi orientador o diálogo com o teórico André Bazin e seu realismo ontológico "que restitui ao objeto e ao cenário sua densidade de ser, seu peso de presença, realismo dramático que se recusa a separar o ator do cenário, o primeiro plano do fundo, realismo psicológico que recoloca o espectador nas condições reais de percepção (2005, p.92).

Em seu artigo Ladrões de bicicleta, escrito em 1949, o crítico analisa o filme neorrealista do cineasta Vittorio de Sica: “os acontecimentos não são essencialmente signos de alguma coisa, de uma verdade de que seria preciso nos convencer, eles conservam todo seu peso, toda sua singularidade, toda sua ambiguidade de fato" (1991, p.268). Bazin defende os princípios de uma estética realista ${ }^{6}$ baseada na transparência ${ }^{7}$, que no caso, se manifestaria na ausência de atores profissionais, no uso de cenários reais da cidade de Roma, e em uma mise-en-scène $e^{8}$ que deseja apenas mostrar os eventos como fatos reais. E finaliza: “Com isto, Ladrões de bicicleta é um dos primeiros exemplos de cinema puro. Nada de atores, de história, de mise-en-scène, vale dizer, enfim, na ilusão estética perfeita da realidade: nada de cinema" (ibidem, p.277).

Sua "estética da transparência" tem o intuito de que o cinema se sobressaia, não como dispositivo técnico reduzido a procedimentos técnicos ${ }^{9}$ e manipulações imagéticas mas, como dispositivo estético atento às possibilidades fílmicas, deixando transparecer um sentido real pleno de ambiguidades. A preocupação de André Bazin em traduzir uma vinculação do filme com o real não se acomoda apenas no estudo da dimensão estética-

\footnotetext{
${ }^{6}$ A teoria realista é também tema dos trabalhos do crítico Siegfried Kracauer. Sua estética material defendia a primazia do conteúdo em relação à forma artística. Para ele, "o cinema existe de modo mais profundo e mais essencial quando apresenta a vida como ela é" (ANDREW, 2002, p. 94). O estilo neutro procura respeitar as características naturais do evento, preservando a leitura da realidade de modo justo.

${ }^{7}$ A "transparência" do discurso filmico teria como base mostrar os eventos representados e não se deixar ver a si mesmo como filme (AUMONT, 2012, p. 74).

${ }^{8}$ Termo que teve origem na França a partir do teatro e que tem como tradução literal "colocar em cena", considerando a cena como o local de encenação, o espaço imaginário onde se passa o acontecimento diegético. No cinema, o conceito define o conteúdo presente no quadro (tela) e a forma como esses elementos são arranjados, movimentados e iluminados. No conteúdo estão incluídos o cenário, os objetos, os atores em relação ao enquadramento registrado pela câmera.

${ }^{9} \mathrm{O}$ conceito de "montagem proibida" é um exemplo destes procedimentos, na medida em que esclarece sua preocupação em mascarar o quanto possível as descontinuidades da montagem cinematográfica entre um plano e outro.
} 
formal da narrativa, mas pretende levar em conta o contexto social e cultural o qual se insere a obra analisada. A transparência defendida no filme de De Sica deixa expor em visualidades uma realidade local e ao mesmo tempo global: o homem e sua existência mundana.

Bazin argumenta: a "imagem pode ser nebulosa, deformada, descolorida, sem valor documental, mas ela provém por sua gênese da ontologia do modelo" (ibidem, p. 24). Sem demonstrar um anseio em tomar um pelo outro, o teórico chama a atenção para um vínculo que se estabelece entre objeto e seu modelo, considerando "uma transferência da realidade da coisa para sua reprodução" (ibidem, p.22). Seu realismo ontológico chama atenção para a presença real dos objetos e sujeitos filmados, mas também evidencia a percepção da imagem captada por parte do espectador.

\begin{abstract}
Seja qual for o filme, seu objetivo é nos dar a ilusão de estarmos assistindo a acontecimentos reais desenrolando-se à nossa frente como na realidade cotidiana. Mas essa ilusão encerra uma trapaça essencial, pois a realidade existe num espaço contínuo, com a tela nos apresentando efetivamente uma sucessão de pequenos fragmentos chamados "planos", cuja escolha, ordem e duração constituem precisamente o que se chama "decupagem" do filme. Se tentarmos, por um esforço de atenção voluntária, perceber as rupturas impostas pela câmera ao desenrolar contínuo do acontecimento representado, e de fato compreender por que são naturalmente insensíveis para nós, veremos na realidade que as toleramos porque, ainda assim, deixam subsistir em nós a impressão de uma realidade contínua e homogênea" (BAZIN, 2005, p. 89).
\end{abstract}

Em seu texto “a sétima arte segundo André Bazin”, Joël Magny procura compreender o modo como Bazin concebe o cinema enquanto ato de conhecimento, como possibilidade de encontro com o mundo. Como linguagem, o cinema apresenta uma necessidade de dar forma a uma imagem que deixa expor um ponto de vista sobre o real. “A significação final do filme reside mais na organização dos elementos (emprestados do real) que em seu conteúdo objetivo"10 (BAZIN apud MAGNY, 1991, p. 64), propiciando a construção de mundos fictícios. A fim de aprofundar possíveis elos entre modos de habitar o mundo contemporâneo e esses modos representados em narrativas cinematográficas, a ontologia de Bazin nos deixa afirmar que a imagem de uma casa construída em um filme ficcional contaria mais pelos sentidos que ela revelaria desse

\footnotetext{
10 "La signification finale du film reside beaucoup plus dans l'organisation des éléments (empruntés à la réalité) que dans leur contenu objectif” (N.T).
} 
espaço do que poderia acrescentar ao entendimento de uma noção de casa, e ainda "devolver ao filme um sentido de ambiguidade"11 (ibidem) percebido nas casas reais.

A objetividade fotográfica é um meio, não um fim. A imagem do mundo dado pelo filme é, apesar de tudo, uma imagem. Como o mundo, ela só existe percebida por alguém. É dentro da consciência do espectador que ela toma consciência. Este realismo se enraíza tanto no procedimento mecânico de sua produção quanto no ato subjetivo (a "crença" do espectador) de sua percepção ${ }^{12}$ (MAGNY, 1991, p.62).

A dimensão ontológica do cinema evidenciada na teoria de André Bazin implica em definir um conceito de ficção cinematográfica próximo a mundo ficcional e a pensar o lugar que ocupa o espectador na construção desse "mundo". Nesse ponto, os estudos do pesquisador Murray Smith sobre a instituição da ficção no cinema valorizam a dimensão imaginativa do espectador. Smith argumenta que o espectador (ainda que sentado em posição inerte diante da tela) não permanece passivo diante do que vê, mas "entretêm imaginativamente proposições e imagens dos textos ficcionais" (2005, p.154). As imagens e os sons de um filme são estímulos imaginativos que orientam e provocam sua imaginação.

Por um lado, os filmes de ficção nos brindam com complexos cenários narrativos, estimulando o envolvimento de nossa imaginação, de modo que os possamos fruir por completo; por outro lado, o cinema se caracteriza como um "dispositivo" com a capacidade, ainda que limitada, de induzir percepções e sensações que esperaríamos experimentar nas situações ficcionais para as quais ele estimula nossa imaginação (ibidem, p.156).

Imagens e sons oferecem uma aproximação às experiências sensoriais. As percepções experimentadas em vivências corporais no cotidiano servem na apreensão da ficção por meio da imaginação. Ao acompanhar as situações ficcionais vividas pelos personagens, o espectador se envolve com o filme abastecido por sua imaginação, e vê na imagem cinematográfica não uma ilusão, mas uma possibilidade de construção de um mundo ficcional apoiado na subjetividade. É a dimensão sensorial e imaginativa que enriquece a experiência de assistir a um filme. De acordo com o Smith, "as peculiaridades da nossa experiência ficcional são muito mais bem compreendidas

\footnotetext{
11 "Rendre au film le sens de l'ambiguïté du réel" (N.T).

12 “L'objectivité photographique est un moyen, non une fin. L'image du monde donnée par le film n'est, malgré tout, qu'une image. Comme le monde, elle n'existe que perçue par quelque'un. C'est dans la conscience du spectateru qu'elle prend consistance. Ce réalisme s'enracine autant dans le procéde mécanique de sa production que dans l'acte subjectif (la 'croyance' du spectateur) de sa perception” (N.T).
} 
utilizando-se os conceitos de atenção, imaginação, percepção e sensação que o de (falsa) crença" (ibidem, p.143). As matérias de expressão ${ }^{13}$ do cinema estimulam a dimensão sensorial e emocional do espectador, assinalando o ato de assistir a um filme como uma experiência fenomenológica.

Diferentemente dos primeiros tempos do cinema, o espectador de hoje não reage às imagens de um filme de forma ingênua, confundindo imagem e realidade ou desvirtuando o que a obra representa e a maneira como esse conteúdo é representado. Basta, para tanto, relembrar as primeiras sessões de cinema propostas pelos irmãos Louis e Auguste Lumière em 1895, na cidade de Paris, onde espectadores entraram em pânico ao verem a imagem de um trem em movimento. Hoje, o público de cinema é plenamente capaz de entender o vocabulário e a linguagem cinematográfica reformulada com o surgimento das novas tecnologias de filmagem e finalização. Para ele, uma elipse temporal, uma edição não-linear, os efeitos digitais apenas reforçam sua presença como participante ativo na constituição de narrativas ficcionais. Ainda que seja necessário esquecer (temporariamente) que um filme são imagens expostas em um espaço bidimensional (a tela) para desfrutá-lo enquanto mundo ficcional, o espectador não se ilude de forma ingênua e passiva: sabe se tratar de uma ficção, compreende seu dispositivo e ainda colabora na edificação de sua narrativa enquanto mundo ficcional construído em instâncias cognitivas e fenomenológicas.

A dimensão fenomenológica do cinema de ficção é tema de reflexão de J.Dudley Andrew (2002) em seus estudos sobre as principais teorias do cinema. O pesquisador aproxima a ontologia de André Bazin, em sua reflexão entre imagem e seu referente, a uma possível teoria fenomenológica do cinema, ressaltando a importância do teórico Amédée Ayfre na oposição à primazia da semiótica nos estudos cinematográficos: "a semiótica, como teoria e método analíticos, apoia um cinema que analisa o mundo, enquanto a fenomenologia nos oferece uma 'poética' que valoriza os grandes filmes sobre a vida, a unidade, o acordo e a síntese" (ibidem, p.196). Ao analisar a abordagem fenomenológica de Ayfre, Andrew retoma seus ensaios sobre o neorrealimo no cinema e o define, tanto em Ayfre como em Bazin, como "o realismo humano que ilustrou com sua própria técnica o incessante diálogo do homem com a realidade física”. Enquanto os semiólogos tendem a um cinema de significado, a fenomenologia - definida inicialmente

\footnotetext{
${ }^{13}$ Imagem, diálogos, ruídos, música, materiais escritos por Christian Metz (1980) ou sonoridades, ritmos, cores, temporalidades por Andréa França (2003).
} 
por Edmund Husserl (1990) como uma investigação dos fenômenos da consciência e seus objetos - deixaria transparecer um sentido para além de um discurso organizado, algo que apareceria espontaneamente do próprio objeto.

Este trabalho não pretende confrontar semiologia e fenomenologia, apenas procura encontrar um entendimento de cinema de ficção que não se reduza a um modelo representacional e a uma realidade imutável, mas que leve em conta a comunicação entre imagens, sons e público, deixando transparecer dispositivos variados que traçam caminhos autônomos. Para Andrew, semiologia e fenomenologia se aproximam quando a interpretação dos signos de um filme passa a se dar na dimensão subjetiva de cada espectador, levando em conta o diálogo entre o mundo criado pelo filme e o mundo vivido o qual o filme faz referência.

\begin{abstract}
Os semióticos devem perseguir a tarefa de desenvolver uma ciência do cinema de modo que possam entender as condições e processos através dos quais todos os filmes funcionam. Mas a fenomenologia desejaria ir além disso e investigar os momentos nos quais a linguagem de signos do cinema se torna outro tipo de signo, com o qual o atomismo da semiótica não pode lidar (ibidem, p. 201).
\end{abstract}

O filme não é um refúgio ou ilusão distanciada da realidade, é sim um produto formal da imaginação que organiza nossa percepção e comportamento, gerando outras ideias e imagens. A noção de mundo se dá em relação ao termo diegese que designa o mundo fictício proposto pelo filme e erigido imaginativamente. A ficção tem a capacidade de criar mundos autônomos alicerçados em acordos traçados entre filme e público, entretanto a percepção e o entendimento desses mundos se dão, não apenas como respostas a essas convenções mas, principalmente a partir de suas instâncias narrativas. "Deixar-se absorver ou envolver por uma ficção significa concentrar-se nos personagens, objetos e acontecimentos do mundo" diz Murray Smith (ibidem, p.161). É a organização desses elementos que provoca um forte apelo ilusório, levando o espectador a conceber mundos completos, autônomos e diferenciados. Lembrando do belo livro de Jean-Claude Carrière, A linguagem secreta do cinema:

$\mathrm{E}$, finalmente, nunca nos esqueçamos de que a linguagem, de qualquer espécie que seja, é, inerentemente, ilusória. Há muito tempo, os poetas já perceberam isso [...]. E, ainda assim, quando um filme nos toma por completo, as imagens que sabemos falsas podem nos levar a uma realidade superior, mais forte, mais penetrante, e decisivamente mais real do que a própria realidade" (CARRIÈRE, 1995, p. 219-220). 


\title{
1.2. Narrativa cinematográfica e gênero cotidiano
}

\author{
Roland Barthes começa seu texto Análise Estrutural da Narrativa (2011)
} enumerando a imensa diversidade de narrativas existentes: fábulas, contos, novelas, cinema, quadrinhos, etc. A narrativa começa no passado, com a própria história da humanidade, e permanece no presente em diferentes lugares, sociedades, povos, constituindo uma atividade essencial do homem. Tal universalidade justificaria sua significância e o interesse do autor em fundamentá-la.

Inumeráveis são as narrativas do mundo. Há, em primeiro lugar, uma variedade prodigiosa de gêneros distribuídos entre substâncias diferentes, como se toda matéria fosse boa para que o homem lhe confiasse suas narrativas: a narrativa pode ser sustentada pela linguagem articulada, oral ou escrita, pela imagem, fixa ou móvel, pelo gesto ou pela mistura ordenada de todas estas substâncias; está presente no mito, na lenda, na fábula, no conto, na novela, na epopeia, na história, na tragédia, no drama, na comédia, na pantomima, na pintura (recorde-se a Santa Úrsula de Carpaccio), no vitral, no cinema, nas histórias em quadrinhos, no, na conversação. Além disto, sob estas formas quase infinitas, a narrativa está presente em todos os tempos, em todos os lugares, em todas as sociedades; a narrativa começa com a própria história da humanidade; não há em parte alguma, povo algum sem narrativa; todas as classes, todos os grupos humanos têm suas narrativas, e frequentemente estas narrativas são apreciadas em comum por homens de culturas diferentes, e mesmo opostas; a narrativa ridiculariza a boa e a má literatura: internacional, trans-histórica; transcultural; a narrativa está aí, como a vida (ibidem, p.19).

Preocupado em modos de construção narrativa e em seus diversos níveis de análise, Barthes articula narrativa e elementos que a estruturam. As inúmeras narrativas e a multiplicidade de pontos de vista pelos quais é possível abordá-las o instigam a traçar, no meio da desordem, um caminho organizacional para pensá-las enquanto discurso. Seu modelo ressalta, ao mesmo tempo, a importância de seus diferentes elementos internos e a possibilidade de entrarem em correlação com os demais. Em uma narrativa, nenhum elemento pode ser tomado como insignificante, tudo faz sentido, como em um princípio de solidariedade, em que cada um entra em relação com os outros e colabora na construção do todo.

O esforço de Roland Barthes em organizar um campo narratológico se conduz no sentido de encontrar um caminho metodológico para distinguir em uma narrativa os seus conteúdos manifestos, estratégias e funcionalidades. Em seu método, distingue classes de unidades narrativas que se diferenciam em sua natureza: as funções e os índices. As 
funções remetem a "funcionalidade do fazer" e são fundamentais para dar andamento à história, para provocar uma ação subsequente ou para separar momentos importantes da narrativa; enquanto os índices se relacionam à "funcionalidade de ser" e trabalham no nível dos personagens ou da narração. Os índices são elementos da narrativa que não objetivam o desenvolvimento da trama, mas seu enriquecimento, ajudando a criar sua atmosfera, a caracterizar ambientes e personagens ou a estabelecer uma localização no tempo e no espaço. Em sua análise, Barthes também examina a narrativa ao nível das ações e dos personagens, buscando em autores como Aristóteles e Julien Greimas modos de relacioná-los, seja tendo o personagem como agente de sua ação, seja como elemento subordinado aos acontecimentos. A estruturação em funcionalidades do fazer e do ser se justificam na intenção de definir os personagens de uma narrativa ora pelo que praticam, ora sujeitos a uma caracterização física e psicológica.

Esta tese não pretende realizar uma análise estrutural de elementos narrativos, muito menos traçar uma lógica dos acontecimentos presentes em um filme, apenas abre um diálogo para pensar a relação entre personagem e espaço em narrativas cinematográficas. A dualidade proposta em dimensões do fazer e do ser aparece no sentido de estruturar futuras análises de modos de habitar que se edificam entre as ações (práticas) realizadas pelos personagens e a apropriação dos ambientes por essas práticas. Filmes de ficção são histórias com começo, meio e fim - "todo filme tem um último plano", dizem Gaudreault e Jost (2009, p. 32) -, mas são também narrativas construídas em materialidades. A pesquisa em questão leva em conta essas duas premissas, considerando, ainda, o potencial de imaginação e percepção de imagens e sons diante de um espectador (ou pesquisador). A pretensão não é se fechar em um modelo de organização sujeito a códigos de leitura e significados, mas se conduzir em modos de se experienciar as diversas narrativas cinematográficas no que um filme gera de subjetividades.

A narratologia ${ }^{14}$ como abordagem teórico-metodológica se valoriza diante de estudos voltados para elementos constituintes de uma narrativa (personagem, ação, espaço, tempo), graças aos quais o espectador do cinema pode ter acesso ao mundo ficcional proposto em um filme. Para fins desta pesquisa, destaca-se um elemento constituinte da narrativa cinematográfica - o espaço - à luz de suas especificidades, bem

\footnotetext{
${ }^{14}$ O termo "narratologia" é uma tradução do termo francês "narratologie" introduzido por Tzyetan Todorov em sua "Gramática do Décaméron" (1969), definido como "a ciência da narração". Enquanto teoria, pertence às abordagens estruturais que consideram as narrativas regidas por regras e códigos comuns, tendendo a analisar seus componentes e o modo como se articulam entre si.
} 
como diante de suas afinidades compartilhadas com personagens e suas ações, e do mesmo modo, em correlação com o filme como um todo. $\mathrm{O}$ intuito é compreender um modo representaciona $1{ }^{15}$ desse elemento no que tange às transformações vividas pela sociedade contemporânea, isto é, encontrar novas modalidades narrativas para se constituir espaços fílmicos, formas de como narrar o mundo percebido hoje em relação à nossa cultura e à própria linguagem cinematográfica.

Para tanto, o presente estudo se desprende dos enfoques estruturais de Roland Barthes e se aproxima das abordagens narratológicas de André Gardies (1993a) e André Gaudreault (2009), que procuram pensar a narrativa do cinema em suas distinções e singularidades. De modo diverso à semiologia do cinema proposta por Christian Metz, uma espécie de adaptação da narratologia literária para o cinema, Gardies e Gaudreault colocam no centro de suas pesquisas a narrativa cinematográfica no que ela se oferece para narrar uma história em imagens e sons.

Com André Gardies, indaga-se, primeiro, se “"narrativa' e 'fílmico' devem ser tratados igualmente ou se convém privilegiar um dos dois?"16 (1993a, p.8).

A narrativa fílmica não é narrativa colocada em imagens e sons, mas imagens e sons agenciados de modo a produzir narrativa. Se trata então de analisar em que a linguagem e a expressão cinematográfica são suscetíveis de produzir narração e não de considerar o filme como um conjunto de respostas audiovisuais a questões narrativas ${ }^{17}$ (ibidem, p.11).

A abordagem proposta se assemelha à noção de narrativa apresentada pelo pesquisador André Parente ${ }^{18}$ : “é uma função pela qual é criado o que nós contamos e tudo o que é preciso para contá-la, ou seja, seus componentes enunciados, imagens, personagens, etc. [...] ela não conta a história dos personagens e das coisas, ela conta os personagens e as coisas" (PARENTE, 2004, p.259). Se em sua definição, Parente valoriza os componentes narrativos, afirmando que são os enunciados, as imagens que constroem

\footnotetext{
${ }^{15}$ Como já foi explicitado anteriormente, não uma representação voltada para a busca de significados, mas sim de possíveis sentidos que se desprendem da materialidade fílmica em um diálogo permanente com o real.

16 “"Récit' et 'filmique' doivent-ils être traités également ou convient-il de privilégier l'un des deux?". N.T.

17 'Le récit filmique ce n'est donc pas du récit mis en images et sons, mais des images et des sons agencés de façon à produire du récit. Il s'agit alors d'analyser en quoi le langage et l'expression cinématographiques sont susceptibles de produire de la narration et non d'envisager le film comme un ensemble de réponses audiovisuelles à des questions narratives". N.T.

${ }^{18}$ Inspirada da definição proposta pelo escritor e ensaísta francês Maurice Blanchot "a narrativa não é o relato do acontecimento, mas o próprio acontecimento, a aproximação deste acontecimento, o lugar onde este é chamado a produzir-se, acontecimento ainda por vir e por cuja atração a narrativa pode esperar, também ela, realizar-se" (2005, p.8).
} 
a realidade fictícia, no entendimento de André Gardies, o cinema primeiro mostra, “dá a ver", em seguida ele conta os acontecimentos, assim a narrativa é subordinada à imagem, e não o inverso.

Do mesmo modo, André Gaudreault, juntamente com o teórico François Jost (2009), define narrativa como um modo de narrar ${ }^{19}$ a partir de suas formas de expressão, suas temporalidades e espacialidades, seus pontos de vista, o que os autores denominam de "narratologia da expressão". Quando se fala em narrativa cinematográfica, ambos autores ressaltam a pluralidade e heterogeneidade de suas matérias de expressão, bem como o ponto de vista oferecido pela câmera de filmagem (incluindo aqui o enquadramento, ângulo da tomada, movimento da câmera, etc.) e pela montagem, que acabam por intervir na percepção do espectador diante do que está sendo mostrado. A narrativa cinematográfica lida, então, com uma infinidade de elementos específicos do meio, desde aspectos visuais como a iluminação, a composição da cena, as texturas e cores dos objetos, sua linguagem, os movimentos de câmera, o ritmo das imagens, o som, e a própria história que está sendo contada.

Da complexidade que envolve uma obra cinematográfica à organização dos acontecimentos narrados e suas materialidades, e levando em consideração que os objetos empíricos utilizados para fins desta pesquisa são filmes de ficção de diferentes nacionalidades inseridos em um contexto de imaginário coletivo em um diálogo permanente com a realidade contemporânea, este trabalho reconhece narrativas que exploram temáticas do cotidiano, apontando para seu potencial expressivo diante das problemáticas do mundo urbano atual: a falta de moradia, o desemprego, os dramas familiares, confusões entre vizinhos, entre outros. Assim, o encontro com um gênero do cotidiano manifesta-se como um caminho para apreender filmes de ficção que evidenciam certos elementos narrativos (espaço e personagem) retratados em experiências cotidianas da contemporaneidade, se dedicando a perceber a vida diária, suas práticas, seus lugares e a recriá-los em imagens ficcionais.

O teórico da literatura Mikhail Bakhtin desloca o conceito de gênero de categorias formais literárias para introduzi-lo no domínio das diferentes esferas da comunicação social: "cada esfera de utilização da língua elabora seus tipos relativamente estáveis de enunciados, sendo isso que denominamos gêneros do discurso" (1997, p. 279). Em seu entendimento, os gêneros refletem características regulares estruturadas a partir de

19 Em oposição ao termo história que "é a sequência cronológica dos acontecimentos narrados" (GAUDREAULT; JOST, 2009, p.50). 
aspectos como conteúdo (tema), estilo e construção composicional resultando em tipos relativamente estáveis passíveis de flexibilização, que se diferenciam e se ampliam à medida que se desenvolvem sócio historicamente.

A riqueza e a variedade dos gêneros do discurso são infinitas, pois a variedade virtual da atividade humana é inesgotável, e cada esfera dessa atividade comporta um repertório de gêneros do discurso que vai diferenciando-se e ampliando-se à medida que a própria esfera se desenvolve e fica mais complexa (BAKHTIN, 1997, p.279).

O agrupamento de filmes em um determinado gênero no campo do cinema propõe o reconhecimento de certos padrões de regularidade e caracteres comuns de temática, da narrativa, de estilo, entre outros. No cinema clássico de Hollywood, os gêneros eram bem delimitados, sujeitos a modos de produção industrial e comercial, e a padrões aplicáveis e de fácil reconhecimento no contato com o público. O western, o musical ou a comédia seguiam fórmulas instituídas previamente, comportando cenas obrigatórias, cenários específicos, personagens repetitivos. Ao longo dos anos, e em outras culturas, os gêneros sofreram desdobramentos e foram se distanciando de classificações rígidas, admitindo certa liberdade e fluidez em suas realizações.

A investigação sobre gêneros foi retomada no âmbito do cinema pelo filósofo americano Stanley Cavell $(1993,2008)$ em suas análises sobre as "comédias de matrimônio" e o melodrama, na tentativa de encontrar pontos comuns que se desprendem desse tipo de filme sob um outro ponto de vista. Para além das características aparentes, facilmente reconhecíveis em um gênero cinematográfico, Cavell vasculha as comédias de enredo matrimonial hollywoodianas para se indagar sobre seu retorno emocional e suas implicações filosóficas. Como a filosofia, o cinema tem muito a dizer sobre nossa existência. Através do estudo de gênero, Stanley Cavell se indaga sobre a relação do cinema com "as coisas do mundo", argumentando que o relevante em um filme é sua dependência com a realidade e a transformação que ele pode proporcionar à vida cotidiana.

$\mathrm{Na}$ minha opinião, uma visão natural do cinema consiste em sua capacidade para perceber cada movimento, cada posição e, em especial, cada postura e cada gesto humano, por fugidios que sejam, como carregados de sua poesia, ou bem, poderíamos dizer, de sua lucidez" (CAVELL, 2008, p.40). 
A inserção de um filme em um tipo de gênero facilita a coerência das diferentes materialidades que dispõe em prol de uma única narrativa, além de criar um diálogo com demais filmes que se servem de elementos semelhantes. O filósofo reconhece que as "comédias de enredo matrimonial" questionam a propósito do relacionamento a dois, da igualdade entre o homem e a mulher, das oportunidades de suplantar as dificuldades da vida comum. Desse modo, encontrar filmes que se reconheçam em um gênero do cotidiano, mais do que reconhecer alguns elementos narrativos semelhantes nesses filmes, propicia ao cinema "contribuir para a educação e a inteligência de uma cultura, ou, digamos, para a compreensão que uma cultura tem de si mesma" (CAVELL, 2008, p.15).

Da existência de um possível gênero para representar o cotidiano, a pesquisadora Margaret Cohen se interroga, em seu artigo “A literatura panorâmica e a invenção dos gêneros cotidianos": "um gênero que faz parte da experiência do dia-a-dia com mínimas pretensões estéticas transcendentes" (COHEN, 2001, p.316). Segundo Cohen, na modernidade, o cotidiano foi reconhecido como objeto válido de investigação científica e como gênero de representação para descrever a vida diária dos habitantes da cidade. As práticas da vida cotidiana parisiense da época eram registradas em textos e desenhos que descreviam atos do dia-a-dia, acompanhados de comentários e pequenos detalhes, com a finalidade de "oferecer uma visão geral objetiva dos fenômenos que constituem a experiência cotidiana" (ibidem, p.321). Os textos eram variados e de diversos autores, o que proporcionava aspectos da realidade parisiense, muitas vezes até divergentes. Além da literatura, Cohen investigou os primeiros curtas-metragens como uma continuidade dos registros literários parisienses: "os gêneros do cotidiano e o cinema do século XIX são consequência das práticas que estruturam o cotidiano moderno" (ibidem, p.341). O registro filmado de atividades diárias definiu o gênero cotidiano como uma forma popular de espetáculo, revelando um verdadeiro fascínio do cinema pela vida cotidiana.

Desde seu nascimento, no fim do século XIX, o cinema vem retratando cenas domésticas e a vida cotidiana em suas imagens, evidenciando o encantamento de cineastas em retratar a existência ordinária. Os primeiros filmes dos irmãos Lumière, produtos de um dispositivo técnico precário (câmeras pesadas, ausência de som, película em preto e branco), exibem pessoas comuns e suas práticas diárias: um jardineiro molha suas plantas, uma família faz sua refeição à mesa, funcionários terminam mais uma jornada de trabalho. São apenas registros diários espacializados em ambientes diversos: uma usina, um jardim, uma rua, uma casa. O cotidiano na cidade, seus trânsitos, o ir e vir de seus habitantes, mas também as pequenas mobilidades domésticas e os ínfimos objetos estão presentes nessas 
imagens documentais registradas de modo mais natural possível. Seus títulos, Saída da fábrica Lumière a Lyon, Chegada de um comboio à estação de Ciotat, O almoço do bebê, entregam momentos singulares que poderiam fazer parte de uma só vida: a vida cotidiana.

Com preocupação semelhante em retratar a realidade, e após cinquenta anos de progresso técnico de seu dispositivo (câmeras mais leves, películas mais sensíveis, som e imagem sincronizados), o cinema neorrealista se aproximou de personagens, temas e paisagens presentes na realidade italiana pós-guerra para manifestar um discurso crítico diante do momento presente vivido em seu país. Ainda que se trate de filmes ficção, as narrativas são retratos da realidade de uma época em diferentes dimensões da vida cotidiana: os problemas sociais no campo, o desemprego na cidade, a condição de jovens, velhos e mulheres, a guerra, a relação do homem com a religião. Em suas características técnicas e estilísticas, numa suposta neutralidade ${ }^{20}$ de estilo, como por exemplo a recusa de efeitos visuais e de montagem, a filmagem em cenários reais, a utilização de atores não profissionais, a simplicidade de diálogos, entre outros (FABRIS, 2012, p. 203), esse cinema seguiu uma orientação estética fundamentada na naturalidade e no sentido do comum, chamando atenção para as obras em si mesmas e para a pluralidade da vida a qual faziam referência.

Em perspectiva semelhante, destaca-se o movimento cinematográfico Nouvelle Vague que eclodiu na França no fim dos anos cinquenta. Mais do que um discurso político, sua estética é fruto de circunstâncias econômicas de jovens realizadores que produziam, na época, seus primeiros filmes. A simplicidade de suas produções (equipe mínima, ausência de celebridades e filmagens na rua), como consequência dos baixos orçamentos investidos nos filmes, exibia histórias em torno dos questionamentos e vivências cotidianas da juventude local. Em seus filmes, retratos de seus hábitos e costumes, suas angústias e atitudes.

Se por um lado, alguns movimentos cinematográficos vieram, ao longo dos anos, se ocupando em retratar a vida cotidiana em imagens e sons, de outro, cineastas de diferentes nacionalidades colocaram em cena histórias triviais e personagens comuns, criando retratos coloquiais de seu tempo e se indagando sobre constantes elos entre o cinema de ficção e a realidade. Para o diretor francês Jacques Tati (1907-1982), o cotidiano se evidencia de modo cômico na dinâmica da sociedade moderna; com o diretor Yasujiro Ozu (1903-1963), os dramas familiares japoneses se revelam em diálogos

\footnotetext{
${ }^{20}$ Pode-se relacionar a neutralidade de estilo à noção de "grau zero de escrita" de Roland Barthes (2004).
} 
casuais, gestos comuns, movimentos repetitivos, refletindo as complexidades da condição humana na vida do dia-a-dia; os chineses Hou Hsiao-hsien (1947) e Edward Yang (19472007) apreendem o cotidiano em imagens prolongadas, ações que se sucedem e desventuras minimalistas; enquanto para o diretor iraniano Abbas Kiarostami (1940), a imagem do real se dá na ambiguidade dos pequenos acontecimentos e nas incertezas cotidianas.

Um desempregado e seu filho procuram pelas ruas da cidade sua bicicleta roubada, uma família se reúne em uma festa de casamento, um casal de idosos se prepara para uma viagem de reencontro com os filhos, um rapaz apaixonado quer se declarar, acontecimentos banais que esses cineastas insistem em nos mostrar. Mas o que poderia interessar em cenas tão ordinárias? Como essas narrativas cotidianas nos sensibilizam, exibindo lugares e pessoas tão comuns, enquanto em nosso cotidiano os vivenciamos com tanta indiferença? O filósofo Alain de Botton (2012) escreveu um livro chamado A arte de viajar, propondo uma concepção de viagem que torna sensível o desinteressante. A obra é uma espécie de guia de viagem inusitado, onde o autor sugere a visita a alguns lugares sob o ponto de vista de escritores, pintores e poetas: a Provença sob o olhar de Vincent Van Gogh; o posto de gasolina, o aeroporto e o trem na visão de Charles Baudelaire e Edward Hopper; e ao final, o bairro londrino Hammersmith na proposta de Xavier de Maistre. De Maistre viveu na França no século XVIII e sonhava em viajar. Com poucos recursos acabou inventando uma modalidade de viagem que provocou sua notoriedade: "viagem ao redor do quarto".

A história começa bem. De Maistre tranca a porta e se mete em seu pijama azul e cor-de-rosa. Sem precisar de bagagem, viaja até o sofá, o maior móvel do quarto. Tendo assim sacudido sua letargia habitual, ele o contempla com novos olhos e redescobre algumas qualidades. (BOTTON, ibidem, p. 237).

Alain de Botton toma como exemplo a viagem de Xavier De Maistre em seu universo cotidiano para fazer a sua viagem ao redor do bairro onde mora em Londres. Ao percorrer seu espaço cotidiano com um olhar de viajante, o filósofo descobre coisas novas que passavam desapercebidas em sua correria diária. A viagem em torno de um espaço banal e familiar feita de modo mais atento acaba revelando certos encantos desconhecidos até então. "A vizinhança não ganhou apenas pessoas e prédios mais definidos, passando também a reunir ideias. Pensei na nova riqueza que se espalhava na região" (ibidem, p.243), diz ele. 
Se um escritor-viajante procura um algo mais na banalidade diária, um poeta pode encontrar densidade nas coisas simples da vida. O crítico literário Davi Arrigucci Júnior (1987), analisando as obras de Manuel Bandeira reconhece que o cotidiano "se mostra como o espaço propício a uma busca poética que deseja fazer alguma coisa simples, honrada e bela. Ali se pode compreender como o mais humilde, o muito pequeno constitui, na verdade, a vida" (ibidem, p.38). No ensaio que faz do poema Maçã ${ }^{21}$, reconhece a simplicidade das coisas cotidianas engrandecidas pelos versos de Manuel Bandeira. O acanhado fruto vermelho evoca a mãe-terra, os versos improvisam uma natureza-morta, o quarto se desprende em "reduto da interioridade do sujeito: espaço lírico por excelência, onde se recolhem as impressões da realidade e se gera a poesia" (ibidem, p.23).

De Maistre e Bandeira transmutam domesticidade em encantamento; escritor e poeta veem através, com um olhar atento ao cotidiano, comungam a fragilidade da vida em suas diversas nuances. Para além de um mundo de banalidades, o cotidiano retoma seu potencial expressivo e ensina uma lição: "atingir o máximo de matizes com o mínimo de elementos, como quem tira muito de pouco" (ibidem, p.39). Qualquer elemento é levado em consideração, ainda que visivelmente avaliado de menor importância. Aqui, voltamos ao conceito de "estética da transparência", porém, agora amparado em sua sua origem etimológica: do latim, transparentia significa "deixar ver através de". Para além do conjunto de técnicas e procedimentos de seu dispositivo, um filme narra uma história com pretensões para um algo mais que se quer fazer notar. $\mathrm{O}$ gênero do cotidiano no cinema deixa ver através da aparência de cenas banais e corriqueiras toda complexidade e plenitude da existência humana, como idealizado pelo filósofo Stanley Cavell.

A finalidade desta tese não é encontrar filmes que propõem novos modelos narrativos em hibridações de gêneros, interatividades múltiplas entre obra e público ou alterações tecnológicas de linguagem. A busca por modelos narrativos se faz, aqui, no âmago constitutivo da narrativa, em suas unidades menores: o espaço e o personagem. A "transparência" é retomada, chamando atenção para a obra em si mesma e para o seu interior. Nesse sentido, as narrativas cinematográficas do cotidiano abrem-se em visibilidades, isto é, no espaço pró-fílmico manifesto, não objetivam camuflar os resíduos do dispositivo cinema para iludir ou entorpecer seus espectadores, tensionam reconduzir

\footnotetext{
21 "Por um lado te vejo como um seio murcho/Pelo outro como um ventre de cujo umbigo pende ainda o cordão placentário/ És vermelha como o amor divino/Dentro de ti em pequenas pevides/ Palpita a vida prodigiosa/infinitamente/ E quedas tão simples/ Ao lado de um talher/ Num quarto pobre de hotel".
} 
sua atenção para o que existe além da aparente trivialidade, como Xavier De Maistre em sua viagem ao redor do quarto ou como Manuel Bandeira em sua poesia de um quarto pobre de hotel. A narrativa cotidiana é o que consente que um quarto e uma maçã passem da superficialidade à densidade; torna um lugar mais acessível, personagens mais convincentes, ações mais reflexivas. A matéria esculpida deixa de ser o filme em seus aspectos técnicos, e passa a ser o mundo ficcionalizado com tudo que ele devolve a nossa existência. O cinema do cotidiano é diferente da vida diária porque nele temos tempo; cheio de detalhes e lembranças à mostra, nos conduz de volta à vida de todo dia, deixa seu "leitor" ler nas entrelinhas, em imagens e sons, em percepções e imaginação.

\subsection{O homem cosmopolita no cinema mundial contemporâneo}

No artigo Baraka: o cinema mundial e a indústria cultura global, o pesquisador Martin Roberts (2010, p.17-42) posiciona a noção de "cinema mundial” na fronteira com o "cinema global", investigando um longa-metragem filmado em vinte e quatro países que apresenta um retrato global dos povos do mundo todo. A dimensão transnacional da produção de filmes atuais, bem como o impacto da globalização nos conteúdos dos filmes são questões levantadas para delinear uma categoria analítica que, a princípio, incluiria todo tipo de filme.

Como vimos a pouco, o termo é mais frequentemente utilizado para significar "a indústria de cinema global", em vez do sentido mais restrito, que uso neste texto, de filmes que explicitamente se inserem em um discurso sobre algo chamado "mundo". À parte das implicações ideológicas de um termo tão globalizante, poderíamos querer nos informar sobre a utilidade analítica de uma categoria conceitual que na esfera da produção cinematográfica, pelo menos - inclui potencialmente tudo (ibidem, p.40).

Ainda que muitas indústrias cinematográficas conservem seu caráter nacional, os

filmes com múltiplas nacionalidades, de coproduções e distribuições internacionais proliferam em todo canto, o acesso e o consumo de narrativas de comunidades distantes ou periféricas aumentam sensivelmente na maioria das cidades. Neste contexto da dinâmica da globalização, Roberts avalia o papel do cinema mundial como articulador e propagador dos discursos ideológicos sobre o mundo. Atualmente, cresce o número de narrativas cinematográficas que exploram temáticas como nomadismo, migração, 
fronteira, hibridismo, apreendendo um imaginário global que pensa o cinema e sua relação com a realidade contemporânea.

Ao mesmo tempo em que os filmes em questão pertencem a cinemas nacionais diferentes, a gêneros de filmes diferentes e dirigem-se a públicos diferentes, eles compartilham uma preocupação com a globalização, com as novas formações culturais da ordem mundial póscolonial, e se esforçam para enquadra-las em uma visão totalizante do "mundo" (ibidem, p.20).

A categoria cinema mundial se relaciona com a problemática da interculturalidade, inspirando questionamentos sobre o indivíduo e suas subjetividades, ao mesmo tempo em que considera a diversidade cultural da era globalizada. Hudson Moura (2010, p.43-66) pesquisa a noção de intercultural no cinema, afirmando que nosso tempo é a época das pessoas em movimento, o que tem levado artistas e intelectuais a expressarem a temática em suas manifestações criativas. O pesquisador aponta para denominações que se desprendem do cinema intercultural, como cinema multicultural, transnacional, híbrido, cinema emergente, minoritário, para dar conta das experiências das mobilidades humanas dos últimos tempos: "o cinema intercultural questiona o pertencimento a uma cultura, a uma comunidade, ao cinema contemporâneo, e, através da intermidialidade, o pertencimento a uma só mídia e ao sujeito da modernidade" (ibidem, p.44). Associado à noção de interculturalidade, o cinema mundial define um cinema que se ocupa em colocar na tela a degradação da condição humana e os movimentos migratórios posicionados em embates constantes entre discursos heterogêneos de culturas diversas.

Ao mesmo tempo, com o intuito de repensar a interculturalidade e a porosidade das fronteiras nos processos globais, Néstor Garcia Canclini propõe o conceito de hibridez como possibilidade de cruzamentos interculturais que se dão na dinâmica de um mundo "fluidamente interconectado". Para ele, "as migrações, as fronteiras permeáveis e as viagens falam, em seus estranhamentos, daquilo que a globalização tem de fratura e segregação. Também por isso irrompem narrativas e metáforas nos relatos de migrantes e exilados" (CANCLINI, 2007, p.9). O papel da cultura é questionar a globalização como realidade factual e como modelo de processos de homogeneização e supressão das desigualdades, se colocando como transformadora na reordenação das diferenças entre culturas. No cinema mundial, as múltiplas narrativas dispõem os conflitos de imaginários da globalização, sugerindo modos de repensar o global e o local, posicionando o cinema 
e suas obras como parte de um potencial imaginativo capaz de oferecer diversidade nos modos de se conceber e representar o mundo.

O embate entre culturas é, também, tema de Andréa França (2003) que procura pensar o conceito de nação e fronteira, a partir do cinema político contemporâneo. Para França, o cinema se coloca como imagem do mundo capaz de criar novas "comunidades imaginadas, distintas e variáveis" frente às mudanças de deslocamento e fluxos migratórios da atualidade.

Com o declínio das fronteiras nacionais, a intensificação em massa e o aumento do fluxo de narrativas e imagens, a ideia de nação/etnia passa a ser construída e reconstruída dentro de uma nova lógica, onde a evidência das fronteiras nacionais, demarcadora de cinematografias, é substituída pelas co-produções transnacionais, por uma massa de espectadores e imagens desterritorializados. (FRANÇA, 2003, p. 26).

Interessada "naquilo que faz do cinema recente uma espécie de testemunho das imagens do mundo" (ibidem, p.17), a pesquisadora prefere se afastar do conceito de representação para dar conta do modo como certos filmes veem a questão da globalização ${ }^{22}$ e imaginam novas cartografias que se desprendem de modo "singular em sua materialidade sensível", em sentidos e visibilidades. Seu propósito é atentar para as preocupações geográficas contemporâneas, mediando nossa relação com o mundo e com as expressões que fazemos a partir dele.

As narrativas cinematográficas de ficção pesquisadas como base para esta pesquisa pertencem à categoria cinema mundial amplificada pela noção de globalização e interculturalidade. Nesse contexto, o cinema tem apontado para reflexões estéticas, políticas, sociais, concernentes às experiências de deslocamento, despertencimento, segregação, compartilhando inquietações com as novas formações culturais do cenário contemporâneo. Seus filmes constituem imaginários alicerçados em uma observação de mundo cada vez mais global, levando em consideração as questões culturais apreendidas também localmente. Entende-se que a globalização impacta no conteúdo dos filmes em todo o mundo, pressupondo novos modelos narrativos para dar conta dos processos contemporâneos e suas novas geografias; e, concomitantemente, as obras cinematográficas propõem novos sentidos para repensar a globalização e seus processos, criando universos autônomos e novas experiências de mobilidade.

\footnotetext{
${ }^{22}$ Em suas análises, Andréa França opta pelo conceito de internacionalização, no lugar de globalização, para pensar a diluição de fronteiras e o surgimento de outras.
} 
Uma variedade de filmes do cinema mundial tem se apoiado em experiências urbanas para traçar suas narrativas, oferecendo diferentes imagens das cidades, seus fluxos de circulação e problemáticas contemporâneas. Diante dessa ampla e diversa filmografia, o estudo em questão se centraliza em filmes do cotidiano, apreendido enquanto um possível gênero cinematográfico que se ergue sobre as coisas mundanas, o indivíduo e suas subjetividades: suas imagens e sons se apoiam em um modo narrativo característico que expõe práticas diárias, ações rotineiras que se sucedem e se repetem todo santo dia, como morar, comer, dormir, trabalhar; seus enredos desenham a sociedade que vivemos a partir da escala humana, próxima às pequenas questões mundanas, aflições costumeiras, sobrevivências diárias, dramas familiares, solidão, brigas entre vizinhos, afetos incompreendidos; seus protagonistas são personagens comuns, uma mulher desempregada, um vendedor argentino, uma jovem recém-formada, um estrangeiro chinês, um pai e uma filha desamparados; seus espaços são lugares habituais e familiares como uma casa, uma escola, um bairro, os espaços da intimidade, dos laços afetivos mas também os lugares de trânsito da vida diária, as ruas, os transportes públicos, os aeroportos, os hotéis, as estradas. A dimensão do cotidiano está incorporada nas temáticas e situações, nos personagens e em suas práticas, nos lugares percorridos e apropriados por esses personagens, definindo as instâncias narrativas do gênero.

Essas premissas foram determinadas, em um primeiro momento, em reflexão à teoria das práticas cotidianas do sociólogo Michel de Certeau. O pensador francês nos ensina que:

O cotidiano é aquilo que nos é dado cada dia (ou que nos cabe em partilha), nos pressiona dia após dia, nos oprime, pois existe uma opressão do presente. Todo dia, pela manhã, aquilo que assumimos, ao despertar, é o peso da vida, a dificuldade de viver, ou de viver nesta ou noutra condição, com esta fadiga, com este desejo. O cotidiano é aquilo que nos prende intimamente a partir do interior. É uma história a meio caminho de nós mesmos, quase que retirada, às vezes velada (CERTEAU,1996, p.31).

Sua obra A invenção do cotidiano $(1994,2009)$ é dedicada ao "homem ordinário", herói comum, também denominado "cada um (nome que trai a ausência de nome), este anti-herói é também Ninguém [...]. É sempre o outro, sem responsabilidades próprias [...] e de propriedades particulares que limitam o lugar próprio" (ibidem, p. 58). Essa definição dialoga com as categorias do comum e do banal, instalando a presença de um homem ${ }^{23}$

\footnotetext{
${ }^{23}$ Ordinário no sentido de comum. E não de medíocre, inferior ou sem caráter.
} 
ordinário e de um destino comum. Os projetores de cinema abandonaram os personagens donos de nomes próprios e de 'brasões sociais' para voltar-se à multidão de figurantes, transeuntes que cruzam a cena quase invisíveis. O homem-comum é o anônimo, ao mesmo tempo “todo mundo e ninguém”. Entendido com base no lugar comum que ocupa, é capaz de reinventar o cotidiano assumindo sua própria existência a partir das "práticas de fazer". Michel de Certeau vislumbra certa autonomia na narrativa de cada um por meio das ações do dia-a-dia. Mediante as práticas cotidianas (caminhar, ler, produzir, falar, etc.), esse anti-herói transcende estereótipos, comportamentos padrões, conformações impostas pela sociedade, abrindo cada um seu próprio caminho.

Segundo Certeau, o homem comum veio, aos poucos, ocupando o centro do ambiente científico. De protagonista das cenas científicas, o sujeito ordinário passa a personagem central das tramas cinematográficas. Se por um lado, o cinema se ocupa em contar as histórias de grandes heróis e seus extraordinários feitos, de outro vem colocando nas telas personagens simplórios conduzidos perante uma existência comum. São os filmes do cotidiano que colocam o homem comum em imagens com tudo que ele possa oferecer de ambiguidade: ora se define de modo genérico como um motorista, um pai, um estrangeiro, uma estudante, um executivo, vivenciando situações semelhantes às de todo mundo, ora tem nome próprio, endereço fixo, e trajetória individual.

$\mathrm{Na}$ filmografia selecionada para a pesquisa, a problemática do cotidiano se dá entre duas dimensões narrativas: uma com referência à "escala humana" e outra com relação à "escala urbana" 24 , isto porque o corpus empírico utilizado para fins desta pesquisa são filmes que exploram trajetórias individuais localizadas em espaços urbanos. No cinema, a escala humana corresponderia ao espaço íntimo do personagem, enquanto a escala urbana se ocuparia em evidenciar o ambiente exterior, o espaço urbano representado nas imagens. Ambas as escalas se complementam. Como habitantes urbanos, a cidade impõe aos personagens situações experienciadas igualmente no âmbito da intimidade. Perceber essas duas dimensões narrativas, a partir de uma filmografia pertencente ao cinema mundial contemporâneo, possibilita apreender o espaço fílmico como um todo, e, ao mesmo tempo, identificar o cotidiano urbano como lugar de referência para personagens comuns afigurados como cidadãos do mundo.

\footnotetext{
${ }^{24}$ Há aqui uma apropriação do termo escala utilizado no âmbito do urbanismo para tratar da dimensão do espaço íntimo do personagem e de sua inserção em um espaço mais amplo de representação, que é a dimensão da cidade onde a narrativa se desenvolve.
} 
Ser urbano é pertencer a um espaço com características próprias, mas também a um tempo, no nosso caso, o tempo contemporâneo. Ao investigar a noção de contemporâneo, Giorgio Agamben recorre a um poema ( $O$ século do russo Osip Mandel'stam). Mais do que questionar uma época, o poema analisado é uma "reflexão sobre a relação entre o poeta e seu tempo, isto é, sobre a contemporaneidade" (2010, p.59). O primeiro verso diz: "Meu século, minha fera, quem poderá/olhar-te dentro dos olhos/e soldar o sangue/as vértebras de dois séculos". Em seus versos, reflete-se o século que se vai e o novo século que começa. Nessa ruptura, o poeta se distancia de um tempo e se apropria de outro. Para Agambem, o "contemporâneo é aquele que mantém fixo o olhar no seu tempo, para nele perceber não as luzes, mas o escuro" (ibidem, p. 62). O escuro não é a ausência de luz, mas implica uma habilidade de enxergar a íntima obscuridade.

O cinema contemporâneo do gênero cotidiano procura manter o olhar fixo em seu tempo, entrevendo o desapercebido de uma vida banal. Suas narrativas permanecem atentas para os grandes temas do mundo urbano contemporâneo, mas suscitam a grandeza no que é ordinário. Entre eles, o filme Transeunte (Eryk Rocha 2010) contrapõe a rotina doméstica de um aposentado e seu deambular solitário pelo centro do Rio de Janeiro; o filme americano Indomável sonhadora (Benh Zeitlin, 2012) expõe personagens humildes que se recusam a deixar suas precárias habitações na periferia de Louisiana para morar na cidade; El limpiador (Adrian Saba, 2012) narra a história de um faxineiro que, diante de uma epidemia devastadora em Lima, encontra um garoto abandonado e o leva para sua casa, ele tenta mantê-los vivo enquanto sua cidade morre lentamente; em $O$ homem ao lado (Mariano Cohn e Gastón Duprat, 2009), a diferença social e econômica na sociedade argentina abre uma janela para a falta de solidariedade entre vizinhos; em Cães errantes, filme de nacionalidade chinesa e francesa (Ming-Liang Tsai, 2013), pai e filhos desempregados ocupam os espaços invisíveis da cidade, buscando sobreviver perante o vazio existencial. Em sociedades segregadoras, há tentativas de inconformismo e de preservação identitária; sob as luzes da cidade, solicita-se o que se esconde no interior da alcova; um cinema que se preocupa mais pelo íntimo do que pelo acontecimento aparente.

Neste ponto, é preciso se perguntar: que cotidiano estão narrando esses filmes que têm fixo o olhar no seu tempo? Em sociedades urbanas, como o cinema contemporâneo mundial vem construindo um imaginário da realidade cotidiana face à globalização? Henri Lefebvre, em seu livro $A$ revolução urbana, analisa uma forma de organização social do espaço constituída na passagem da industrialização à urbanização: 
A grande cidade explodiu, dando lugar a duvidosas excrescências: subúrbios, conjuntos residenciais ou complexos industriais, pequenos aglomerados satélites pouco diferentes de burgos urbanizados. [...] É assim que nossa hipótese impõe-se ao mesmo tempo como ponto de chegada dos acontecimentos adquiridos e como ponto de partida de um novo estudo e de novos projetos: a urbanização completa (LEFEBVRE, 1999, p.17).

A problemática urbana imposta à escala mundial repercute nas tensões da vida contemporânea, prevalecendo sobre as demais, em uma espécie de "revolução urbana". Para Lefebvre, o centro urbano está por toda parte, não mais centralizado em um único ponto de encontro. A sociedade se constitui em múltiplos focos onde pessoas e coisas se reúnem de modo simultâneo, nos espaços circundantes e virtualmente, em um dinamismo facilitador da emancipação e convivência entre diferentes. Há uma implosão-explosão da cidade que, agora, se define como megacidade, metrópole, megalópole. Se as questões mundanas adquirem uma forma eminentemente urbana, refletir sobre o tema do cotidiano passa por indagações como: em que medida essa revolução altera a configuração dos espaços cotidianos construídos nas megacidades? Como se dão as práticas diárias nesses espaços reconfigurados? Que modelo de protagonista ocupa o centro do atual processo de urbanização? E no cinema, como as narrativas ficcionais vêm experimentando as transformações na sociedade contemporânea, articulando temas, situações e suas materialidades? Quais são os novos protagonistas dos filmes de ficção? Como esses protagonistas habitam os espaços nas narrativas fílmicas?

A presente tese vislumbra a hipótese de que, no cinema mundial contemporâneo, evidenciam-se alterações no modelo narrativo do cotidiano: o "homem ordinário" assume o papel de "homem da contemporaneidade", transmutando-se em protagonistacosmopolita. Quando se profere cosmopolita, se expressa basicamente a perspectiva de uma sociedade urbana, de um mundo globalizado, transnacional. A imagem do cosmopolita é cambiante, não se limita a cidadãos do mundo, mas inclui também os imigrantes, os expatriados, os desassistidos, os deslocados, os sem-teto, etc. Os cosmopolitas são aqueles que não têm ponto fixo, se deslocam o tempo todo, ou quase sempre; não têm local certo onde dormir ou dormem precariamente; não moram, se abrigam; invadem lugares e espiam o espaço alheio; suas práticas não têm localidade certa, nem hora certa; não obedecem às regras do lugar; renovam nos modos de fazer, improvisam; amam instantaneamente e intensamente; insatisfeitos, estão sempre à procura, no intervalo entre um ponto e outro. 
Sendo assim, diante da renovação da imagem do homem comum e suas práticas cotidianas, concebendo-o como um protagonista-cosmopolita inserido em um cenário urbano fruto de um imaginário coletivo que pensa a vida contemporânea e suas transformações, e entendendo que há um elo narrativo intrínseco em filmes de ficção entre personagem e espaço, se faz necessário, então, refletir sobre as alterações do gênero cotidiano no nível das dimensões do espaço fílmico. Dos espaços cotidianos representados em um filme, esta pesquisa se atém ao estudo de modos de habitar que se constroem diante da presença desse homem cosmopolita. Se a este protagonista, agregamse instâncias de mobilidade exacerbada pertinentes à contemporaneidade, pressupõemse, do mesmo modo, espaços fílmicos constituídos não apenas com base na narrativa exposta, contudo manifesto em experiências de deslocamentos e transitoriedades que implicam em uma mudança na relação com os modelos narrativos do gênero cotidiano praticados no cinema de ficção.

Entendendo o espaço como elemento fundante da narrativa cinematográfica e como possibilidade para um método de análise de filmes ficcionais, estudos sobre as dimensões espaciais fílmicas se fazem necessários. Dentre os elementos próprios de uma narrativa cinematográfica, a princípio, o espaço aparece como um elemento secundário, sinônimo de cenário e restrito a concepções cenográficas com o intuito de posicionar personagens em um tempo e um lugar determinado, seja uma cidade, uma estrada, ou mesmo uma casa. A questão se torna um pouco mais complexa quando pensamos no espaço como uma circunstância de enunciação específica da narrativa, desenvolvida em torno de contextos e temas explorados a cada filme, envoltos em percepções e imaginações concebidas no encontro com as materialidades fílmicas. Segue-se, então, na investigação do "indefectível espaço fílmico". 


\section{ASPECTOS FORMATIVOS DO ESPAÇO FÍLMICO}

\subsection{O indefectível espaço fílmico}

André Gardies admite que a "imagem em movimento é antes de tudo uma organização móvel de um espaço bidimensional. Sem espaço, nada de cinema. Nesse sentido, ele é o primeiro e não subordinado"25 (1993a, p.69). André Bazin escreve ser possível "esvaziar a imagem cinematográfica de toda realidade, menos uma: a do espaço" (apud CHEVALLIER, 2012, p.277). Do mesmo modo, André Gaudreault e François Jost dizem "ser difícil conceber uma sequência de eventos fílmicos qualquer que não esteja, sempre, inscrita em um espaço singular. A unidade básica da narrativa cinematográfica, a imagem, é um significante eminentemente espacial" (2009, p.105). Philippe Chevallier afirma que o "espaço não é uma dimensão da imagem entre as outras (como o som ou a luz), mas algo sem o qual a imagem cinematográfica não seria mais ela mesma, sem o qual nada tomaria forma diante de nossos olhos"26 (2012, p.277).

Enquanto a relação intrínseca entre cinema e espaço parece ser consensual entre pesquisadores, as diversas abordagens estéticas propostas para analisá-lo apontam para sua complexidade:

[...] o espaço é ambíguo, polivalente, dependente ao mesmo tempo da sensibilidade visual - ou visionária - do cineasta, da ideologia circundante, das realidades socioeconômicas de uma época, etc. É preciso, em nossa opinião, reconhecer nele uma bipolaridade que condensa todas as somas possíveis de antagonismos contraditórios ${ }^{27}$ (AGEL, 1978, p.28).

Nos primórdios do cinema, o entendimento do espaço de um filme se limitava às imagens apreendidas pela câmera e exibidas em uma tela, associadas à noção de "vista" e ao registro do real. Os irmãos Lumière reconheciam seus filmes como "tomadas de uma vista", apresentando um objeto (dois bebês, um desfile militar, um jardineiro regando plantas), um lugar e um momento (SIETY, 2001, p. 48). Os filmes pretendiam registrar a

\footnotetext{
25 "L'image mouvante est avant tout organisation mobile d'un espace bi-dimensionnel. Sans espace, point de cinéma. En ce sens il est premier et non point subordonné". N.T.

26 ' $L$ 'espace n'est donc pas une dimension de l'image parmi d'autres (comme le son ou la lumière), mais ce sans quoi l'image cinématographique ne serai plus ele-même, ce sans quoi rien ne prendrait forme devant nos yeux". N.T.

27 “l'espace est ambigu, polyvalent, tributarie à la fois de la sensibilité visuelle - ou visionnaire - du cinéaste, de l'ideólogie ambiante, des réalités sócio-économiques d'une époque, etc. Il faut, à notre sens, aller jusqu' à reconnaître en lui une bipolarité qui condensera toutes les sommes possibles d'antagonismes contradictoires". N.T.
} 
realidade produzida diante da câmera, sem interferências, oferecendo uma ética documentarista que privilegiava as ações espontâneas dos "modelos" e suas improvisações. O espaço era, então, subordinado à ação.

Georges Méliès, precursor do cinema de ficção, iniciou no fim do século XIX, o teatro filmado com pontos de vistas únicos e uma montagem significante, sendo o primeiro a realizar filmes compostos de cenas artificialmente construídas. Ainda desconhecedor da liberdade que podia dispor, Méliès utilizava o espaço em uma construção mais complexa que incluía elementos cenográficos e mise-en-scène. Ao organizar o cenário, os objetos, os atores e sua movimentação em relação ao enquadramento da câmera, a definição de espaço se iguala à noção de "quadro" enquanto lugar central da representação. Assim, problemáticas como o limite das bordas e a composição no interior do quadro indicavam seu entendimento como lugar da ficção na construção de um mundo imaginário. Diante dos olhos dos espectadores, o espaço bidimensional da tela desaparece para dar lugar a um espaço apoiado em um sentido de abstração.

E é justamente essa abstração que conduziu algumas das abordagens teóricas instauradas no âmbito do espaço cinematográfico. O espaço no cinema se define, primeiramente, pelo quadro ("moldura" ou "janela"), espaço bidimensional limitado por suas bordas, único elemento permanente da imagem fílmica, enquanto seu conteúdo é suscetível de se mover incessantemente. Sua bidimensionalidade, dissimulada aos olhos do espectador, é percebida enquanto espaço tridimensional, apreendido em profundidade de campo e perspectivas, produzindo uma forte impressão de realidade, semelhante ao mundo que o circunda.

Alternadamente, ele é ajustado e dilatado; centrífugo e centrípeto; estritamente circunscrito e infinitamente expansivo; autônomo, ou, se preferir, abstraído do ambiente, e indissoluvelmente ligado a ele, que acabamos supondo o que existe "fora de campo" 28 (AGEL, 1978, p. 27).

O espaço percebido como tridimensional e enquadrado dentro-de-campo se mostra como um fragmento espacial capaz de sugerir um espaço fora-de-campo, construído a partir de indícios, não apenas com referências ao visível, mas para além dela. Assim, o espaço fílmico se define entre dois espaços complementares: um apreendido no

28 "Tour à tour, il est resserré et dilate; centripète et centrigue; circonscrit rigoureusement et infiniment expansif; autonome ou, si l'on veut, abstrait de l'environnement, et indissolublement lié à cet environnement que nous devinons dans ce qui existe "hors champs"”. N.T. 
espaço limitado do quadro, o outro construído a partir desse como espaço amplo e ilimitado. A continuidade entre ambos, reforçada pelo efeito da montagem, converge em um imaginário construído e percebido enquanto totalidade espacial.

Em um artigo intitulado Cinema, a arte do espaço, de 1948, Éric Rohmer diferencia o espaço cinematográfico do espaço do teatro. Enquanto no teatro, a mise-enscène fica restrita ao espaço cenográfico limitado pela presença frontal dos espectadores, no cinema a imagem transborda os limites do quadro, se abrindo sobre a existência de um espaço contínuo e dinâmico. Para Rohmer, o cinema é a arte da expressão plástica da realidade, da visualização, "que oferece aos olhos um todo que será aprazível liberar uma de suas múltiplas aparências possíveis"29 (apud CHEVALLIER, 2012, p.281). Essa noção de espaço como todo se evidencia, de modo semelhante, em André Bazin, sob a ideia de "bloco de realidade". Ao analisar os planos-sequências filmados por Orson Welles no filme Cidadão Kane, Bazin os diferencia de uma filmagem feita plano a plano. Enquanto no primeiro, diferentes ações se desenvolvem em um mesmo espaço através do uso da profundidade de campo, evidenciando as tensões dramáticas da cena, no segundo, "o acontecimento concreto é dissolvido pela metade na abstração das mudanças de plano" (BAZIN, 2005, p.91).

A concepção oferecida por Éric Rohmer e André Bazin se funda sob uma base realista, onde o termo designa o resultado da percepção da imagem cinematográfica: “o espectador percebe diretamente na própria estrutura das significações a ambivalência ontológica da realidade" (BAZIN, ibidem). Essa abordagem aproxima a percepção do espaço fílmico às experiências espaciais vivenciadas no espaço real. $\mathrm{O}$ filme não é tomado como uma série de imagens isoladas, mas de forma integrada, na dinâmica de suas interações em um sentido de totalidade espacial a ser percebido. Aqui, a missão do cinema reside na capacidade de tornar visíveis as aparências do mundo vivido e evidenciá-las, possibilitando sua percepção e apreensão.

Das análises de Maurice Merleau-Ponty (1996) sobre a arte cinematográfica, pode-se afirmar: "é pela percepção que nós podemos compreender a significação do cinema: um filme não se pensa, se percebe" ${ }^{30}$. O cinema, para o filósofo, se passa em um mundo mais exato e coeso do que o mundo real, contudo, é o dispositivo cinematográfico

\footnotetext{
29 "L'art qui nous jette aux yeux un tout dont il sera loisible de dégager l'une des multiples significations possibles". N.T.

30 "Mais enfim c'est par la perception que nous pouvons comprendre la signification du cinema: le film ne se pense pas, il se perçoit". N.T.
} 
da representação que o "filtra", segundo procedimentos estéticos, de estilo, de linguagem, oferecendo modos diferenciados de percebê-lo. Também em seus estudos sobre a percepção na expressão artística e na pintura, o filósofo apreende a arte como um filtro, analisando uma imagem do fundo de uma piscina.

Quando vejo através da espessura da água o revestimento de azulejos no fundo da piscina, não o vejo apesar da água, dos reflexos, vejo-o justamente através deles, por eles. Se não houvesse essas distorções, essas zebruras do sol, se eu visse sem essa carne a geometria dos azulejos, então é que deixaria de vê-los como são, onde estão, a saber: mais longe que todo lugar idêntico (MERLEAU-PONTY, 2004, p.37).

Assim, se por um lado, a teoria realista procurou uma estética da transparência para criar um espaço diegético, mantendo uma proximidade com a realidade vivida, por outro, teóricos e cineastas da modernidade dos anos cinquenta privilegiaram o dispositivo cinematográfico como um filtro disposto entre filme e mundo real. Dentro dessa perspectiva, o pesquisador Philippe Chevallier avalia cineastas como Robert Bresson e Jean-Luc Godard. Ambos "se esforçaram em contornar a ilusão criada pela imagem cinematográfica, para colocar novamente o espectador diante do retângulo finito que a contém [...]. Nada de cópia da vida: o espaço pró-fílmico e o espaço próprio da tela são doravante dois espaços heterogêneos"31 (2012, p.277).

Enquanto para Bresson um lugar qualquer apropriado em um filme torna-se independente de sua dinâmica da realidade, Godard se esforça em desviar a percepção natural dos espaços, apagando sua determinação espacial e deflagrando artifícios do dispositivo que convocam o espectador a perceber o espaço cinematográfico de modo diferenciado. Essa compreensão moderna do espaço cinematográfico questiona a percepção comum do espaço, atribuída pela visão realista. Aqui, a missão do cinema residiria em sua especificidade, naquilo que o diferencia, em novas experimentações e imagens para se perceber o mundo.

Também distanciado de um compromisso com a realidade vivida, o filósofo Gilles Deleuze avalia o dispositivo cinematográfico, se perguntando como "construir um espaço qualquer [...]? Como extrair um espaço qualquer de um dado estado de coisas, de um espaço determinado?" (1985, p.143). Na elaboração de sua resposta, Deleuze investiga a construção do espaço cinematográfico no expressionismo alemão, na Nouvelle Vague, na

31 "Se sont efforcés de contourner l'illusion créée par l'image cinématographique, pour remettre le spectateur devant le rectangle fini qui la contient [...]. Plus de copie de la vie: l'espace profilmique et l'espace propre de la toile sont désormais deux espaces hétérogènes". N.T. 
obra do diretor Michelangelo Antonioni. Em sua análise, para além do realismo e das inquietações do dispositivo, cineastas e movimentos artísticos elaboram o espaço de um filme no uso das cores e das sombras, na deformação de cenários, na busca de um espaço vazio, em superfícies e perspectivas, em porções fragmentadas, no domínio das formas, dos contornos, do movimento.

O espaço qualquer conserva uma única e mesma natureza: ele não tem mais coordenadas, é um puro potencial, expõe apenas Potências e Qualidades puras, independentemente do estado de coisas ou dos meios que os atualizam (que os atualizaram ou vão atualizar, ou nem um nem outro, indiferentemente) (ibidem, p.153).

É antes no imaginário, em seu sentido amplo como domínio da imaginação, do desejo, do sonho que, agora, se insere o espaço cinematográfico. Amplia-se um modo de ver e perceber o mundo real para além do que se faz visível, em nossa própria existência mental, em um espaço puramente conceitual e simbólico, abstrato. $\mathrm{O}$ espaço, com toda sua variabilidade, deixa a vista e o quadro e ganha potência como plano. Como close $u p^{32}$, o plano concentra o espaço no domínio da intimidade, no limite de sentidos obscuros, apontando para emoções profundas. Como plano geral $l^{33}$, se mostra espaço generoso, pleno de vazios, privilegiando a paisagem à figura humana. Em sua dinâmica, o espaço passa de close a plano geral, de quadro receptáculo a quadro dinâmico, da saturação à rarefação ${ }^{34}$. Do pequeno ao grande, do estático ao dinâmico, o plano se abre e se fecha, contorna, horizontaliza, enquadra e desenquadra, aplaina e dá profundidade, dá ao espaço fílmico a extensão precisa da necessidade narrativa e dramática.

O espaço fílmico não é apenas um quadro, da mesma forma que as imagens não são apenas representações em duas dimensões : ele é um espaço vivo, em nada independente de seu conteúdo, intimamente ligado às personagens que nele evoluem. Tem um valor dramático ou psicológico, uma significação simbólica; tem também um valor figurativo e plástico e um considerável caráter estético (BETTON, 1987, p.29).

A riqueza da variável espaço no âmbito do cinema, seja como lugar do imaginário, seja como condição de um dispositivo ou mesmo como aproximação ao real, se concebe

\footnotetext{
${ }^{32}$ Plano cinematográfico que enquadra apenas o rosto do personagem.

${ }^{33}$ Plano cinematográfico que privilegia o espaço ambiente, mostrando-o em sua totalidade.

${ }^{34}$ Conceitos explorados por Gilles Deleuze (1983, p.22-43) em seu estudo sobre quadro, plano e enquadramento. O quadro receptáculo é pensado a partir de sua organização interna, enquanto o dinâmico "opera como um recorte móvel" com ações e mobilidades que excedem os limites do quadro. Já a rarefação e saturação se definem pela quantidade ou ausência de componentes no interior do plano.
} 
em suas imagens sempre cambiantes, ora evidenciando personagens, ações, objetos, ora em movimentos enquadrados, fragmentando e ordenando. Assim, construído a partir de percepções visuais da vista, do quadro, do plano, o espaço fílmico se oferece em pontos de vistas diversos - totalizante, ambíguo, dramático, plástico, imaginário, simbólico, fraturado, circunscrito, dilatado -, enunciando o que André Gardies chama de "olhar espectatorial", isto é, o lugar ocupado pelo espectador diante do filme: "tudo se passa como se eu tomasse o lugar da câmera, sendo conduzido a dar lugar"35 (1993b, p.26). O lugar do espectador é um ponto de observação proposto pelo filme, o local de onde ele reconhece e apreende o espaço narrado, e também o que possibilita transmutar planos em mundo imaginário.

A história tomada em mobilidades percebidas pelo espectador define o filme como um percurso a ser atravessado, ao mesmo tempo em que propõe refletir sobre a maneira como esse mundo é erigido quando da fíç̧ão fílmica. Passo a passo, esse universo particular imerge o espectador em uma interioridade construída cena a cena ante a uma relação apoiada na interação e na dependência. Uma imersão que não implica em dominação ou ilusão, mas reconhece a parte do outro naquilo que se vê, que se sente e que se imagina.

Para tanto, encontra-se nos estudos de Michel de Certeau um modo de entender a narrativa fílmica enquanto percurso de espaço: "Onde o mapa demarca, o relato faz uma travessia". O relato é diegese: instaura uma caminhada (guia) e passa através (transgride). A narrativa é por si só percurso, começa em um ponto e termina em outro. No trajeto, espaços.

Essas aventuras narradas, que ao mesmo tempo produzem geografias de ações e derivam para os lugares comuns de uma ordem, não constituem somente um "suplemento" aos enunciados pedestres e às retóricas caminhatórias. Não se contentam em deslocá-los e transpô-los para o campo da linguagem. De fato, organizam as caminhadas. Fazem a viagem, antes ou enquanto os pés a executam (CERTEAU, 1990, p.183).

As narrativas ajustam e ordenam as mudanças de espaço, organizam os acontecimentos e estabelecem uma conexão entre eles, sendo fundamentais na compreensão de grande parte das coisas do mundo. $\mathrm{Na}$ arte cinematográfica, cada filme é um percurso narrativo singular que demarca um espaço próprio, explorando os ambientes de forma diversa, estabelecendo seus pontos de contato e orientações em um

\footnotetext{
35 “Tout se passe comme si je prenais la place de la caméra, mène a donné lieu”. N.T.
} 
contexto específico de cada história. Cada sucessão de planos atualiza porções espaciais ao mesmo tempo em que organiza um percurso narrativo, deles fazem cenas e sequências. Como planos são fixidez; como sequências, fluidez. Um plano é delimitação - os limites da tela reforçam seu espaço fragmentado - mas em seu interior, o espaço é infinito, se amplia em contato com o espectador.

Certeau nos ensina que todo relato é uma prática de espaço. "Todo dia, eles atravessam e organizam lugares; eles os selecionam e os reúnem num só conjunto; deles fazem frases e itinerários. São percursos de espaço" (ibidem, p.182). Uma narrativa fílmica, ao longo de seu andamento, atravessa ambientes distintos, fixa lugares, constitui fronteiras, coloca ordem ou desordem a objetos múltiplos. Contadas em imagens e sons, saltam de um local a outro, relacionando-os. $\mathrm{O}$ ato de narrar em um filme está permeado por espacialidades, sejam localidades, fluxos ou paisagens. No cinema, narrar é estabelecer relações diversas em práticas de espaço.

Os filmes tomam partidos espaciais, recompondo o espaço a sua maneira e oferecendo ao espectador percursos diversos para atravessa-lo. Para esta pesquisa, o indefectível espaço fílmico é resultado do espaço narrado, produzindo percepções e lugares imaginários, criando formas sensíveis para se experienciar a vida mundana. Mais do que definir um cenário para narrar uma história, o espaço coloca em jogo a própria existência da arte cinematográfica. De tal modo, podemos afirmar que o cinema é a "arte do espaço".

\subsection{O espaço diegético em filmes de ficção}

Uma das formas convencionais de se classificar um filme é a partir da diferenciação entre filme de ficção e documentário. Não pretendemos aprofundar uma análise comparativa entre essas duas categorias, apenas problematizar limites e indicações que possibilitem encontrar nas imagens ficcionais um material de trabalho com características próprias para justificar uma pretensa articulação entre espaço e personagem. Partimos então de uma apreciação proposta pelo pesquisador André Gardies (1993a), em seu livro Le récit filmique:

Existe um consenso cultural baseado na experiência, geralmente não explícito, que nos torna capazes de reconhecer se estamos diante de uma ficção ou de um documentário. Há um conjunto de traços internos devido aos quais somos capazes, ao assistir a um filme, de saber se tratase de uma ficção ou de um documentário (ainda assim, a fronteira é 
porosa e alguns filmes, arriscando possibilidades ambíguas, dificultam esta distinção) ${ }^{36}$ (ibidem, p.42).

Para além das questões formais pré-estabelecidas que, aparentemente, colaboram no reconhecimento de filmes de ficção ou documentários, é a partir de uma coerência no universo diegético das narrativas ficcionais que Gardies propõe um caminho de análise para fundamentar essa distinção. A noção de mundo diegético caracteriza o universo singular construído pelo filme povoado de objetos e regido por suas próprias leis.

O mundo diegético não é próprio ao filme de ficção ou ao filme documentário; ele está presente nos dois, mas não do mesmo modo. No primeiro ele aparece dotado de uma grande autonomia até ser percebido como auto-suficiente, o que reforça sua forte coerência interna; no outro ele procede sobretudo por momentos, por fragmentos, entrecortado ou regido pelo comentário verbal ${ }^{37}$ (ibidem, p.43).

Segundo o autor, o princípio de autonomia não se desenvolve plenamente no filme documentário devido à necessidade de estar constantemente se referindo ao mundo real. A diegese de um filme de ficção, ainda que traga alusões a esse mundo, se concebe no efeito de uma coerência entre seus elementos narrativos (tempo, espaço, personagem, ações) que acaba por contribuir na percepção deste universo como homogêneo e autossuficiente. Ao criar um mundo ficcional a partir de elementos pró-fílmicos organizados no enquadramento, na sucessão de planos, etc., o filme passa a existir por si mesmo na coesão que estabelece em seu conjunto de materialidades. Dos filmes de ficção nos interessa um mundo autônomo, capaz de criar outras realidades, alterando e reorganizando referências.

A busca de um conceito de diegese no cinema narrativo de ficção favoreceu a constituição de nosso corpus de análise e o entendimento do filme como percurso a ser edificado, evitando limitá-lo a um modo de representação dominante. Além da coerência concernente aos filmes de ficção evidenciada por André Gardies, seguimos algumas

\footnotetext{
36 "Cela signifie alors qu'existe de façon empirique um consensus culturel, généralement no explicite, sur la base duquel je suis capable, à la vision du film, de savoir s'il est de type documentaire ou fictionnel. Il y aurait donc um ensemble de traits internes grâce aux quels je serais en mesure d'établir cette distinction (néanmoins la frontière est poreuse et certains films jouant sur de possibles ambiguïtés, rendent parfois difficile cette distinction". N.T.

37 "Le monde diégétique n'est pas, à l'évidence, propre au film de fiction ou au film documentaire; il est présent dans les deux, mais pas de la même manière. Dans l'un il apparaît comme doué d'une large autonomie, jusqu'à être perçu comme auto-suffisant, ce que renforce sa forte cohérence interne; dans l'autre il procede davantage par moments, par fragments, entrecoupé ou régi qu'il est par le commentaire verbal". N.T.
} 
direções apontadas pela pesquisadora Diane Arnaud (2012, p.231-233) com o propósito de reforçar a diegese em sua dimensão processual.

A noção de diegese, inventada pela filmologia ${ }^{38}$ no início dos anos 1950 , caracteriza o mundo ficcional do filme tal qual o espectador o constrói e o compreende, o que a distingue do sentido de diegesis em Platão e Aristóteles. Contudo, a semiologia do cinema, de Christian Metz à Noël Burch, seguidamente reduziu a diegese à denotação narrativa ou ao modo de representação dominante. A tomada de uma dimensão processual a confere uma acepção mais larga (ibidem, p.231).

Em seu primeiro encaminhamento, a autora se aproxima da definição proposta por Étienne Souriau em seus estudos de filmologia. O termo diégésis, utilizado primordialmente por Aristóteles e Platão em oposição à mimésis, foi retomado no início dos anos cinquenta pelo filmólogo e aplicado ao cinema. Diegese é "tudo que pertence, na 'inteligibilidade' (como diz M. Cohen-Séat ${ }^{39}$ ), à história contada, ao mundo suposto ou proposto pela ficção do filme" (SOURIAU, 1953, p.7). Ao impor a presença do espectador na concepção de um mundo diegético, Souriau evita reduzir a diegese ao mundo representado pelo filme, buscando uma estrutura relacional para pensar o seu conceito.

A definição filmológica de diegese confronta o mundo fílmico - aquele exposto na tela - com o mundo do espectador - o mundo cotidiano da experiência humana. Diferentes elementos do filme como o tempo, o espaço, os personagens são identificados pelo espectador que é, então, convidado a conectá-los por meio de sua percepção, compreensão e imaginação. Sua participação na apreensão do filme confirma as regras de coerência interna do mundo fíccional. A diegese se dá no encontro entre filme e espectador, é um mundo a ser construído, jamais prontamente obtido.

Nesse sentido, procuramos autores que buscaram perceber a imagem cinematográfica a partir da existência de um fora-de-campo ${ }^{40}$, apreendendo o conceito de diegese próximo a mundo imaginário. No caminho, teóricos do cinema nos atentaram para um olhar externo diante da imagem na tela, um algo que se expande para além dela. Com referências ao filme Nana de Jean Renoir, Noel Burch analisou o uso do fora-de-

\footnotetext{
${ }^{38}$ O termo surgiu em 1946 no momento da criação do Instituto de Filmologia da Sorbonne e se afirmou como o estudo do universo fílmico definindo as bases de uma abordagem estética geral (AUMONT; MARIE, 2003, p.129).

${ }^{39}$ Citando COHEN-SÉAT, Gilbert. Essai sur les príncipes d'une philosophie du cinéma. Paris, PUF, 1946.

${ }^{40}$ Usamos aqui o fora-de-campo em oposição a campo definido por um plano de filme delimitado pelo espaço do quadro. Nele se inserem os elementos não vistos no quadro mas ligados a ele por "vínculo sonoro, narrativo e até mesmo visual" (AUMONT;MARIE, 2001, p.132).
} 
campo: "para compreender a natureza do espaço no cinema, pode ser útil considerar que se trata, efetivamente, de dois espaços: o que existe em cada quadro e o que existe fora do quadro ${ }^{41}$ " (1992, p.37). Burch divide ainda o espaço-fora-da-tela de outro modo, em concreto e imaginário. O primeiro se define pelos elementos fílmicos que, em algum momento, aparecem em quadro, enquanto o segundo se restringe ao não-visto, ao subentendido e jamais visto na tela. Para além de uma abordagem estrutural, sua análise alerta para um espaço construído imaginariamente pelo espectador.

Do mesmo modo, o crítico André Bazin, ao relacionar cinema e pintura na defesa dos filmes de arte, expande o espaço da tela de cinema prolongando-o para além do quadro. O quadro de uma pintura limitado por uma moldura propõe uma descontinuidade da realidade a qual pertence (ou a qual se insere): ele se fecha sobre si mesmo e se consolida como totalidade. Entendido enquanto um quadro sem moldura, a tela de cinema evidencia a imagem interna ao mesmo tempo em que reforça um possível fora de quadro, de tal modo que se consolida como fragmento. Bazin diz: "a moldura polariza o espaço para dentro, tudo o que a tela nos mostra, ao contrário, supostamente se prolonga indefinidamente no universo. A moldura é centrípeta, a tela centrífuga" (1991, p. 173). O espaço pictural transformado em obra cinematográfica adquire novos sentidos: "um universo virtual que resvala de todos os lados" (idem).

O quadro fílmico arremete o espectador de um lado para outro, de um plano para o próximo em uma trajetória de fíccionalização que se constitui não na tela, mas para além dela. Assim como Bazin, André Gardies reconhece que o quadro é o lugar de duas forças contrárias, a centrípeta e a centrífuga: a primeira "cerra meu olhar dentro dos limites que ele instaura, obriga-o a percorrer um campo perfeitamente circunscrito" 42 (1993b, p.170), enquanto a segunda faz ecoar a composição interna do quadro em outras dimensões espaciais.

Gilles Deleuze, em A imagem-movimento, parte da noção de enquadramento para analisar a dinâmica do quadro fílmico: "Chamamos enquadramento a determinação de um sistema fechado, relativamente fechado, que compreende tudo o que está presente na imagem, cenários, personagens, acessórios” (1985, p.22). As diferentes graduações do quadro, sua saturação e rarefação, o uso da profundidade de campo, os ângulos de

\footnotetext{
${ }^{41}$ Noel Burch divide o espaço fora-da-tela em seis segmentos: "os limites imediatos dos quatro primeiros segmentos são determinados pelos quatro cantos da tela"; um quinto segmento reconhecido como um "atrás da câmera" e um sexto que "compreende tudo o que se encontra atrás do cenário" (BURCH, 1992, p.38).

42 "“...] enclos mon regard au sein des limites qu' il instaure, le contraint à parcourir un champ parfaitement circonscrit".N.T.
} 
enquadramento, entre outros, refletem uma pedagogia da imagem de cineastas que a afirmam enquanto superfície de informação. Para Deleuze, o quadro não existe apenas para ser visto, mas tem uma função legível exposta em suas variações dinâmicas construídas a cada filme. Enquadrar determina necessariamente um extracampo ${ }^{43}$.

É por isso que dizíamos: há sempre um extracampo, mesmo na imagem mais fechada. E há sempre, simultaneamente, dois aspectos do extracampo: a relação atualizável com outros conjuntos, a relação virtual com o todo. Mas num caso a segunda relação, a mais misteriosa, será atingida indiretamente, no infinito, por intermédio e extensão da primeira, na sucessão das imagens; no outro caso ela será atingida mais diretamente, na própria imagem, através da limitação e neutralização da primeira (ibidem, p.30).

Assim como Noel Burch, Deleuze reconhece dois aspectos do extracampo: um relativo, que abarca elementos não vistos, mas com possibilidade de aparecerem em quadro, e o absoluto, através do qual o quadro se abre para um todo maior que não pertence à ordem do visível. O todo é como um fio que liga um enquadramento a outro, um campo e um extracampo, formando um universo ilimitado. Quanto mais tênue o fio, mais reforçado o fechamento do quadro, reduzindo sua relação com o exterior (como o quadro pictural de Bazin e sua força centrípeta). Quanto mais espesso o fio, mais o extracampo cumpre sua função de "acrescentar espaço ao espaço", atestando "uma presença mais inquietante, da qual nem se pode mais dizer que existe, mas antes que 'insiste' ou 'subsiste', um alhures mais radical, fora do espaço e do tempo homogêneos" (ibidem, p.29).

O espaço do quadro fílmico instiga a pensar na imagem figurada em uma tela, seja em sua organização interna, seja por meio do fora-de-campo o qual remete. A imagem vista se estende para além do quadro: no plano subsequente em um novo ponto de vista, na dinâmica interna da mise-en-scène, na sucessão de planos que organizam a narrativa e na imaginação do espectador, dando um sentido de totalidade chamado "filme". O universo enquadrado pela câmera não se abre apenas para dimensões espaciais, mas pontua a existência de outras imagens que se formam alhures.

Pensar um fora-de-campo é atentar para a construção fílmica no âmbito da imaginação. O filósofo Gaston Bachelard, em sua análise fenomenológica da imagem poética, impulsiona a perceber o espaço como um poema, com toda nossa imaginação.

\footnotetext{
${ }^{43} \mathrm{O}$ termo é utilizado como substituto de fora de campo, porém nega uma referência espacial. O extracampo ultrapassa a dimensão visual e referencia o "trans-espacial" em um sistema aberto e infinito.
} 
“Trata-se, com efeito, de determinar, pela repercussão de uma única imagem poética, um verdadeiro despertar da criação poética na alma do leitor" (2003, p.7). Para Bachelard, a obra de arte não se encerra em sua leitura, ela nos invade e ecoa em nós. Ao se defrontar com o poema, o leitor é também criador; dele, cria imagens mentais. A palavra criar vem do latim creare, que significa produzir, erguer, e se relaciona a crescer. O cinema ressoa sons e imagens que repercutem em nossa imaginação criadora, seu universo diegético ultrapassa o espaço da tela e faz crescer nosso imaginário. As imagens na tela não se perfilam diante de nossos olhos, nós ${ }^{44}$ as atravessamos. Ao penetrarmos nas imagens de um filme, invadimos seus espaços, nos embrenhamos em cantos e passagens, tomamos posse e erguemos um mundo todo. A leitura de um filme se assemelha à leitura de um poema, nos toma por inteiro.

As ressonâncias dispersam-se nos diferentes planos da nossa vida no mundo; a repercussão convida-nos a um aprofundamento da nossa própria existência. Na ressonância ouvimos o poema; na repercussão o falamos, ele é nosso. A repercussão opera uma inversão do ser. Parece que o ser do poeta é o nosso ser (idem).

Bachelard valoriza a dualidade sujeito e objeto, ele prolonga o poema e o expande à imagem poética: "pede-se ao leitor de poemas que não encare a imagem como um objeto, muito menos como um substituto do objeto, mas que capte sua realidade específica" (ibidem, p.4). Assim como ele, Burch, Bazin e Deleuze nos ensinam a apreender a realidade específica do cinema, buscando um espaço invisível na constituição da visibilidade de um filme. Quanto mais o cinema se liberta das amarras do espaço visível na tela, quanto mais ele se apropria de outros espaços fora-de-campo, mais ele se aproxima de sua natureza espacial. A imagem cinematográfica não está na tela apenas para ser vista, mas para ser apreendida no fora-de-campo, na ausência, nos intervalos, nos entre-planos e nas entre-sequências.

Diante dessas considerações, afirma-se que o espaço diegético figura no quadro fílmico e a partir dele: de um lado a materialidade fílmica se revela espacialmente (da decupagem de direção à sua organização plástica, do movimento dentro do quadro à dinâmica da montagem), do outro o espectador prolonga suas proposições, limitações e ausências em imaginações que edificam o mundo diegético do filme. A concepção de

\footnotetext{
${ }^{44}$ Quando uso o pronome nós, posiciono o lugar que ocupo nesta tese, ora como pesquisadora, ora me incluindo como espectadora diante dos filmes que analiso. Ainda que o termo proponha uma igualdade, reconhece-se aqui a individualidade e a subjetividade na apreensão das narrativas fílmicas.
} 
diegese apresentada por Marc Vernet, em seus estudos sobre a estética do cinema, ajuda a complementar a reflexão sobre o espaço diegético. Vernet define a diegese como um mundo a ser construído em um processo de elaboração progressiva onde diferentes elementos se organizam para formar um todo. Cada espectador percorre e constrói, de modo singular, um pseudo mundo pleno de mobilidades.

Finalmente, da nossa parte, nos sentimos tentados a entender também por diegese a história tomada em sua dinâmica da leitura do relato, ou seja, tal como se elabora no espírito do espectador na evolução do desenvolvimento fílmico. Não se trata, neste caso, da história tal como pode ser reconstituída depois da leitura do relato (a visão do filme) finalizado, mas a história tal qual a formo, a construo a partir dos elementos que o filme me proporciona "gota a gota" e tal como meus fantasmas do momento ou os elementos retidos dos filmes vistos precedentemente me permitem imaginar. A diegese seria aqui a história tomada em sua plástica da leitura, com suas falsas pistas, suas dilatações temporais ou, ao contrário, seus assentamentos imaginários, com suas cisões e suas integrações passageiras, antes que uma história se defina e que eu possa contá-la do princípio ao fim de forma lógica (VERNET, 2012, p.115).

\subsection{A dimensão sonora na percepção do espaço}

Ao investigar espaços no cinema em um modo transdisciplinar, nos deparamos com os estudos fenomenológicos da arquitetura para valorizar a dimensão sonora na apreensão do espaço ficcional. Em seu livro Os olhos da pele, o arquiteto Juhani Pallasmaa investigou a combinação dos sentidos na apreensão da arquitetura e constatou que grande parte das construções arquitetônicas é considerada primordialmente sob um sentido, o da visão. Segundo o autor, desconsiderar os demais sentidos, além de reduzir o sentido da própria arquitetura, provoca alienação e distanciamento, dificultando a sensação de pertencimento e integração espacial. Vivenciar um espaço é não se limitar às suas medidas e superfícies, mas apreendê-lo por meio dos sentidos, afirmando nossa existência no mundo. Em suas palavras, Pallasmaa propõe um caminho multissensorial para perceber e vivenciar o espaço arquitetônico.

Eu confronto a cidade com meu corpo; minhas pernas medem o comprimento da arcada e a largura da praça; meus olhos fixos inconscientemente projetam meu corpo na fachada da catedral, onde ele perambula sobre molduras e curvas, sentindo o tamanho de recuos e projeções; meu peso encontra a massa da porta da catedral e minha mão agarra a maçaneta enquanto mergulho na escuridão do interior. Eu me 
experimento na cidade; a cidade existe por meio de minha experiência corporal. A cidade e meu corpo se complementam e se definem. Eu moro na cidade, e a cidade mora em mim (PALLASMAA, 2011, p. 37$38)$.

É no encontro do andante com os espaços percorridos que a cidade passa a existir. A arquitetura se edifica na imersão do homem em seu ambiente; e na interação entre corpo e espaço, todos os sentidos são solicitados. Ao se movimentar, o corpo encontra obstáculos (prédios, portas, grades, pilares, etc.) e guias (ruas, travessas, caminhos, corredores, etc.) que direcionam suas andanças: com as mãos, abre e fecha as aberturas, e também pede ou impede passagens; na trama sonora orienta suas verticalidades e horizontalidades; ao se deslocar, alcança odores e aromas característicos de cada recinto e se insere espacialmente.

Pallasmaa se serve dos estudos do filósofo Maurice Merleau-Ponty para justificar a centralidade do corpo humano nas experiências mundanas; juntos, corpo e mundo formam um sistema de sentidos inter-relacionados e se redefinem continuamente. "Toda percepção exterior é imediatamente sinônima de uma certa percepção de meu corpo, assim como toda percepção de meu corpo se explicita na linguagem da percepção exterior”, nos diz Merleau-Ponty (1999, p.277). É a partir de nossa percepção corporal que percebemos e apreendemos o mundo e os objetos que nos rodeiam. O corpo media a nossa interação com o mundo por meio dos diferentes sentidos, assegurando a individualidade humana. Da visão, traçamos um horizonte e nele apreendemos formas e perspectivas; do olfato, sentimos aproximações e afastamentos; dos ruídos percebidos nos situamos; com as mãos e os pés, medimos distâncias e traçamos localidades. O espaço vivenciado se edifica a partir de nossas percepções, e a cada percepção, nosso corpo se posiciona enquanto instrumento de medição. Ao nos movimentarmos, atualizamos, a cada instante, o mundo percebido em proporções e grandezas espaciais.

Da percepção espacial alcançada pelo corpo em suas movimentações, passamos aos espaços experimentados na apreensão da arte cinematográfica. Em um primeiro momento, consideramos o espaço da sala de exibição. Nesse recinto, ocupamos o lugar de espectador: nosso corpo inerte observa personagens e lugares que perfilam em uma tela. Somos tomados em uma espécie de congregação entre sentidos e materialidades fílmicas. Nossos olhos e ouvidos concentram nossa atenção em sons e imagens bidimensionais que nos mobilizam de modo semelhante ao mundo tridimensional vivido. Juhani Pallasmaa nos diz que a "visão periférica nos integra com o espaço, enquanto a visão focada nos arranca para fora do espaço, nos tornando meros espectadores" (ibidem, 
p. 13). Seu argumento é que o espaço experimentado pelo corpo, estimulado pela visão periférica, aguça nossa percepção sensorial e nos insere de modo centralizado no espaço.

No cinema, ainda que o ato de assistir a um filme não estimule uma visão periférica, estamos completamente envolvidos pelo “indefectível espaço fílmico". Nesse sentido, entendemos que a materialidade sonora de um filme cumpre um papel primordial na construção do espaço diegético e, consequentemente, em nossa inserção como espectadores na diegese fílmica. Podem os elementos sonoros de um filme (som ambiente, ruídos, trilha musical, etc.) suprirem a ausência de uma possível visão periférica da qual nos fala Pallasmaa?

Os filmes de ficção sugerem espaços sonoros construídos com base em nossas experiências sensoriais. Cada cena ou sequência organiza suas materialidades, ora recriando ambientes sonoros, ora propondo novas sonoridades sujeitadas a um contexto narrativo. O som impede que uma visão focada na tela nos arranque para fora do espaço e nos reduza à posição de meros espectadores. A percepção de um espaço lateral proporcionada pelo sentido da audição em uma sala de cinema durante a exibição de um filme ${ }^{45}$ colabora na sensação de pertencimento do espectador no mundo diegético proposto, incitando sua inserção de modo centralizado no âmbito do espaço fílmico.

Na constituição de uma diegese, o espaço criado pelo som é tão importante quanto ao proposto pela imagem. O som expande a imagem vista na tela de cinema ativando um espaço ausente por meios como o som fora-de-campo ou o som off ${ }^{46}$. Com o filósofo Gilles Deleuze, "não é o sonoro que inventa o fora-de-campo, mas é ele que o povoa e que preenche o não-visto visual com uma presença específica” (DELEUZE apud AUMONT; MARIE, 2003, p.133). A imagem se apresenta povoada de objetos, ambientes e personagens, do mesmo modo, o som está prenhe. O espaço construído por elementos sonoros (vozes, ruídos, silêncios, som ambiente e músicas) se consolida enquanto discurso paralelo que influencia e assegura o espaço proposto na imagem fílmica. No confronto entre imagem e som, campo e fora-de-campo, se cria o espaço diegético de um

\footnotetext{
${ }^{45}$ Aqui apontamos para a presença de um sistema sonoro de multicanais, como o Dolby Stereo, que distribui os sons do filme em diversas áreas da sala de exibição, provocando a sensação de que há variadas fontes sonoras. Neste sistema, a configuração das caixas de som no recinto onde se encontra a tela explora a lateralidade na orientação espacial do espectador em relação à imagem vista. Assim, os sons preenchem o ambiente de forma igualitária proporcionando um espaço acústico tridimensional semelhante ao "espaço vivido".

46 Segundo Michel Chion (1985), no som fora-de-campo, a fonte não está visível na imagem mas situada no espaço-tempo diegético, enquanto no som off, o som emana de uma fonte não diegética como por exemplo a voz de um narrador ou uma música de fundo.
} 
filme. Juntos articulam uma experiência espacial com referências ao filme exibido em um tecido sonoro e imagético formado de um emaranhado de materialidades e espacialidades.

O estudo da relação entre imagem e som pode ser aprofundado por meio das pesquisas do compositor pesquisador Michel Chion que encontrou no termo "audiovisão" um caminho para refletir sobre o elo que se estabelece entre audição e visão durante a exibição de um filme. Sua pesquisa questiona o som enquanto elemento subordinado à imagem fílmica, limitado a duplicar significados manifestos pela imagem. $\mathrm{O}$ valor informativo e sensorial do audiovisual parece emanar apenas da imagem, entretanto a percepção da imagem na tela de cinema depende fortemente do som. O som intervém na percepção que o espectador tem da imagem, incitando um modo perceptivo chamado audiovisão. Ainda que a visão e a audição suscitem percepções específicas, em um filme "o som faz ver a imagem de modo diferente ao que esta imagem mostra sem ele, a imagem, de sua parte, faz ouvir o som de modo distinto a que este ressoaria na obscuridade" (2011, p.31). Ambos se complementam e é na dinâmica dessa complementariedade que o cinema edifica espaços diegéticos.

Em um filme, as combinações entre imagens e sons articulam dimensões espaciais variadas: há momentos em que o som repete o sentido proposto pela imagem vista; em outros parece desmentir o que ela exibe, criando espaços simbólicos e expressivos; em certas ocasiões, o som estende a imagem exibida e edifica lugares para além do enquadrado; em outras explora a lateralidade do espectador com ruídos que circulam de um lado para outro complementando o que a imagem não nos pode mostrar. A materialidade sonora repercute na imagem e para além dela, aguçando nossa percepção espacial e gerando espacialidades diversas.

O cinema de ficção nos abastece de exemplos: no filme brasileiro $O$ som ao redor (2012) de Kleber Mendonça Filho, acompanhamos um casal que visita um cinema abandonado; na imagem vemos apenas mato e ruínas, mas uma trilha sonora insinua um filme de terror e nos leva a acessar um espaço não visto. Em uma cena do filme Medianeras (2011) do argentino Gustavo Taretto, o som de um piano, supostamente tocado em um apartamento vizinho, preenche de tal forma a quitinete de uma jovem que, além de construir um espaço ausente da tela (uma provável vizinhança), amplifica nossa percepção espacial, inserindo uma possível relação de contiguidade entre o visto e o nãovisto. Ainda no filme brasileiro Transeunte (2010) de Eryk Rocha, fones de ouvido e a escuta de um rádio afirmam a solidão de um aposentado que insiste em trafegar entre as aglomerações das ruas da cidade; enquanto o som permanece no âmbito do indivíduo 
demarcando um ponto de vista subjetivo, a imagem afirma a transitoriedade de uma cidade efêmera.

Nos filmes de ficção, a escuta de sons e silêncios consiste em uma percepção apreendida enquanto entendimento espacial. Somos seres que escutam e experimentar um espaço é vivenciá-lo com todas as suas sonoridades. O tratamento acústico (excessos de barulho, reverberação, sons amplificados, ecos, estridências de volumes, vozes baixas, silêncios, etc.) trabalhado a cada cena arquiteta ambientes sonoros ${ }^{47}$ semelhantes aos vivenciados no mundo real. "Um grito, um ruído. Sua ressonância nos faz descobrir uma casa, uma floresta, um campo, uma montanha. Sua repercussão nos indica as distâncias"48, diz Robert Bresson (1988, p. 100). Cada lugar tem suas peculiaridades sonoras, e repeti-las em um filme recria sua atmosfera, levando-nos a perceber e reconhecer os lugares propostos. Entretanto, o acréscimo de um simples ruído é passível de alterar a atmosfera de um lugar já conhecido, descaracterizando-o a favor da narrativa proposta. Uma banda sonora constrói espaços diferenciados, devassando os limites de imagens enquadradas e fragmentadas.

Concluímos que a percepção e a construção de um espaço diegético necessitam dos elementos sonoros para adquirir consistência e materialidade. Assim, nos aproximamos do conceito de "paisagem sonora" proposto pelo compositor canadense Raymond Murray Schafer:

O ambiente sonoro. Tecnicamente, qualquer porção do ambiente sonoro
vista como um campo de estudos. O termo pode referir-se a ambientes
reais ou a construções abstratas, como composições musicais e
montagens de fitas, em particular quando consideradas como um
ambiente (2001, p. 366).

Ainda que em suas pesquisas não estejam incluídas as paisagens sonoras do cinema, Schafer observa paisagens sonoras naturais e ambientes acústicos construídos, considerando-os sob a perspectiva do ouvinte. "O que o analista da paisagem sonora precisa fazer, em primeiro lugar, é descobrir os seus aspectos significativos, aqueles sons que são importantes por causa de sua individualidade, quantidade ou preponderância” (ibidem, p. 25). Em sua categorização de sons fundamentais, sinais e marcas sonoras, o

\footnotetext{
${ }^{47}$ Aqui falamos do som direto captado durante a filmagem das cenas adicionado ao som ambiente e aos ruídos no processo de finalização de som de um filme, isto é, da banda sonora construída para cada cena ou sequência.

48 "Un cris, un bruit. Leur résonance nous fait deviner une Maison, une fôret, une plaine, une montagne. Leur rebond nous indique les distance". N.T.
} 
autor identifica os sons básicos e os sons significativos que constroem paisagens sonoras diferenciadas: paisagens domésticas, urbanas, marítimas, fábricas, parques, jardins, etc. Cada lugar oferece sua própria paisagem sonora preenchida de sons, silêncios, vozes, ruídos característicos, e deles se serve o cinema.

Assistindo a um filme, os sons que escutamos provocam nossos estímulos sensoriais e consolidam situações espaciais próprias de cada narrativa, muitas vezes não sugeridas ou sugeridas sutilmente pela imagem. Ao discorrerem sobre o espaço na narrativa cinematográfica, Gaudreault e Jost (2009, p.108-109) enumeram instâncias onde possíveis eventos fílmicos estariam privados de seu quadro espacial: cenas escurecidas, tela preta, ausência de cenários, enquadramentos restritos que impedem o espectador de perceber o ambiente de modo mais preciso. No entanto, na apreensão de uma situação espacial em um filme de ficção é preciso levar em consideração não apenas a imagem na tela, mas as paisagens sonoras construídas pela materialidade fílmica.

Para além das imagens, os elementos sonoros fundam ambientes e localidades. De ruídos urbanos exacerbados apreendemos uma metrópole, embora nas imagens estejam enquadradas apenas uma ou duas habitações; dos barulhos de carros que trafegam sem parar imaginamos uma avenida, mesmo que na tela haja apenas escuridão; do badalar de sinos conseguimos perceber o ambiente de uma igreja, ainda que as imagens mostrem tão somente pequenos fragmentos de sua edificação. Se as imagens nos apontam algumas referências espaciais, o som incita a nossa inserção em lugares específicos que se afirmam em suas particularidades. Dos componentes sonoros, o som ambiente ${ }^{49}$ nos conecta a lugares determinados ao mesmo tempo em que amplia nossa experiência perceptiva do espaço diegético.

Para Michel Chion, os sons ambientes são sons-territórios "porque servem para marcar um lugar, um espaço particular, com sua presença contínua e estendida por todas as partes" (2011, p. 86). O som ambiente aproxima uma imagem a outra, restitui unidade aos ínfimos fragmentos fílmicos, institui um espaço diegético percebido em sua inteireza. Em cada filme, percebemos porções espaciais desvendadas em imagens "plano a plano", mas em seus ruídos e sonoridades alcançamos lugares em toda sua completude. Entre um plano e outro, há um corte espacial que preenchido pelo som ambiente nos leva a conceber uma sequência ou uma cena em um entrelaçamento contínuo de imagens e sons. O som ambiente comporta transmutar ruptura em junção; oferece horizontalidade. Daí passa-se

\footnotetext{
${ }^{49}$ Som ambiente é o som característico de cada lugar preenchido de ruídos e silêncios que o diferenciam e o identificam.
} 
à profundidade do campo sonoro. Enquanto a imagem geralmente é conduzida por pontos de vistas sucessivos, a banda sonora se compõe de estímulos que, sobrepostos, são percebidos simultaneamente em um fluxo ininterrupto que se aproxima ao experimentado no espaço tridimensional, como analisado por Pallasmaa:

\begin{abstract}
A audição estrutura e articula a experiência e o entendimento do espaço. Normalmente não estamos cientes da importância da audição na experiência espacial, embora o som muitas vezes forneça o continuum temporal no qual as impressões visuais estão inseridas. Quando removemos a trilha sonora de um filme, por exemplo, as cenas perdem sua plasticidade e o senso de continuidade e vida (ibidem, p. 47).
\end{abstract}

Centralidade, horizontalidade, profundidade são dimensões exploradas pela materialidade sonora de um filme e que pressupõem uma concepção norteadora do espaço delimitado na tela de cinema. Mas que outras dimensões espaciais o som nos permite apreender que escapa à imagem? Para refletir sobre a questão, nos servimos dos dizeres do compositor Schafer: "os olhos apontam para fora; os ouvidos, para dentro" (ibidem, p. 29), ou da fala do arquiteto Pallasmaa: "o espaço analisado pelo ouvido se torna uma cavidade esculpida diretamente no interior da mente" (ibidem, p.47). A imagem cinematográfica oferece dimensões espaciais exteriorizadas na tela, enquanto o som as interioriza em nós.

Talvez a palavra embrenhar-se contemple um modo de estar no espaço fílmico afigurado em um contínuo de possibilidades sonoras, sejam vozes, ruídos, silêncios, sons ambientes ou músicas. Embrenhar-se é um movimento para o interior em direção às "profundezas". No cinema, os sons e sonoridades nos possibilitam passar da tela ao filme. De imergir da superfície para as profundezas, já nos inspirou Gaston Bachelard em suas imagens poéticas. Para o filósofo, uma única imagem repercute em nós: “É depois da repercussão que podemos experimentar ressonâncias, repercussões sentimentais, recordações do nosso passado. Mas a imagem atingiu as profundezas antes de emocionar a superfície” (2003, p.7). Aqui, dizemos que um único som repercute várias imagens, provoca ressonâncias, faz recordar lugares e ambientes. É em nossa imaginação que nos deparamos com as paisagens sonoras dos filmes de ficção, e delas nos servimos para expandir os limites da tela.

Para Murray Schafer, a "audição é um modo de tocar à distância” (ibidem, p.28). Sua afirmação se aproxima do caminho multissensorial proposto por Juhani Pallasmaa para perceber a arquitetura. A percepção de um espaço não se dá apenas pela visão, mas pela existência de um ambiente acústico assimilado e reconhecido pelo espectador. A 
imagem de um objeto na tela de cinema torna-se manifesta em nossa imaginação pelo som que emana, convocando nossa memória. Pela percepção sonora, espaços e lugares se fazem tangíveis. No cinema, o som deixa tocar à distância rios, pássaros, árvores, chuvas, portas, janelas, objetos que são as porções sonoras de universos diegéticos erguidos em um emaranhado de sonoridades. São as ondas sonoras que propagam ruas, monumentos, cidades em nossa imaginação.

\section{MODOS DE HABITAR EM FILMES DE FICÇÃO}

\subsection{Modos de habitar como topografia fílmica}

Certos filmes criam sentidos e visibilidades para se perceber modos de habitar em um entendimento de vida cotidiana associada às mobilidades da contemporaneidade urbana. Isso nos leva à problemática do espaço cinematográfico na composição e constituição de narrativas ficcionais, se apresentando como um trabalho mais complexo quando relacionado ao estudo do espaço no campo das obras literárias. Além da complexidade de seu material de expressão (imagens e sons $)^{50}$, o espaço cinematográfico é construído em uma infinidade de relações: em combinações com o espaço real que se oferece como referência e matéria-prima para a captação das imagens; na afirmação de um ponto de vista sobre esse real, posicionando o olhar do espectador; na composição e construção dos cenários, no uso de cores, luz, objetos cenográficos que permeiam a produção e a criação audiovisual; no uso da linguagem cinematográfica apreendida em planos e contra-planos, enquadramentos, profundidade de campo, movimentos de câmera; na infinita conexão desses planos em temporalidades, impondo consistências ou fragmentações; etc.

Por essa razão, se impôs a necessidade de encontrar um caminho para pensar o espaço, a partir dos filmes selecionados, em uma percepção relacional concebida através de diferentes elementos temáticos, narrativos, das visualidades, espacialidades e formalidades que se desprendem na constituição desses encontros e confrontações. Para tanto, resgata-se a hipótese de que para narrar modos de habitar em filmes ficcionais é

50 Em conformidade com os estudos de Christian Metz (1980), são cinco as pistas de expressão cinematográficas : imagem, diálogos, ruídos, música, materiais escritos). 
preciso uma organização espacial que dê conta da multiplicidade de materialidades fílmicas.

Com isto, voltamo-nos para o conceito de topografia fílmica ${ }^{51}$ apresentado por André Gardies. O pesquisador francês, ainda que apoiado em teorias semióticas para desenvolver algumas de suas análises, se debruçou especificamente sobre o tema do espaço cinematográfico. Sua pesquisa esmiúça o espaço em diferentes dimensões da arte cinematográfica, desde o espaço do espectador com seu conceito de "olhar espectatorial", até sua relevância na constituição de uma narrativa fílmica. Nesta tese, nos servimos de seu trabalho no que diz respeito à constituição de uma topografia fílmica como base para o entendimento de uma categoria de espaço, reconhecida aqui como modos de habitar, inserida em dinâmicas urbanas da contemporaneidade, porém em experiências narrativas de mundos íntimos e práticas cotidianas. A ideia é que, em filmes ficcionais, os modos de habitar só existem enquanto topografia, na interseção entre espaço, lugares e personagens, e entre filme e espectador.

Gardies se apropria do termo topografia dos estudos geográficos, que em sua origem grega se compõe de topos que significa "lugar" e grapho que indica "descrição", para acomodá-lo à narrativa cinematográfica: "Para dar conta da funcionalidade narrativa do espaço, a topografia deverá cuidar, sobretudo, das relações instauradas pela narrativa entre os diversos componentes espaciais" (1993b, p.108). A topografia fílmica se apresenta como uma estratégia narrativa para criar espaços em um sentido de totalidade, a partir de uma abordagem relacional. $\mathrm{O}$ autor indica caminhos para os princípios de sua elaboração fundados na relação espaço-lugares e lugares-personagens.

À medida que a narrativa avança, sobre a base das proposições fílmicas, o espectador elabora uma espécie de modelo abstrato de organização de conjunto, graças ao qual, simultaneamente, se assegura um efeito de coerência e se apreende o jogo relacional dos diversos componentes espaciais. Assim, uma verdadeira topografia da narrativa se constrói ${ }^{52}$ (ibidem, p.108).

\footnotetext{
51 Conceitos semelhantes como "geografia das cidades" (OLIVEIRA JR., 1999), "atlas da emoção" (BRUNO, 2002), "deslocografia" (GOSCIOLA; MAGNO, 2011) também se apresentam com o propósito de elucidar as preocupações do cinema com as novas geografias do mundo contemporâneo, investigando as dinâmicas espaciais a partir do olhar do cinema.

52 “A mesure qu'avance le récit, sur la base des propositions filmiques, le spectateur elabore une sorte de modele abstrat de l'organisation d'ensemble grâce auquel à la fois s'assure un effet de cohérence et s'appréhende le jeu relationnel des diverses composantes spatiales. Une véritable topographie du récit se construit ainsi".
} 
Primeiramente, instituir uma topografia fílmica é renunciar ao objeto real e a suas dimensões físicas, e apropriá-lo a serviço de uma narrativa, reconstituindo-o aos poucos e de modo fragmentado. O lugar tomado como referência - uma rua, uma casa, um edifício - e sua constituição física (como seu tamanho, seu volume, sua superfície) assumem aqui um papel secundário. As imagens e sons que tecem o filme propiciam a "desfragmentação" desses lugares e de suas características físicas, simbólicas, expressivas previamente constitutivas, que passam a se constituir de um outro modo: apenas para a ficção. Relacionar elementos espaciais em um filme faz emergir lugares narrativos e uma topografia que possibilita avançar a história em novas percepções espaciais.

\begin{abstract}
Notaremos que os diversos traços, se eles dizem respeito aos lugares, de uma parte não são todos "figurados" (de certo modo, somente aqueles que mencionam as características físicas), de outra parte resultam de uma atividade interpretativa do espectador colocando em relação personagens, ações e lugares [...]. O espaço assim "construído" não se reduz à simples adição das diversas características próprias de cada lugar: ele é tanto composto de elementos quanto de relações. A "percepção" deste espaço revela um ato cognitivo e engaja o funcionamento narrativo. É ele que visa a descrever a "topografia", cujos princípios metodológicos devem ser estabelecidos (ibidem, p.110 $)^{53}$.
\end{abstract}

Das orientações dadas por André Gardies, pensamos em instituir modos de habitar em filmes ficcionais a partir de uma noção de topografia que se ergue na fronteira entre descrição e narração, entre intenção e percepção. Para tanto, posiciona-se uma contraposição entre descrever e narrar, aproximando-os enquanto movimento de mãodupla na concepção de uma topografia própria do cinema. O estudo do pesquisador Jessie Martin sobre a descrição no âmbito da análise fílmica nos favoreceu em um primeiro momento. O autor se serve do conceito de "ekphrasis" para iniciar sua argumentação sobre a descrição analítica: "não se trata mais tanto de criar, de produzir uma obra (ou um lugar, ou um acontecimento) pela escrita (com palavras habilmente organizadas), mas de veicular pela escrita o poder da obra"54 (2011, p.23). Criada pelos gregos, a palavra ekphrasis designava uma descrição precisa e detalhada, inicialmente de pessoas, objetos

\footnotetext{
53 'On notera que ces divers traits, s'ils se rapportent aux liwux, d'une part ne sont pas tous 'figurés' (seuls ceux qui touchent aux caractéristiques physiques le sont) d'autre part résultent d'une activité interpretative du spectateur mettant aussi bien en relation des personnages que des actions ou des lieux [...]. L'espace ainsi 'construit' ne saurait donc se réduire à la simples addition des diversses caractéristiques propres à chaque liwu: il est tout autant compose d'éléments que de relations". N.T. 54 “ “...] il ne s'agira plus tant de créer, de produire une oeuvre (ou un lieu, ou un événement) par l' écriture (des mots savamment agencés), mais de véhiculer par l'écriture le pouvoir de l'oeuvre". N.T.
} 
ou lugares, e mais tarde, usada para descrever obras de arte. Esse discurso descritivo era muitas vezes incorporado a uma narrativa desenvolvida pelo "descritor", o que permitia "integrar o descritivo dentro do narrativo e o narrativo ao descritivo" (ibidem). Martin reconhece que a descrição analítica se faz como uma ekphrasis: entre a descrição da história e o modo como ela é narrada, de tal modo que ora é movimento, ora estagnação.

Ao aproximar a noção de ekphrasis à definição de topografia de André Gardies, amplia-se seu entendimento. Nesta tese, para concretizar a topografia de um filme, pressupõe-se um caminho de mão-dupla: considerando os modos de habitar como descrições de lugares, e ao mesmo tempo, assumindo-os enquanto percursos de espaço. Segundo Gardies, a percepção de um espaço se dá, primeiramente, na variabilidade de suas dimensões como linhas, superfície, volume. Fundar uma topografia fílmica é perceber objetos e lugares descritos em suas dimensões e aparências, e deles compor uma narrativa.

A topografia fílmica, como descrição e narrativa, "leva ao espectador diversas informações diegéticas sobre os lugares, os personagens, a ação em curso e seus problemas; enquanto trabalha também a outro nível menos visível: o da organização espacial"55 (ibidem, p.109). De um ponto a outro da narrativa, imagens e sons descrevem em detalhes personagens, lugares, objetos em uma dinâmica espacial que se dá entre o filme e o espectador. Nesse percurso, há uma intenção própria de cada filme que concebe, por meio da topografia, espacialidades diversas. Nele, se encontra o espectador que dá sentido a essas espacialidades, fazendo conexões, pressuposições e juízos.

Voltamos a recusar a ideia de um espectador passivo que apenas observa, mas ao contrário, é parte colaborativa na constituição de uma topografia fílmica. O espaço é tomado enquanto conjunto no encontro entre grandezas, perspectivas e superfícies. De uma porta e uma janela, percebe-se uma casa; de um hall e uma escada, apreende-se uma edificação; de uma esquina e uma avenida, compreende-se uma cidade; aqui as grandezas e proporções são alcançadas em uma medição cinematográfica.

A continuidade entre planos encaminhada por meio da montagem de um filme impõe uma variedade de conexões possíveis que relacionam dimensões espaciais de formas diversas, obtendo modos de narrar. Junções, contradições, comparações espaciais propiciam percorrer a narrativa enquanto percurso de espaço. Ao mesmo tempo, os

\footnotetext{
55 “ [...] apporte au spectateur diverses informations diégétiques, sur les lieux, les personnages, l'action en cours et ses enjeux; cependant il travaille aussi à un aurte niveau, moins immédiatement visibles: celui de l'organisation spatiale". N.T.
} 
ínfimos fragmentos espaciais expõem materialidades e delas fazem narrativas. Da cor escura, certa sofreguidão; das linhas paralelas, ordem e ritmo; da textura, um pouco de densidade e substância. A imagem se abastece de plasticidades e dela inventa espacialidades.

Em seus estudos comparativos entre cinema e pintura, o pesquisador Jacques Aumont investiga o modo como as imagens de um quadro trabalham para contar histórias. Para ele,

[...] a narrativa informa o espaço, marca-o; e, portanto, que todo espaço é, ao menos virtualmente, marcado pela narrativa. Onde ver tais marcas? Um pouco em toda parte: no uso da profundidade de campo fotográfica, no jogo dos enquadramentos, portanto dos: ângulos e das distâncias, e é claro, no próprio corpo, nos gestos, nos olhares dos figurantes (2004, p.141).

A noção de espaço percebido e apreendido em imagens e sons se manifesta com base em intenções provocadas pela narrativa. A narrativa traz informações espaciais ao mesmo tempo em que provoca junto ao espectador um certo sentido de espaço. Cada objeto, cada lugar possui uma individualidade própria que abastece a imagem de significados e emoções. Para Aumont, o filme não é recebido como "um simples desfilar, mas dá lugar a um processo infinito de soma, de comparação, de classificação, em suma, de memória, que, por definição, fixa o tempo - em uma espécie de 'espaço', se se fizer questão" (ibidem, p. 140).

Narrar um lugar é mostra-lo sob pontos de vista diferenciados, é oculta-lo enquanto mimesis e permiti-lo como meio de transformação; é dar-lhe movimento, ultrapassar sua forma, metamorfoseá-lo, propor um olhar individualizado diante do objeto. É "metamorfose ambulante, do que ter aquela velha opinião formada sobre tudo". Daí, narrar modos de habitar é eregir topografias que desconstroem o lugar real e criam lugares metamorfoseados. "Topografia" nos parece um conceito duro, inserido em um sistema de coordenadas cartesiano, porém, associado à noção de ekphrasis se desprende e fica prenhe de mobilidades; da descrição ergue a narrativa, do infímo alcança o todo; é movimento, mas também estagnação, se faz no fluxo da montagem e é puro fragmento.

De uma casa, metamorfoseando se fazem vários modos de habitar. As ideias preconcebidas das casas que conhecemos se renovam em materialidades diversas evocadas nas telas de cinema. Cada filme é um filme, cada casa é um modo de habitar que se ergue e se constitui entre personagens, lugares, objetos... e espectador. Descrever o modo como personagens habitam em narrativas ficcionais é conceber universos que se 
consolidam enquanto percursos singulares. A cada plano, a cada modo de habitar se ergue, aos poucos, uma espacialidade engajada: soleira, pé, fachada; quarto, janela; soleira, bancada, mão, corredor, telhado, chuva, janela; soleira, rua, porta afora. Plano a plano, a imagem fragmentada repõe, uma a uma, porções do habitar.

Contudo, o habitar não se faz no somatório de planos, mas no encontro, na interseção. Um somatório nos remete a algo preciso, enquanto a interseção depende do encontro para acontecer. A interseção é sempre inusitada, imprevisível. Enquanto a somatória segue uma sequência, a interseção é um espaço aberto, admite multiplicidades sem hierarquia. Modos de habitar no cinema são pontos de encontro. A construção de casas, moradas enquanto "topografias-ekphrasis" se constitui em uma interseção que instaura o habitar enquanto lugar narrativo: sua “dimensão material” se dá na confluência de imagens e sons, em formas arquitetônicas como fachadas, vãos, cômodos, mas também em seu interior, nos ínfimos objetos, em texturas e cores; sua "dimensão existencial” se figura diante do modo como personagens habitam os espaços em práticas que suscitam um sentido de vida cotidiana, de intimidade, de ações costumeiras. De todo modo, o habitar tem muitas conotações, e esta tese pretende investigar algumas delas.

\subsection{A arquitetura para dar suporte ao habitar no cinema}

Enquanto projeto, arquitetura e cinema se assemelham. Ao imaginar espaços, um projeto arquitetônico permite atribuições de sentido, articulações funcionais e elaborações formais. Desenhos em perspectivas, vistas, fachadas quando construídas tomam novos direcionamentos. Entregue àquele que o tomará para si, o espaço arquitetônico é impregnado de outros significados e novas relações. Sejam quais forem as ideias idealizadas anteriormente, viver neste espaço é percebê-lo de outro modo. Enquanto projeto, um filme traz ideias preconcebidas que articulam materialidades em um processo de criação exprimido em inúmeras fragmentações. O espaço cenográfico projetado responde a reinvindicações conceituais da narrativa e se transforma em plasticidades e espacialidades. Em suas concepções construtivas, arquitetura e cinema passam do abstrato ao concreto, e do concreto ao abstrato.

Para esta tese, parte-se da hipótese de que o encontro entre cinema e arquitetura acontece na interseção entre uma "dimensão material” do espaço, isto é, a concretude dos lugares identificados nas imagens e sons, e a abstração de um espaço imaginário erguido pelo espectador. Uma casa, ao ser construída em planos, enquadramentos e espacialidades 
fílmicas, abdica a uma suposta casa real e adquire autonomia, se constituindo em prol de uma narrativa específica, inserida em temáticas e contextos próprios. Ainda assim, para construir modos de habitar em narrativas cinematográficas de ficção, investe-se em uma metodologia transdisciplinar que reconhece nos estudos da arquitetura um caminho para dar suporte aos sentidos e percepções que se desprendem dos espaços de um filme.

A arquitetura sempre foi objeto de referência nas imagens cinematográficas, compreendendo um espaço específico pertencente aos filmes em geral. Casas, praças, ruas, edifícios são incorporados na construção de dimensões espaciais expostas na materialidade fílmica. Os espaços arquitetônicos apropriados pelo cinema acabam transformados. A partir da construção de um espaço diegético, e por meio de uma coesão entre elementos da linguagem presentes nos filmes de ficção, o cinema reconstrói prédios de recortes arquitetônicos, refaz percursos entre avenidas, recria interiores e exteriores, oferecendo novos sentidos a esses espaços. No cinema, a arquitetura se decompõe e se recompõe de outro modo. É uma outra arquitetura.

O cineasta e crítico de cinema Éric Rohmer, em sua análise do filme Faust de F.W.Murnau, reconhece o espaço arquitetônico como um dos três níveis espaciais de um filme. São eles: o espaço fílmico definido como o campo da dinâmica dos objetos no interior do quadro e do movimento da câmera que modifica o ponto de vista desses objetos; o espaço pictórico, que trata da imagem "percebida e apreciada como representação mais ou menos fiel, mais ou menos bela de tal ou tal parcela do mundo exterior" $^{56 "}$ (1977, p.11); e o espaço arquitetônico, "parcelas do mundo, naturais ou fabricadas, estão tomadas de uma existência objetiva e sujeitas a um julgamento estético. É a partir dessa realidade que o cineasta se avalia no momento da filmagem, restituindoa ou traindo-a" (ibidem).

Ao se apropriar de porções arquitetônicas, adaptá-las, ou mesmo recriá-las, o cinema redefine traçados e configura perspectivas do espaço arquitetônico. Não se trata apenas de um registro de uma obra arquitetônica, mas filmá-la exige construir lugares narrativamente. Espaços arquitetônicos são resgatados como cenários de filmes de ficção, evidenciando fronteiras entre ambos. Arquitetura e cinema criam espaços dinâmicos concebidos em contextos narrativos próprios.

No entanto, especialmente para o filme narrativo clássico visado "realista", a analogia entre os valores do lugar diegético e os do lugar

\footnotetext{
56 “[... ] perçue et appréciée comme la representation plus ou moins fidèle, plus ou moins belle de telle ou telle partie du monde extérieur". N.T.
} 
social geralmente será mantida. Ela funcionará, sobretudo, como princípio narrativo. Se servindo de meu conhecimento prévio, o filme irá utilizar o valor referencial dos lugares reais para provocar expectativas junto ao espectador $[\ldots]^{57}$ (ibidem, p.76).

Para Éric Rohmer, a arquitetura se assemelha às demais artes ao propor formas para se olhar: um edifício, um objeto, uma paisagem. A forma é sua parte visível, aparente em um filme. O espaço arquitetônico seria, então, o espaço pró-fílmico, aquele organizado na filmagem e manifesto no filme através de suas configurações aparentes, que deste modo, parece estar reservado a um papel secundário de cenário e decoração. No entanto, segundo Rohmer, ao ser tomado por sua funcionalidade, o espaço adquire um sentido de construção narrativa, impulsionando o personagem, seus gestos, suas emoções, seu destino. Os lugares "não se apresentam somente como o quadro da ação, seu receptáculo. Eles pesam sobre as atitudes dos personagens, influenciam sua atuação, ditam seus deslocamentos" ${ }^{58}$ (ibidem, p. 58). Uma casa é um espaço para morar, uma rua um espaço para trafegar, um aeroporto serve para viajar. Assim, ao espaço arquitetônico, agregam-se atribuições e funcionalidades, revelando a dramaticidade da cena e o tema explorado pelo filme.

A fronteira entre arquitetura e cinema, mais do que um embate entre cenário e elemento narrativo, impõe traçar delimitações entre a noção de espaço e lugar. André Gardies argumenta que o lugar é a realidade perceptível do espaço fílmico: "o lugar é um fragmento do espaço e o espaço é um conjunto de lugares" (1993a, p.68). Para ele, as imagens de uma rua, uma ponte, um edifício, são percebidas como fragmentos espaciais que reconstituem "esta espécie de totalidade chamada espaço" ${ }^{59}$. Deste modo, o lugar situado, particular, manifesto - alcança o espaço - geral, virtual, imaterial. O primeiro se define em suas particularidades, enquanto o segundo em sua organização.

O espaço diegético de um filme é um arranjo de lugares que são formas concretas dadas em imagens e sons tomados pelo espectador. A apreensão do espaço urbano se faz mediante uma avenida, edifícios, uma escola, uma praça, etc.; a percepção de um espaço doméstico se dá entre a fachada, as janelas, um quarto, uma cama; o espaço escolar se

\footnotetext{
57 “Toutefois, em particulier pour le film narratif classique à visée "realiste", l'analogie entre les valeurs du lieu diégétique et celles du lieu social sera le plus souvent maintenue. Elle fonctionnera même comme príncipe narratif. Jouant de mon savoir antérieur, le film usera de la valeur référentielle des lieux pour créer des horizons d'attente chez le spectateur [...]". N.T.

58 “[... ] ne se présentent pas seulement comme le cadre de l'action, son réceptacle. Ils pèsent sur les attitudes des personnages, infléchissent leur jeu, dictent leurs déplacements". N.T.

59 "Le lieu est um fragmente d'espace et l'espace um ensemble de lieux". N.T.
} 
reconhece em uma sala de aula, um quadro negro, algumas carteiras. Parece simples: o cinema emprega imagens concretas de lugares (ainda que construídos em estúdio ou digitalmente) que se definem por suas formas e funcionalidades, no entanto, o modo como esses espaços são narrados - cinematograficamente - desprendem outros sentidos, valorizando as particularidades de cada lugar e, ao mesmo tempo, a dinâmica da narrativa.

A geometria exposta nas obras arquitetônicas, suas verticalidades, seus ângulos, suas simetrias são assimiladas em propriedades e medidas cinematográficas. Isso implica uma reconstrução dessas edificações em novas espacialidades. Alinhamentos rigorosos são delineados por perspectivas, trabalhados em profundidade de campo, norteados na mise-en-scène de cada cena, emendados na continuidade de planos, combinados na ordem (ou desordem) das sequências de um filme. Aqui, a arquitetura se constrói na medida em que é explorada. $\mathrm{O}$ espectador, posicionado diante da imagem de um edifício qualquer, o toma para si. Do caos das grandes avenidas a alcova dos pequenos quartos, das galerias labirínticas aos edifícios abandonados, da permeabilidade dos vãos à transparência das janelas, os espaços arquitetônicos são apropriados pelo filme e edificados pelo espectador, passam de um a outro para narrar histórias. O espaço arquitetônico expressa dramaturgia, oferece ritmo e tensão às cenas narrativas.

Cada lugar afigurado em uma narrativa fílmica é portador de propriedades espaciais que o identificam e o caracterizam, confirmando ou confrontando sua indexação com o mundo real ou ainda propondo visibilidades para se perceber esse espaço. A forma, volume, proporções, ritmos, sons apreendidos na imagem de um lugar implicam no reconhecimento de seus valores sociais e culturais, definido por André Gardies (ibidem, p.77) como “força referencial do lugar”. No cinema realista, a força da ilusão referencial dos lugares é extremamente pregnante. Como levar em conta a força referencial do lugar, sem tender à analogia e aos estereótipos? A arquitetura e a noção de habitar oferece uma base para pensar este questionamento.

$\mathrm{O}$ arquiteto fenomenólogo Christian Norberg-Shulz propõe um retorno às coisas concretas do mundo da vida cotidiana, afirmando que não faz nenhum sentido imaginar um acontecimento sem fazer referência aos lugares. O lugar não pode ser reduzido a sua localização, muito menos à sua função pois, atividades básicas como dormir, comer, morar, solicitam lugares diversos, segundo diferentes costumes e condições. Sua proposta é perceber o lugar a partir de sua essência, definida como o "caráter do lugar", ou o "espírito do lugar" - o genius loci - que o identifica e o caracteriza. 
"Caráter" é um conceito ao mesmo tempo mais geral e mais concreto do que "espaço". Por um lado, indica uma atmosfera geral e abrangente e, por outro, a forma e a substância concreta dos elementos que definem o espaço. Toda presença real está intimamente ligada ao caráter. (2008, p.451)

Primeiro o lugar se define em coisas concretas (rua, casa, pátio, parede, porta), depois pelo seu caráter (aberto, horizontal, solene, protetor), em seguida, na relação que estabelece com outros lugares (abaixo, atrás, desde, perto). Se há um reconhecimento de seus elementos constitutivos, é necessário, do mesmo modo, que o lugar seja apreendido pela forma como é relacionado e vivenciado. No cinema, as coisas concretas são lugares construídos em imagens e sons que dão conta de um caráter que os identifica: uma janela alta, amarela e com o vidro quebrado; um edifício abandonado e silencioso; uma casa velha, suja e com uma antena parabólica; uma rua comprida e amedrontadora, um beco sem saída, etc. Porém, eles não se limitam a uma aparência física, não são apenas "vistas" que registram e descrevem a vida tal como ela é, são, concomitantemente, narrativas em movimento. Em filmes narrativos, importa o que Norberg-Shulz chama de "sistema de relações espaciais" indicado por preposições, semelhante à noção de relatos de espaço apresentada por Michel de Certeau (2009, p.182-198) ou ao conceito de topografia fílmica de André Gardies (1993a).

O espaço, como um sistema de relações, é indicado por preposições. No dia a dia, raramente falamos sobre "espaços', mas sobre coisas que estão "acima" ou "abaixo", "antes" ou "atrás" umas das outras, ou usamos preposições como "de", "em", "entre", "sob", "sobre", "para" "desde", "com", "durante". Todas essas preposições indicam relações topológicas do tipo mencionado acima (NORBERG-SHULZ, 2008, p.452).

Os espaços construídos nos filmes se expressam concretamente por lugares percebidos em visualidades e sonoridades, entretanto é na relação estabelecida com outros elementos espaciais que fazem avançar a narrativa. Volta-se aqui ao conceito de ekphrasis em que a apreensão do lugar não apenas veicula concretude e caráter, mas deflagra o modo como ele é narrado: integra o descritivo ao narrativo; é estagnação, mas também movimento; ora é "vista”, ora é "plano". Consolidando esse entendimento na realização de um filme, une o desenho do espaço proposto pela direção de arte com a mobilidade da mise-en-scène e da montagem.

Se por um lado a concretude dos lugares descreve e narra espaços em filmes ficcionais, de outro é preciso investigar as abstrações e imaterialidades que se resgatam 
desses lugares. Então, ainda se servindo da arquitetura para dar apoio ao estudo do espaço cinematográfico, investe-se nas reflexões interdisciplinares da pesquisadora Giuliana Bruno (2002) e do arquiteto finlandês Juhani Pallasmaa (2011, 2012). Ambos propõem que o cinema, como a arquitetura, é uma arte essencialmente espacial apoiada em experiências multissensoriais e incorporadas. Arquitetura e cinema criam cenários experienciais, despertam a memória e a imaginação, articulam o espaço vivido em imagens, mediam espacialmente uma essência existencial.

Giuliana Bruno, em seu livro Atlas of emotion: journeys in art, architecture, and film, transforma a figura do espectador de mero "voyeur" a possível "voyageur", e sua relação com o filme de "ótica" para "háptica”. Em seu argumento, "o gênero filmes-deviagem inscreve o movimento na linguagem cinematográfica, transportando o espectador para dentro do espaço". ${ }^{60}$ (ibidem, p.20). Ao avançar sua câmera pela cidade, o cinema propõe, ao espectador, viagens fundadas sob a emoção e a habilidade sensorial do corpo em se movimentar no espaço. A autora traça uma cartografia emocional entre a cultura da viagem, a arquitetura, a arte, e a imagem em movimento, fundando uma concepção moderna dos espaços a partir de experiências corporais de mobilidade.

De modo semelhante, Juhani Pallasmaa valoriza a dimensão do espaço vivido para pensar a experiência no cinema. O espaço vivido é uma combinação do mundo material percebido e do espaço construído mentalmente pela memória, pelo sonho, pelo imaginário. O lugar arquitetônico se valoriza não pela realidade que emana, mas pela capacidade de despertar a imaginação. Vivenciar espaços arquitetônicos e fílmicos constitui-se em experiências bastante semelhantes: ambas criam imagens de lugares em um modo cinestésico de vivenciar o espaço. Pallasmaa se serve da visão de Walter Benjamin $^{61}$ sobre o domínio táctil da arquitetura e do cinema, em contraposição à visualização da pintura, para afirmar que os primeiros são tomados pelo movimento incorporado, enquanto a pintura tem lugar por meio de uma ação idealizada.

Nós não vivemos separadamente em mundos materiais e mentais; essas dimensões experienciais estão inseparavelmente entrelaçadas. Nem vivemos num mundo objetivo. Vivemos em mundos mentais nos quais o experienciado, lembrado e imaginado, assim como o passado, presente, futuro estão misturados. [...] Os modos de experienciar a arquitetura e o cinema tornam-se praticamente idênticos neste espaço mental que serpenteia sem fronteiras fixas $(2012$, p. 89).

\footnotetext{
${ }^{60}$ The travel-film genre inscribed motion into the language of cinema, transporting the spectator into space". N.T

61 “A obra de arte na era de sua reprodutibilidade técnica", texto de Walter Benjamin publicado em 1955.
} 
Deste modo, aquele que usufrui de um espaço arquitetônico produz marcas em seu solo, adapta suas práticas em cômodos, amolda espacialmente suas lembranças. Uma obra arquitetônica provoca sensações e não é recebida igualmente por todos, mas apropriada de diversas maneiras. Ao mesmo tempo, uma obra cinematográfica convida o espectador a se posicionar como sujeito ativo capaz de entrar por uma porta, olhar através de uma janela, cruzar um vão, avançar uma rua, desviar-se de uma pilastra, dirigir-se a um terraço. A arquitetura se oferece como formas perceptíveis e experiência sensorial, transformando a narrativa em um percurso que vai de um lugar a outro como uma coreografia individualizada de movimentos, interagindo ações espacializadas e a fluidez da memória e da lembrança do espectador. "Uma rua num filme, não termina no canto do ecrã, ela prolonga-se, à volta do espectador como uma rede de ruas, edifícios e situações de vida" (ibidem, p. 92). Um quarto de aluguel, uma casa de periferia, um saguão de hotel, um muro alto, emolduram uma história, facilitam um encontro, separam amantes, unem desconhecidos, narram personagens e lugares.

Juhani Pallasmaa diz que todo filme contém imagens de arquitetura, seja por meio do "enquadramento de uma imagem ou a definição da escala ou ainda da iluminação" (ibidem, p. 91). Para o arquiteto, um mesmo acontecimento se transforma completamente em lugares diferentes. O cinema se serve disto para relacionar espaço, lugares, objetos e ações ditando a atmosfera e o tom de um filme e conduzindo personagens a seus destinos. Desde suas características plásticas até suas referências simbólicas, históricas, culturais, a arquitetura sugere diferentes formas de apropriação do espaço e é capaz de despertar a imaginação, criando situações cinematográficas tão reais quanto as vividas.

\subsection{Objetos e fragmentos narrativos}

Para pensar a arquitetura do cinema foi preciso investigar um entendimento de lugar, mas, do mesmo modo, despertar a imaginação a partir das pequenas porções arquitetônicas. $\mathrm{O}$ arquiteto italiano Marco Frascari escreveu um ensaio intitulado $O$ detalhe narrativo em que valoriza especialmente as junções entre materiais e espaços na construção arquitetônica. Sua análise reconhece os detalhes como "unidades mínimas de significação" na arquitetura. Para o autor, eles são elementos essenciais no ato de 
construir, pois edificam ao mesmo tempo, a construção material e a construção de sentido na obra arquitetônica.

$\mathrm{O}$ denominador comum nesses diferentes usos e formas sugere que o detalhe é uma expressão do processo de significação, isto é, a vinculação de significados a objetos feitos pelo homem. Assim, os detalhes são os loci de uma ordem do saber que a mente descobre sua própria inteligibilidade, isto é, seu logos (FRASCARI, 2009, p. 539),

Frascari refere-se à arquitetura como enredo e aos detalhes como narrativas. "A arquitetura é a arte da escolha apropriada dos detalhes para imaginar a história. Um enredo com detalhes apropriados desenvolve-se numa boa narrativa" (ibidem, p. 543). Uma história contada em detalhes instiga a memória e a curiosidade de seu leitor (espectador), concede autenticidade ao que está sendo narrado. Em um filme, as ínfimas particularidades descritas se desdobram em narrativas próprias que impõem ordem ao todo. Esses diminutos são também junções, integram as partes e formam o todo; transformam o "entre" em "e". A dobradiça fica no meio da porta, dobra o fora para dentro e vice-versa; entre o exterior e o interior está a janela, a porta e a soleira, unem a casa e a rua; o corredor está entre o quarto e a cozinha, leva um a outro. A arquitetura se ergue em detalhes, enquanto o cinema se decompõe em fragmentos: edifícios e filmes se igualam nos pormenores.

O espaço e seus lugares, em um filme de ficção, emergem no encontro de personagens e coisas. As miudezas não estão presentes apenas para compor uma cenografia, são sensibilidades em torno das quais se organizam as narrativas cotidianas, oferecem referências e autenticidade às histórias narradas. As miudezas são detalhes que ora passam desapercebidos, ora atraem a atenção para sua concretude. Em suas análises fotográficas, Roland Barthes reconhece o detalhe significativo (punctum) como um "suplemento" que fixa o olhar sob um gesto, um objeto, um pormenor em uma fotografia: “Nesse espaço [...], um 'detalhe' me atrai. Sinto que basta sua presença para mudar minha leitura, que se trata de uma nova foto que eu olho, marcada a meus olhos por um valor superior" (1984, p. 68). Ao se sentir atraído por um pormenor, Barthes desprende de uma fotografia um espaço extracampo que o leva a uma elaboração mental, sensível.

Ao mesmo tempo, em sua análise sobre obras de Gustave Flaubert e Julet Michelet, os objetos barômetro e porta presentes nos textos literários assumem o papel de detalhes supérfluos, "inúteis", "insignificantes”, que pouco acrescentam à estrutura narrativa, dando conta apenas do efeito do real: "o barômetro de Flaubert, a pequena porta de Michelet, não dizem mais nada que isto: somos o real; é a categoria do "real" (e não 
seus conteúdos contingentes) que é então significada; ... produz-se um efeito de real [...]" (BARTHES, 1972, p. 43). Ao tratar dos pormenores como detalhes irrelevantes ou de “enchimentos", Barthes reduz a descrição à aparência e o realismo à superficialidade.

Na constituição de espaços de um filme de ficção, há certa diferenciação entre os objetos que irão compor um ambiente e aqueles, aparentemente mais relevantes, que participarão da narrativa e da ação, tomando certo destaque dentre os demais. Objetos comuns - chaves, ferramentas, malas, caixas, fotografias - podem assumir o lugar de um protagonista e conduzir a narrativa fílmica. Às particularidades visuais de um objeto agregam-se valores que amplificam sua relevância na relação com o universo do personagem, passando de "simples objeto" a "sujeito ativo" com trajetória particular, imprimindo ritmo e dramaticidade à narrativa. Os pormenores dos filmes de ficção explicitam um contexto situacional, mas também identitário e simbólico. As minúcias revelam o mundo íntimo dos personagens, seus desejos, seu caráter, mas também possibilitam acessar abstrações.

Em um filme, a presença de um objeto se modifica segundo o enquadramento de sua imagem. Um objeto qualquer inserido em um plano conjunto ${ }^{62}$, em que se privilegia a paisagem ou um ambiente, figura como um pequeno detalhe, uma porção menor inserida em um contexto maior. O objeto representa um diminuto de uma completude, uma pequena parte de um todo, e por isso, passa desapercebido. Todavia, ainda no mesmo plano conjunto, associado a outros objetos, impõe ordem, equilíbrio, complexidade (ou desordem, instabilidade e simplicidade) ao cenário e colabora na construção de sentido e identificação do caráter do lugar: uma sala assimétrica e bagunçada, um quarto minimalista, uma cozinha organizada e bem equipada.

O mesmo objeto figurado em um plano detalhe $e^{63}$ se destaca e expõe seus próprios detalhes. Ele cresce e aparece, passa de pano de fundo a protagonista, vira um todo maior. É plano conjunto, tem textura, cor, volume, suas próprias visualidades (simetria, equilíbrio, regularidade, ritmo...); tem concretude, é também lugar. Em seu livro Paisagens Urbanas, o arquiteto Nelson Brissac Peixoto relaciona o close up à paisagem. Esse plano "isola detalhes - rostos, objetos - do seu ambiente, forçando-nos a vê-los na sua opacidade e no seu mistério, carregados de significações imperceptíveis no tecido cotidiano" (2003, p. 72). Não seria apenas o olhar aproximado, mas o enquadramento

\footnotetext{
${ }^{62} \mathrm{O}$ plano de conjunto apresenta os personagens de corpo inteiro revelando uma parte significativa do cenário em que estão inseridos.

${ }^{63}$ Plano aproximado que revela as parcelas do corpo ou detalhes de objetos, como superfície, cores, texturas e outras particularidades.
} 
limitado pelas bordas da imagem convertido em intimidade. Diz também Gaston Bachelard que cada "objeto investido de espaço íntimo transforma-se em centro de todo o espaço" (2003, p. 207). Um objeto em plano detalhe transforma o olhar do espectador sobre o real, revela possibilidades outras para se acessar a existência mundana. Leva o cinema às práticas cotidianas: abrir (a janela), fechar (a tampa), pegar (a colher), trocar (a lâmpada), movimentos diários que no espaço vivido passam como num segundo, quase invisíveis, mas em plano detalhe, em um filme, em uma observação aprofundada e cuidadosa, fundamenta o mundo íntimo como evidência de nossa existência.

Em filmes do gênero do cotidiano, o reconhecimento da essência de um lugar advém da análise dos fenômenos do mundo da vida cotidiana. Do mesmo modo, os pormenores arquitetônicos se relacionam em um todo unificado, concretizando o lugar a partir de coisas concretas e de experiências vividas concretamente. Marco Frascari (2009) diz que a escolha dos detalhes na arquitetura define o caráter de um edifício, viabilizando a relação entre o dentro e o fora, entre os cheios e os vazios. Pessoas, ruas, prédios compõem nosso dia-a-dia, mas também portas, janelas, soleiras e maçanetas. A porta abre e fecha, porém é a maçaneta que permite confrontar o dentro e o fora. $\mathrm{O}$ armário organiza, divide, separa objetos, mas é a gaveta que oferece a propriedade básica do objeto privado.

O cineasta francês Robert Bresson diz sobre a fragmentação: “ela é indispensável se não se deseja cair na representação. Ver os seres e as coisas em partes separadas. Isolar estas partes. Torná-las independentes a fim de dar a elas uma nova dependência” (1988, p.93 $)^{64}$. Uma cidade é uma cidade, mas, ao ser vista de perto, o que se apreende são fragmentos: bairro, rua, loja, mercado, ônibus, casa, árvore, piso, pedra... No ambiente reservado de uma casa há o quarto, espaço de recolhimento, que abriga a cama, lugar de intimidades e sonhos, que oferece a coberta, objeto de proteção e resguardo. Há sempre um "muito pequeno" inserido no "pequeno", e o cinema - com o plano detalhe, o close, o big-close - nos leva ainda mais a esses diminutos. O cinema do cotidiano apreende a materialidade do espaço vivido (lugares e objetos) não como representação de coisas reais, mas em fragmentos tomados em uma vinculação narrativa proporcionada em um "modo aproximado" que demuda nossa percepção da vida cotidiana.

Giuliana Bruno (2002) transforma o espectador-voyeur em espectador-voyageur, defendendo a mobilidade como acesso ao gênero "filmes-de-viagem", e esses como

\footnotetext{
64 "Elle est indispensable si on ne veut pas tomber dans la représentation. Voir les êtres et les choses dans leurs parties séparables. Isoler ces parties. Les render indépendantes afin de leur donner une nouvelle dépendance". N.T.
} 
passagens para a experiência cinética da vida moderna, mas nesta tese, o espectador não é observador ou visitante, mas criador de territórios, não em um sentido de dominação e sim de apropriação. $\mathrm{O}$ acesso ao universo do cotidiano nos filmes de ficção acontece nas ações dos personagens, mas também nos lugares e objetos do dia-a-dia percebidos em imagens e sons. O espectador é aquele que se apropria dos lugares e dos objetos cotidianos, vivenciando e se emocionando com as imagens e os sons de um filme, experienciando o mundo ficcional como as experiências das coisas mundanas. Ao transpor o espaço fílmico, fornece memórias, lembranças, conhecimentos e emoções, habitando imagens e sons. E ao habitar, integra filme e vida cotidiana, abstração e concretude, cinema e arquitetura.

Juhani Pallasmaa alega que não é a obra de arte que oferece emoções ao espectador, mas sim é a obra quem "recebe as emoções do espectador e devolve-as. A obra de arte não reflete os afetos do artista; o espectador/leitor empresta as suas próprias emoções à obra. Quando experienciamos uma obra de arte, projetamo-nos no objeto da nossa experiência" (2012, p.97). Observadas pelo ponto de vista do filme, o cotidiano, seus lugares, suas coisas mundanas confrontam a vida ordinária do personagem com o mundo íntimo do espectador. Vistas sob o olhar do espectador, o filme o posiciona diante de seus próprios dramas, de sua condição humana, de suas desventuras cotidianas.

O grande mistério do impacto artístico é que um fragmento é capaz de
representar um todo. [...] O leitor constrói um edifício ou uma cidade a
partir das sugestões do escritor e o espectador de um filme cria uma
época inteira a partir das imagens fragmentadas fornecidas pelo
realizador (PALLASMAA, 2012, p.97).

Cinema e arquitetura valorizam o poder da experiência no espaço para conceber filmes como experiências multissensoriais. Ao tomar as vivências práticas e emocionais da vida cotidiana no espaço real, a partir da relevância dada a objetos e lugares, viabilizase a vida cotidiana não somente em sua banalidade diária, mas em um engajamento de espacialidades cinematográficas. Se pelo movimento do corpo, o homem apreende pequenos objetos e se apropria do espaço arquitetônico, no cinema retoma suas vivências em imagens e sons para construir espaços fílmicos pleno de sensações e percepções. Nas narrativas ficcionais do cinema mundial, personagens, objetos, lugares se entremeiam, situando o espectador no âmbito de experiências cotidianas, deixando-o habitar seus espaços. 


\subsection{Personagens e modos de habitar}

Se nos capítulos anteriores, um entendimento de topografia e a concretude de lugares e objetos apareceram como suporte para erguer modos de habitar que abarcam concomitantemente a fragmentação espacial e a percepção do espaço como totalidade, interessa-nos agora uma dimensão que se constitui como espaço habitado. Investe-se, então, na hipótese de dois percursos imbicados na relação entre espaço e personagem: um segue um contexto situacional, afirmando o espaço narrativo como um percurso de orientação dos personagens, o outro se dá na contrapartida de contexto de identificação que evoca o mundo íntimo do personagem e seu elo com um possível universo compartilhado com demais personagens. Em ambos, um questionamento em torno do habitar como referência para pensar a relação entre protagonista-cosmopolita e espaço habitado se pontuou norteador desta investigação.

A busca de um entendimento para modos de habitar se inicia junto a abordagens fenomenológicas que analisam o termo habitar, não apenas como sinônimo de residir, mas como um modo de estar e permanecer no espaço vivido. Conforme Martin Heidegger, quando "se fala em habitar, representa-se costumeiramente um comportamento que o homem cumpre e realiza em meio a vários outros modos de comportamento" (2008, p.127). Sua tese se fundamenta em uma ontologia existencial caracterizando o homem como um "ser-no-mundo", isto é, alguém que habita um mundo. Em sua obra o filósofo Ser e tempo (2005a, 2005b), investiga o sentido de ser-em:

O que diz ser-em? De saída, completamos a expressão dizendo: ser "em um mundo" e nos vemos tentados a compreender o ser-em como um estar "dentro de..." Com esta última expressão, designamos o modo de ser de um ente que está num outro, como a água está no copo, a roupa no armário. Com este "dentro" indicamos a relação recíproca do ser de dois entes extensos "dentro" do espaço, no tocante a seu lugar neste mesmo espaço. Água e copo, roupa e armário estão igualmente "dentro" do espaço "em" um lugar (HEIDEGGER, 2005a, p.91).

A preposição "em" introduz, aqui, uma designação de lugar, um "ser-em-ummundo", ligando o ser a um mundo, isto é, vinculando o homem a um espaço. Heidegger aproxima a preposição “em” a morar, habitar, deter-se; o mundo é o contexto em que o ser habita, isto é, a casa onde habita; enquanto ser leva à expressão eu sou como existência mundana relacional: morar junto a, ser familiar com (ibidem, p. 92-105).

Definir o homem como um "ser-no-mundo" pressupõe um dentro, isto é uma 
interioridade, um espaço pessoal, um mundo íntimo, ao mesmo tempo em que implica em uma alteridade, um encontro com o outro. Portanto, o modo de estar e permanecer no espaço pressupõe uma interioridade e uma exterioridade, um espaço de confinamento e outro de compartilhamento.

Existe aqui uma preocupação em analisar os sentidos que se desprendem da palavra "habitar" e a maneira pela qual as narrativas fílmicas constróem diferentes modos de habitar em imagens e sons. Os personagens ficcionais não existem de forma isolada, existem em correlação com os lugares os quais estão inseridos e com os demais personagens da narrativa. Se a preposição "em" conduz a "dentro de", isto é, "um ente que está num outro", abarca-se, para fins desta pesquisa, uma espécie de mutualismo entre personagem e espaço. O “dentro” do qual nos fala Martin Heidegger (2005a) não se limita ao copo como recipiente e a água como conteúdo, seu entendimento de habitar implica uma inter-relação entre mundo e ser, de tal forma que a falta de um põe em risco a permanência do outro. Nessa situação de mutualismo, a existência de um incide na existência do outro, a evolução de um depende da evolução do outro, o que nos abre um trajeto para seguir à procura desses modos de habitar no cinema: partir ao encontro de homens da contemporaneidade, de protagonistas-cosmopolitas, investigando suas moradas.

Essa busca se dá levando em conta a premissa de que o mundo urbano impõe a seus habitantes, situações vividas não apenas na cidade, mas no âmbito da domesticidade. Das várias conotações da palavra habitar, reconhece-se seu significado próximo a espaço doméstico e ao ato de morar, residir em algum lugar. Morar, em sua origem etimológica, significa demorar, ficar, retardar-se. A moradia é determinante para preservar a vida privada e afetiva, todos necessitam de um local para morar como condição humana básica da sobrevivência no cotidiano. Nesse entendimento, o caráter de lugares para habitar se concretiza em espaços de moradia, domicílios, residências. Residir é definido como o ato de se estabelecer em algum lugar, um modo de estar ou demorar-se localmente, o que impõe uma ideia de permanência. A associação sugere uma noção de habitar com referências a um ponto fixo, estável. Em tempos de fluidez e mobilidade exacerbada, há como pensar em modos de habitar fundamentados em um caráter fixo e permanente ${ }^{65}$ Como identificar homens cosmopolitas desde os lugares os quais habitam?

\footnotetext{
${ }^{65}$ Para responder ao questionamento, sugere-se a pesquisa de Marta Bogéa, Cidade errante: arquitetura em movimento (2009), que investiga uma arquitetura em conformidade com o caráter nômade da modernidade, submetendo a cidade e seus edifícios à mobilidade e fluidez dos novos tempos.
} 
Em filmes do gênero cotidiano, os personagens habitam em algum lugar, isto é, as narrativas de uma vida cotidiana se apoiam em ações diárias localizadas (comer, dormir, trabalhar...), e habitar é uma delas. As características de um personagem não são definidas apenas pelo figurino e pelos aspectos físicos evidentes, seu "modo de ser" pressupõe uma relação com o ambiente, implicando um direcionamento e organização espacial. Segundo Christian Norberg-Schulz,

Quando o homem habita, está simultaneamente localizado no espaço e exposto a um determinado caráter ambiental. Denominarei de "orientação" e "identificação" as duas funções psicológicas implicadas nessa condição. Para conquistar uma base de apoio existencial, o homem deve ser capaz de orientar-se, de saber onde está. Mas ele também tem de identificar-se com o ambiente, isto é, tem de saber como está em determinado lugar (NORBERG-SCHULZ, 2008, p. 455).

A visão do arquiteto sugere uma reflexão sobre modos de habitar em filmes de ficção com base na identificação e orientação, onde o lugar adquire valores em função da presença do personagem (ou personagens), seja para situá-lo, seja como ambiente para suas práticas, seja como elemento narrativo provocador de suas ações, ou ainda como indicativo de suas características sociais e psicológicas. Os modos de ser, estar ou percorrer o espaço se constituem como elemento narrativo apoiado em um mutualismo entre personagem e espaço: a identificação de personagens cosmopolitas consiste no reconhecimento de suas moradas; sua orientação no espaço narrativo acontece em uma dinâmica que se dá entre dimensões espaciais e personagens. Em um filme, cada personagem ocupa um lugar único alcançado por meio da orientação e identificação em uma topografia que lhe é própria.

Edifícios, prédios, habitações são os lugares de um universo urbano ficcional, mas também avenidas, caminhos, vias, ruas, consentindo relações diversas numa construção permanente. A organização espacial compõe uma trama espacial constituinte da narrativa que implica em uma orientação do personagem no interior do espaço fílmico. Cada espaço sofre a influência do outro, pressupondo modos diferenciados de espacialidades e mobilidades: a estrada conduz à cidade, as ruas levam aos edifícios, a porta se abre para rua. Se por um lado, lugares são espaços localizados e demarcados por uma noção de fixidez, como um edifício ou uma casa, por outro, caminhos, rodovias, ruas, corredores provocam o deslocamento e a cinesia dos personagens. Nesses espaços, eles circulam, transitam, atravessam corredores, linhas de metrô, caminhos, rodovias, seguindo seus percursos, sendo conduzidos de um ponto a outro, se movimentando entre lugares. Espaços de trânsito ou de passagem são "espaços-ligação", termo conceituado por André 
Gardies (1993a, p.115) para definir trajeto, percurso e itinerário apreendidos segundo o deslocamento de personagens e a funcionalidade dos espaços em um filme.

Mapeadas em "pontos e linhas", as narrativas do cinema contemporâneo orientam o fluxo de personagens cosmopolitas que se deslocam o tempo todo, apontando para a instabilidade e a não permanência, colocando em xeque um sentido de habitar como espaço fíxo e estável. Se por um lado Giuliana Bruno atenta para os "filmes de viagem" como provocadores de experiências de mobilidade, a pesquisadora Andréa França (2003) reconhece, nos "filmes de fronteira", espaços de passagem evidenciados em imagens de nomadismo e imigração, afirmando "que as identificações imaginárias que os filmes oferecem como experiência estética e política, estão intimamente vinculadas ao modo como os espaços são percorridos" (2003, p.36). França (ibidem, p.55) cita o entendimento de prática de espaço em Michel de Certeau para ressaltar filmes que exploram o caráter itinerante dos personagens, articulando-o em seus temas e conteúdos.

Certeau reconhece dois modos para se praticar o espaço de uma cidade: o primeiro seria cometido pelos voyeurs que apreendem a cidade pelo prazer da visão e a imobilizam enquanto cidade-panorama; o segundo é perpetrado pelos caminhantes que transformam a cidade, apontando atalhos e desvios, criando "uma organicidade móvel do ambiente" (2009, p. 165). Em filmes de ficção, os personagens tomados como voyeurs ocupam um lugar passivo e se submetem às imposições formais dos espaços: uma casa é uma casa, uma rua é "espaço-ligação", um corredor é passagem, o quarto é para dormir, um carro serve para se transportar. Já os caminhantes não se prendem a determinações, quebram algumas barreiras e concebem outras permeabilidades. $\mathrm{O}$ "caminhante transforma em outra coisa cada significante espacial”, afirma Michel de Certeau (ibidem).

Em filmes do gênero cotidiano do cinema contemporâneo, o protagonistacosmopolita é também "caminhante", se apropria dos espaços e os transforma. Vale lembrar que os cosmopolitas não residem, se localizam temporariamente; se acomodam de modo provisório; suas práticas não têm local certo; invadem lugares e se apropriam deles; não se submetem às regras do lugar, propõem mudanças; reconstroem espacialidades; reinventam práticas de espaço, improvisam; ocupam espaços intervalares. E se a identificação dos personagens consiste no reconhecimento de seus modos de habitar, o espaço aqui é também mutante, se adapta, transmuta, se ergue no encontro com o protagonista: em um filme, a casa é jardim, no outro um carro; na confluência com um personagem, o hotel, a rodoviária e o aeroporto deixam de ser espaços de passagem e se 
transformam em residências; o quarto vira prisão, a poltrona apropriada se torna cama, o corredor é ambiente de confissões, a rua, um lugar para se amar.

As narrativas do cinema renovam as experiências nos espaços, não somente pela mobilidade e itinerância de seus personagens, mas pela transitoriedade de modos de habitar o espaço urbano plenos de incertezas e provisoriedades. Este trabalho procura evidenciar elementos comuns em modos de narrar esses novos espaços reconhecidos em uma noção transitória de vida cotidiana. "Transitório" deriva do latim transitorius ${ }^{66}$, significando uma passagem, ou alguém que está de passagem. A palavra abarca também a transição não somente como algo passageiro ou provisório, mas em uma noção de espaço intervalar, um "entre", um lugar que se reconhece como interseção entre uma coisa e outra, algo que não é determinado, fixo, mas construído em nuances e não em dicotomias rígidas. Os modos de habitar transitórios oferecem ao espectador experienciar entre-lugares, seja na percepção de lugares que adquirem novos sentidos e funcionalidades ao ser apreendidos por protagonistas-cosmopolitas, seja por um cinema que propõe novos modelos narrativos para pensar as mobilidades e transitoriedades da vida contemporânea.

A noção de habitar pressupõe uma identificação e uma orientação, mas associada às dinâmicas da contemporaneidade, assinala modos de habitar transitórios apreendidos entre espaço e sujeito. Stuart Hall (2000) reconhece a mudança de um sujeito centrado, possuidor de uma identidade unificada e estável, para um sujeito da pós-modernidade descentrado e possuidor de identidades múltiplas. Hall prefere a palavra identificação à identidade, pois essa se reduz a algo determinado, enquanto aquela indica um processo em andamento, um trânsito de identidades em constante mudança. A globalização provoca uma "celebração móvel" de identidades, deslocando o sujeito tanto de seu lugar como de si mesmo. Cada identidade 'tem suas 'paisagens' características, seu senso de 'lugar', de 'casa/lar'” (ibidem, p. 71), ao se deslocarem, deslocam os lugares e suas práticas específicas. Para sujeitos deslocados, o sentido de habitar se molda sobre novas articulações.

Nos filmes selecionados para fins desta pesquisa, há um bom número de personagens deslocados de seu lugar, um pouco desorientados, que se movem à deriva, sem saber muito para onde ir. Eles deixam-se levar, estão aqui, mas também ali, presentes

\footnotetext{
${ }^{66}$ Disponível em <http://www.lexilogos.com/latin/gaffiot.php?q=transitorius+> Acesso em: 11 fev 2013.
} 
em um lugar desejam estar em outro: Charlotte é americana e mora em Tóquio por imposição do marido, passa os dias andando à deriva na nova cidade (Encontros $e$ desencontros, 2003); Jun é chinês e mora de passagem na casa de Roberto que não vê a hora de sua partida ( $O$ conto chinês, 2011); Jia retorna à China para cuidar dos pais idosos, mas gostaria de estar em sua casa na Nova Zelândia ( $A$ casa vermelha, 2012); Louise vive em seu carro porque não tem onde morar (Louise Wimmer, 2012); Alejandra é uma jovem de 15 anos que, após a morte de sua mãe, se vê obrigada a residir com o pai na cidade do México e a conviver com a hostilidade dos novos colegas de escola (Depois de Lúcia, 2012); habitante de um bairro da periferia de Paris, Juliette ocupa sua vida cuidando dos filhos, mas não se sente à vontade em seu lugar (La vie domestique, 2013);

Como Charlotte, Jun e Louise, tantos outros protagonistas-cosmopolitas do cinema contemporâneo se encontram "des-centrados", “des-amparados”, “desorientados" ..., e deslocados, "deslocando também os lugares e suas práticas específicas". Habitam em lugares de passagem, ambientes precários, alocam-se na casa de outros, acomodam-se em "espaços-ligação", dormem em espaços de trânsito. O prefixo "des" admite uma margem para pensar o habitar em um caminho de negação, um "des-habitar", quem sabe um "des-território" ou uma "des-casa”, mas é explicitado aqui como "um outro modo para se perceber uma casa". O sentido de desterritório é uma ausência de território, não no sentido de perda de domínio, mas na falta de um vínculo entre espaço e sujeito, em um estado de "des-pertencimento".

Os cosmopolitas edificam lugares com certo desprendimento e algum despertencimento. Recorre-se, então, à noção de multiterritorialidade para dar conta da diversidade de modos de habitar que se erguem diante do desenraizamento de homens que se deslocam o tempo todo, frente a uma desterritorialização generalizada, ou à diluição de fronteiras e nações. Mais do que um espaço de dominação, a questão do território nos filmes de ficção passa pela construção de espaços apreendidos de modo diferenciado por cada filme e cada personagem.

Se no campo da Etologia, o território define-se entre dominação e apropriação territorial a partir dos estudos dos hábitos de espécies animais, aqui, toma-se território como um conceito fugidio em um atravessamento de seu potencial expressivo e imaginativo. Com Henri Lefebvre, o espaço apropriado se dá em oposição à ideia de espaço dominado (propriedade). O espaço dominado é geralmente fechado, estéril e vazio. “Quanto mais o espaço é funcionalizado, mais ele é dominado pelos 'agentes' que 
o manipulam tornando-o unifuncional, menos ele se presta à apropriação"67 (2000, p. 411412). Michel de Certeau, também, reflete sobre o espaço apropriado, igualando-o a "lugar praticado". "Em suma, o espaço é um lugar praticado. Assim a rua geometricamente definida por um urbanismo é transformada em espaço pelos pedestres" (2004, p.184). Ao ser apropriado, o lugar é transformado.

A noção de espaço apropriado e lugar praticado nos leva a pensar o espaço fílmico como lugar habitado, instaurando uma relação singular entre personagem e mundo ficcional. Se o espaço toma sentido quando apropriado pelo personagem, a representação de um espaço qualquer em narrativas ficcionais como uma casa será sempre relativa. Os novos modelos narrativos do cinema do cotidiano mais do que amoldar os lugares a funções pré-concebidas, questionam suas possibilidades expressivas, buscando um princípio de multiplicidade para se fundar territórios em imagens e sons.

O ambiente de uma casa ou de um "espaço qualquer" se estrutura aos poucos pela narrativa fílmica em fragmentos de imagens, mas é a apropriação desses lugares pelos personagens, em suas práticas de espaços, que constroem espacialidades e criam espaços narrativos nas histórias contadas. Um movimento de aproximação, um trajeto seguido, um pequeno objeto sendo pendurado, uma chave girando, uma janela que se abre para uma paisagem, um modo de comer e de se sentar ao lado de alguém, a forma de adentrar a um quarto com certa hesitação..., ao se apropriarem dos espaços, os personagens fazem dos lugares seus territórios. Há, aqui, um interesse na constituição do universo particular de um personagem, e mais ainda, do mundo íntimo de um protagonista-cosmopolita apreendido em espacialidades repletas de transitoriedade.

Representar uma casa, uma residência, em um sentido de território em narrativas do cotidiano ratifica a morada na apropriação dos espaços domésticos assumida como práticas de espaço. Para Michel de Certeau, as práticas são inventoras de espaços (ibidem, p.174). São elas que interceptam espaço e sujeito, possibilitam o "ser-aí" e tornam o habitar presente. O habitar sugere um enraizamento do sujeito em práticas de espaços, mas esse habitar é transitório, se dá no movimento, na instabilidade. Hoje, uma casa como espaço para habitar não pode mais ser construída em vigas, paredes, telhado, portas e janelas, mas sim em práticas cotidianas: cozinhar, comer, dormir, e mais ainda, construídas em deslocamentos constantes, só são apropriadas em formas concretas como escova de dente, garfo, prato, travesseiro. O quarto é se apropriar de um travesseiro e se

\footnotetext{
67“Plus um espace est fonctionnalisé, plus il est domine par les 'agents' qui l'ont manipule em le rendant unifonctionnel, moins il se prête à l'appropriation". N.T.
} 
encostar, o armário é uma mala pequena com poucas roupas, a sala de jantar, um alimento bem acondicionado no fundo da bolsa.

\section{COSMOPOLITAS E MODOS DE HABITAR TRANSITÓRIOS}

Em se tratando de uma pesquisa pautada em filmes de ficção do cinema mundial, realizar um recorte temporal que facilitasse a construção do corpus se fez necessário. Nesse sentido, foi elaborado um quadro ${ }^{68}$ contendo aproximadamente cem filmes narrativos de ficção, com lançamento comercial nos últimos dez anos e de nacionalidades diversas, que exploram temáticas urbanas da vida cotidiana na sociedade contemporânea. $\mathrm{Na}$ ânsia de encontrar lugares reconhecidos como modos de habitar, buscamos filmes pertencentes ao gênero cotidiano que se apresentam como objetos empíricos para fins de nossa análise. Vale lembrar que o "cotidiano refere-se à intimidade, aos modos de vida, ao dia-a-dia da existência privada, familiar, pública, às formas de transmissão dos costumes e dos comportamentos" (NOVAIS, 1997, p.8). Os filmes selecionados expõem práticas e ações cotidianas retratadas espacialmente em narrativas cinematográficas. Alguns gêneros cinematográficos e categorias de filmes foram deixados de lado neste trabalho. Dentro da categoria de ficção, os gêneros ${ }^{69}$ fantástico, ficção científica, musical, terror, faroeste, além de filmes épicos e os que se passam no meio rural, mas também o Cinema de Animação, o Cinema Experimental e o Cinema Documentário não foram considerados para fins desta pesquisa.

Poderíamos ter começado essa busca, averiguando a filmografia de um único cineasta e sua maneira de colocar em cena o homem cosmopolita, porém procuramos investigar os diferentes modos de habitar o espaço urbano a partir da visão de diferentes cineastas da cinematografia mundial atual. Não buscamos filmes que exponham discursos globalizados e que falem por todos, mas narrativas que se conduzam em suas singularidades em uma perspectiva mais global direcionada para questões relacionadas à nossa urbanidade no estabelecimento de novas fronteiras em um mundo contemporâneo que não para de se movimentar. Analisar filmes do cinema contemporâneo mundial é investigar imagens e sons em um discurso de mundo globalizado, ao mesmo tempo em que se atenta para certo comprometimento com retratos fílmicos íntimos centralizados

\footnotetext{
${ }^{68}$ Quadro apresentado em anexo.

${ }^{69}$ A classificação dos gêneros cinematográficos foi utilizada aqui de forma simplificada a partir dos estudos Raphaëlle Moine, em seu livro Les genres du cinéma (2005), que procura pensar o termo dentro de toda sua complexidade.
} 
em uma vida cotidiana que poderia se passar na cidade de Tóquio, Buenos Aires ou São Paulo.

Da filmografia selecionada, destacamos, em um primeiro momento, os espaços narrativos centrais de cada filme, identificando locais urbanos diferenciados como casas, escolas, restaurantes, hotéis, galerias, aeroportos, lojas, postos de gasolina, entre tantos outros. Para a demarcação do corpus, e na tentativa de encontrar os espaços domésticos de personagens cosmopolitas, foi preciso reconhecer nos filmes, espaços que continham um sentido de habitar próximo à residência ou morada.

De todos os lugares representados nas narrativas fílmicas e percebidos como espaços domésticos, a casa apareceu como o mais frequente. Muitos personagens habitavam em casas tradicionais (incluído aqui os apartamentos), no entanto outros locais destinados a usos e funções diversas (como hotéis, galpões, aeroporto, posto de gasolina e até mesmo carros) manifestaram em sua concepção a ideia de espaço de moradia. Por um lado, a constituição desses lugares afirmava o habitar, o morar, como uma ação bastante presente em narrativas do cotidiano: em filmes do gênero cotidiano, os personagens habitam ou necessitam habitar em algum lugar. Por outro, a presença de lugares que assumem a função de habitar aponta para um questionamento da própria noção de casa. As narrativas íntimas nos conduzem a interrogar a dimensão da casa como lugar central de uma vida rotineira, plena de intimidades e familiaridades, e de cogitar outros modos de habitar que reconfiguram a casa como espaço narrativo para representar as práticas de residir e morar em filmes de ficção.

A presença de espaços diferenciados para habitar, identificados nos filmes elencados, revela muito sobre as dimensões espaciais em que transitamos nos dias atuais. Refletir acerca do espaço e sua categorização no mundo de hoje talvez seja uma boa maneira de entender um pouco mais de nossa efêmera existência. Ao mesmo tempo, a construção de um espaço de autoconhecimento convém como referencial para uma maior identificação entre o público e o cinema contemporâneo. A casa que moramos é também a casa percebida no cinema.

Uma primeira dificuldade encontrada ao se debruçar sobre o corpus incidiu em encontrar categorias de análise que abarcassem a grande multiplicidade de casas e residências constituídas no cinema ficcional como espaço narrativo característico de uma vida cotidiana. Algumas tentativas foram feitas: a primeira buscou conceber o espaço da casa a partir da relação fundada entre os personagens: são casas invadidas, casas compartilhadas, casas paternas. Nessa categoria, evidenciam-se filmes que exploram a 
temática da invasão de privacidade a partir do espaço da casa, a casa como espaço de convivência entre personagens de diferentes nacionalidades, ou ainda a casa tomada enquanto espaço de conflito entre pais e filhos.

Essa possível classificação dos filmes permitiria reconhecer instâncias narrativas para pensar uma noção de casa, contudo, ficariam excluídos outros lugares que também se instituem narrativamente como moradas urbanas no cinema contemporâneo: os espaços de tráfego que assumem provisoriamente a função de lar como estações rodoviárias, terminais de aeroportos, portos ou até mesmo supermercados; os hotéis apreendidos como residências, questionando seu sentido estereotipado de lugar transitório; as casas confrontadas e desestruturadas pelas dinâmicas do mundo urbano, contrapondo o espaço privado do ambiente doméstico e o espaço público externo. Em nossa amostra de filmes, os locais improvisados tomados como residências precárias para personagens à margem da sociedade também se revelaram problemáticas igualmente relevantes a serem investigadas neste trabalho. Enfim, eram muitos caminhos a seguir para se chegar a um entendimento de modos de habitar transitórios na contemporaneidade a partir de filmes de ficção do cinema mundial. Essas narrativas nos forneceram uma profusão de casas, residências, habitações, entre outros espaços narrativos sujeitos a enlouquecer qualquer um que ensaiasse igualá-las ou inseri-las em algum tipo de categorização. Talvez enquadrá-las não é suficiente para abarcar sua diversidade, ou quem sabe filmes sejam unidades incompatíveis com toda forma de categorização.

Posto de lado esse primeiro recorte, encontramos filmes de cineastas de diferentes nacionalidades centrados em temáticas relacionadas à vida cotidiana apoiadas em questões sociais da contemporaneidade, histórias inseridas em ambientes urbanos e agenciadas por ações protagonizadas por personagens caracterizados como homens comuns. Dos modos de habitar apresentados nas narrativas, alguns se destacaram, ou pela quantidade de filmes que afiguravam uma mesma tipologia de casas ou pela temática explorada em suas narrativas inserida em problemáticas vivenciadas na sociedade contemporânea. Foram eles, as moradas fixas, os espaços de trânsito e as residências precárias. Assim, atendendo aos critérios destacados, selecionamos os seguintes filmes: o filme de nacionalidade argentina e espanhola Um conto chinês (2011) do diretor Sebastián Borensztein; o filme Encontros e desencontros (2003) da diretora americana Sofia Coppola; e o filme francês Louise Wimmer (2012) dirigido por Cyril Mennegun.

Ainda que o corpus principal desta análise se configure como uma delimitação, os três filmes analisados contribuem na verificação das hipóteses apontadas 
anteriormente. Mais do que uma preocupação com períodos de lançamento e nacionalidades, a seleção se apoiou sobre diferentes formas de habitar o espaço urbano: uma casa, um hotel e um carro. As questões apontadas por esta tese não se encerram nesse recorte, pois a filmografia organizada sustenta-se como análise complementar, transpassando as diversas reflexões realizadas ao longo do trabalho e evidenciando outros tantos modos de habitar na contemporaneidade.

A proposta agora é fundamentar, por meio da análise fílmica, as hipóteses e problemáticas evidenciadas em capítulos anteriores. Importa investigar a inserção de personagens em instâncias de mobilidade no espaço doméstico, questionando seu sentido enquanto território fixo e seguro; espaços de trânsito e outros lugares inusitados assumindo o papel de residência, edificando modos de habitar transitórios; a configuração de espacialidades dicotômicas como o exterior e o interior; a alteração de usos e apropriações costumeiras dos lugares por parte de protagonistas-cosmopolitas. É importante ressaltar que a análise visa primordialmente a obra, mas atentando para sua inserção na construção de mundos imaginários do cinema mundial contemporâneo. Sabemos que os filmes selecionados não esgotam as problemáticas apontadas neste trabalho, mas evidenciam um modelo narrativo do gênero cotidiano que dê conta das experiências dinâmicas da sociedade urbana.

Antes de iniciar a análise fílmica, interessa para fins desta pesquisa, refletir sobre um espaço que se evidencia no encontro entre filmes e pesquisador. O pesquisador aqui é também espectador, e percorrer um filme se assemelha ao processo de elaboração deste trabalho. Mais do que uma narrativa finalizada, um ponto de partida e outro de chegada, o que se buscou é um atravessar, um entrelaçar. O método é do entrelaçamento, como uma costura que alinhava um ponto de cá e outro de lá, e na amarração vai juntando partes, demarcando limites. A análise fílmica junta o conceito e a imagem, o que vem de fora e o que vem de dentro, um pouco do filme e um pouco da imaginação e interpretação do "espectador-pesquisador".

Apoderamo-nos das palavras de Gilles Deleuze e Félix Guattari quando discorrem sobre rizoma apenas para dizer que cinema é movimento, mas não imagens que se movem em uma tela, e sim um tecido de matérias visuais e sonoras que se constitui no encontro, em um estado de confluência. O rizoma não tem ponto de partida nem ponto de chegada; é sempre intervalo entre uma coisa e outra; "tem como tecido a conjunção 'e... e... e" ", (1995, p. 36); não exclui um nem recusa o outro, congrega-os. 
Em regime rizomático, ao contrário, qualquer ponto pode ligar-se a qualquer outro, qualquer elemento pode afetar ou incidir em qualquer outro, sem ordem ou valor prévios, sem coordenação centralizada e fixa, num mapa aberto, - conectável em todas as suas dimensões, desmontável, reversível, suscetível de receber modificações constantemente (ibidem, p. 22).

De um lado o filme, do outro o "espectador-pesquisador", e na confluência a análise fílmica, o confronto entre ambos. Ainda que as análises sejam subordinadas aos filmes que as fundamentam, um filme não produz sentido por si só, e certamente remete a diferentes interpretações. Jacques Aumont e Michel Marie argumentam que a interpretação é “o 'motor' imaginativo e inventivo da análise; e que a análise bem sucedida será a que consegue utilizar essa faculdade interpretativa, mas que a mantém num quadro estritamente verificável quanto possível” (2009, p.15). O corpus de análise apreende o objeto no vão do "e... e... e". O vão é um espaço desocupado, aberto, concebe a apropriação imaginativa, o habitar individualizado. Tomando a narrativa como percurso de espaço, reconhece-se o método rizomático para investigar sentidos e subjetividades alicerçadas em uma imaginação criadora própria de cada filme e em uma dinâmica de leitura solitária. Contudo, o pesquisador não está sozinho, encontra em suas subjetividades e nas de seus autores uma forma de colocar em pé as casas feitas de imagens e sons.

Articular práticas de espaço, pormenores arquitetônicos e objetos cenográficos com temas e circunstâncias exploradas em um filme cria um mundo ficcional pleno de coerência e subtendidos, mas também alcança o pesquisador na elaboração de uma outra narrativa, aquela construída pela própria análise do objeto em uma interpretação induzida pelas materialidades fílmicas. Em sua descrição, a análise percorre os espaços fílmicos seguindo uma outra ordem que não a apresentada pela montagem do filme, instituindo percursos, alterando passagens, juntando e separando. Essa nova narrativa delimita incessantemente, e se apropria também. 


\subsection{Um conto chinês de Sebastián Borensztein}

Filme: UM CONTO CHINÊS

Título original: El chino

Diretor: Sebastián Borensztein

Atores: Ricardo Darín, Ignacio Huang, Muriel Santa Ana

Nacionalidade: Argentino, Espanhol

Ano de lançamento: 2012

Sinopse do filme: Jun, um chinês que perde sua noiva em um incidente com uma vaca que cai do céu, migra para a Argentina a procura de seu único parente vivo. Perdido na cidade, Jun se depara com Roberto, um argentino mal humorado e solitário, que mesmo a contragosto, leva o chinês para sua casa. Jun conhece também Mari, uma moça do interior apaixonada por Roberto. Durante a convivência, Jun e Roberto, mesmo sem falar a mesma língua, acabam por se comunicar e se ajudar.

\subsubsection{A casa de Roberto e Jun}

O filme se inicia com uma paisagem bucólica: um pequeno barco navega lentamente sobre um lago entre montanhas. Em seu interior, um casal apaixonado está prestes a ficar noivo. O letreiro abaixo da tela deixa claro sua localização: Fucheng, China. Um acontecimento trágico e ao mesmo tempo absurdo encerra, a princípio, esta possível história: uma vaca cai do céu bem no meio do barco. A narrativa é, então, retomada em outra localização: Buenos Aires, Argentina. Um recurso de linguagem enfatiza sua posição do outro lado da Terra: na imagem, uma casa aparece de cabeça para baixo retornando à sua posição normal após um giro na imagem de $360^{\circ}$ graus. História reposicionada e retomada em outro canto do mundo.

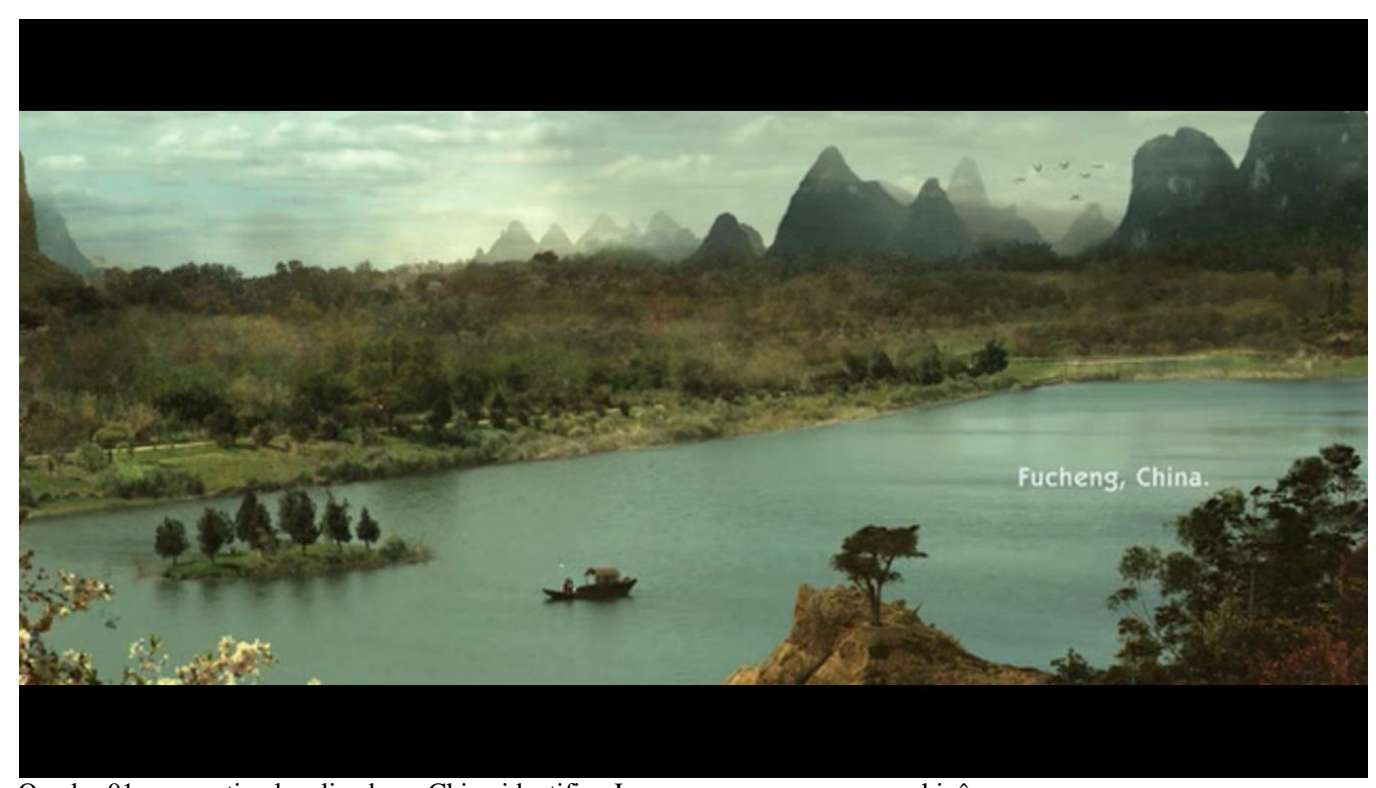

Quadro 01: a narrativa localizada na China identifica Jun como um personagem chinês. 


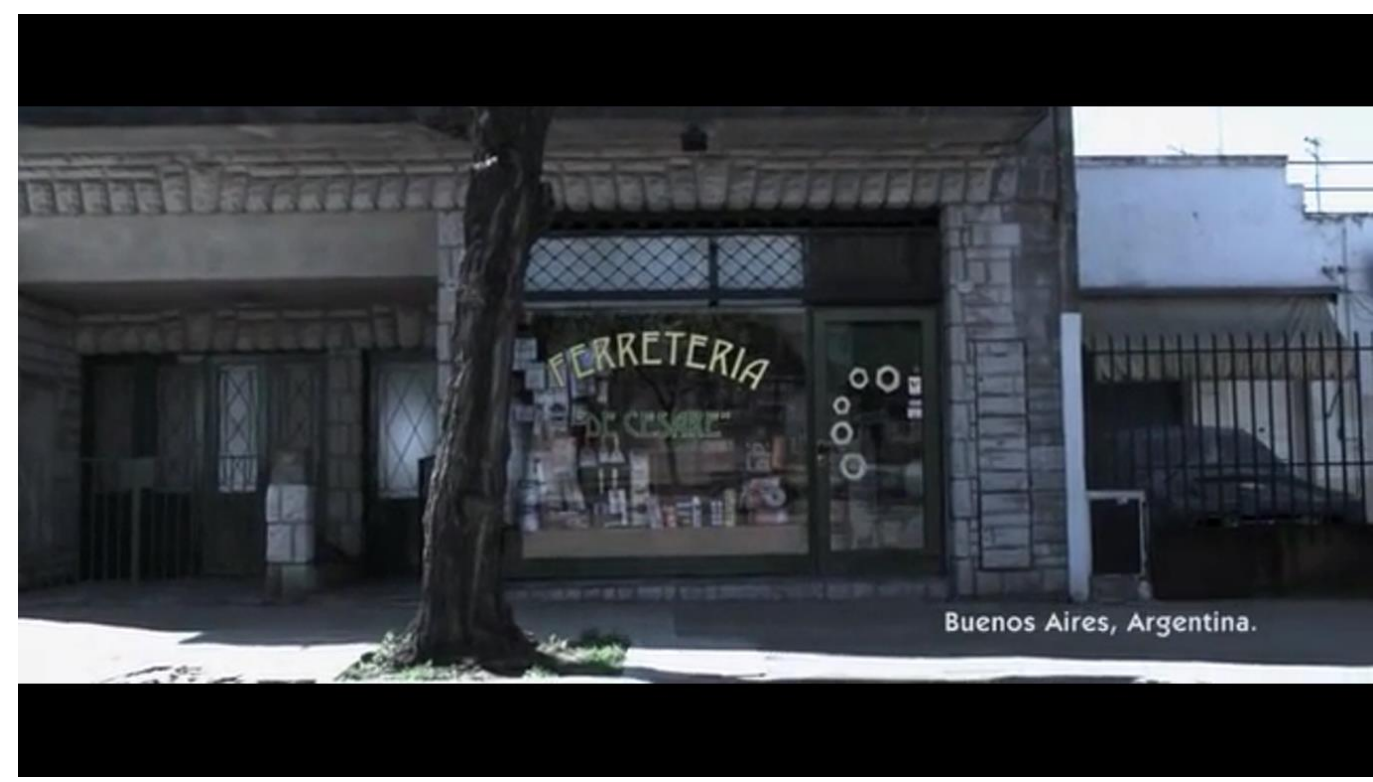

Quadro 02: a narrativa localizada em Buenos Aires identifica Roberto como um personagem argentino.

Aqui, para narrar é preciso primeiramente fazer referências à localização. Posicionar o lugar do acontecimento narrado abre uma base de apoio para a existência de personagens da ficção, instituindo o caráter do lugar em sua função de orientação, isto é, esclarecendo o local onde ele se encontra, e ao mesmo tempo, conferindo sua identificação. A cena inicial de Um conto chinês assegura certas particularidades dos personagens: Jun é chinês e Roberto é argentino. Entretanto, suas nacionalidades não servem apenas para justificar características físicas ou psicológicas, mas instauram uma polaridade entre dois mundos diversos.

A China é a localidade antípoda da Argentina. Dois pontos antipodais são opostos na esfera terrestre. O termo vem do grego e significa "pés opostos". Jun é antípoda de Roberto. Jun é chinês e se perde na Argentina, seus pés são errantes, não sabem muito para onde o levam. Roberto é argentino, dá passos certeiros da hora que acorda até a hora de dormir; anda pouco, alguns passos da casa para o trabalho, outros do trabalho para casa. Seu antípoda deu passos longos partindo da China e chegando à Argentina; parece perdido, mas tem ponto de chegada. Roberto tem endereço fixo, porém caminha desorientado. Jun é impulsionado pelo passado a viver o presente, Roberto diante do presente se estabelece no passado. É a partir do outro, que cada um define características e espacialidades.

O diretor Sebastián Borensztein explora temas como fronteira, migração e estrangeiridade na diegese fílmica. Sua narrativa fala de intercâmbio, de pessoas estrangeiras que se comunicam (ou não), e nos coloca sob a experiência do diferente. Ao cruzar o globo terrestre para se instalar na Argentina, o personagem Jun se pontua como 
um imigrante e expõe uma negociação entre diferentes nacionalidades. $\mathrm{O}$ caráter multicultural do filme se expressa, a princípio, nas duas línguas faladas: a língua espanhola e a chinesa. Os personagens falam línguas diferentes e enquanto usam as palavras para se comunicar pouco se compreendem. A narrativa busca questionar a força da linguagem no mero âmbito das palavras como forma de comunicação. Ao se encontrarem pela primeira vez, Jun fala sem parar e Roberto diz: "não entendo uma palavra". Então, Jun lhe mostra uma tatuagem no braço: Catáran 2737, localidade imediatamente identificada pelo argentino. Como estrangeiro, a linguagem no corpo tem mais serventia. Um endereço exato torna possível a chegada, dá rumo às ações e orienta o percurso da história.

Roberto e Jun são um o inverso do outro. A temática da migração posiciona espacialidades entre personagens. O crítico cultural Homi Bhabha, em seu livro O local da cultura, reflete sobre movimentos migratórios e a comunicação entre diferentes citando a obra de arte Sites of Genealogy ${ }^{70}$ da afro-americana Renee Green. A artista se serviu da imagem do sótão, da caldeira e do poço de uma escada na arquitetura como metáfora na indagação de diferenças construídas entre o negro e o branco.

O poço da escada como espaço liminar, situado no meio das designações de identidade, transforma-se no processo de interação simbólica, o tecido de ligação que constrói a diferença entre o superior e inferior, negro e branco. $\mathrm{O}$ ir e vir do poço da escada, o movimento temporal e a passagem que ele propicia evita que as identidades, a cada extremidade dele, se estabeleçam em polaridades primordiais (BHABHA, 1998, p.22).

A imagem da escada como espaço-ligação se dá no movimento entre um degrau e outro que leva, ora para cima, ora para baixo. Aquele que sobe, desce, e vice-versa. É o trânsito no vão da escada que impede a polaridade branco versus preto. Renee Green oferece um novo ponto de observação para um espaço comum e banal. Cada lugar tem sua especificidade, mas isolado de seu conjunto, se vincula a uma mudança em sua percepção e sensibilidade.

De modo semelhante, para Michel de Certeau, a noção de fronteira se relaciona à imagem da ponte que separa e igualmente comunica, é sempre passagem entre uma extremidade e outra. "No relato, a fronteira funciona como um terceiro. Ela é um 'entre dois' - 'um espaço entre dois', [...] é como um vácuo, símbolo narrativo de intercâmbios

\footnotetext{
${ }^{70}$ Obra de Renee Green Sites of Genealogy (Out of Site, The Institute of Contemporary Art, Long Island, Nova Iorque).
} 
e encontros" (2009, p.195). A casa, em Um conto chinês, é um espaço-ligação, faz a ponte, separa e vincula, demarca ao mesmo tempo em que une. Em ambos os autores, escada e ponte aparecem como fronteira, espaço articulado, sujeito a deslocamento, lugar intervalar onde os conflitos acontecem, e onde a negociação é também possível.

A inserção do estrangeiro Jun no espaço doméstico de Roberto questiona sua noção enquanto território estável, apreendendo-a enquanto lugar fronteiriço entre protagonista e antagonista. O lugar tomado como referência, uma casa, assume aqui um papel de coadjuvante. Como espaço-ligação, a casa da ficção se disponibiliza enquanto possibilidade narrativa na articulação entre mundo íntimo e mundo compartilhado, entre espaço de fixidez e mobilidade espacial. Há aqui um esforço de rompimento de barreiras sociais, culturais, de nacionalidades, mas também do caráter do lugar em sentidos e funcionalidades aparentemente manifestas: a casa não é mais um lugar para morar, se transmuta em espaço de trânsito, em ponto de intersecção entre desiguais.

\subsubsection{O dentro e o fora}

Em filmes de ficção, a composição dos lugares enquanto edifícios (casa, escola, hospital, loja, etc.) se faz, também, a partir de uma contraposição entre exterior e interior. Os roteiros de cinema apresentam sempre a identificação dos ambientes (ou cenários) acompanhadas pela indicação "exterior" ou "interior". Essa dualidade leva ao entendimento fragmentário do habitar. Gaston Bachelard (2003, p.219) separa o dentro e o fora a partir dos espaços da casa: "o interior e o exterior não recebem do mesmo modo os qualificativos, esses qualificativos que são a medida da nossa adesão às coisas. Não se podem viver da mesma maneira os qualificativos ligados ao interior e ao exterior". O caráter dos espaços internos se define, a princípio, de modo diverso ao dos espaços externos. Se o primeiro é resguardado, o segundo seria desprotegido; se um é reservado, o segundo é acessível; o dentro constitui o espaço restrito enquanto o fora se caracteriza ilimitado.

A noção da casa como um local abrigado pressupõe uma contraposição entre o mundo de dentro e o mundo exterior. Do lado de dentro, o homem está abrigado, mas do lado de fora se encontra vulnerável, em posição instável e sujeito às mobilidades da dinâmica urbana. Em concretudes, são as paredes, as portas e janelas que dão conta da dualidade entre o interior e o exterior, entre uma vida privada e outra pública. As paredes 
se erguem como barreiras, enquanto a abertura de janelas e portas se reconhecem em permeabilidades.

Pensar o dentro e o fora em espacialidades fílmicas beira uma noção de fronteira, que a princípio parece separar duas coisas. Um muro separa o dentro e o fora. O dentro parece negar o fora, enquanto o estar fora excluiria o permanecer dentro. A princípio, um se opõe a existência do outro. Entretanto, ao enquadrarmos a vida cotidiana em imagens cinematográficas, afirmamos ao contradizer. A escala humana, o mundo íntimo e compartilhado do personagem se constitui na confrontação com a escala urbana, a esfera da cidade e da sociedade a qual ele aparece inserido. $O$ privado se ergue em referência ao público, a existência de um é a permanência do outro.

Gaston Bachelard acredita que "a dialética do dentro e do fora se multiplica e se diversifica em inúmeras nuances" (ibidem, p. 219). O filósofo vasculha o interior do ser para alcançar experiências vividas no exterior. Em seu entendimento, ao sair fora de si, o ser toma consistência de seu âmago. Nos filmes selecionados para esta tese, a dinâmica de espacialidades entre interior e exterior cria percursos de espaço, apreendendo o dentro e o fora com toda sua variabilidade de sentidos. Mais do que uma dualidade entre dois lugares distintos, aspira-se encontrar espaços de interseção que se compõem com um pouco de fora e um pouco de dentro, ou um fora enclausurado e um dentro disposto em fendas e aberturas.

O jogo entre o dentro e o fora no filme Um conto chinês se encontra em diferentes instâncias narrativas: na constituição da habitação onde mora o personagem Roberto, nas características de Jun, que é estrangeiro e passa a habitar o espaço de dentro, e nas imagens da porta como fragmento arquitetônico que, quando fechada, cumpre um papel de confinamento, e quando aberta induz personagens "porta à fora".

$\mathrm{Na}$ aparência da casa, a composição da fachada posiciona a dialética exteriorinterior. A fachada é a parte exposta da morada, a superfície onde se acomodam os olhares, a porção do habitar ostentada pelo morador, ela está no limiar de sua privacidade. Por trás de seu aspecto frontal, o morador se oculta, mas na casa de Roberto a fachada é a confissão do modo como leva a vida cotidiana. Sua residência é modesta e dividida em duas: do lado esquerdo, a fachada apresenta o domicílio com porta e pequenas janelas com grades de segurança; do lado direito, deixa visível seu estabelecimento comercial em painel envidraçado e um letreiro que indica "loja de ferragens".

O princípio da dualidade casa-trabalho exposto na aparência da morada instaura mais do que visibilidades, um modo de habitar próprio de Roberto: seu cotidiano se divide 
entre alguns afazeres domésticos e seu ofício no comércio. Suas ações se organizam, ora em casa entretido com tarefas triviais, ora na loja de ferragens atendendo clientes e organizando pequenos objetos. Da mesma maneira, o interior de sua casa se estrutura em um tênue limiar entre o espaço doméstico e o local de trabalho. Estão lado a lado, são ambientes contíguos. Roberto trafega entre um e outro sem barreiras, uma simples soleira separa o mundo doméstico do mundo do trabalho. Na residência de Roberto, entre habitar e trabalhar, a porta não abre nem fecha, fica sempre entreaberta. Não há fronteira demarcada entre um espaço e outro.

Ainda na fachada, o dentro e o fora se revelam em transparências e nos questionam sobre visibilidades e delimitações. Em sequência inicial do filme, um movimento de câmera de aproximação contínua encaminha o espectador do espaço da rua para dentro da loja de Roberto. Na passagem entre exterior e interior, não há barreiras nem fronteiras. A câmera atravessa o vidro e une o fora e o dentro. A fachada da loja envidraçada não divide, apenas exibe o interior, ao mesmo tempo em que evidencia seu exterior. Sua transparência deixa visível ambos os lados e não propõe delimitações. Localizada do lado de fora da loja, a personagem Mari observa Roberto ao telefone. O vidro deixa claro suas particularidades: um homem resmungão e mal humorado.

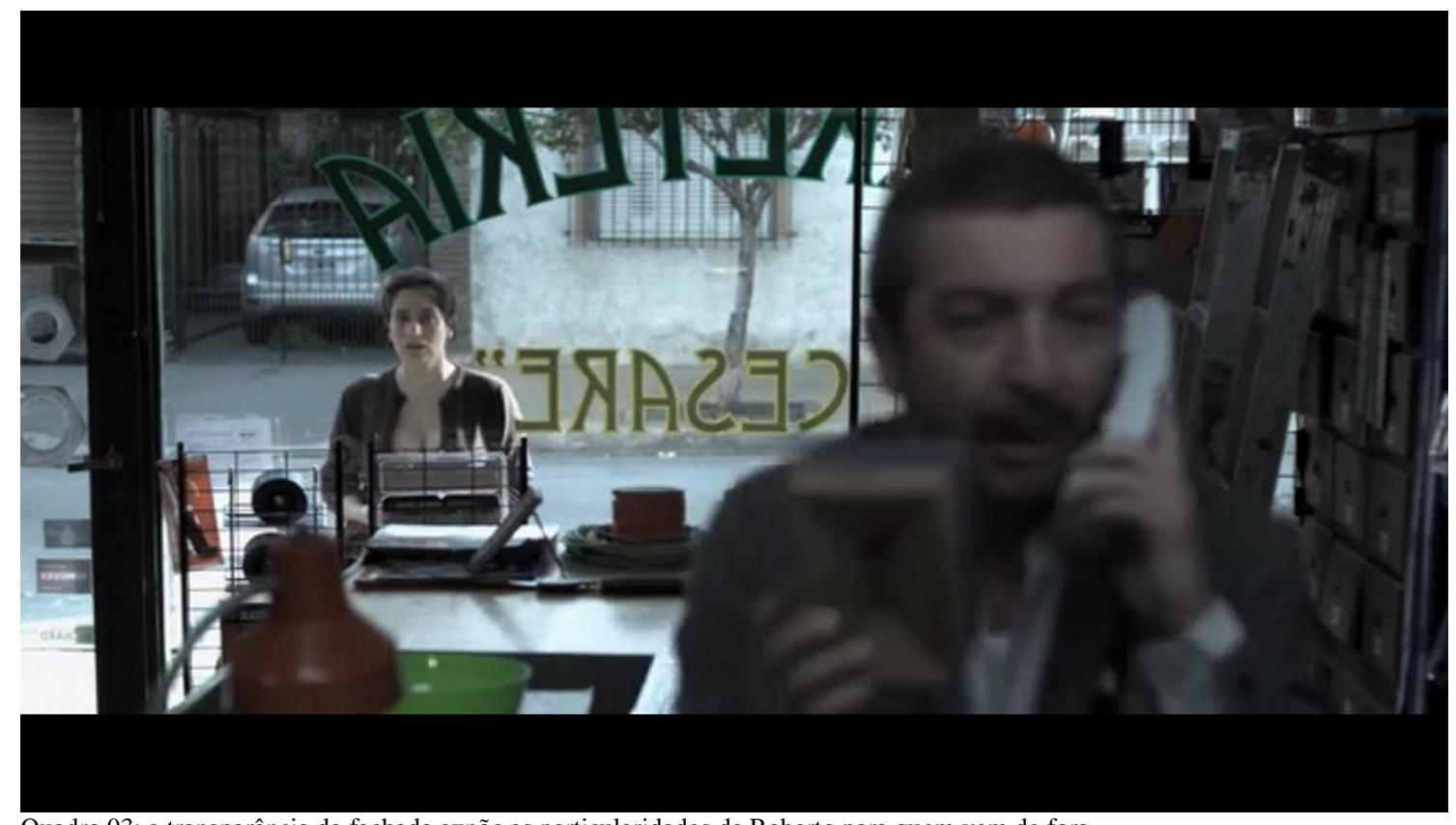

Quadro 03: a transparência da fachada expõe as particularidades de Roberto para quem vem de fora

A casa se localiza na cidade de Buenos Aires, mas não há qualquer outro indicativo sobre sua localidade. Ainda que não haja muros ao seu redor, o modo como a residência é explorada em suas imagens a desvincula de um possível entorno, reproduzindo uma atmosfera de isolamento para sua narrativa. Se há prédios e vizinhos 
ao seu redor, isso não é visível. Se há avenidas, tráfegos ou movimentos urbanos nas cercanias, isto não é audível. No filme, não há contiguidades com vizinhanças, as janelas permanecem fechadas para o exterior. A residência é representada como silenciosa e solitária, igualmente a seu dono. Roberto leva uma vida alienada, evitando qualquer proximidade com o outro. O personagem habita só e permanece encerrado em uma solidão feita de coleções e de ritos. As espacialidades fílmicas são construídas com o intuito de enfatizar um isolamento do mundo ao redor, instaurando personagens e espaço narrativo em uma dimensão privada. A vida social de Roberto é quase inexistente. $\mathrm{O}$ moço tem uma posição fixa, quase não se desloca. Se alguém quer ver Roberto, sabe muito bem onde encontrá-lo.

Na morada de Roberto, a fachada negocia a rua e o doméstico; o corredor une a cozinha com o quarto; a porta é a ponte entre dentro e fora, precisa ser atravessada. A casa se constrói na dinâmica de trânsitos, delimitações e intercâmbios; é por si só fronteira. A mise-en-scène articula personagens, espaços e objetos no encontro (ou desencontro) com o outro. Em seu interior, é espaçosa e modesta: dois quartos, sala, banheiro, pátio, e uma cozinha pequena. Ao fundo dessa, uma escada, onde ninguém desce nem sobe. Sem imagem para mostrar a ação praticada - neste caso, subir ou descer -, o fragmento arquitetônico é pura aparência, fachada. Quarto, corredor, banheiro, todos os cômodos no mesmo piso, é então uma casa horizontal. A horizontalidade põe todos na mesma altura, nos iguala, consente a identificação e a aproximação com o outro.

No percurso de sua narrativa, o cineasta Sebastián Borensztein "cerca" a casa em imagens diversas e nos conduz ao espaço doméstico. Planos fixos com poucos movimentos, planos mais fechados, de conjunto e planos médios convergem o olhar do espectador para a estabilidade e o espaço íntimo. O silêncio no interior dos ambientes da casa reforça a concentração no espaço de dentro. Para Christian Norberg-Schulz "a propriedade básica dos lugares criados pelo homem é a concentração e o cercamento" (2008, p. 448). Ao analisar os espaços construídos pelo homem, o arquiteto aproxima o conceito de cercamento à noção de fronteira. Cercar se relaciona ao ato de demarcar. Ao cercar, demarcamos fronteiras entre exterioridades e interioridades. Com sua câmera, Borensztein confronta personagens e espacialidades apenas para dizer que a fronteira é também um ponto de encontro.

Quando o personagem Jun chega à casa de Roberto, a questão da alteridade deixa o mundo do trabalho, na relação com seus clientes ou passantes da loja, e passa para o interior do espaço doméstico, no encontro com o estrangeiro. A narrativa parece ser 
contada do ponto de vista de Roberto - estamos em sua casa e a passagem de seu antípoda é apenas provisória - mas é a passagem de Jun que posiciona as estratégias narrativas e mobiliza um entendimento de um modo de habitar transitório.

A pesquisadora Andréa França investiga em seu livro Terras e fronteiras: no cinema político contemporâneo, o espaço estrangeiro a partir do fora. Espacialidades fílmicas como o fora-de-campo e o desenquadramento na imagem cinematográfica são pensados a partir do tema da alteridade.

\begin{abstract}
Trata-se de um modo de desenquadrar, próprio à potência do pensamento e da arte, cuja importância é decisiva para introduzir o Estrangeiro numa imagem que nunca é perfeitamente fechada. Erigir uma relação da imagem com o extracampo absoluto é poder sustentar uma relação com o Estrangeiro que jamais se atualiza na imagem, pois pertence a uma região estranha à figuração, sem que no entanto seja completamente invisível, pelo contrário, ele insiste e persiste na imagem (2003, p.194).
\end{abstract}

Jun é estrangeiro, vem de fora, mas em Um conto chinês a imagem do estrangeiro é construída a partir do dentro. O ponto de observação proposto pelo filme posiciona o espectador no interior da casa; da cidade, pouco se vê: algumas poucas cenas para justificar a procura do tio de Jun e outras para reforçar o sentido de um personagem estrangeiro perdido na cidade de Buenos Aires. Fazendo um paralelo com a filosofia de Gaston Bachelard, o imaginário da casa se traduz como espaço fechado, abrigado. O espaço doméstico é vivido pelo morador em suas lembranças, traçando a fenomenologia do habitar no encontro com seu primeiro universo. "A vida começa bem, começa fechada, protegida, agasalhada no regaço da casa" (2003, p.26).

O espaço interno da casa de Roberto é tomado pelas lembranças da vida familiar (as coleções da mãe, o quarto dos pais falecidos, as fotos de família), mas, sobretudo, aparece confrontado pela presença de um desconhecido. Ao colocar um estranho dentro do espaço íntimo, inverte-se a fronteira entre esfera privada e pública, entre exterior e interior e passa-se a observar o fora a partir do dentro. Essa mudança inverte também uma noção de casa como espaço rígido e sugere um modo de habitar transitório. Aqui, a narrativa formula questionamentos sobre a maneira como o espaço doméstico pode ser colocado em cena a partir de diferentes pontos de vista; e mais, pode ser rompido e reestruturado em novas espacialidades.

De todos os fragmentos arquitetônicos para expressar os valores da mobilidade entre o dentro e o fora, a porta é provavelmente o que mais se mostra perceptível. As 
imagens de portas são inúmeras: pela porta do carro, Roberto conduz o estranho à rua; na embaixada chinesa, o segurança coloca Roberto porta à fora; ao abrir a porta do banheiro, Roberto se depara com Jun em momento privado; porém, é a porta do quarto de hóspede que oferece à imaginação a expressão da espacialidade embaralhando o protegido ao desconhecido.

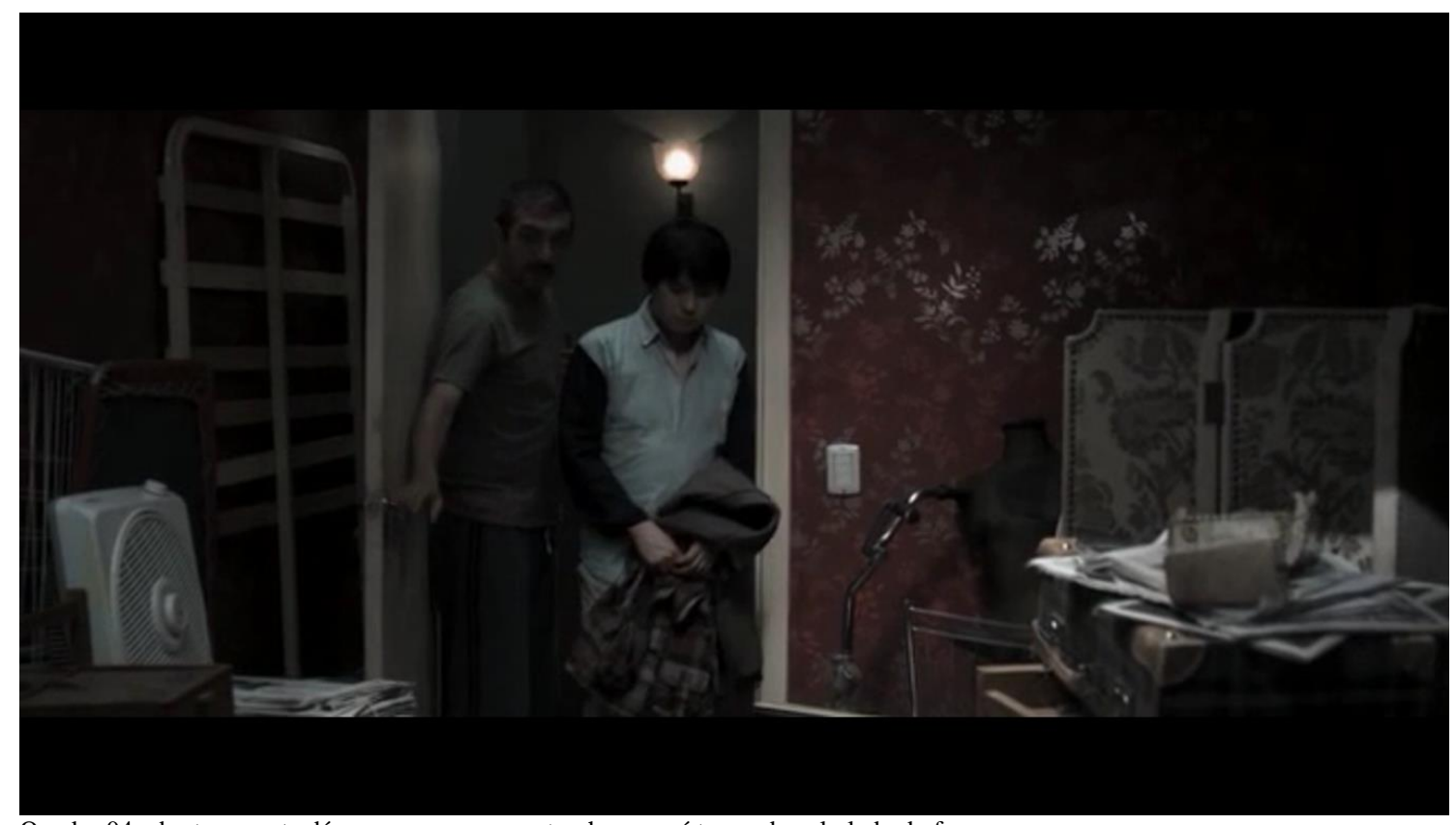

Quadro 04: aberta, a porta dá passagem para o estranho, mas é trancada pelo lado de fora.

Ao trancar a porta do quarto, Roberto deixa o desconhecido aprisionado do lado de dentro, enfatizando a presença de um estranho no espaço seguro da casa. Mostrada em plano detalhe, a ação de girar a chave coloca o espaço privado no limiar com uma possível invasão. Essa miudeza impede o transitar, cruzar a ponte ou a escada, e ilude uma inevitável intrusão. Fechar a porta da casa com chave nos manteria resguardados no espaço de dentro, dos perigos do exterior. Entretanto, na residência de Roberto, o perigo se encontra no interior. O estranho é trancado do lado de dentro, no quarto, território privado, ambiente de maior intimidade no espaço doméstico. Isto é, com certeza, um paradoxo.

\subsubsection{As práticas de espaço}

As práticas cotidianas analisadas por Michel de Certeau reconhecem o movimento como elemento central para a transformação do lugar. Praticar um espaço é percorrê-lo e apropriá-lo em operações de demarcação. Quem caminha não apenas observa a paisagem, 
reforça as marcas do trajeto ou fixa seus próprios traços. Em parceria com Pierre Mayol e Luce Giard (1996), Certeau se interroga sobre as práticas urbanas a partir do ato de morar e cozinhar. O primeiro autor (ibidem, p.37-185) investiga o bairro como espaço intervalar entre a intimidade do domicílio e o reconhecimento no espaço público, descrevendo as atividades de seus habitantes; enquanto o segundo (ibidem, p.211-332) explora as tarefas diárias no universo feminino e no ato de cozinhar. Ao investigar os modos de apropriação das pessoas comuns dentro do bairro e da cozinha, os autores elaboram um entendimento sobre as práticas cotidianas no sentido fenomenológico e valorizam a cultura ordinária como um discurso do habitar.

Comer e dormir são práticas cotidianas realizadas no espaço doméstico que conduzem os modos de habitar na contemporaneidade. Na experiência vivida, observamse mudanças na apropriação dos espaços de se alimentar e de se repousar e no modo de se realizar cada prática. Os atos cotidianos, nas narrativas do cinema mundial, são ações praticadas por protagonistas-cosmopolitas de diferentes formas e lugares segundo o qual o habitar toma forma. São as ações e apropriações dos espaços pelos personagens que instituem modos de habitar ficcionais.

Em Um conto chinês, confrontar o espaço íntimo e a presença de um estranho desestabiliza o alicerce que mantém a casa “em pé”. As práticas diárias do personagem Roberto são a pura expressão da ordem: o dono da casa circula em um mundo comodamente habitável e bem organizado. Em seu mundo metódico, cada coisa se encontra em um lugar preciso: as pequenas coleções na cristaleira, as ferramentas em suas respectivas caixas, seu dia-a-dia estruturado entre espaço doméstico e trabalho e, hora certa para dormir. A noção de ordem se expressa em diferentes materialidades do espaço doméstico: na aparência da casa (na simetria da habitação geminada), no jogo espacial instaurado entre os personagens (em campo e contracampo), na organização dos objetos (na cristaleira e nas gavetas da loja), no modo de habitar de Roberto. Há um esforço de construção das práticas cotidianas a partir da ordem e da desordem.

Jun é um estrangeiro e como tal, não está aqui nem lá, seu pertencimento é transitório: ora é chinês, ora habita na Argentina. Ele abandonou sua residência e se abriga provisoriamente na casa do outro. Por certo tempo, realiza suas práticas cotidianas em território alheio. Está em trânsito, na fronteira, atravessando... O significado da palavra “atravessar" nos remete ao ato de percorrer um espaço, mas é também andar atravessado, no meio de, entre. A permanência de um estranho no ambiente íntimo abre um espaço de negociação constante entre os habitantes. O proprietário intransigente não faz acordos, 
apenas expõe regras e prazos; enquanto o visitante, apenas as obedece. O nome Jun vem do japonês e quer dizer obediente. Para superar as diferenças, Jun não se sobrepõe a Roberto, alcança-o obedecendo-o e se deslocando conforme sua orientação. Os gestos de Roberto guiam as práticas do estrangeiro como uma marionete.

Roberto fixa na porta da geladeira o limite máximo da permanência de Jun em sua casa: sete dias, que seguem contando como um cronômetro, estruturando a cronologia cotidiana da narrativa. O dono da casa demarca seu território - e o de seu hóspede - a partir de suas ações. A casa é dele, é ele quem delimita fronteiras nesse espaço: ele demarca os espaços de uso do outro, limita seu tempo de permanência, bem como define as práticas diárias realizadas pelo estranho no espaço doméstico. Na casa aparentemente limpa e ordenada, há espaços abandonados e desabitados. A chegada do estranho revitaliza lugares esquecidos. Aos poucos, Roberto se serve da presença de Jun para colocar ordem em sua morada. $\mathrm{O}$ anfitrião justifica a permanência de seu visitante na casa, da mesma forma que faz com as ferramentas de sua loja: cada qual com sua funcionalidade.

Um dos cômodos bagunçados da residência é o quarto de hóspede relacionado à prática de receber visitas, ato desprezado pelo morador. O quarto é o espaço apropriado para dormir, o canto do repouso, do encontro consigo mesmo. O ato de dormir confronta o anfitrião e o visitante. Enquanto para o primeiro, o quarto se apresenta como espaço do repouso, para Jun, o quarto é um espaço provisório; o anfitrião dorme com horário fixo, enquanto seu visitante tem pesadelo; sob a cama do primeiro, uma colcha feita à mão, sob a outra, uma mala velha, uma cesta de lãs e alguns outros entulhos; um quarto é limpo e organizado, o outro é somente desordem.

Visto como um obstáculo para uma vida regrada, o estrangeiro precisa ser expurgado. De um lado, Jun se posiciona como aquele que instala a desordem na vida cotidiana, do outro se define como o que expurga as sujeiras. Sob o controle de Roberto, Jun se desfaz dos objetos entulhados da casa. A noção de "pureza" de Zygmunt Bauman aparece nas práticas cotidianas dos personagens. "Varrer o assoalho e estigmatizar os inimigos ou expulsar os estranhos parecem provir do mesmo motivo de preservação da ordem" (1998, p. 16). A primeira ação de Roberto ao receber Jun em sua casa é mandálo tomar um banho. As sujeiras devem ficar do lado de fora. Roberto quer expulsar Jun, como não consegue, encontra uma utilidade para o estrangeiro que passa a limpar a casa, retirando inutilidades. 
Ao tentar colocar em ordem os entulhos do quarto, Jun destrói involuntariamente a coleção de objetos feita em homenagem à mãe de Roberto. $\mathrm{O}$ estrangeiro quebra o vidro da cristaleira onde estão expostas as miudezas. O desmantelamento leva à sua expulsão da casa. Os objetos destruídos e fora do lugar dão um ponto final no modo como Roberto se relacionava com coisas e pessoas, e uma nova ordem pode se estabelecer. Para Bauman (ibidem), ordenar deixa de ser uma forma de manter as coisas intactas para se alternar em ato de desmantelamento. Esse modo de colocar em ordem remete às práticas realizadas em outros espaços domésticos, uma constante negociação entre o personagem de dentro e aquele que veio de fora. E é, sobretudo, na cozinha que os encontros e as negociações acontecem.

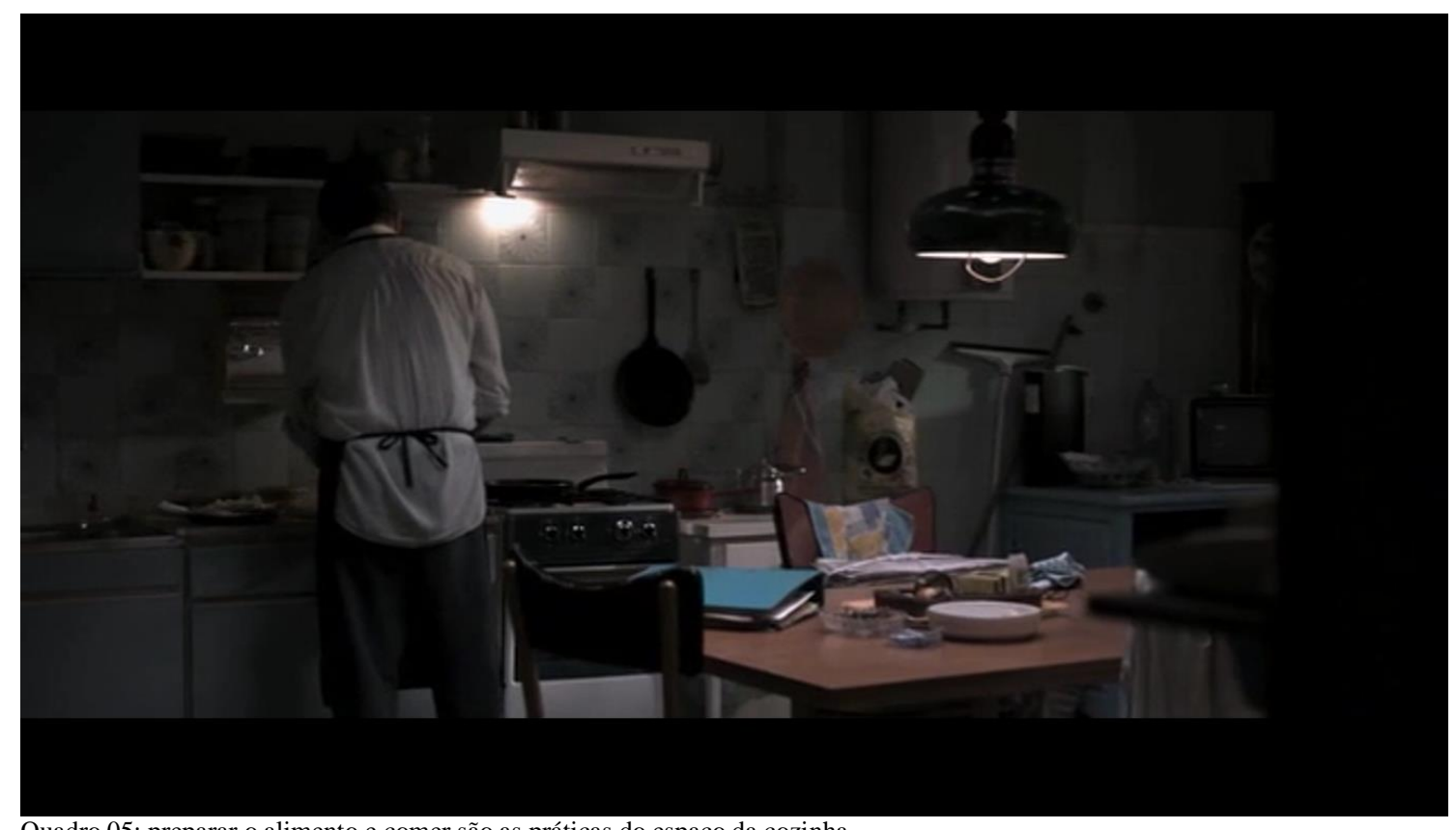

Quadro 05: preparar o alimento e comer são as práticas do espaço da cozinha.

A cozinha exibe a simplicidade do morador: as cores são neutras, a geladeira velha, alguns utensílios e um pequeno calendário mal fixado na parede, poucos pratos, um armário, prateleiras, pilhas de jornais, o telefone... e no centro uma mesa. Aqui se come na cozinha, não há sala de jantar para refeições em família e entre amigos. Sua localização se dá entre o quarto e a área de lazer, uma ponte entre a intimidade e uma possível convivialidade. Uma cozinha se presta à convivência e à prática cotidiana de se alimentar. Ao comer, Jun imita o modo de se alimentar do anfitrião, na tentativa de se aproximar do diferente. Imitando gestos, o estrangeiro tenta a igualdade na prática alheia.

No ambiente da cozinha, o jogo das espacialidades é um modo de perceber este espaço. Roberto exterioriza afeto através da comida. Na chegada de Jun, com a intenção 
de cuidar, Roberto serve vísceras de vaca argentina para seu convidado; em sua possível partida, de forma convivial, oferece doce de leite argentino. $\mathrm{O}$ ato de comer insere os personagens em uma ação diária e repetitiva. As comidas servidas em Um conto chinês são variadas: filé a cavalo, vaca argentina, ossobuco, comida chinesa, doce de leite. O alimento é sinônimo de prazer, são "iguarias" como diz o anfitrião. Aqui "se festeja com comida", Mari reconhece. Roberto tem orgulho de sua comida. A prática de preparar o alimento e de servi-lo faz a transição de Roberto de um homem frio e distante para alguém mais humano.

Na cozinha tem a comida, mas também a mesa. Esse móvel tem múltipla função: come-se, lê-se jornal, negocia-se em torno dela. A mesa é o móvel do compartilhamento: preparamos as refeições, conversamos e comemos juntos. A mesa acolhe a todos, até mesmo os estranhos. À mesa, temos a mesma grandeza: somos todos da mesma altura. No jantar na casa do irmão de Mari, Jun é convidado e se senta no meio, entre todos. Não existe adversários ali, a imagem é de reunião. Há mobilidade em torno da mesa: as imagens enquadram os personagens aleatoriamente, ora um, ora dois, ora todos. Conversam amenidades e todos têm direito à fala. A mesa separa e une ao mesmo tempo, é fronteira na certa.

Ao exibir as sequências de Roberto e Jun em torno da mesa da cozinha, o diretor Sebastián Borensztein realiza um trabalho de confrontação entre os personagens a partir do uso do campo e contracampo: ele os coloca um defronte ao outro. A noção de fronteira se expõe em práticas e materialidades no encontro com o outro: une e divide. Na imitação, o diretor identifica um personagem ao outro e os assemelha. Na confrontação, filmados em planos diferentes, o diretor os sujeita a suas individualidades. São iguais e diferentes ao mesmo tempo.

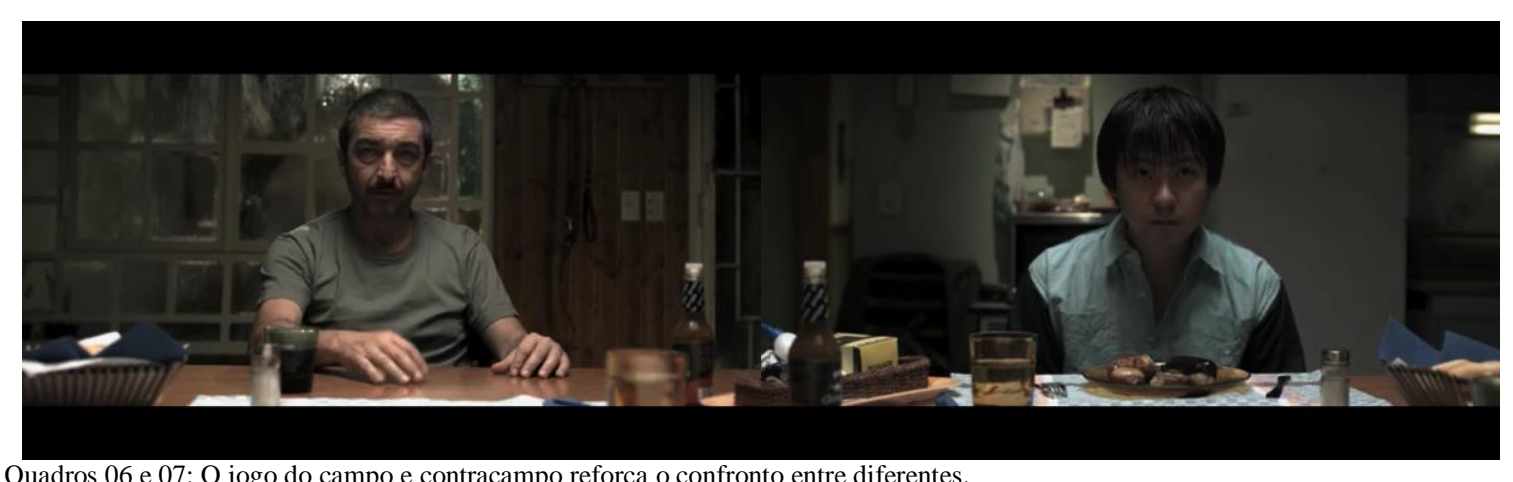

Quadros 06 e 07: O jogo do campo e contracampo reforça o confronto entre diferentes. 


\subsubsection{Os detalhes narrativos: pequenas coleções e ferramentas}

Nos filmes do gênero cotidiano, as práticas de espaço se revelam nas ações triviais dos personagens, mas também nos objetos ordinários do dia-a-dia. Se a cama se associa ao ato de dormir e a mesa leva à organização da prática de comer, a observação desses fragmentos evidencia diferentes formas de apropriação dos ambientes e um modo de habitar próprio de cada personagem. Os homens comuns são, agora, cosmopolitas e se deslocam o tempo todo, indaga-se, então, sobre os pequenos objetos como detalhes narrativos desses novos modos de habitar.

Para pensar o sentido de um objeto cenográfico em filmes de ficção, o personagem Roberto de Um conto chinês seria o modelo perfeito de sua expressão. Roberto é misantropo, ele não gosta de gente, só de coisas. Suas palavras e gestos exalam seu desapontamento alheio. Emprestado do grego (mis - anthropo), a palavra "misantropo" traz o significado daquele que odeia os homens, mais tarde atenuada passou a reconhecer aquela pessoa mal humorada e pouco sociável ${ }^{71}$. A misantropia de Roberto se relaciona ao seu isolamento e ao seu modo de habitar. Roberto não se entende com gente viva, mas fala com gente morta.

A casa de Roberto se instala em um modo de habitar conduzido pela lembrança e pelo passado: sua morada é uma casa natal, isto é, a residência de seus pais. Nesta dimensão, as práticas cotidianas, as espacialidades, os objetos nos levam a percorrer o espaço doméstico no encontro com um referencial, sejam os pais, a família ou o passado. Encerrado em um acontecimento infeliz do passado - a guerra, a morte do pai e a ausência da mãe ainda jovem -, Roberto busca na ritualização e na similitude uma forma de mantêlos vivos. Ele se esforça em manter as coisas como antes, conversa com sua mãe morta e copia as manias dos pais; a loja de ferramentas é uma de suas heranças. Mimetismo sobrepõe pais e filho, passado e presente.

Não há vida cotidiana sem imitação [...]; sem mimese, nem o trabalho nem o intercâmbio seriam possíveis. Como sempre, o problema reside em saber se somos capazes de produzir um campo de liberdade individual de movimentos no interior da mimese, ou, em caso extremo, de deixar de lado completamente os costumes miméticos e configurar novas atitudes (HELLER, 2000, p.36)

\footnotetext{
${ }^{71}$ Disponível em < http://historique. fracademic.com/12868 $>$. Acesso em 03 nov 2013.
} 
Roberto imita seus pais involuntariamente. A imitação se relaciona, conforme teorizado por Agnes Heller, à vida cotidiana. Estar presente na cotidianidade inclui a mimese como forma de continuidade de hábitos e costumes, mas também relaciona a mimese à alienação. "A vida cotidiana, de todas as esferas da realidade, é aquela que mais se presta à alienação" (ibidem, p.37). O cotidiano compreende a imitação e, do mesmo modo, a liberdade individual. Sem uma possível movimentação que conduz cada indivíduo a buscar sua própria trajetória, o cotidiano nos defronta com a imitação e se encerra na alienação. Roberto permanece estagnado em espacialidades ocupadas por pequenos objetos e rituais repetitivos.

Jean Baudrillard, em seu livro $O$ sistema dos objetos, se dedica aos objetos de coleção contrapondo seu valor funcional e simbólico. O primeiro se esgotaria na cotidianidade, enquanto o segundo corresponderia ao subjetivo, isto é, ao valor que um indivíduo pode conferir a um simples objeto. O autor destaca o objeto antigo como um reorganizador espacial e associa o ato de colecionar a questões pessoais.

[...] o objeto puro, desprovido de função ou abstraído de seu uso, cobra um status social estritamente subjetivo. Converte-se em objeto de coleção. Deixa de ser tapete, mesa, bússola ou bugiganga para converter-se em "objeto". Um "magnífico objeto" dirá o colecionador e não uma magnífica estatueta. Quando o objeto não está especificado por sua função, está qualificado pelo sujeito (1997, p.94).

Roberto é um colecionador involuntário. Sua mãe colecionava bibelôs, e agora é a sua vez. Ele se encontra inserido em uma espécie de moto-contínuo assimilado no espaço da casa. As pequenas coleções de objetos acabaram servindo para algo mais do que possíveis funcionalidades. Elas lhe proporcionam segurança e estabilidade. O espaço doméstico é também a casa dos pais, e aparece mapeado por objetos de coleção familiares. Estar envolto por esses objetos, por essas pequenas lembranças é permanecer abrigado pela presença de seu pai e de sua mãe. A composição espacial do espaço doméstico de Roberto insere o personagem em um modo de habitar que não lhe é próprio. Ele percorre o espaço presente estagnado no passado.

Agnes Heller entende que um homem se torna um adulto quando é "capaz de viver por si mesmo a sua cotidianidade" (ibidem, p.18). O amadurecimento se associa à manipulação das coisas, dos objetos cotidianos, bem como às relações sociais. Roberto se relaciona bem com objetos, mas tem dificuldade de se relacionar com pessoas. Afinal 
de contas, qual a serventia de pratos afixados em uma parede e uma coleção de cinzeiros em casa de não fumantes?

Para Baudrillard, o colecionador investe em objetos tudo o que poderia ter devotado em relações humanas. "Os objetos desempenham um papel regulador na vida cotidiana, neles desaparecem as neuroses, se reduzem tensões e energias" (ibidem, p.102). O colecionador de Um conto chinês tem dificuldade em interagir com gente, para ele é mais fácil se confrontar com objetos, sejam as ferramentas, sejam os bibelôs. Pequenos aviões, latinhas, miniaturas de garrafas de bebidas estão espalhadas pelo espaço doméstico. As coisas preenchem o vazio e amenizam suas neuroses. Entre suas coleções, Roberto se atém a uma em especial: recortes de notícias absurdas de jornal. Essa coleção diz muito sobre o modo de habitar de Roberto.

Roberto vive uma vida sem graça preso a um cotidiano banal. Como diz ele, " $a$ vida é um grande sem sentido, um absurdo". Seu hábito de colecionar notícias insensatas - a única coleção que ele começou por conta própria - contrapõe a banalidade de sua vida diária com uma possível realidade inusitada. A noção de limiar aparece aqui entre recortes que expõem tragédias alheias e a existência do insólito em sua cotidianidade. A maneira como essas histórias são mostradas no filme gera um relato à parte, onde Roberto se posiciona como narrador e ao mesmo tempo como protagonista. A narração em primeira pessoa insere sua figura nos acontecimentos relatados expondo seu ponto de vista e desvendando seu perfil psicológico. Enquanto narrador, Roberto posiciona conhecidos como personagens secundários e vivencia cenas hilariantes, aproximando os atos descritos ao seu cotidiano: ele finalmente se livra de seu chato cliente e pode viver uma tórrida paixão com a doce Mari. Esses contos trágicos são pequenos percursos de espaços onde a narrativa é sempre precedida de sua localização. Nas imagens, planos em plongée $e^{72}$ expõem a fragilidade humana diante de um possível destino, e talvez responda a questão do protagonista: “por que está metido nesta história com Jun?”.

Se as coleções e os pequenos objetos da casa traçam percursos de espaços, no local de trabalho, as pequenas miudezas são o caráter do modo de habitar do proprietário. Na loja de ferramentas, os pormenores estão por toda parte. Em pequenas caixas atrás do balcão ou em gavetas de tamanhos diferentes. Seus reduzidos tamanhos parecem expor suas insignificâncias. No entanto, em uma habitação arquitetônica, a funcionalidade

\footnotetext{
${ }^{72}$ Nomenclatura usada para definir um plano em que a câmera se localiza em altura mais elevada, acima dos olhos do personagem, e voltada para baixo provocando um sentido de rebaixamento.
} 
desses pormenores se estende da sustentação à movimentação. O detalhe une partes, sustenta, desloca, aciona e mantém a obra em pé.

E qual seria o papel dos pequenos objetos, dos detalhes, das miudezas no filme de Sebastián Borensztein? Em Um conto chinês, os pormenores estão no centro da narrativa. Eles estão nas manias de Roberto, na porta do quarto, na ordenação da loja de ferramentas, nas quinquilharias da casa. O detalhe está no limiar do funcional e do estético, entre a serventia e a inutilidade. Ora exibe sua materialidade em texturas, cores ou formas, ora expõe seu propósito na ação executada. Personagem, espaço e objetos se entremeiam e situam a narrativa no âmbito da interioridade. Tomado a partir da relevância dada a esses pormenores - sejam eles pequenos objetos ou fragmentos do espaço -, o filme viabiliza espacialidades entre personagens comuns, práticas cotidianas e objetos ordinários.
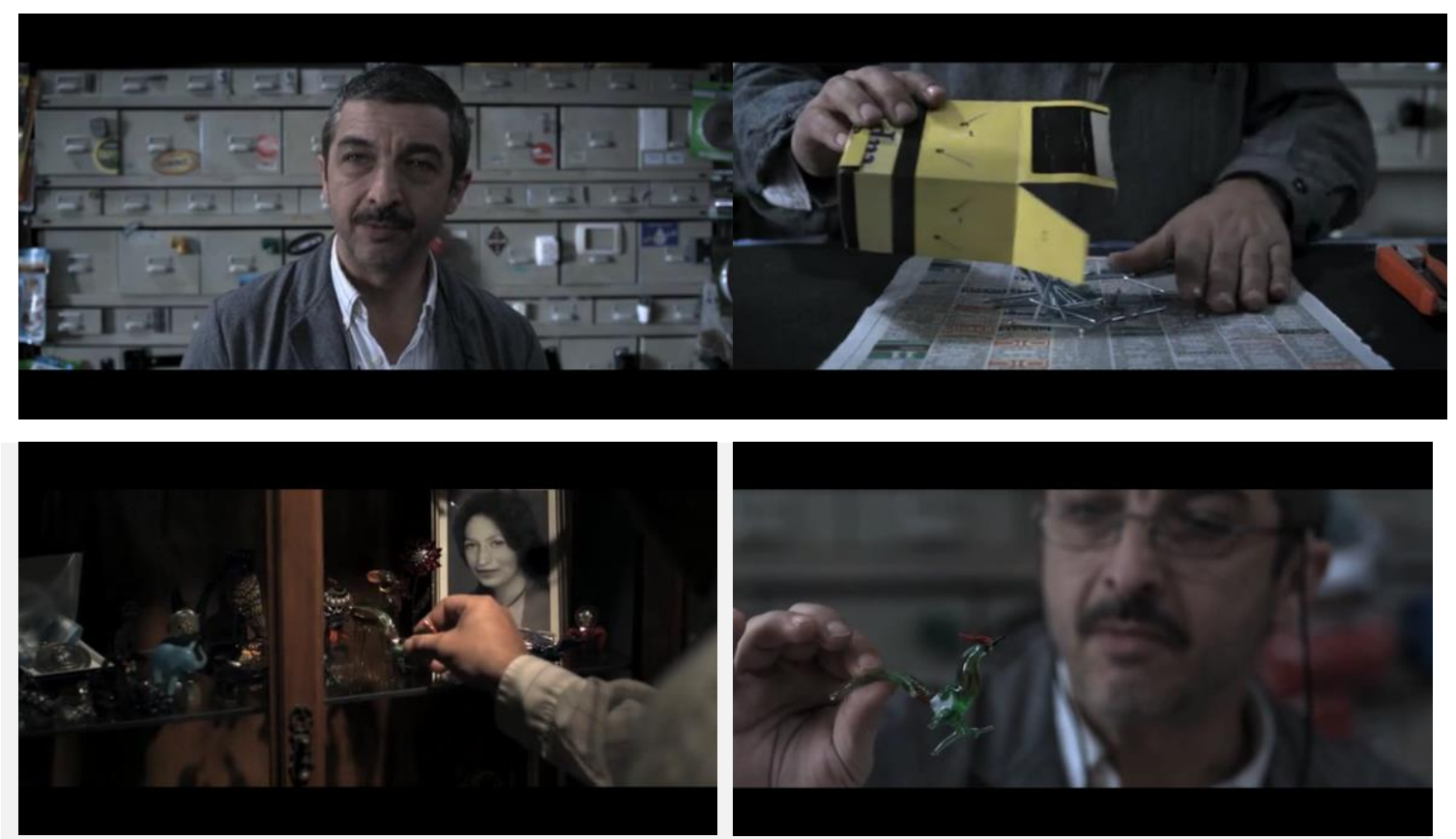

Quadro 07 a 10: O espaço da casa e o espaço do trabalho estão tomados por pequenos objetos.

As minúcias são o caráter do habitar cotidiano de Roberto. Ao manusear com intimidade esses pequenos objetos, ele reafirma sua personalidade como homem metódico. Suas práticas diárias giram em torno de pequenos objetos. Ele recebe a encomenda de um pequeno bibelô para presentear sua mãe falecida, e em sua movimentação, leva o espectador do ambiente do trabalho ao interior de sua casa. Ao atravessar a fronteira entre um espaço e outro com tanta permeabilidade, transforma ambos em um único espaço. Em sua loja de ferramentas, conta um a um os pregos da caixa, e sabe com certa precisão o peso de um conjunto deles; em casa, conserva e nutri as coleções de objetos familiares: cinzeiros, pratos decorados, bibelôs, etc. Casa e loja 
são duas partes de um mesmo habitar traçado na intersecção de formas de apropriação dos objetos cotidianos: na loja, os objetos têm funcionalidade, todos servem para algum fim; no espaço doméstico, perdem sua utilidade e se transformam em meros objetos de coleção.

As ferramentas e as quinquilharias ostentadas no ambiente doméstico de Roberto mostram bem mais do que uma composição cenográfica de um estabelecimento funcional. A pequenez, as minúcias estão expostas na cristaleira, na gaveta, nas estantes da loja, mas também na personalidade do protagonista; confundem-se com sua intimidade, com seu modo de habitar. Para além de sua representação como loja ou como casa, os objetos pendurados e posicionados nos recintos expressam características e manias: um homem metódico que segue uma ordem lógica da hora que acorda até a hora de dormir, minucioso, atento aos detalhes e aos pormenores. E mais ainda, permitem experimentar o filme como um modo de habitar instituído entre a casa e a loja, entre o todo e as partes, entre a ordem e a desordem, entre Roberto e Jun.

Na última sequência do filme, Jun vai embora e Roberto retorna a sua solitária vida habitual: levar flores para os pais no cemitério, preparar sua refeição, recortar notícias do jornal. As práticas diárias vistas nas imagens são as mesmas do início do filme e, ao se repetirem de forma ordenada, o inserem em um tempo e espaço contínuo afirmando sua inserção em um modelo narrativo do gênero cotidiano. Esta sequência poderia encerrar a narrativa, no entanto há um detalhe que precisa ser esclarecido: a personagem da vaca.

A vaca começa caindo do céu, inteira, encerrando a história na China e começando outra na Argentina. Depois é servida em pedaços, suas vísceras bem distribuídas em um prato oferecido para o desconhecido Jun. Mais tarde, o animal retorna em imagem fotográfica. A fotografia faz parte de um conjunto de imagens selecionadas e mostradas pela personagem Mari para apresentar ao chinês sua casa e sua família. A vaca tem dona, nome e singularidade: Olga, que quer dizer santa, sagrada, não é uma vaca qualquer, é a "vaca da Mari" e "é muito boa", diz. Na foto, a vaca está posicionada em primeiro plano. O enquadramento frontal posiciona Jun novamente diante de sua "antagonista". O reencontro suscita lembranças ruins e posteriormente, um pesadelo na intimidade do quarto. Tornando visível o animal, inteiro e fragmentado, indagamos o propósito de sua existência nessa narrativa. 

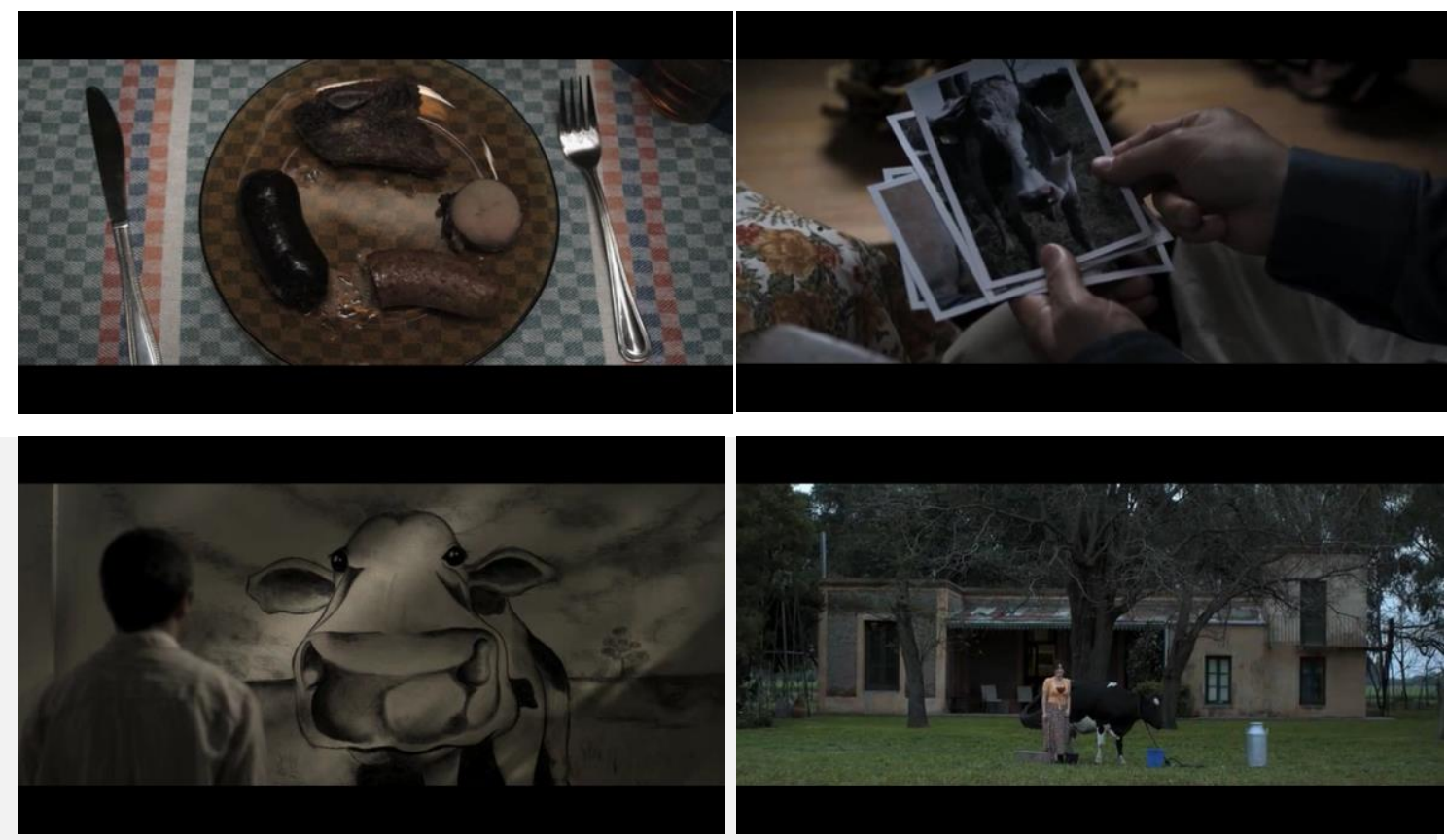

Quadros 11 a 14: inteira, em pedaços, desenhada ou fotografada, a imagem da vaca brinca com a noção de representação.

Logo antes de partir ao encontro de seu tio, Jun desenha a vaca de face no muro do pátio de Roberto. A vaca é o detalhe narrativo que estava faltando para elucidar essa história, a "dobradiça” que juntou Roberto e Jun e que vai levar Roberto a Mari. Os traçados no muro são como a tatuagem feita no braço do chinês, isto é, indica uma orientação. Na cena, Roberto e a vaca são filmados em um único plano. A diferença de escala sobrepõe o animal ao homem. Ela encara Roberto que está dentro do quadro, mas de costas. Entre eles, há como medir distâncias e proximidades. Roberto compreende o propósito da imagem deixada pelo estranho amigo e segue ao encontro de Mari.

A vaca ressurge no último plano do filme em frente à casa de Mari. Vaca e casa são pormenores, unem a trajetória de Jun e a de Roberto. Esses pequenos detalhes observados em proximidade se revelam "junções", afirmam a narrativa como um percurso de espaço erguido entre dois personagens distintos. E ainda, constitui o modo de habitar como espaço-ligação, um trânsito no "vão da escada", um trajeto "sobre a ponte". 


\subsection{Encontros e desencontros de Sofia Coppola}

Filme: ENCONTROS E DESENCONTROS

Título original: Lost in translation

Diretora: Sofia Coppola

Atores: Scarlett Johansson, Bill Murray

Nacionalidade: EUA

Ano de lançamento: 2003

Sinopse do filme: Charlotte é uma jovem americana recém-formada, habitando por tempo indeterminado com seu marido em um grande hotel da cidade de Tóquio. Hóspedes do mesmo hotel, Charlotte conhece Bob, um ator americano que vai à cidade para uma campanha publicitária. Os dois consolidam uma breve e profunda amizade.

\subsubsection{Charlotte e Bob habitam em um hotel}

A diretora Sofia Coppola começa sua narrativa privando o espectador de imagem. $\mathrm{Na}$ sequência inicial do filme Encontros e desencontros, uma tela preta aparece momentaneamente, ao mesmo tempo em que se escuta, em língua japonesa, a informação "bem-vindos ao novo aeroporto internacional de Tóquio". Uma imagem é excluída, entretanto o som esclarece o posicionamento espacial. A história tem um começo, e sua intenção é uma estratégia narrativa: informar a localização da história, ao mesmo tempo em que posiciona seus personagens: quem são e quais suas motivações.

Os protagonistas do filme Encontros e desencontros são Charlotte e Bob Harris. Charlotte é uma moça americana que mora em um hotel na cidade de Tóquio enquanto seu marido trabalha na região. Recém-formada em filosofia, não desfruta da autoconsciência de sua presença no mundo, é uma personagem em trânsito. Há uma inadequação entre ela e o universo que a cerca. "Escolhi ser uma escritora, mas odeio o que escrevo, e escolhi tirar fotografias, mas sou uma fotógrafa mediocre", diz a personagem. Bob Harris é um ator americano que vai à cidade para atuar em uma campanha publicitária japonesa. Casamento frustrado, profissão em declínio, após o nascimento dos filhos, "sua vida, tal como a conhecia, se vai para não voltar mais". Bob é também um personagem em trânsito. Transita na crise da meia idade, entre ser uma celebridade e cair no esquecimento, entre uma vida feliz e uma existência de descontentamentos. Deslocado de tudo, incapaz de se integrar à realidade em sua volta, tem em suas aparições uma desconformidade às proporções do local onde se encontra: bem mais alto do que os japoneses no interior do elevador, desproporcional à escala do chuveiro do quarto do hotel, ao tamanho dos chinelos oferecidos aos hóspedes. 

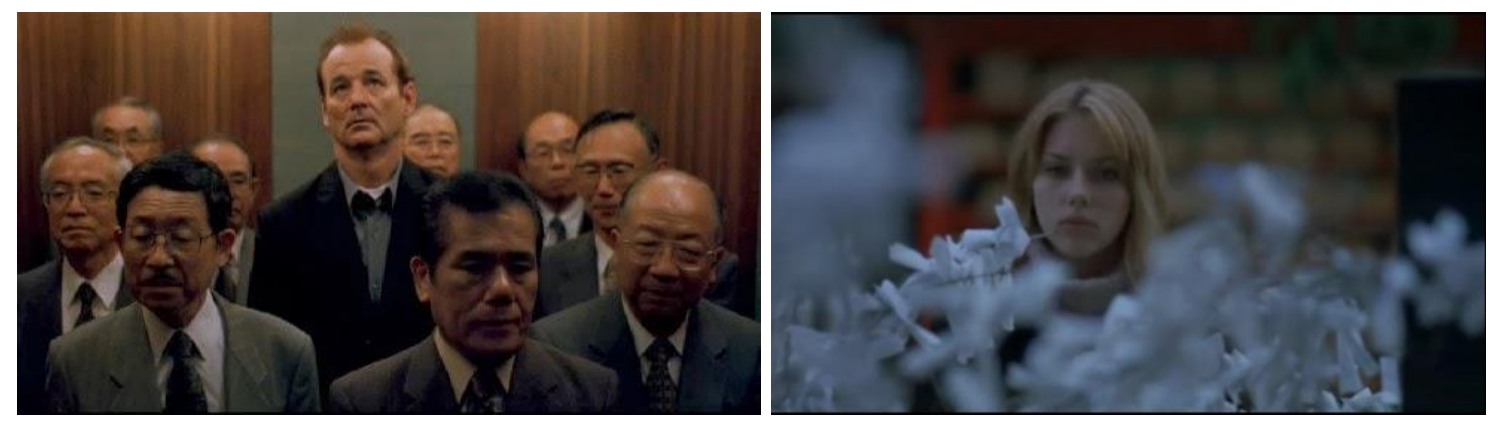

Quadros 15 e 16: personagens cosmopolitas inseridos em espaços de trânsito.

Personagens cosmopolitas posicionados, narrativa espacializada no Park Hyatt Hotel e na cidade de Tóquio. O tema central desse filme é a transitoriedade. Sua topografia fílmica conduz a este entendimento. Personagens e lugares são permeados pelo atributo do provisório, do efêmero, do passageiro. O modo de habitar dos protagonistas se relaciona com o caráter do lugar - um espaço de trânsito -, provocando uma orientação e identificação. Quando se pondera uma orientação, pensa-se na posição que ocupam e no direcionamento tomado pelos personagens na história narrada; quando se define uma identificação espacial, o que importa é o modo como se apropriam dos lugares e erguem seus mundos pessoais, constituídos também nas relações com outros personagens.

Em ambos, o universo ficcional dos personagens se constrói no cruzamento entre o espaço do hotel e a cidade japonesa. O hotel se compõe de fachada apresentada como lugar oponente, hall de entrada pleno de fluxos de chegadas e partidas, a piscina, os corredores, o elevador e o restaurante onde acontecem os encontros, e também os quartos dos hóspedes. A cidade são as ruas por onde transitam os personagens, bares e restaurantes, um hospital, os locais das baladas, e os cenários japoneses por onde Charlotte trafega de modo ininterrupto. Nesta narrativa, quase não há espaços fixos, os lugares são "pontes" e "escadas". São como espaços-ligação, afiguram a expressividade de seus personagens em estados de transição. A experiência de mobilidade da sociedade contemporânea incide nos modos de habitar dos protagonistas-cosmopolitas do filme. São todos plenos de transitoriedade.

Nesse mundo, todos os habitantes são nômades, mas nômades que perambulam a fim de se fixar. Além da curva, existe, deve existir, tem de existir uma terra hospitaleira em que se fixar, mas depois de cada curva surgem novas curvas, com novas frustações e novas esperanças ainda não destroçadas (BAUMAN, 1998, p.92).

Zygmunt Bauman nos diz que os nômades são arrivistas, "alguém já no lugar, mas não inteiramente do lugar, um aspirante a residente sem permissão de residência" 
(ibidem). Charlotte e Bob são arrivistas, estão no Japão mas não são de lá. A constituição de um modo de habitar, nesse filme, pondera a divergência entre as duas preposições: no e do. A primeira admite a passagem, o estado provisório, enquanto a segunda é pertencimento. Ambos os personagens não pertencem ao local onde se encontram. $\mathrm{O}$ Japão é para um ocidental o sentido maior da estrangeiridade. Se pertencer a um lugar significa seu reconhecimento, a cultura japonesa afirma aos americanos um nãopertencimento, evidenciado pelo filme nas diferenças de proporção entre personagem e espaço, na falta de comunicação entre protagonistas e personagens japoneses, na cumplicidade imediata de Bob e Charlotte, na falta de adaptação ao fuso horário japonês, mas principalmente no olhar de estranhamento de ambos diante da "paisagem"73 japonesa e sua cultura.

Há uma perda provisória de identidade, uma anomia que encerra os personagens em um estado de desconforto, incertezas e solidão. Ao mesmo tempo, o filme ressalta uma compatibilidade entre o modelo de personagens cosmopolitas - gente que se desloca o tempo todo - e o hotel, entendido como espaço-ligação entre uma partida e uma chegada $^{74}$. Entretanto o hotel não é o mesmo para Bob e para Charlotte. Enquanto para o primeiro o lugar é uma hospedagem breve, para a jovem o hotel é uma condição transitória permanente. Ao igualar personagem e espaço em um fluxo ininterrupto, a narrativa se fecha para um sentido de interioridade transmutando o Park Hyatt Hotel em um modo de habitar transitórios.

No filme de Sofia Coppola, os personagens se definem no âmbito do outro, no espaço de alteridade. Bob e Charlotte tecem relações estreitas em um mundo compartilhado. A relação com o espaço do outro explicita as diferenças e semelhanças entre eles. Aqui, olhar o outro é uma forma de olhar a si mesmo. Aparentemente, Bob e Charlotte são personagens antagônicos. Bob é um ator famoso; Charlotte, uma imigrante desconhecida. Ele, onde quer que transite, é sempre reconhecido; ela circula anônima pelos lugares. Ele, um homem de meia idade prestes a se aposentar; ela, uma jovem recém-formada em busca de uma profissão. Dois universos disjuntos, polarizados por características opostas e com algo em comum: estão em trânsito em um país estrangeiro, vivendo um momento transitório.

\footnotetext{
${ }^{73}$ Paisagem no sentido dos cenários observados, as vistas da cidade, os planos ambientes mostrados enquanto circulam pelas cidades japonesas.

${ }^{74}$ É bom lembrar que o filme começa com a chegada de Bob a Tóquio e termina com sua partida.
} 
O hotel é um espaço propício ao encontro. É um ponto fixo, um edifício, mas seu agenciamento é móvel, feito de fluxos, de pessoas que circulam. A configuração do hotel direciona a relação entre os personagens: um local de passagem, uma história fugaz, um encontro breve. A interação entre personagens se dá, inicialmente, nos espaços do hotel. Encontram-se pela primeira vez em trânsito, dentro de um elevador. Ali, o sorriso de Charlotte revela certa cumplicidade. Em um elevador repleto de japoneses, dois ocidentais têm certamente muito em comum. Apreendidos em uma topografia fílmica, os espaços-ligação, como os corredores e elevador, e os espaços de convívio, como a piscina e o restaurante, incentivam trajetos e a circulação de hóspedes. Nesse movimento, Charlotte e Bob transitam pelos ambientes e traçam suas narrativas em pontos de encontro. Nos espaços do hotel, também se cruzam Charlotte e seu marido, jovem fotógrafo que tem pouco tempo para se dedicar à esposa. No restaurante, no hall de entrada, no quarto não partilham dos mesmos interesses. Estão sempre se distanciando, em momentos de despedida, um dormindo e o outro acordado.

O jogo de distanciamentos e aproximações entre os personagens se estende aos meios e sistemas de comunicação presentes na narrativa. Aqui, as relações sociais não dependem de uma proximidade física para acontecerem, são conduzidas também a outros locais de interação. A comunicação com o outro se dá através de mídias multifuncionais, fax, telefone, correio, que não reforçam os elos sociais. $\mathrm{O}$ fax que recebe as mensagens da esposa não contribui para aproximá-la do marido, local e sentimentalmente distante. Um telefonema para a amiga que se encontra em outro país, não resolve o problema de solidão de Charlotte, os programas de televisão exibidos durante a madrugada não preenchem o vazio noturno.

\subsubsection{O quarto e a cidade - exterior e interior}

Um quarto é um mundo pessoal, o espaço doméstico onde a apropriação cria um território particular. Se a casa é um espaço íntimo, o quarto é o âmago dessa intimidade. Espaço geralmente reduzido e fechado, impõe privacidade. Longe de olhares externos, o quarto revela o universo interior do habitante: quem são, o que sentem, o que desejam. $O$ hotel é um mundo impessoal, se oferece como distanciamento e trégua da vida de todo dia. Mas no hotel, há o quarto. Agenciado pela transitoriedade de hóspedes que se alternam, o quarto de hotel é, para cada um deles, um canto de repouso, um local para dormir após um dia de andanças, de passeios ou trabalho. A apropriação de um quarto de hotel se inicia no ato de adentrar ao recinto. Ao receber a chave na recepção, o novo 
proprietário transmuta um quarto de hotel em espaço privado que particulariza e preserva o hóspede no cerne do espaço hospitaleiro.
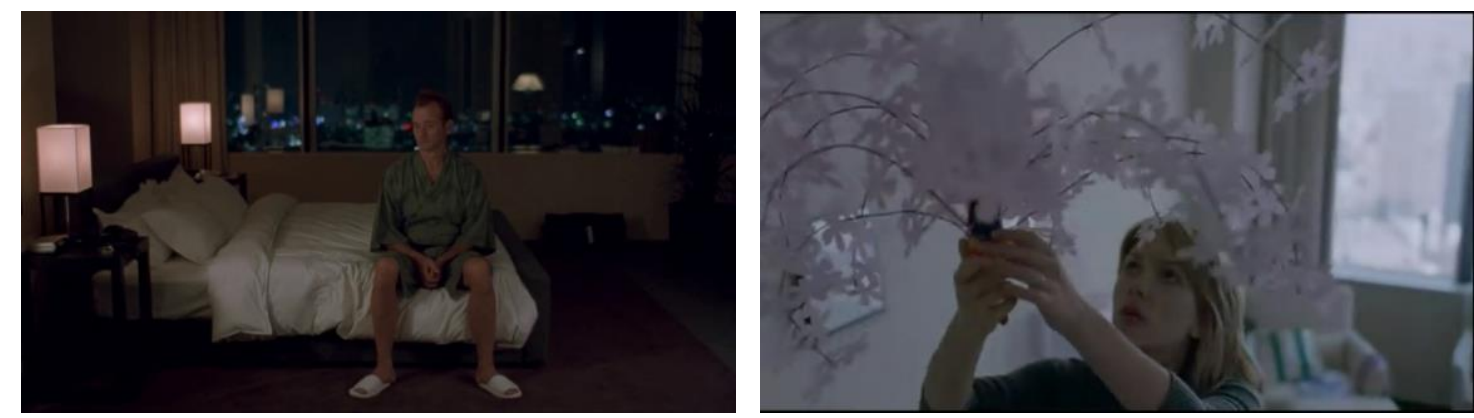

Quadros 17 e 18: o quarto não cumpre sua função como dormitório, é apropriado para outros fins.

Em Encontros e desencontros, o quarto do hotel é o espaço do "mundo pessoal" dos protagonistas, onde se localizam com suas individualidades. Ali, convivem consigo mesmos, revelam seus segredos, habitam o quarto intimamente. A função básica de um quarto é dormir, mas no filme de Sofia Coppola, essa funcionalidade não é obedecida. No Park Hyatt Hotel, o quarto não é um lugar para dormir. A cama aqui serve somente para confidências. Devido à diferença de fuso horário entre os Estados Unidos e o Japão, Charlotte e Bob não dormem. O tempo deles está localizado do outro lado do mundo. Esse desencaixe reforça uma desarticulação entre personagens e entorno: estrangeiros, personagens em trânsito, inadequados ao espaço que habitam.

Charlotte e Bob colocam suas próprias marcas e, como os caminhantes de Michel de Certeau, transformam o quarto, criando uma "organicidade móvel do ambiente". A multiplicidade de suas ações, e o modo como as espacializam em seus quartos desvendam a complexidade desses personagens, ao mesmo tempo em que edificam um relato cotidiano estruturado na "maneira de organizar o espaço disponível, por exíguo que seja, e de distribuir nele as diferentes funções diárias (refeições, toalete, recepção, conversa, estudo, lazer, repouso)" (1997, p.204). No quarto de hotel, Charlotte faz tricô, escuta CD de autoajuda, analisa suas fotos, decora o ambiente com flores artificiais, enquanto Bob vê televisão, joga golfe e se entedia. Ali, a narrativa se organiza em práticas cotidianas, em ações banais que domam o espaço impessoal em estados inconscientes de introspecção: os personagens parecem não ter consciência de seus atos, apenas os executam. Nada do que se passa nesses ambientes aparenta ter importância, as insignificâncias apenas ajudam a passar o tempo, um tempo do cotidiano. 
Enquanto o quarto é um espaço interior, a cidade se define como exterior, porém, a polaridade interior-exterior, aqui, é duvidosa. Os espaços externos se fecham para um sentido de interioridade: a cidade é apreendida pela visão de estrangeiros, seja nos enquadramentos das janelas do hotel, seja nas sequências de peregrinações dos personagens pelas ruas, templos e cenários japoneses. A localização do hotel no centro de Tóquio é evidenciada pela imagem da cidade vista em profundidade de campo do alto dos espaços hoteleiros. De cima, Tóquio parece uma maquete, passível de dominação. Não há inversões entre personagem e espaço, a perspectiva filmada não vem de fora para dentro, mas do interior para o exterior. É a imagem de Charlotte que se sobrepõe à da cidade.

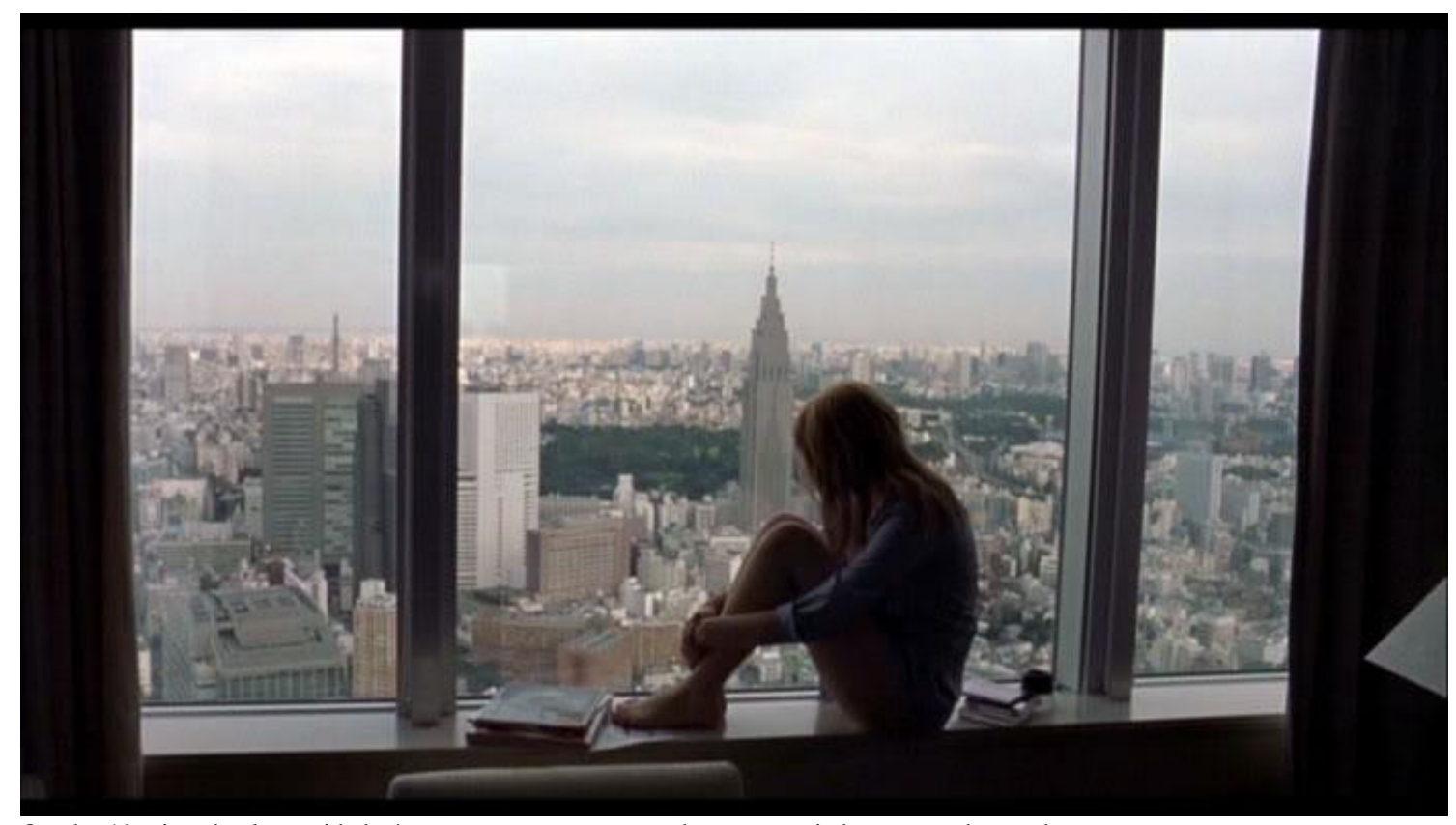

Quadro 19: vista do alto, a cidade é uma maquete que não pode ser apropriada, apenas observada.

Do espaço íntimo, a cidade é revelada em transparência. Através do vidro da janela, o exterior se torna visível; uma permeabilidade visual que ora enfatiza a distância entre personagens e lugar, ora os une em uma única imagem. Em ângulo plongée, a cidade é silenciosa, parece dominada, apropriada em um quadro. Ali, é uma paisagem, uma panorâmica estática, uma vitrine de mundo urbano. O vidro deixa transparecer a cidade enquanto reflete o espaço interno do quarto. Dentro e fora são afigurados em um mesmo plano, assim, Sofia Coppola unifica espaço e personagens, funde paisagem estrangeira e estrangeiros, dissolve a grande cidade às minúcias do universo íntimo.

Se a cidade vista dos espaços internos do hotel torna a metrópole menos vasta, nas sequências exteriores ela é filmada na altura dos olhos, percebida de igual para igual. 
Após a chegada ao aeroporto de Tóquio, o filme apresenta o personagem Bob em trânsito. De dentro de um táxi, Bob observa a metrópole: luzes, edifícios, habitantes, outdoors. Aqui, a conjunção entre sujeito e mundo ambiente se dá no movimento. As imagens da cidade, diferentemente dos enquadramentos do interior do hotel, são de mobilidade: ou os habitantes estão em deslocamento ou a cidade aparece em movimento. As metrópoles são dotadas de um dinamismo próprio, mas para Sofia Coppola, seu movimento é uma unidade relativa provocada pela visão dos personagens que estão em trânsito. Mostrada em planos gerais, Tóquio se apresenta em paisagens repletas de fluxos, espaços abertos tomados por habitantes em deslocamento. A dicotomia entre unidade e multiplicidade, entre escala humana e escala urbana é vista em enquadramentos que misturam os protagonistas aos habitantes de Tóquio. Nas grandes cidades, somos únicos e ao mesmo tempo, muitos.

Em sua chegada, Bob vê sua imagem exposta em um grande outdoor colocado no meio da rua. Bob é um personagem visível, quanto mais exposto, mais presente. Por outro lado, Charlotte é um ser invisível, ela passa anônima pelas ruas da cidade. Tóquio é uma só, mas a narrativa de cada personagem demarca um modo próprio de habitar o espaço urbano. Cada personagem traça um percurso de espaço. Para Charlotte, a cidade aparece como lugar de deambulação: "arquitetura da passagem, feita para o habitante em trânsito da metrópole. Sucessão de formas, sobreposição espacial, sequência de lugares sem laços aparentes", citando o arquiteto Brissac Peixoto (2003, p. 377), que reconhece o percurso mais importante que as edificações.

Charlotte percorre as paisagens da cidade em continuidade, num caminhar sem fim: de metrô, de trem, a pé... à deriva. A jovem não tem ponto de chegada, se encontra em um momento transitório que não passa nunca. Charlotte cruza as pedras sobre o riacho, e segue seu caminho. Ela atualiza suas possibilidades de andanças à medida que caminha. Em seus passos, há ordem e desordem. A personagem anda à deriva, sem uma finalidade que a conduza. Ela abdica de qualquer motivo para se deslocar. Na cidade, Charlotte apenas se desloca e observa, observa e se desloca. A observação do mundo que a cerca é confrontada com a dificuldade de uma auto-observação. Sem consciência de si mesmo, Charlotte tenta tomar consciência do universo que a cerca. 

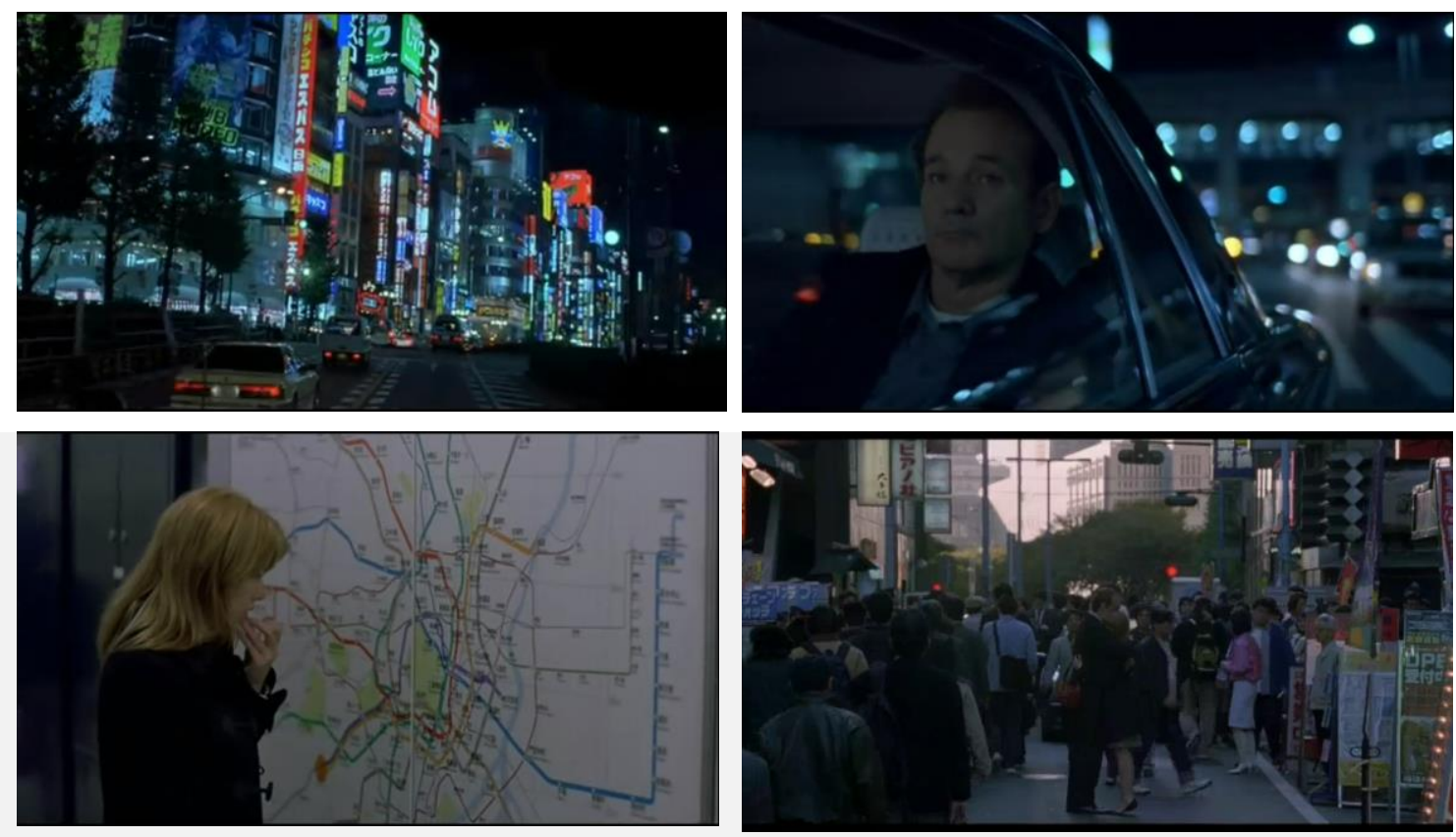

Quadros 20 a 23: Tóquio, em imagens-movimento, é uma metrópole apreendida em fluxos de circulação e pontos de cruzamento.

Bob e Charlotte habitam o mundo fictício da narrativa em uma experiência de deslocamento: um está de passagem, o outro apenas passa. Juntos, circulam a esmo pela cidade: vão a festas, bares, boates, circulam. Suas trajetórias pessoais se cruzam em uma tentativa de fazer pulsar um espaço que não se pode transpor: a cidade estrangeira. $O$ habitar do estrangeiro em outro país passa pelo esforço de pertencimento. Ainda que se dê conta de não pertencer àquele lugar, o estranho habitante toma a cidade para si. Se Bob é visitante e não se adequa ao espaço alheio, Charlotte em seu caminhar acessa a cidade ao seu modo, dela faz seus itinerários, traça sua própria cartografia urbana. A estreiteza de suas individualidades reduz a amplitude da cidade, que é uma para cada morador, mas que no filme se faz na interseção de percursos de espaço.

Uma narrativa é feita de partes que compõe o todo. E o todo, aqui, tem princípio, meio e fim. Na última cena do filme, Bob Harris está de partida, mas ainda não está pronto para ir embora. De dentro do táxi, ele avista Charlotte caminhando pelas ruas da cidade. Ele para o carro e vai atrás dela. Em meio ao fluxo urbano, eles se aproximam e se abraçam. Dizem-se adeus e Bob parte. Para ele, o percurso tem um fim: ele viaja de volta para casa. Mas para Charlotte, a jornada continua. A moça segue sua caminhada e se perde em meio a tantos outros habitantes da cidade. Em Encontros e desencontros, a cidade e o hotel são os espaços narrativos que concebem modos de habitar de personagens em trânsito, topografias fílmicas erguidas em fluxos, em permanências e transitoriedades. 


\subsection{Louise Wimmer de Cyril Mennegun}

Filme: Louise Wimmer

Diretora: Cyril Mennegun

Atores: Corinne Masiero, Jérôme Kircher, Anne Benoit

Nacionalidade: França

Ano de lançamento: 2003

Sinopse do filme: Após sua separação e na véspera de completar cinquenta anos. Louise, sem uma casa para viver, se vê obrigada a morar em seu carro. Enquanto aguarda na fila por uma habitação social, ela sobrevive de trabalhos incertos e de relações instáveis.

\subsubsection{Louise mora em um carro}

Se no primeiro filme analisado o modo de habitar parte do imaginário da casa como espaço fixo, e no segundo, o hotel é também morada em uma interseção entre permanência e passagem, neste a casa é somente ausência e o espaço do habitar (o carro), a concretude da transitoriedade. Em Louise Wimmer, o tema dominante é a instabilidade. A personagem se encontra em um estado transitório entre o fim de um casamento e um novo lugar para morar. Sua precariedade se materializa em diversas instâncias: nos subempregos que executa, nas dívidas financeiras, em seus relacionamentos amorosos, no lugar onde dorme. A protagonista é uma cosmopolita e por isso experiencia as dinâmicas de uma sociedade urbana apreendidas no imaginário de narrativas ficcionais que retomam não apenas as mobilidades e os fluxos da globalização, mas também as sequelas sociais e econômicas da contemporaneidade.

Como Sofia Coppola, o diretor Cyril Mennegun começa sua narrativa apresentando os créditos do filme sob uma imagem escura onde apenas o som é perceptível. Ruídos de veículos transitando ao longe localizam a sequência inicial em uma estrada qualquer. É noite, e as luzes de um carro surgem em profundidade de campo se aproximando aos poucos até sua saída de quadro em primeiro plano. Em seguida, vista pelo retrovisor do carro, Louise aparece chorando e dirigindo seu carro. Os planos são primeiríssimos planos (big-close), o que restringe o espaço ao rosto de Louise e às luzes abstratas fora de foco. Do pouco que se vê, apreende-se um sentido de vulnerabilidade. O filme tem um começo e sua intenção é aderir à primeira imagem a síntese de sua narrativa: Louise vulnerável transitando em seu carro.

Louise sonha em ter uma casa própria. Sua busca se evidencia na insistência junto à assistente social para conseguir uma moradia. Enquanto isso, Louise mora em seu carro. Seu desamparo aparece nos lugares a esmo em que a moça estaciona seu carro: em ruas 
desertas, em postos de gasolina, em estacionamentos vazios. Habitar em um carro é deambular constantemente, é usufruir de uma condição transitória permanente. O carro serve para transportar, aí se volta à funcionalidade dos espaços e questiona-se o carro como moradia. Uma vez que a rua é um espaço-ligação, o carro é a própria "ligação", é aquilo que conduz de um ponto a outro, o que permite atravessar a ponte. Se o carro é a essência da mobilidade e o caráter da casa é a fixidez e a segurança, habitar um carro seria um contrassenso.

Os modos de habitar da contemporaneidade são apreendidos na dinâmica urbana, e o carro é a experiência plena da itinerância na cidade. $O$ urbano passa pelos espaços de tráfego, por espaços-ligação que levam os habitantes de um edifício a outro, como as ruas, as avenidas e as vias. Porém, em Louise Wimmer, a rua não é passagem entre lugares, a rua é onde tudo acontece, o espaço da deriva apropriado pela personagem, uma autêntica "moradora de rua". O lugar real apreendido pelo filme - uma rua qualquer - é apropriado e transmutado em espaço narrativo onde o carro de Louise circula e estaciona. Algumas características referenciais são identificadas na representação, porém sua percepção como elemento narrativo extrapola uma simples realidade física e se impõe como um modo de habitar desenraizado e ao mesmo tempo indesejado.

Ter uma casa é existir como um ser-no-mundo. A casa como lugar provoca a identificação e a orientação. Aqui, quem não tem casa é um ser desorientado em estado de anomia. Louise é uma personagem desamparada, desenraizada. Sua existência se reduz ao transitório, ela é metamorfose ambulante. O carro é o lugar central de sua existência, e a casa é seu ponto de chegada. Ainda que mantenha um compromisso com a aparência real, o diretor Cyril Mennegun filma personagem e carro como um quadro cubista: em seus planos há um pouco de Louise e um pouco de carro, juntos formam um todo. Não é em sua concretude que o carro se define, mas na relação com sua proprietária. Eles são filmados de todo jeito, de longe, inteiros, decompostos, em plano frontal, em movimento, estacionado na rua. 


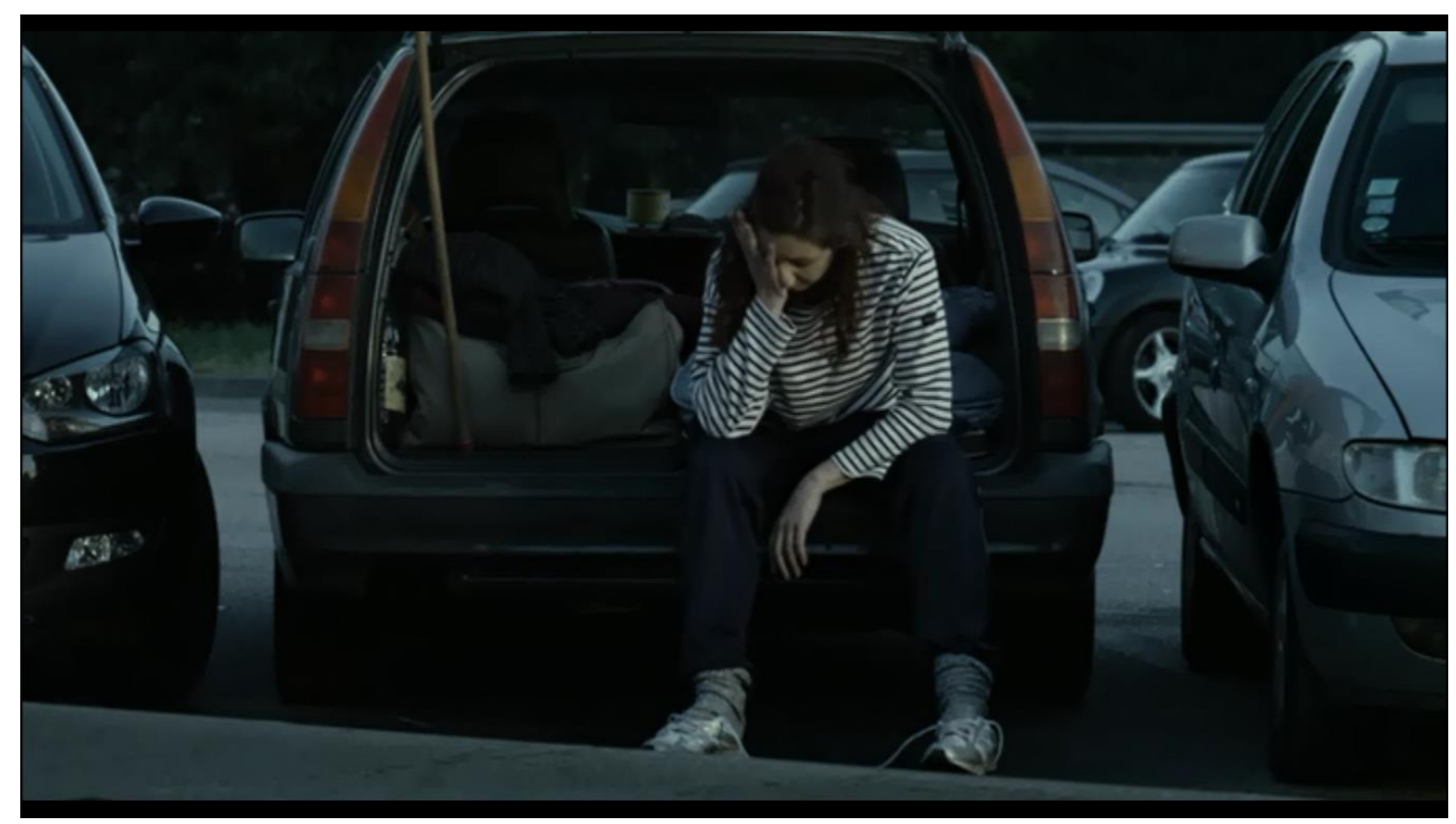

Quadro 24: personagem e carro se igualam em estado de provisoriedade e instabilidade.

O carro é tudo que lhe resta; quando ele falha, Louise diz: "você não vai me deixar também!"75 A debilidade de um reflete na precariedade do outro. Louise não tem dinheiro, deve em todo lugar, dissimula para se alimentar, rouba gasolina de veículo alheio, não tem emprego fixo; seu carro tem problemas no motor, dá pane em lugar inapropriado, a porta traseira se mantém aberta com a ajuda de um cabo de madeira. Aqui retoma-se o sentido de ser-em do filósofo Martin Heidegger (2005a): o modo de habitar implica em uma inter-relação entre carro e Louise, de tal modo que a ausência de um põe em risco a conservação do outro.

\subsubsection{Interior e exterior}

No filme Louise Wimmer, um veículo assume o sentido de residência, mas como tal, o carro não é um lugar apropriado para morar. As práticas cotidianas como comer, dormir, se higienizar costumam ser espacializadas em cômodos apropriados no interior do espaço doméstico. A cozinha é o lugar para preparar o alimento, o quarto é o canto do repouso e o banheiro permanece como o local dos atos higiênicos. O imaginário é desafiado pela narrativa no deslocamento das ações domésticas da protagonista para outros lugares. Louise dorme no carro, se alimenta em locais variados, faz sexo na cama

\footnotetext{
75 "Tu ne vas pas me lacher, aussi toi". N.T.
} 
alheia, e toma banho em banheiros públicos. Há uma reconfiguração do habitar como lugar concentrado e cercado.

Ao retomarmos a visão de Christian Norberg-Schulz (2008, p.448) do lugar como interior cercado e concentrado, reunindo o que é conhecido, procura-se perceber o carro de Louise como um modo de habitar diferenciado. $\mathrm{O}$ ato de reunir funções diversas em um espaço delimitado faz parte de uma ideia costumeira de casa. $\mathrm{O}$ banheiro, o quarto, a sala, a cozinha, ficam sobre o mesmo teto e costumam fazer parte de um único domicílio. Quando se pensa em uma residência, ninguém ousaria se deslocar de um lugar a outro para tomar banho, dormir ou se alimentar. A concentração de grande parte das atividades cotidianas afirma a casa como espaço essencial para a conservação da vida.

Ao colocar uma personagem morando em um carro, um espaço restrito e apropriado para outro fim, o filme reconfigura as dicotomias espaciais entre o dentro e o fora e desarticula um modelo rígido para se conceber lugares em narrativas cinematográficas de ficção. Em sua leitura sobre as construções dos homens, NorbergSchulz diz que para cumprir a função de cercamento, "os lugares contêm aberturas através das quais se ligam com o exterior" (ibidem). Um carro é um pequeno espaço cercado, porém aberto plenamente à visibilidade externa. De seu interior, Louise vê carros passando, pessoas a encarando, mas também a chuva caindo. A fronteira interior-exterior de um carro é uma fina linha demarcadora; quanto mais visível o exterior melhor se presta um veículo a seu fim.

As sequências em que Louise procura repousar no interior do carro são um contrapeso ao que esse espaço possa oferecer como espaço doméstico. A personagem sofre para dormir: as luzes e os ruídos de outros veículos trafegando nas pistas invadem constantemente o espaço interior onde a moradora tenta adormecer; na janela, uma cortina improvisada serve como lembrete de um espaço mal apropriado para outra finalidade; às vezes dorme deitada no espaço de trás, em outras tenta cair no sono, sentada no banco da frente. Essas cenas denunciam a necessidade da casa como lugar protegido e resguardado do que vem de fora. A porta fechada é uma barreira entre o dentro e o fora, mas a visibilidade das janelas deixa vazar na transparência tudo o que está se passando nas ruas. Nesse sentido, o carro não é uma boa fronteira, nem uma boa casa.

Ainda que as ruas sejam lugares de mobilidades, o carro de Louise circula pouco, está mais para espaço fixo do que objeto móvel. Parece haver uma inversão nos modos de usar, na apropriação das coisas e dos lugares: os objetos pessoais de Louise ficam guardadas "fora de casa", o secador de mãos do banheiro público se transforma em 
secador de cabelo, o meio da rua serve como lugar para a troca de roupa, o banheiro da casa alheia é o lugar para se fazer bela. A "re-apropriação" dos espaços no universo de Louise abre um caminho para pensar práticas desterritorializadas da sociedade contemporânea. Ao tomar o carro por um espaço doméstico, o filme repõe um imaginário dos espaços atuais para se habitar e suas novas apropriações pelos homens cosmopolitas. Quem se desloca o tempo todo precisa renegociar suas ações habituais a novos lugares, principalmente engendrando-as com uma mobilidade demasiada.
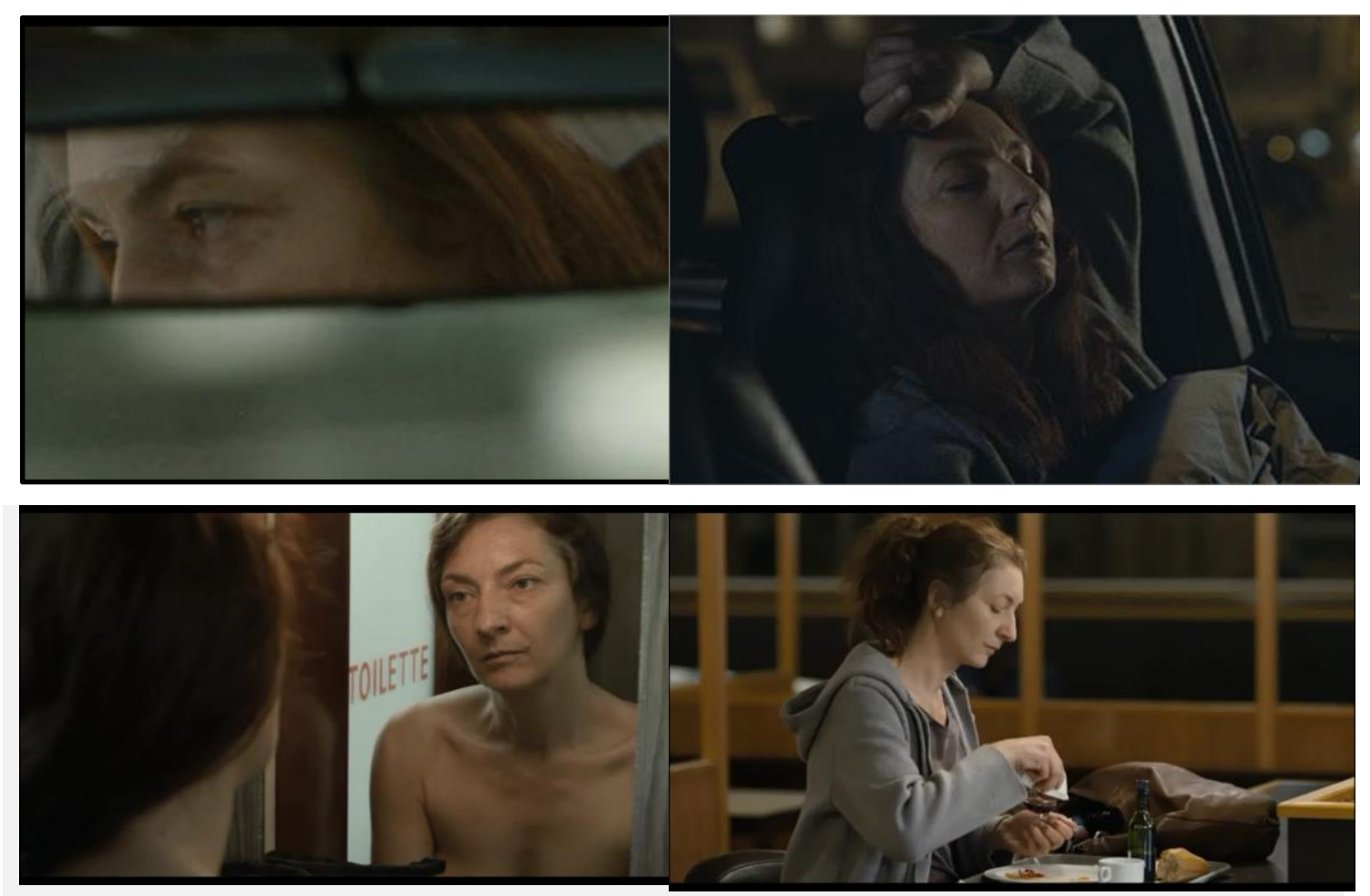

Quadros 25 a 28: O espaço de dentro não é um lugar abrigado, onde o sujeito encontra acalento e repouso. Ao mesmo tempo, as práticas domésticas como comer e tomar banho são realizadas em espaços externos.

No interior do carro, o retrovisor dá o contraponto da angústia de quem não tem onde morar. Ele é o fragmento arquitetônico, o detalhe narrativo que contrapõe a imagem do exterior e o mundo íntimo da personagem. O filme de Cyril Mennegun privilegia o espaço existencial, aquele ocupado pelo sujeito. A cidade, a rua, o tráfego urbano, são elementos secundários. $\mathrm{O}$ diretor funda sua narrativa na instância da intimidade, naquilo que individualiza a personagem, convidando a uma interiorização. Ao utilizar, com frequência, planos aproximados e centralizados na personagem Louise, ele reduz o espaço do ambiente para se cercar dos desejos, dos sentimentos e conflitos vividos pela protagonista. A contextualização da história é quase inexistente, ela poderia se passar em tantas outras cidades do globo terrestre. O mundo da intimidade é favorecido ao espaço 
da alteridade: sua relação com os demais personagens é superficial e a relação familiar se limita a uma única sequência. O modo de habitar aqui é um espaço solitário, não como identidade fixa, mas como itinerário que se constrói à medida que Louise se desloca. A narrativa questiona as possibilidades expressivas de espaços, lugares e coisas, oferecendo ao espectador formas transitórias para se perceber outros modos de se habitar o espaço urbano.

\subsubsection{A ausência da casa}

A casa é o mote dessa narrativa, o que faz mover a história e sua personagem, no entanto ela não aparece em momento algum. Sua ausência é o que reforça sua presença. Se dentre os filmes selecionados, há algum que delineie melhor a casa como uma experiência fenomenológica, este filme é Louise Wimmer de Cyril Mennegun. Apagar a casa em sua materialidade, em portas e janelas, em paredes e telhados, em cores e formas, e erguê-la em visibilidades e transparências, em transitoriedades e apropriações, em sentidos e subjetividades, é o que determina o carro de Louise como um modo de habitar da contemporaneidade.

Em tempos de mobilidade exacerbada, a casa tradicional aparenta desaparecer como espaço doméstico para se habitar. O caráter nômade e fluido das sociedades globalizadas viabilizam outros modos de edificar os espaços domésticos. As pessoas desestruturam formas e funcionalidades dos cômodos, abrem a sala para a cozinha, colocam cozinhas dentro de quartos, deixam os banheiros à vista, abrem paredes e deslocam janelas e portas. A casa também se desloca, ganha transitoriedade, passa a ser reversível, ora é uma coisa, ora outra. O território passa a ser uma abstração, um espaço itinerante e desenraizado.

Os cosmopolitas que trafegam incessantemente adaptam objetos e práticas cotidianas a lugares móveis para não serem obrigados a parar instante algum, tornando a morada uma arquitetura errante. Há um desespero em se apropriar de tudo a todo instante, a casa então vaza um pouco em cada canto. A narrativa de Louise retoma a construção da casa não no que ela tem de figurativo, mas no que ela tem de espaço imaginário, como lugar da sobrevivência, do bem estar, da relação com o outro.

A falta da casa representa para Louise mais do que a ausência de um abrigo. Aqui, pensa-se no habitar como uma ponte em alusão à Martin Heidegger. Em seus ensaios, o filósofo relaciona o habitar a construir, tomando como referência a imagem da ponte. 
"Ambos os modos de construir - construir como cultivar, em latim, colere, cultura, e construir como edificar construções, aedificare - estão contidos no sentido próprio de bauen, isto é, no habitar" (2008, p.127). Um construir que possibilita edificar, e edificar é dar estrutura, é proporcionar espaços de convívio e de intimidade, e é também dar passagem e reunir. Sem a casa, Louise se encontra desprotegida, solitária, dispersa. Ela se apropria dos espaços alheios, dos lugares públicos e do que é dos outros (gasolina, comida, dinheiro) para dar conta de sua sobrevivência diária. Seu modo de habitar se constrói na instabilidade, mas também no que pertence aos outros, naquilo que é de todos, edificando um habitar de forma desconjuntada.

Para Heidegger, o habitar é o traço fundamental do homem, enquanto o caráter fundamental do habitar é o resguardo. Habitar é ter um canto para se resguardar, mas não somente o resguardo do corpo, mas das coisas, das memórias, dos afetos, da imaginação. A metáfora da ponte retorna aqui no sentido existencial do habitar. A ponte é construção não apenas porque une uma margem a outra, mas porque integra as partes e dá sentido ao todo. "A ponte se estende lépida e forte sobre o rio. Ela não junta as margens que já existem, as margens é que surgem como margens somente porque a ponte cruza o rio" (ibidem, p. 131). Para existir, o homem precisa atravessar a ponte. É no percurso que ele se dá conta de seu todo. Se permanecer estagnado em uma das margens, o homem não constrói nem habita.

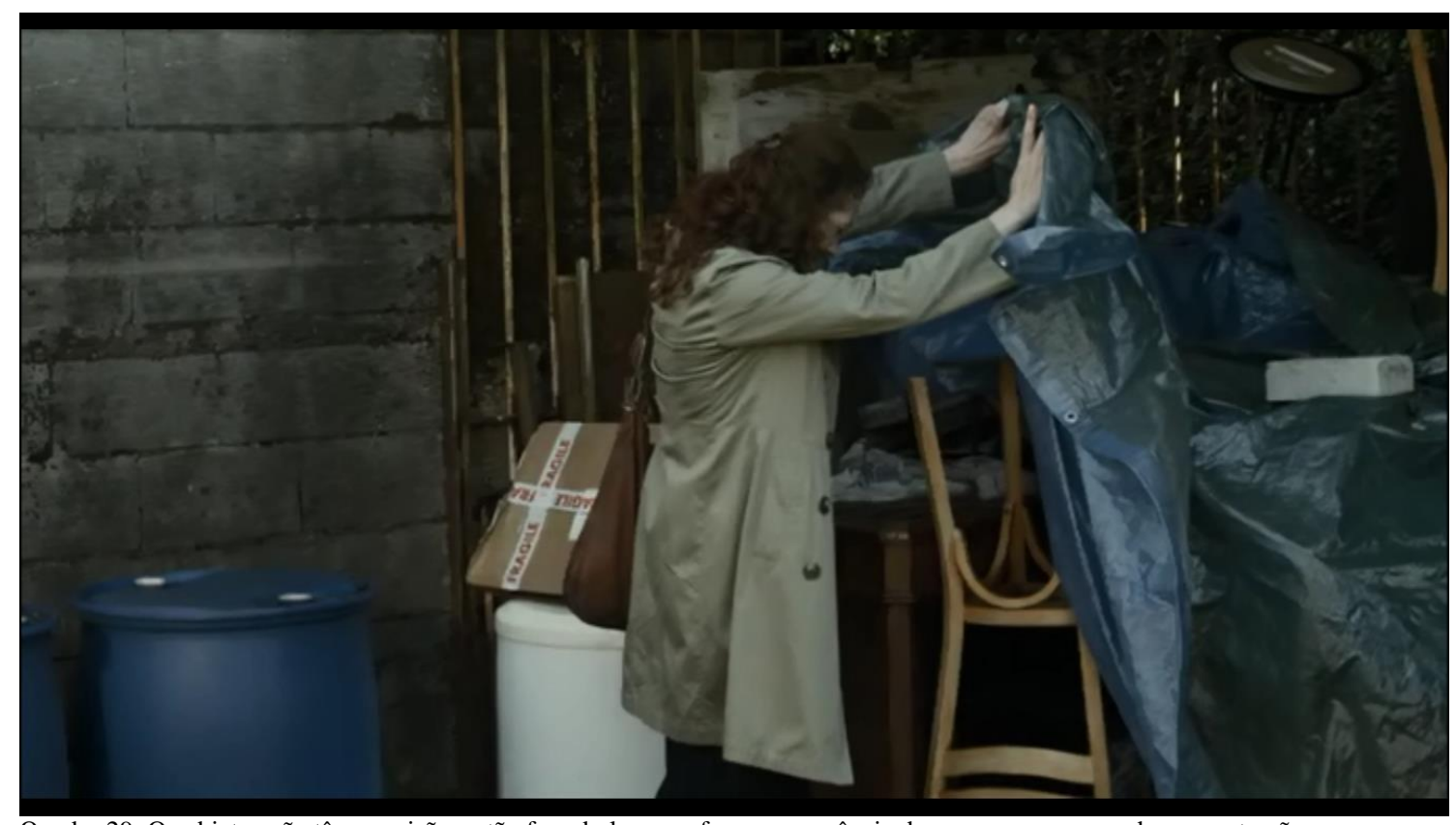

Quadro 29: Os objetos não têm precisão, estão fora do lugar, reforçam a ausência da casa como espaço de concentração. 
Louise guarda suas coisas em depósito alheio, as fotos da família permanecem resguardadas em uma caixa, seus apetrechos mal acomodados em caixotes empilhados. Os pertences da protagonista, como suas práticas cotidianas, estão desterritorializados, isto é, fora do lugar pretendido. Os objetos estão desordenados, espalhados, solicitam a casa como território doméstico, lugar da apropriação, do pertencimento, uma ilusão de estabilidade necessária. Uma foto de mãe e filha no para-sol do carro é como um portaretratos em cima da cômoda do quarto.

É preciso perder a casa para se dar conta de sua precisão: “o desenraizamento é o único apelo que convoca os mortais para um habitar", nos diz Heidegger (ibidem, p.141). Se por um lado, o filme Louise Wimmer traz o carro como lugar reconfigurado em novas funcionalidades e possibilidades expressivas para se pensar modos de habitar da contemporaneidade, por outro o desejo da personagem Louise por uma moradia fixa e segura questiona as mudanças de paradigmas do habitar diante de uma mobilidade exacerbada.

Na última sequência do filme, a mise-en-scène repousa no contraponto entre o dentro e o fora. No interior do bistrôt de Nicole, Louise recebe uma carta da assistente social. Após uma espera de mais de sete meses, sua expressão não demonstra nenhuma expectativa. Um pouco antes, ela mesma havia discursado ao colega Didier que "o importante é acreditar" ${ }^{\prime 76}$. Calmamente, ela sai do recinto, e do lado de fora encontra Didier fumando um cigarro. Na organização interna do plano, um movimento de câmera panorâmico acompanha sua saída desde o interior, vista pela transparência da porta envidraçada, até sua chegada ao lado do amigo. O plano segue com alguma movimentação de pedestres diante da câmera e alguns passos de Louise para fazer da leitura um ato privado.

A próxima imagem enquadra o rosto da protagonista, deixando Didier ao fundo e fora de foco. Eles dividem o mesmo espaço, mas o acontecimento diz respeito apenas a Louise. O enquadramento em primeiro plano deixa claro uma discreta emoção, compreendida apenas no plano seguinte, no escritório da assistente social. A personagem aparece em posição frontal perguntando “onde é o apartamento?”,77. Se ela fala a alguém, nesse plano isto não é visível. O perceptível é seu sorriso em uma mistura de alívio, satisfação e alegria. Uma montagem paralela, em campo e contracampo, se inicia, então,

\footnotetext{
76 "L'important c'est d'y croire". N.T.

77 "Il est où l'appartement". N.T.
} 
mostrando um diálogo entre a "nova moradora" e a assistente descrevendo detalhes do apartamento, em uma cumplicidade evidente.

$\mathrm{Na}$ sequência seguinte, Louise caminha à deriva pela noite. Em passos lentos, atravessa a ponte com calma e sempre sorrindo. Ao fundo, o barulho de carros passando faz parte do universo diegético da cena, mas relembra um momento que já passou. Os ruídos cessam, sobram os passos da moça e a água batendo na construção. Ela se aproxima do guarda-corpo tomado quase como um traço em perspectiva. Na plasticidade da imagem, todos os outros elementos estão desfocados, sobram apenas Louise e fragmento de ponte, agora em plano conjunto. A trilha leva o espectador dessa cena à seguinte: Didier dirige o carro e acompanha Louise em sua mudança. Eles não conversam, apenas cantam e riem. A música é diegética, toca no rádio e é acompanhada por ambos. $\mathrm{O}$ elemento carro se confirma como personagem, serviu de moradia e agora, como veículo de transporte conduz a protagonista a seu novo lar. O carro não é mais fixidez, assume sua função primeira: é automóvel e está em movimento.

O diretor Mennegun constrói a cena na expressão de cosmopolitas "aspirantes a residentes". Os edifícios do bairro onde Louise irá habitar são filmados sob a perspectiva do veículo que se movimenta. O ângulo contra plongée no enquadramento das habitações reforça o ponto de vista da personagem, ela olha para eles e sorri o tempo todo. No vidro frontal do carro, o reflexo dos edifícios em deslocamento se funde à imagem de Louise, fazendo a interseção entre espaço e personagem. Em montagem alternada em campo e contracampo, os planos não enquadram possíveis moradores, apenas protagonista, árvores e prédios. Não há dúvidas, essa narrativa é a trajetória de Louise. No último plano do filme, o rosto de Louise ocupa a dimensão esquerda do quadro. Em profundidade, acompanha-se o movimento do veículo. Seu rosto agora é superfície, se abre diante da luminosidade solar que invade o quadro. Ela fecha os olhos e sorri. A expressão facial anuncia sua chegada ao destino final. 


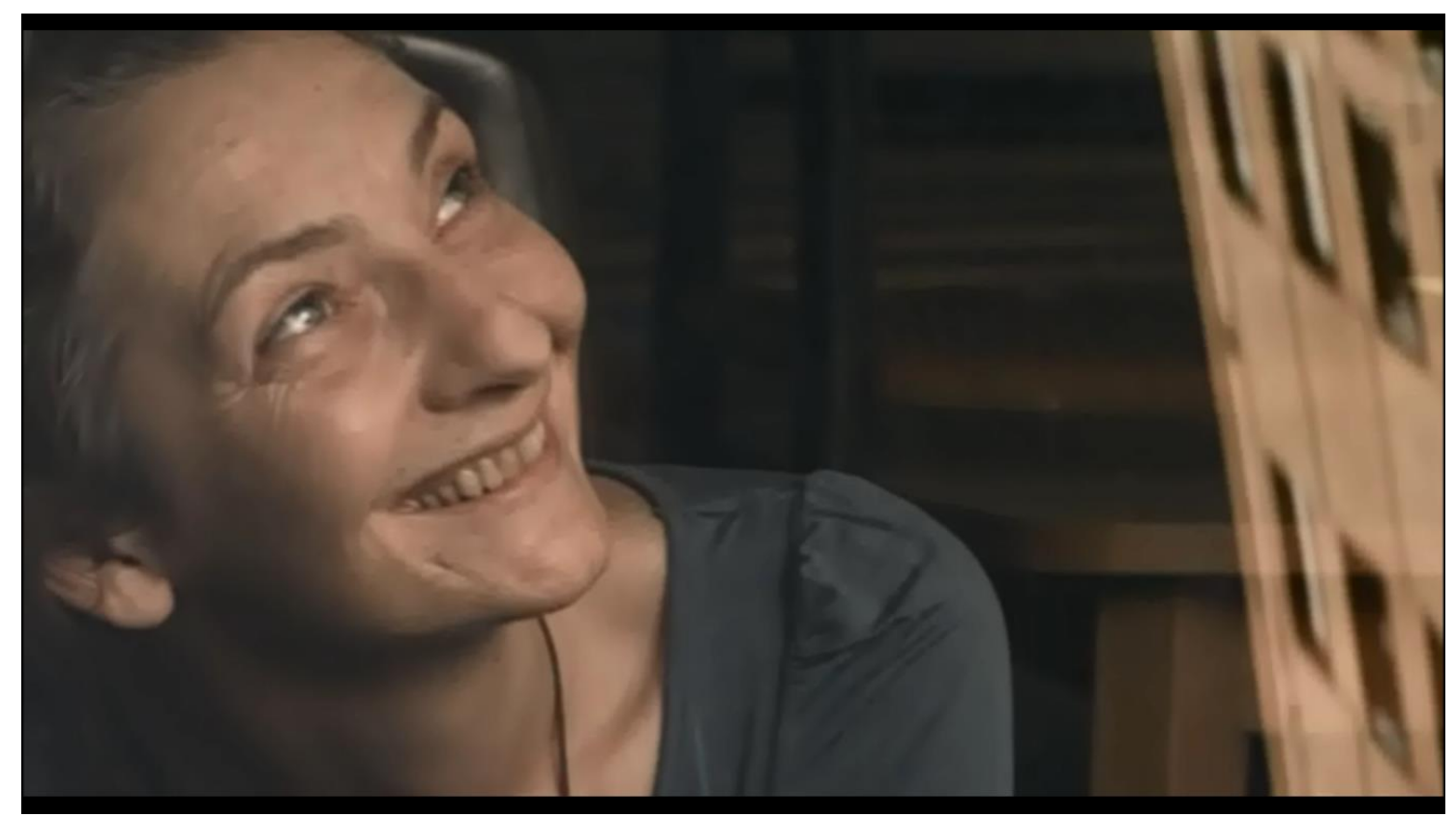

Quadro 30: Após um percurso sem referências, a protagonista retoma a casa como espaço propício à vida íntima e protegida. 


\section{Considerações Finais}

Diante das experiências de mobilidade e da dinâmica da globalização, buscamos neste trabalho investigar a reconfiguração de modos de habitar representados em narrativas de ficção do cinema mundial recente. Para tanto, investiu-se em filmes que evidenciaram um novo modelo narrativo do gênero cotidiano, deslocando a figura do "homem comum" como protagonista para "homem cosmopolita", inserido em estados de transitoriedade. Ao mesmo tempo, as narrativas de desenraizamento e despertencimento apontaram para um imaginário que questiona a casa como espaço fixo e seguro, bem como a funcionalidade dos lugares e a localização de práticas cotidianas.

Além do diálogo com o gênero cotidiano, procuramos conceber modos de habitar próximos a percursos de espaço, vinculando personagens e lugares. Para pensar o vínculo, um caminho interdisciplinar traçou convergências nos estudos fenomenológicos na tentativa de engajar as materialidades fílmicas ao que os lugares têm de concretude e abstração. Para tanto, reconhecemos na cinematografia pesquisada, inúmeras formas de se habitar o espaço urbano: habitar uma casa, habitar com o outro, habitar em trânsito, habitar em hotéis, habitar na rua. O filme é um nodo de demarcações e deslocamentos, enquanto o espaço fictício, um lugar abstrato construído em imagens e sons e evocado na imaginação. Dos inúmeros modos de habitar apreendidos, este trabalho analisou três deles. Compreendemos que cada filme oferece uma trajetória singular e uma topografia fílmica própria, contudo admite-se um diálogo com modos de habitar análogos explorados em outras narrativas do cinema mundial. Ao considerarmos essa possibilidade, os filmes apresentam-se em um contexto de imaginário coletivo que aponta para obras audiovisuais com potencial expressivo diante das problemáticas do mundo urbano.

O primeiro filme, Um conto chinês (Un cuento chino de Sebastián Borensztein), expôs o habitar em seu sentido mais tradicional: a casa como morada interpenetrada pela ideia de fixidez, habitação localizada e enraizada no solo que nos reconforta com a imagem de espaço de acolhimento, lugar protegido onde repousa o que nos é íntimo e conhecido. Habitar, residir, morar nos sugere uma associação costumeira: a "casa" como sinônimo de residência ou moradia. A permanência do homem no mundo passa pela noção da casa como espaço protegido, enquanto a segurança no espaço de dentro é apenas uma ilusão. Esse imaginário é explorado na intenção de resgatar o espaço como elemento ativo e fator essencial de coerência e estratégia narrativa. Se fez necessário, então, dar à 
narrativa uma dose de conflito, oferecer à morada fixa certa transitoriedade, abrindo a casa para o que é desconhecido. O espaço doméstico, nesse filme e em tantos outros, acaba invadido, isto é, compartilhada com desconhecidos, possuída por olhares estranhos, partilhada entre diferentes.

O modo de habitar evidenciado em Um conto chinês dialoga com filmes como A casa vazia do coreano Kim Ki-Duk (2004), Caché de Michael Haneke (2005), Invasão de domicílio de Anthony Minghella (2006), O homem ao lado dos argentinos Cohn e Duprat (2009), e Dentro da casa do francês François Ozon (2012), que exploram o tema da invasão de privacidade a partir do espaço da casa; com os Benvindo de Philippe Lioret (2009) e $O$ porto de Aki Kaurismäki (2011), onde a casa se oferece como um espaço de compartilhamento para personagens de diferentes nacionalidades; e também em Através da janela de Tata Amaral (2000), Home de Ursula Meier (2008), Os inquilinos de Sérgio Bianchi (2010), O som ao redor de Kleber Mendonça Filho (2012), que vão permear a casa pela dinâmica urbana vivida no espaço público externo. O espaço doméstico nesses filmes é uma morada vazada, destroçada pelo que vem de fora, lugar agenciado pela noção de fronteira, por experiências de alteridade, entrelaçado entre o exterior e o interior, entre o privado e o público, entre o familiar e o desconhecido.

As instabilidades cotidianas nesses filmes são reveladas como consequências da insegurança e do individualismo presente na sociedade urbana e acabam deslocando a casa de seu lugar seguro, onde o mundo pessoal do protagonista se vê confrontado pela presença de outros personagens. Suas temáticas exploram a violência no espaço doméstico, as confusões entre vizinhos e os dramas na intimidade familiar, concebendo modos de habitar fundados a partir da relação entre personagens antagônicos: são casas invadidas por estranhos, casas compartilhadas com imigrantes e estrangeiros, casas tomadas pelas intempéries da vida urbana.

O segundo filme, Encontros e desencontros (Lost in translation) de Sofia Coppola), se inclui em narrativas cinematográficas que expõem homens em deslocamento e espaços de trânsito como modos de habitar a cidade, sejam os lugares de tráfego que assumem provisoriamente a função de "casa" como o aeroporto no filme Terminal de Steven Spielberg (2004), o posto de gasolina em O homem mau dorme bem de Geraldo Moraes (2008), ou mesmo o supermercado no filme Onde mora o coração de Matt Williams (2000); sejam os espaços-ligação de Café Lumière de Hou Hsiao-hsien (2004) e Na cidade de Silvia de José Luis Guerín (2008); sejam os hotéis dos filmes A Menina santa de Lucrecia Martel (2003), Meu mundo em perigo de José Eduardo Belmonte 
(2007), Management de Stephen Belber (2009), Um lugar qualquer (2010) de Sofia Coppola, Amor sem escalas de Jason Reitman (2010) ou Natimorto de Paulo Machline (2011).

Poderíamos ter conceituado esses espaços de não-lugares, termo utilizado pelo antropólogo Marc Augé em contraposição ao lugar antropológico que se define como identitário, relacional e histórico. Nas grandes cidades, há uma espécie de proliferação de não-lugares definidos como "espaços da circulação, da distribuição e da comunicação, específicos da época contemporânea" (AUGÉ, 1994, p.134), que tendem a apresentar características de espaços de passagem, e não de convivência. No entanto, o cinema de ficção reinventa novas referências espaciais para dar conta das mobilidades da contemporaneidade. Investindo-os de valores narrativos, simbólicos, afetivos, essas narrativas tomaram para si a transitoriedade de não-lugares e a converteram em convivialidade, concebendo-os como pontos de interseção onde o encontro com o outro se torna possível. A designação de "espaços de trânsito" nos pareceu mais apropriada pois reconhece, ao mesmo tempo, uma dinâmica de mobilidade e o cruzamento de sujeitos identificados com a transitoriedade local.

Se nas primeiras narrativas, a casa como morada fixa aparece permeada por personagens que vêm de fora, aqui os espaços de trânsito se fecham para um sentido de interioridade. Em seus desejos de permanência, os personagens vedam a permeabilidade desses ambientes demarcando esses espaços como lugares seus. Alojados provisoriamente em hotéis, portos, aeroportos, estações rodoviárias ou em fluxo contínuo de idas e vindas entre espaços-ligação como vias férreas e avenidas, os protagonistascosmopolitas apreendem esses lugares de mobilidade e os transmutam em espaços de permanência como arrivistas. Para se sentirem abrigados, deixam suas marcas por onde passam. A casa para eles é somente ponto de chegada, mas uma chegada pulsante de novas partidas.

Agenciados pelo que é passageiro, os espaços de trânsito investigados relatam práticas cotidianas que se aproximam de sua natureza de deslocamento. Em hotéis, aeroportos, rodoviárias há sempre quem chega e também alguém que parte. A missão corriqueira dessas "edificações" é dar conta destes percursos em contínuo movimento, abrigos temporários à beira de rodovias, em grandes avenidas, em espaços limiares da cidade, são modos de habitar urbanos permeados por inconstâncias e transitoriedade. Entretanto, os personagens percebidos como arrivistas dão a esses lugares um sentido de 
residência, sentem necessidade de segurança e demarcam seus espaços em uma permanência temporária.

As arquiteturas urbanas pesquisadas nessas narrativas são reconhecidas como impessoais e transitórias, estão delimitadas pelas ações dos personagens, apreendidas na permanência de movimentações e fluidez, na demora entre uma chegada e uma partida, implicando na construção de novas espacialidades. Deste modo, o cinema de ficção mundial se abre para o que esses espaços oferecem de sensibilidades e possibilidades imaginativas, preferindo encará-los como a expressão de cosmopolitas "aspirantes a residentes" orientados em um fluxo ininterrupto (estagnado) da efêmera vida cotidiana. Suas histórias cotidianas fixam ações fugidias e fazem dos hotéis e dos locais de tráfego cenários diferenciados, em contraponto ao imaginário de uma vida enraizada e resguardada.

Dentre os espaços de trânsito pesquisados, o hotel apareceu como lugar bastante explorado em narrativas ficcionais do cinema mundial da última década. Hotéis são edificações de fluxo inseridas em uma eterna mobilidade, inconstância que dificulta a noção de próprio, de doméstico, presente na maioria das moradias. Em uma representação estereotipada, são espaços de turistas, de personagens que se deslocam a passeio ou a trabalho por um período determinado, um ponto de orientação e identificação que se contrapõe ao lugar "casa". Todavia, alguns filmes apresentaram personagens em estados transitórios com certa fixidez, instaurando-os em hotéis em uma concepção de habitar semelhante ao espaço da casa. Nesses lugares, os "hóspedes" se sentem tão à vontade quanto em "sua própria casa". A intenção de seus autores é oferecer novas visibilidades e funcionalidades a este lugar aparentemente manifesto em experiências de circulação e de tráfego. Enquanto a fidelidade a uma noção de "casa" como espaço estável e seguro não parece mais tão certo, os novos modelos do gênero cotidiano contemplam o hotel não apenas como espaço turístico, mas em um modo para se experienciar as transitoriedades da vida urbana replicadas pelos, ainda vivos, desejos de pertencimento.

Se nos filmes anteriores reconhecemos personagens imigrantes e nômades que se deslocam o tempo todo, no terceiro filme analisado, Louise Wimmer de Cyril Mennegun, a figura do protagonista é um cosmopolita "desorientado". Transformar, adaptar, improvisar, são as práticas de espaço de personagens que se encontram fora do lugar, sujeitos desnorteados, alojados em locais provisórios, em espaços precários. A moradia provisória da protagonista, um carro, se assemelha aos locais improvisados que servem como residência para personagens desamparados ou à margem da sociedade em 
outros filmes como Dois perdidos numa noite suja do brasileiro José Joffily (2002), Eu não quero dormir sozinho de Tsai Ming-Liang (2006), Pronto para recomeçar de Dan Rusch (2011), Elefante branco de Pablo Trapero (2012), Indomável sonhadora do americano Benh Zeitin (2012), e Cães errantes do diretor malaio Ming-Liang Tsai (2013). O sentido de transitório em uma narrativa pode estar no movimento de um personagem que se desloca ou em espaços de trânsito agenciados por práticas de mobilidades, porém, nesses filmes, o transitório se define como algo que assume provisoriamente o lugar de outro. Assim, um carro, um jardim, uma rua, um local abandonado, assumem provisoriamente o lugar da casa.

As narrativas do gênero do cotidiano abrangem modos de habitar repletos de transitoriedades apoiados no deslocamento de personagens cosmopolitas, imigrantes, "arrivistas", mas reconhecem, ao mesmo tempo, o estado precário em que vivem as populações marginalizadas pela urbanização desenfreada e pela dinâmica da globalização da contemporaneidade. Suas temáticas exploram as incertezas da vida urbana, enquanto seus personagens são indivíduos sem casa para habitar, desabrigados ou mal acomodados em lugares adaptados. $\mathrm{O}$ cotidiano se apresenta na trivialidade de um dia-a-dia, entre o espaço doméstico e o trabalho, nos pequenos acontecimentos diários, mas nesses filmes, se reconhece em contextos de debilidade, de ausência, de sobrevivência.

A casa é o espaço de pertencimento e de orientação, um homem sem casa é necessariamente um sujeito disperso. Ela segue como um ponto de partida e também um ponto de chegada, um lugar de concentração de boa parte das ações triviais de "homens comuns". Por outro lado, a falta da casa como espaço de abrigo instaura o personagem em um estado de incertezas. Sem a casa, os protagonistas aparecem como seres desorientados, espalhando suas práticas diárias em espaços alheios, em trânsito, em locais públicos.

Os filmes que abordam temáticas como a desigualdade social e o desemprego posicionam seus personagens em instâncias narrativas de precariedade, de tal modo que inseri-los em lugares provisórios, desabriga-los é fundamentar um sentido de despertencimento em modos de habitar o espaço urbano. Seus personagens parecem à deriva, entregues ao acaso, são seres dispersos. Estão abandonados em algum canto do mundo, em um espaço intervalar. A noção de pertencimento conduz ao ser-no-mundo de Martin Heidegger, a um "se sentir em casa". Como Louise, os protagonistas desses filmes não se sentem em casa onde estão. A casa aqui toma um sentido de concretude ao inverso: 
em sua ausência, há que perceber sua existência como espaço marcado pelo sentido de resguardo e proteção.

Dos modos de habitar apreendidos nos filmes Um conto chinês, Encontros $e$ desencontros, e Louise Wimmer, e seus possíveis diálogos com outras narrativas cinematográficas, indica-se um caminho para analisar (ou mesmo criar) "casas" em narrativas ficcionais, apontando para quatro categorias analíticas: a relação estabelecida entre o personagem e sua morada, buscando reconhecer um modo próprio e diferenciado de experienciar o espaço doméstico; os agenciamentos instituídos entre o espaço interior e o exterior, o dentro e o fora da morada; os fragmentos arquitetônicos tomados enquanto detalhes narrativos; a apropriação dos ambientes e objetos domésticos pelos personagens.

Diante do panorama apresentado, as referências de modos de habitar investigadas nesta tese tematizam experiências urbanas, proporcionando uma contribuição no entendimento da relação entre espaço, sujeito e mobilidade. $\mathrm{O}$ fato do cinema se interessar em desvendar modos de habitar o espaço urbano reafirma nosso posicionamento como homens da contemporaneidade. Esses filmes apontam para um imaginário do cosmopolita como um ser desenraizado, sem pertencimento, em trânsito constante, apropriando-se de seu entorno de modo transitório. Ao mesmo tempo, os espaços narrativos para localizar e identificar "homens comuns" sofrem mutações diante da dinâmica urbana, e decifra-los passa necessariamente por uma interpretação de suas moradas. As hipóteses levantadas implicaram na investigação desses questionamentos e em sua fundamentação, o que resultou nas seguintes evidências:

* As narrativas cotidianas do cinema mundial contemporâneo convidam à interiorização, privilegiando personagens a cidades. Ainda que as cidades apareçam como elemento narrativo relevante e não apenas como cenário, os filmes de ficção oferecem pontos de vista diferenciados do espaço urbano, levando em conta sua relação com os protagonistas.

* Em grande parte dos filmes elencados, os ambientes domésticos são os locais da família e do indivíduo, reconhecidos como espaços íntimos. Contudo, habitações, casas e quartos se mostram permeados por exterioridades, sujeitos a invasões e abertos a visibilidades do mundo de fora.

* A polaridade dentro-fora, interior-exterior, casa-rua é constantemente questionada em modos de habitar transitórios, apreendida pela noção de fronteira, ponte, interseção, entre outros espaços de ligação. 
* Personagens cosmopolitas alteram usos e funções costumeiras de objetos, lugares e práticas, provocando uma rearticulação dos espaços narrativos: o quarto não serve para dormir, o carro não é transporte, o hotel é residência e a casa é indagada como espaço seguro e abrigado.

Os modos de habitar se manifestam enquanto possibilidades narrativas, levando em conta temáticas urbanas com referências ao mundo contemporâneo e a sua transitoriedade. Filmes do cinema mundial revisitam o gênero do cotidiano porque trazem espaços diferenciados para habitar, que não se pautam apenas em uma casa fixa. A mobilidade espacial deixa de ser exclusividade de filmes road movies para fazer parte dos espaços domésticos. O lugar do deslocamento não é somente a estrada, mas as habitações, sejam os espaços de trânsito que assumem o papel de morada, sejam as casas que se transmutam em espaços-ligação. A mobilidade de protagonistas-cosmopolitas fundamenta uma ampliação para o conceito casa, sugerindo experiências transitórias para se pensar novos modos de habitar. Ao se posicionar diante de um homem e de um espaço que não cessa de se modificar, o cinema articula experiência vivida e percebida, amparando a apreensão do universo que nos cerca, entrevendo a organização de nossas dinâmicas espaciais e sua influência nos imaginários da contemporaneidade.

Se encontramos singularidades para narrar um hotel, um carro, uma casa, se somos tomados pela transitoriedade evidente na reconfiguração desses lugares apreendidos não mais como cenário, mas como elemento fundante de narrativas cinematográficas, talvez seja porque, ao trafegar em ambientes domésticos do nosso dia-a-dia, sentimos que as coisas e os lugares, vistos de perto, são muito mais do que concretudes; flexibilizam tudo que há de certeza e de fixidez na vida cotidiana, consistem em motivações para novos usos e apropriações, se oferecem com toda diversidade em pontos de observação, e por fim, são transformações e sensibilidades para pôr em movimento um mundo banal e ilusoriamente enraizado. 


\section{Referências Bibliográficas}

AGAMBEN, Giorgio. O que é contemporâneo e outros ensaios. Chapecó: Argos, 2010. AGEL, Henri. L'espace cinematographique. Paris: Éditions Universitaires, 1978.

ANDREW, James Dudley. As principais teorias do cinema: uma introdução. Rio de Janeiro: Zahar, 2002.

ARAUJO, Rosane Azevedo de. A cidade sou eu: o urbanismo do século XXI. 2007. Tese (Doutorado em Arquitetura e Urbanismo) - Rio de Janeiro: Universidade Federal do Rio de Janeiro, Faculdade de Arquitetura e Urbanismo, 2007.

ARENDT, Hannah. A condição humana. Rio de Janeiro: Forense Universitária, 1993.

ARISTÓTELES. Arte Poética. São Paulo: Editora Martin Claret Ltda, 2003.

ARRIGUCCI JR., Davi. Enigma e comentário: ensaio sobre literatura e experiência. São Paulo: Companhia das Letras, 1987.

ARNAUD, Diane. Diegese. In: BAECQUE, Antoine de; CHEVALLIER, Philippe (Orgs.). Dictionnaire de la pensée du cinema. Paris, Quadrige/Puf, 2012.

AUGÉ, Marc. O sentido dos outros: atualidade da Antropologia. Petrópolis: Vozes, 1999. Papirus, 1994.

Não-lugares: introdução a uma antropologia da supermodernidade. Campinas:

AUMONT, Jacques. O cinema e a encenação. Lisboa: Texto e Grafia, 2008.

As teorias dos cineastas. Campinas: Papirus, 2004.

O olho interminável: cinema e pintura. São Paulo: Cosac Naify, 2004.

; MARIE, Michel. A análise do filme. Lisboa: Texto \& Gráfica, 2009.

Dicionário técnico e crítico de cinema. Campinas: Papirus, 2003.

AUMONT, Jacques et al. A estética do filme. São Paulo: Papirus, 2012.

BACHELARD, Gaston. O ar e os sonhos. São Paulo: Martins Fontes, 2001.

.A poética do espaço. São Paulo: Martins Fontes, 1993.

BAUMAN, Zygmunt. Vida em fragmento: sobre ética pós-moderna. Rio de Janeiro: Zahar, 2011.

. Modernidade líquida. Rio de Janeiro: Jorge Zahar, 2001. 1999.

. Globalização: as consequências humanas. Rio de Janeiro: Jorge Zahar Editor,

O mal-estar da pós-modernidade. Rio de Janeiro: Jorge Zahar, 1998.

BHABHA, Homi K. O local da cultura. Ed. UFMG: Belo Horizonte, 2005.

BAKHTIN, Mikhail. Os gêneros do discurso. In: Estética da criação verbal.

São Paulo: Martins Fontes, 1997. pp.277-326.

BAPTISTA, Mauro; MASCARELlO, Fernando (Orgs.). Cinema Mundial Contemporâneo. Campinas: Papirus, 2008. 
BARTHES, Roland. O grau zero da escrita. São Paulo: Martins Fontes, 2004.

.A câmara clara: nota sobre a fotografia. Rio de Janeiro: Editora Nova Fronteira, 1984.

O efeito do real. In: BARTHES, Roland et al. Literatura e semiologia. Petrópolis: Vozes, 1972. pp.35-44.

BARTHES, Roland et al. Análise estrutural da narrativa. Rio de janeiro: Editora Vozes Ltda, 2011.

BAUDRILLARD, Jean. O sistema dos objetos. São Paulo: Perspectiva, 1997.

Simulacros e simulação. Lisboa: Relógio d'Água, 1991.

BAUER, Martin W.; GASKELL, G. Pesquisa qualitativa com texto, imagem e som: um manual prático. Petrópolis: Vozes, 2002.

BAZIN, André. Orson Welles. Rio de Janeiro: Jorge Zahar, 2005.

O cinema: ensaios. São Paulo: Brasiliense, 1991.

BELLOUR, Raymond. Entre-imagens. Campinas: Papirus, 1997.

BENJAMIN, Walter. A obra de arte na era de sua reprodutibilidade técnica. In:

Magia e técnica, arte e política: ensaios sobre literatura e história da cultura. (Obras escolhidas vol.1). São Paulo: Brasiliense, 1994. pp. 165-196.

BERGFELDER, Tim; HARRIS, Sue; STREET, Sarah. Film architecture and the transnational imagination: set design in 1930s European cinema. Amsterdam: Amsterdan University Press, 2007.

BETTON, Gérard. Estética do cinema. São Paulo: Martins Fontes, 1987.

BLANCHOT, Maurice. O livro por vir. São Paulo: Martins Fontes, 2005.

BOGÉA, Marta. Cidade errante: arquitetura em movimento. São Paulo: Editora Senac, 2009.

BORDWELL, David. La narración en el cine de ficción. Barcelona: Ediciones Paidós Ibérica, 1985.

La narración en el cine de ficción. Espanha: Paidós, 1996.

BOTTON, Alain. A arte de viajar. Rio de Janeiro: Intrínseca, 2012.

BRANDÃO, Ludmila de Lima. Espaço e nomadismo em La mesure du monde. In: FERREIRA, Jerusa Pires (Org.). Oralidade em tempo e espaço. São Paulo: Fapesp, 1999. pp. 107-115.

- A casa subjetiva: matérias, afectos e espaços domésticos. São Paulo: Perspectiva, 2002.

BRESSON, Robert. Notes sur le cinématographe. Paris: Gallimard, 1988.

BRUNO, Giuliana. Atlas of emotion: journeys in art, architecture, and film. New York: Verso, 2002.

BURCH, Noel. Práxis do cinema. São Paulo: Perspectiva, 1992.

CANCLINI, Néstor García. A globalização imaginada. São Paulo: Iluminuras, 2007.

Culturas Híbridas. São Paulo: Editora da Universidade de São Paulo, 2000. 
CALVINO, Ítalo. As cidades invisíveis. São Paulo: Companhia das Letras, 1990b.

CAUQUELIN, Anne. A invenção da paisagem. São Paulo: Martins, 2007.

CAVALCANTI, Lauro; GUIMARAENS, Dinah. Morar - a casa brasileira. Rio de Janeiro: Avenir Editora, 1984.

CAVALCANTE, Denise. Imagens do cotidiano no cinema brasileiro: olhar sobre a casa. Dissertação (Mestrado em Comunicação). Brasília: Universidade de Brasília/Faculdade de Comunicação, 2005.

O sublime no cotidiano: análise do filme As coisas simples da vida, de Edward Yang. In: MONTORO, Tânia; CALDAS, Ricardo. (Org.). De olho na imagem. Brasília: Fundação Astrojildo Pereira, Editoral Abaré, 2006. pp. 35-46.

CAVELL, Stanley. À la recherche du bonheur: Hollywood et la comédie du remariage. Paris: Cahiers du Cinéma, 1993.

El cine, puede hacernos mejores?. Madrid: Katz, 2008.

CARRIÈRE, Jean Claude. A linguagem secreta do cinema. Rio de Janeiro: Nova Fronteira, 1995.

CERTEAU, Michel de. A invenção do cotidiano: artes de fazer. Petrópolis: Editora Vozes, 2009.

A invenção do cotidiano: morar, cozinhar. Petrópolis: Editora Vozes, 1997.

CHARNEY, Leo; SCHWARTZ, Vanessa R. (Orgs.). O cinema e a invenção da vida moderna. São Paulo: Cosac Naify, 2001.

CHAUVIN, Serge. Fiction. In: BAECQUE, Antoine de; CHEVALLIER, Philippe (Orgs.). Dictionnaire de la pensée du cinema. Paris, Quadrige/Puf, 2012. pp. 297-300.

CHEVAlLIER, Philippe. Espace. In: BAECQUE, Antoine de; CHEVALLIER, Philippe (Orgs.). Dictionnaire de la pensée du cinema. Paris, Quadrige/Puf, 2012. pp.277-281.

CHION, Michel. A audiovisão: som e imagem no cinema. Lisboa: Edições Texto \& Grafia, 2011.

Le son au cinema. Paris: Cahiers du Cinéma, Editions de l'Etoile, 1985.

COHEN, Margaret. A literatura panorâmica e a invenção dos gêneros cotidianos. In: CHARNEY, Leo; SCHWARTZ, Vanessa R. (Orgs.). O cinema e a invenção da vida moderna. São Paulo: Cosac Naify, 2001. pp. 315-351.

DAMATTA, Roberto. A casa e a rua: espaço, cidadania, mulher e morte no Brasil. São Paulo: Editora Brasiliense, 1994.

DARDEL, Eric. L'homme et la terre. Paris: PUF, 1952.

DELEUZE, Gilles. A imagem-tempo. São Paulo: Brasiliense, 2007.

Conversações. Rio de Janeiro: Ed. 34, 1992.

. Cinema: a imagem-movimento. São Paulo: Brasiliense,1985.

; GUATARRI, Félix. O que é a filosofia? Rio de Janeiro: Ed. 34, 1996.

1995.

Mil platôs: capitalismo e esquizofrenia, vol.1. Rio de Janeiro, Ed. 34, 
DERRIDA, Jacques. Uma arquitetura onde o desejo possa morar: entrevista de Jacques Derrida a Eva Meyer. In: NESBITT, Kate (Org.). Uma nova agenda para a arquitetura: antologia teórica (1965-1995). São Paulo: Cosac Naify, 2006.

DURAND, Gilbert. As estruturas antropológicas do imaginário. São Paulo: Martins Fontes, 1997.

DIAS, Karina. Entre visão e invisão: paisagem [por uma experiência da paisagem no cotidiano]. Brasília: Programa de Pós-graduação em Arte, Universidade de Brasília, 2010.

DUFRENNE, Mikel. Estética e filosofia. São Paulo: Perspectiva, 1972.

EICHEMBERG, André Teruya; BARBIERI, Maria Júlia. Espaço e cotidiano: fluxos, redes, freqüências. Vitruvius, 2004. Disponível em

<http://www.vitruvius.com.br/revistas/read/arquitextos/05.050/567> Acesso em: 09 dez 2011.

FABRIS, Mariarosaria. Neorrealismo italiano. In: MASCARELLO, Fernando. História do cinema mundial. Campinas: Papirus, 2012.

FRASCARI, Marco. O detalhe narrativo. In: NESBITT, Kate (Org.). Uma nova agenda para a arquitetura: antologia teórica (1965-1995). São Paulo: Cosac Naify, 2006. pp. 538 a 555.

FERRARA, Lucrecia D’Aléssio. Design em espaços. São Paulo: Edições Rosari, 2002.

FERREIRA, Ângela; MARQUES, Sônia. Privado e público: inovação espacial ou social. Scripta Nova - Revista Electrônica de Geografia y Ciências Sociales. Disponível em: < http://www.ub.es/geocrit/sn-69-20.htm>. Acesso em: 10 mai 2011.

FRANÇA, Andréa. Terras e fronteiras no cinema político contemporâneo. Rio de Janeiro: 7Letras, 2003.

; LOPES, Denilson (Orgs.). Cinema, globalização, interculturalidade. Chapecó: Argos, 2010.

GARDIES, André. Le Récit filmique. Paris: Hachette Livre, 1993a.

L'espace au cinéma. Paris: Méridiens Klincksieck, 1993b.

Architecture, décor et cinéma. Paris: Corlet - Télérama, no 75, 1995. pp 03-07.

GASKELL, George. Pesquisa qualitativa com texto, imagem e som: um manual prático. Petrópolis: Vozes, 2002.

GAUDREAULT, André, e JOST, François. A narrativa cinematográfica. Brasília: Editora Universidade de Brasília, 2009.

GIDDENS, Anthony. Modernidade e identidade. Rio de Janeiro: Zahar, 2002.

. As consequências da modernidade. São Paulo: UNESP, 1991.

GREGOTTI, Vittorio. Território e arquitetura. In: NESBITT, Kate (Org.). Uma nova agenda para a arquitetura: antologia teórica 1965-1995. São Paulo: Cosac Naify, 2006.

GUIMARÃES, César. O retorno do homem ordinário do cinema. Contemporânea, Salvador, v. 3, n. 2, 2005. pp. 71-88. Disponível em:

$<\underline{\text { http://www.portalseer.ufba.br/index.php/contemporaneaposcom/article/viewArticle/34 }}$ 5 >. Acesso em: 10 abr 2014.

$\overline{\mathrm{UFMG}}, 2007$.

et al. (Org.). O comum e a experiência da linguagem. Belo Horizonte: Editora 
GUNNING, Tom. Éric Rohmer et l'héritage du réalisme cinématographique. Presses universitaires de Rennes, 2007. Disponível em: $<$ http://books.openedition.org/pur/641 $>$. Acesso em: 21 out 2013.

GODARD, Jean-Luc. La paroisse morte. Disponível em: $<$ http://claricehadalittlelamb.tumblr.com/post/27907949403/la-paroisse-morte $>$. Acesso em: 15 set 2013 .

GOSCIOLA, Vicente. A conceituação de deslocografia para o cinema de migrações. Revista Comunicación, N.10, Vol.1, 2012. pp.363-370. Disponível em: $<$ http://www.revistacomunicacion.org/pdf/n10/mesa2/029. $>$. Acesso em: 06 abr 2013.

; MAGNO, Maria Ignês Carlos. A construção do imaginário em deslocamento: um estudo da deslocografia no sertão do cinema brasileiro. Cine Brasileño. N.76, 2011. Disponível em:

$<$ http://www.razonypalabra.org.mx/N/N76/monotematico/02_Carlos_M76.pdf. $>$.

Acesso em: 06 abr 2013.

HABERMAS, Jürgen. Mudança estrutural da esfera pública. Rio de Janeiro: Tempo Brasileiro, 1984.

HALL, Stuart. A identidade cultural na pós-modernidade. Rio de Janeiro: DP\&A, 2000.

HARVEY, David. A condição pós-moderna. São Paulo: Edições Loyola, 1992.

HEIDEGGER, Martin. Introdução à filosofia. São Paulo: Martins fontes, 2009.

- Ensaios e conferências. Petrópolis: Vozes; Bragança Paulista: Editora Universitária São Francisco. 2008.

Ser e tempo, parte I. Petrópolis: Vozes; Bragança Paulista: Editora Universitária São Francisco, 2005a.

. Ser e tempo, parte II. Petrópolis: Vozes; Bragança Paulista: Editora Universitária São Francisco, 2005b.

HELLER, Agnes. O cotidiano e a história, São Paulo: Editora Paz e Terra S/A, 1970.

HOLANDA, Frederico de. (Org.). Arquitetura \& urbanidade. São Paulo: ProEditores, 2003.

O espaço de exceção. Brasília: Universidade de Brasília, 2002.

HUSSERL, Edmund. A ideia da Fenomenologia. Lisboa: Edições 70, 1990.

LAURENTIZ, Paulo. A holarquia do pensamento artístico. Campinas: Edunicamp, 1991.

LEDOUX, Claude-Nicolas. A imagem como filosofia. In: MANGUEL, Alberto (Org.). Lendo imagens: uma história de amor e ódio. São Paulo: Companhia das Letras, 2001. pp. 251-268. LEDOUX,

LEFEBVRE, Henri. La production de l' espace. Paris, Anthropos, 2000.

A vida cotidiana no mundo moderno. São Paulo: Ática, 1991.

A revolução urbana. Belo Horizonte: Editora UFMG, 1999.

LOPARIC, Zeljko. Heidegger. Rio de Janeiro: Jorge Zahar, 2004. 
LOPES, Denilson. No coração do mundo: paisagens transculturais. Rio de Janeiro: Rocco, 2012.

A Delicadeza: estética, experiência e paisagens. Brasília: Editora da

Universidade de Brasília, 2007.

. (Org.). O cinema dos anos 90. Chapecó: Argos, 2005.

LOPES, Paulo Roberto M. A linguagem como forma de habitar: o próximo e o distante. Revista da Associação Nacional dos Programas de Pós-Graduação. Disponível em $<$ http://www.compos.org.br/seer/index.php/e-compos/article/viewFile/255/276 $>$. Acesso em: 15 out 2013 .

LUCAS, Meize R. de Lucena. Imagens do moderno: o olhar de Jacques Tati. São Paulo: Annablume, 1998.

LYNCH, Kevin. A imagem da cidade. São Paulo: Martins Fontes, 1997.

MACHADO, Arlindo. Pré-cinema e pós-cinema. Campinas, SP: Papirus, 1997.

MACIEL, Kátia (Org). Transcinema. Rio de Janeiro: Contra Capa, 2009.

- Transcinema e a estética da interrupção. In: FATORELLI, Antônio (Org.)

Limiares da imagem: tecnologia e estética na cultura contemporânea. Rio de Janeiro: Mauad X, 2006.

MAFFESOLI, Michel. Sobre o nomadismo: vagabundagens pós-modernas. São Paulo: Record, 2001.

.O conhecimento comum. São Paulo, Brasiliense, 1988.

MAGNY, Joël. Histoire des théories du cinéma. Condé-sur-Noireau: CinémActionCorlet Télérama, 1991.

MANGUEL, Alberto (Org.). Lendo imagens: uma história de amor e ódio. São Paulo, Companhia das Letras, 2001.

MARGATO, Izabel (Ed.). Espécies de espaço: territorialidade, literatura, mídia. Belo Horizonte: Editora UFMG, 2008.

MARTIN, Jessie. Décrire le film de cinema. Paris: Sorbonne nouvelle, 2011.

MARTIN, Marcel. A linguagem cinematográfica. Lisboa: Dinalivro, 2005.

MARKS, Laura. The skin of the film: intercultural cinema, embodiment, and the senses. Durham; Londres: Duke University Press, 2000.

MASCARELLO, Fernando. História do cinema mundial. Campinas: Papirus, 2012.

MERLEAU-PONTY, Maurice. Le cinéma et la nouvelle psychologie (1945). In Sens et Non-sens. Gallimard, 1996. Disponível em

<http://www.acgrenoble.fr/PhiloSophie/logphil/oeuvres/m_ponty/cinema.htm >. Acesso em: 15 mar 2012.

.O olho e o espírito. São Paulo: Cosac \& Naify, 2004

1974.

.O homem e a comunicação: a prosa do mundo. Rio de Janeiro: Bloch Editores,

MESQUITA, Z.; BRANDÃO, C.R. Territórios do cotidiano: uma introdução a novos olhares e experiências. Santa Cruz do Sul: EDUNISC, 1995. 
METZ, Christian. Linguagem e cinema. São Paulo: Perspectiva, 1980.

O significante imaginário. In METZ, Christian et al. Psicanálise e cinema. São Paulo: Global, 1980.

MOINE, Raphaëlle. Les genres du cinéma. Paris, Armand Colin, 2005.

MONTORO, Tânia; CAVALCANTE, Denise. Novas tecnologias e a reconfiguração do público e privado no espaço da casa. Animus - Revista Interamericana de Comunicação Midiática, Santa Maria, v.10 n. 19, 2011. Disponível em $<$ http://repositorio.unb.br/handle/10482/12520>. Acesso em: $01 \mathrm{fev} 2012$.

; CALDAS, Ricardo. A evolução do cinema brasileiro no século XX. Brasília: Casa das Musas, 2006.

Editoral Abaré, 2006.

. (Org.). De olho na imagem. Brasília: Fundação Astrojildo Pereira,

MORIN, Edgar. O cinema ou o homem imaginário. Lisboa: Relógio D’água/Grande Plano, 1997.

MOTTA, Luiz G.. Narratologia: teoria e análise da narrativa jornalística. Brasília: Casa das Musas, 2005.

MOTTE, Jean. Les paysages du cinema. Seyssel: Éditions Champ Vallon, 1999.

MOURA, Hudson. O cinema intercultural na era da globalização. In: FRANÇA, Andréa; LOPES, Denilson (Orgs.). Cinema, globalização, interculturalidade. Chapecó: Argos, 2010. pp. 43-66.

NAGIB, Lúcia; PARENTE, André (Org.) Ozu: o extraordinário cineasta do cotidiano. São Paulo: Marco Zero, 1990.

NESBITT, Kate (Org.). Uma nova agenda para a arquitetura: antologia teórica (19651995). São Paulo: Cosac Naify, 2008.

NORBERG-SCHULZ, Christian. O fenômeno do lugar. In: NESBITT, Kate (Org.). Uma nova agenda para a arquitetura: antologia teórica (1965-1995). São Paulo: Cosac Naify, 2008. pp 443-460.

O pensamento de Heidegger sobre arquitetura. In: NESBITT, Kate (Org.). Uma nova agenda para a arquitetura: antologia teórica (1965-1995). São Paulo: Cosac Naify, 2008. pp 461-473.

NOVAIS, Fernando A. et al. História da vida privada no Brasil. São Paulo: Companhia das Letras, 1997.

ODIN, Roger. De la fiction. Bruxelles: Éditions De Boeck Université, 2000.

OLIVEIRA JUNIOR. Wencesláo Machado de. Chuva de Cinema: entre a natureza e a cultura. Tese (Doutorado em Cinema). Campinas: FE/UNICAMP, 1999.

O que seriam as geografias de cinema? Entre-Lugar, Dourados, MS, ano 1, n. $1,1^{\circ}$ semestre de 2010

Disponível em $\quad<$ http://www.periodicos.ufgd.edu.br/index.php/entrelugar/article/viewFile/617/412>. Acesso em: 08 abr 2012

PALLASMAA, Juhani. Pensamento em Forma: dez ensaios sobre arquitetura. Centro Regional das Beiras da Universidade Católica Portuguesa, 2012.

Os olhos da pele: a arquitetura e os sentidos. São Paulo: Bookman, 2011. 
.The Architecture of image: existential space in cinema. Helsinki: Rakennustieto, 2000.

PARENTE, André. Cinema em trânsito: do dispositivo do cinema ao cinema dispositivo. In: PENAFRIA, Manuela; MARTINS, Índia Mara Martins (Orgs.) Estéticas do digital: cinema e tecnologia. São Paulo: LABCOM, 2007.

. Deleuze e as virtualidades da narrativa cinematográfica. In: RAMOS, Fernão Pessoa (Org.). Teoria contemporânea do cinema, vol 1. São Paulo: Senac, 2004. pp. 253-279.

Narrativa e modernidade: o cinema não-narrativo do pós-guerra. Campinas: Papirus, 2000.

Imagem-máquina. Rio de Janeiro: Editora 34, 1993.

PEIXOTO, Nelson Brissac. Paisagens urbanas. São Paulo: Editora Senac, 2003.

. Ver o invisível: a ética das imagens. In: NOVAES, Adauto (Org.). Ética. São Paulo: Companhia das Letras, 1997. pp. 301-320.

.Passagens da Imagem: pintura, fotografia, cinema, arquitetura. In:

(Org.). Imagem-máquina: a era das tecnologias virtuais. Rio de Janeiro: Editora 34, 1993. pp. 237-52.

PENAFRIA, Manuela; MARTINS, Índia Mara Martins (Org.) Estéticas do digital: cinema e tecnologia. São Paulo: LABCOM, 2007.

PIGANIOL, Pierre. Du nid à la cite. Paris: Dunod, 1970.

PROST, Antoine; VICENT, Gérard (Orgs.). História da vida privada: da primeira guerra a nossos dias. vol. 5. São Paulo, Companhia das Letras, 2009.

PRYSTHON, Ângela; CUNHA, Paulo (Orgs.). Ecos urbanos: a cidade e suas articulações midiáticas. Porto Alegre: Sulina, 2009.

Imagens da cidade: espaços urbanos na comunicação e cultura contemporâneas. Porto Alegre: Sulina, 2006.

RAMOS, Fernão Pessoa (Org.). Teoria contemporânea do cinema, vol.1. São Paulo: Senac, 2004.

(Org.). Teoria contemporânea do cinema, vol.2. São Paulo: Senac, 2004.

RANCIÈRE Jacques. A partilha do sensível: estética e política. São Paulo: Ed. 34, 2005.

La Fábula Cinematográfica: reflexiones sobre la ficción en el cine. Barcelona: Ed. Paidós Ibérica, 2005.

. L'historicité du cinema. In BAECQUE, Antoine de; DELAGE, Christian. De I'histoire au cinema. Paris: Editions Complexe, 1998.

RESNAIS, Alain. As serpentes e o caduceu. In: GRÜNNEWALD, José Lino (Org.). A ideia do cinema. Rio de Janeiro: Civilização Brasileira, 1969. p.117-121.

ROBERTS, Martin. Baraka: o cinema mundial e a indústria cultura global. In: FRANÇA, Andréa e LOPES, Denilson, (Orgs.). Cinema, globalização e interculturalidade. Chapecó, Argos, 2010. pp.17-42.

ROHMER, Éric. L'organisation de l'espace dans le Faust de Murnau. In: COSTA, Antonio. Compreender o cinema. Rio de Janeiro: Globo, 1987. 
. L'organisation de l'espace dans le Faust de Murnau. Paris: Union générale d'éditions, 1977.

SANTAELLA, Lúcia; NÖTH, Winfried. Imagem: cognição, semiótica, mídia. São Paulo: Iluminuras, 2008.

SANTAELLA, Lucia. Comunicação e pesquisa: projetos para mestrado e doutorado. São Paulo: Hacker Editores, 2001.

SANTOS, Boaventura de Sousa. Pela mão de Alice: o social e o político na pósmodernidade. São Paulo: Cortez, 2000.

SANTOS, Milton. A natureza dos espaços: técnica e tempo, razão e emoção. São Paulo: Editora da Universidade de São Paulo, 2009. Paulo, 2008 .

Metamorfoses do espaço habitado. São Paulo: Editora da Universidade de São

.Por uma outra globalização: do pensamento único à consciência universal. Rio de Janeiro: Record, 2008. Paulo, 2007.

.Pensando o espaço do homem. São Paulo: Editora da Universidade de São

.Espaço e sociedade. Petrópolis : Vozes, 1982.

; SOUZA, Maria Adélia; SILVEIRA, Maria (Orgs.). Território: globalização e fragmentação. São Paulo: HUCITEC, 1996.

SENNET, Richard. O Declínio do homem público: as tiranias da intimidade. São Paulo: Companhia das Letras, 1988

SIETY, Emmanuel. Le plan: au commencement du cinéma. Itália: Cahiers du Cinéma, 2001.

SMITH, Murray. Espectatorialidade cinematográfica e a instituição da ficção. In RAMOS, Fernão Pessoa (Org.). Teoria contemporânea do cinema, vol.1. São Paulo: Senac, 2004. pp. 141-170.

SOURIAU, Étienne. Préface. In: SOURIAU, Étienne et al. L'univers filmique. Paris: Flammarion, 1953.

STAM, Robert. Para além do terceiro cinema: estética do hibridismo. In FRANÇA, Andréa; LOPES, Denilson (Orgs.). Cinema, globalização e interculturalidade. Chapecó, SC: Argos, 2010. pp. 107-136.

. Introdução à teoria do cinema. Campinas: Papirus, 2003.

STOCK, Mathis. L'habiter comme pratique des lieux géographiques. Espacestemps.net. Disponível em: $<\underline{\mathrm{http}}$ ://www.espacestemps.net/document1138.html $>$. Acesso em: 10 out 2013.

TUAN, Yi-fu. Topofilia. São Paulo: Difel, 1980.

TUAN, Yi-fu. Espaço e lugar. São Paulo: Difel, 1983.

VANOYE, Francis; GOLIOT-LÉTÉ. Ensaio sobre a análise fílmica. Campinas: Papirus, 1994.

VERNET, Marc In: AUMONT, Jacques et al. A estética do filme. São Paulo: Papirus, 2012. 
VIRILIO, Paul. O espaço crítico. São Paulo: Editora 34, 1993.

WOOD, James. Como funciona a ficção. São Paulo: Cosac Naify, 2012.

XAVIER, Ismail. O discurso cinematográfico: a opacidade e a transparência. São Paulo: Paz e Terra, 2005.

XAVIER, Ismail (Org.). A experiência do cinema: antologia. Rio de Janeiro, Graal/Embrafilme, 1983.

ZEVI, Bruno. Saber ver a arquitetura. São Paulo: Martins Fontes,1996. 


\section{ANEXOS}

1. Quadro de filmes de ficção do cinema mundial

\begin{tabular}{|c|c|c|c|c|}
\hline Título & País & Diretor & Sinopse & $\begin{array}{c}\text { Espaço } \\
\text { narrativo } \\
\text { central }\end{array}$ \\
\hline \multicolumn{5}{|c|}{2000} \\
\hline Através da janela & Brasil & Tata Amaral & $\begin{array}{l}\text { O cotidiano de uma mulher e seu filho entre o espaço doméstico e a vida do dia-a- } \\
\text { dia. }\end{array}$ & Casa \\
\hline $\begin{array}{l}\text { Happy times } \\
\text { (Xingfu Shiguang) }\end{array}$ & China & $\begin{array}{l}\text { Zhang } \\
\text { Yimou }\end{array}$ & $\begin{array}{l}\text { Homem aceita se casar com uma viúva gananciosa. Para conseguir o dinheiro, } \\
\text { transforma um velho ônibus em um motel ambulante. }\end{array}$ & $\begin{array}{l}\text { Casa } \\
\text { Ônibus-motel }\end{array}$ \\
\hline $\begin{array}{l}\text { Onde mora o } \\
\text { coracão (Where the } \\
\text { Heart IS) }\end{array}$ & EUA & $\begin{array}{l}\text { Matt } \\
\text { Williams }\end{array}$ & $\begin{array}{l}\text { Jovem grávida é abandonada pelo namorado em frente a um supermercado. Sem } \\
\text { dinheiro, passa a morar no mercado até dar à luz dentro da loja. }\end{array}$ & $\begin{array}{l}\text { Supermercado } \\
\text { Casa }\end{array}$ \\
\hline $\begin{array}{l}\text { Encontrando } \\
\text { Forrest (Finding } \\
\text { Forrest) }\end{array}$ & EUA & $\begin{array}{l}\text { Gus Van } \\
\text { Sant }\end{array}$ & Escritor famoso recluso incentiva jovem da periferia a se tornar escritor. & $\begin{array}{l}\text { Casa } \\
\text { Escola }\end{array}$ \\
\hline $\begin{array}{l}\text { Pão e Rosas } \\
\text { (Bread and Roses) }\end{array}$ & $\begin{array}{l}\text { França, } \\
\text { Inglaterra } \\
\text { Suiça } \\
\text { Espanha } \\
\text { Alemanha }\end{array}$ & Ken Loach & $\begin{array}{l}\text { Jovem mexicana passa a viver com sua irmã nos Estados Unidos. Trabalhando como } \\
\text { garçonete e faxineira, acaba conhecendo outros estrangeiros que, assim como ela, } \\
\text { vivem em péssimas condições. }\end{array}$ & $\begin{array}{l}\text { Casa } \\
\text { Escritório }\end{array}$ \\
\hline $\begin{array}{l}\text { As coisas simples da } \\
\text { vida }(Y i Y i)\end{array}$ & $\begin{array}{l}\text { Taiwan } \\
\text { Japão }\end{array}$ & $\begin{array}{l}\text { Edward } \\
\text { Yang }\end{array}$ & $\begin{array}{l}\text { Cotidiano de um homem de classe média e sua família após derrame e coma da sogra } \\
\text { idosa. }\end{array}$ & Casa \\
\hline $\begin{array}{l}\text { Amor à flor da pele } \\
\text { (Fa Yeung nin wa) }\end{array}$ & $\begin{array}{l}\text { França } \\
\text { Hong Kong }\end{array}$ & $\begin{array}{l}\text { Wong Kar- } \\
\text { Wai }\end{array}$ & $\begin{array}{l}\text { Recém vizinhos se conhecem e se tornam amigos. Com a constante ausência dos } \\
\text { respectivos companheiros, acabam se dando conta de suas traições. }\end{array}$ & $\begin{array}{l}\text { Casa } \\
\text { Edifício }\end{array}$ \\
\hline \multicolumn{5}{|c|}{2001} \\
\hline $\begin{array}{l}\text { Dez } \\
(\text { Ten })\end{array}$ & $\begin{array}{l}\text { EUA } \\
\text { Irã } \\
\text { França }\end{array}$ & $\begin{array}{l}\text { Abbas } \\
\text { Kiarostami }\end{array}$ & $\begin{array}{l}\text { Dez sequências de percursos de carro com uma mulher dirigindo e vivendo situações } \\
\text { cotidianas. }\end{array}$ & Carro \\
\hline $\begin{array}{l}\text { O quarto do filho } \\
\text { (La stanza del figlio) }\end{array}$ & $\begin{array}{l}\text { Itália } \\
\text { França }\end{array}$ & $\begin{array}{l}\text { Nanni } \\
\text { Moretti }\end{array}$ & $\begin{array}{l}\text { A vida de Giovanni transcorre tranquila, entre a família e o consultório, até o } \\
\text { incidente que culmina na morte de seu filho. }\end{array}$ & $\begin{array}{l}\text { Casa } \\
\text { Estrada }\end{array}$ \\
\hline
\end{tabular}




\begin{tabular}{|c|c|c|c|c|}
\hline $\begin{array}{l}\text { O filho da noiva } \\
\text { (El hijo de la novia) }\end{array}$ & $\begin{array}{l}\text { Espanha } \\
\text { Argentina }\end{array}$ & $\begin{array}{l}\text { Juan José } \\
\text { Campanella }\end{array}$ & $\begin{array}{l}\text { Homem em crise tem ataque cardíaco e com a ajuda de um amigo de infância tenta } \\
\text { reconstruir suas relações familiares e amorosas. }\end{array}$ & $\begin{array}{l}\text { Restaurante } \\
\text { Casa } \\
\text { Asilo }\end{array}$ \\
\hline $\begin{array}{l}\text { Agora ou nunca } \\
\text { (All or nothing) }\end{array}$ & $\begin{array}{l}\text { França } \\
\text { Inglaterra }\end{array}$ & Mike Leigh & $\begin{array}{l}\text { Um taxista e uma caixa de supermercado encaram com dificuldade a gravidez de sua } \\
\text { filha solteira e o filho problemático. Após internação do filho, o casal resolve mudar } \\
\text { sua triste situação familiar. }\end{array}$ & $\begin{array}{l}\text { Casa } \\
\text { Edifício } \\
\text { Hospital }\end{array}$ \\
\hline $\begin{array}{l}\text { Millennium Mambo } \\
\text { (Qian xi man) }\end{array}$ & $\begin{array}{l}\text { Taiwan } \\
\text { França }\end{array}$ & $\begin{array}{l}\text { Hou Hsiao } \\
\text { Hsien }\end{array}$ & $\begin{array}{l}\text { Jovem relembra sua juventude e sua vida amorosa pregressa entre seu chefe protetor } \\
\text { e um namorado cafajeste. }\end{array}$ & $\begin{array}{l}\text { Casa } \\
\text { Bar, boate }\end{array}$ \\
\hline \multicolumn{5}{|c|}{2002} \\
\hline Durval Discos & Brasil & $\begin{array}{l}\text { Anna } \\
\text { Muylaert }\end{array}$ & $\begin{array}{l}\text { Durval e sua mãe vivem em uma casa onde funciona a loja Durval Discos, que apesar } \\
\text { dos novos tempos, insiste na venda de discos. }\end{array}$ & Casa, loja \\
\hline $\begin{array}{l}\text { Dois perdidos numa } \\
\text { noite suja }\end{array}$ & Brasil & José Joffily & Dois estrangeiros dividem um galpão abandonado na cidade de Nova Iorque. & $\begin{array}{l}\text { Galpão } \\
\text { abandonado }\end{array}$ \\
\hline $\begin{array}{l}\text { Fale com ela } \\
\text { (Hable com ella) }\end{array}$ & Espanha & $\begin{array}{l}\text { Pedro } \\
\text { Almodóvar }\end{array}$ & $\begin{array}{l}\text { Benigno é enfermeiro e observa a bailarina Alicia em suas aulas de balé em academia } \\
\text { vizinha. Após acidente, Alicia é internada e passa a ser cuidada por Benigno. }\end{array}$ & $\begin{array}{l}\text { Hospital } \\
\text { Academia }\end{array}$ \\
\hline O invasor & Brasil & Beto Brant & $\begin{array}{l}\text { Um matador de aluguel é contratado para assassinar um dos sócios de uma } \\
\text { construtora mas acaba invadindo cada vez mais a vida dos proprietários. }\end{array}$ & $\begin{array}{l}\text { Casa, ruas, } \\
\text { empresa }\end{array}$ \\
\hline Dolls & Japão & $\begin{array}{l}\text { Takeshi } \\
\text { Kitano }\end{array}$ & $\begin{array}{l}\text { Três histórias de amor inspiradas no espetáculo de bonecos do teatro japonês Bunraku } \\
\text { exploram conflitos familiares e sociais. }\end{array}$ & $\begin{array}{l}\text { Ruas } \\
\text { Parque }\end{array}$ \\
\hline Cidade de Deus & Brasil & $\begin{array}{l}\text { Fernando } \\
\text { Meirelles e } \\
\text { Kátia Lund }\end{array}$ & $\begin{array}{l}\text { O dia-a-dia de uma favela no Rio de Janeiro apresentado em três períodos diferentes } \\
\text { e sob o olhar de um jovem fotógrafo. }\end{array}$ & Favela \\
\hline \multicolumn{5}{|c|}{2003} \\
\hline $\begin{array}{l}\text { Encontros e } \\
\text { desencontros } \\
\text { (Lost in translation) }\end{array}$ & EUA & $\begin{array}{l}\text { Sofia } \\
\text { Coppola }\end{array}$ & $\begin{array}{l}\text { Hóspedes do mesmo hotel, Charlotte e Bob se conhecem e consolidam uma breve e } \\
\text { profunda amizade. }\end{array}$ & $\begin{array}{l}\text { Hotel como } \\
\text { morada }\end{array}$ \\
\hline $\begin{array}{l}\text { A menina santa } \\
\text { (La nina santa) }\end{array}$ & Argentina & $\begin{array}{l}\text { Lucrecia } \\
\text { Martel }\end{array}$ & $\begin{array}{l}\text { Amália tem uma filha conservadora. Um dia recebe em seu hotel um médico que } \\
\text { acaba se envolvendo com sua filha. }\end{array}$ & Hotel \\
\hline Whisky & Uruguai & $\begin{array}{l}\text { Pablo Stoll } \\
\text { Ward, } \\
\text { Juan Pablo } \\
\text { Rebella }\end{array}$ & $\begin{array}{l}\text { Dono de uma fábrica de meias propõe a sua supervisora solteirona assumir o papel } \\
\text { de sua esposa durante a estadia de seu irmão. A situação acaba retomando antigas } \\
\text { rivalidades. }\end{array}$ & $\begin{array}{l}\text { Casa } \\
\text { Estrada }\end{array}$ \\
\hline $\begin{array}{l}\text { Adeus, Dragon Inn } \\
\text { (Goodbye Dragon } \\
\text { Inn) }\end{array}$ & Taiwan & $\begin{array}{l}\text { Ming-Liang } \\
\text { Tsai }\end{array}$ & $\begin{array}{l}\text { Na última sessão de um cinema, espectadores perambulam, cada um à procura de } \\
\text { algo. }\end{array}$ & Sala de cinema \\
\hline
\end{tabular}




\begin{tabular}{|c|c|c|c|c|}
\hline $\begin{array}{l}\text { 2046, Os segredos } \\
\text { do amor } \\
(2046)\end{array}$ & $\begin{array}{l}\text { HongKong } \\
\text { França } \\
\text { Itália/China }\end{array}$ & $\begin{array}{l}\text { Wong Kar- } \\
\text { Wai }\end{array}$ & $\begin{array}{l}\text { Um jornalista se hospeda em um hotel, enquanto escreve um livro de ficção. Lá, } \\
\text { conhece mulheres que o fazem lembrar-se de seu passado amoroso. }\end{array}$ & Hotel \\
\hline $\begin{array}{l}\text { Família rodante } \\
\text { (Familia rodante) }\end{array}$ & Argentina & $\begin{array}{l}\text { Pablo } \\
\text { Trapero }\end{array}$ & $\begin{array}{l}\text { Família viaja em uma espécie de trailer até a cidade natal da avó. Durante a viagem, } \\
\text { as diferentes gerações partilham sonhos e frustrações. }\end{array}$ & $\begin{array}{l}\text { Carro como } \\
\text { morada }\end{array}$ \\
\hline $\begin{array}{l}\text { Brilho eterno de } \\
\text { uma mente sem } \\
\text { lembranças (Eternal } \\
\text { Sunshine of the } \\
\text { Spotless Mind) }\end{array}$ & EUA & $\begin{array}{l}\text { Michel } \\
\text { Gondry }\end{array}$ & $\begin{array}{l}\text { Após história de amor tumultuada, casal apaga de sua memória acontecimentos } \\
\text { passados. É tentando apagar a memória, que Joel se lembra o quanto ama Clementine. }\end{array}$ & $\begin{array}{l}\text { Casa } \\
\text { Clínica } \\
\text { Ruas }\end{array}$ \\
\hline Elefante (Elephant) & EUA & $\begin{array}{l}\text { Gus Van } \\
\text { Sant }\end{array}$ & $\begin{array}{l}\text { Dois jovens invadem uma escola, munidos de um arsenal de armas que vinham } \\
\text { colecionando, e se tornam os protagonistas de uma grande tragédia americana. }\end{array}$ & Escola \\
\hline \multicolumn{5}{|c|}{2004} \\
\hline $\begin{array}{l}\text { Café Lumière } \\
\text { (Kohi Jikou) }\end{array}$ & Taiwan Japão & $\begin{array}{l}\text { Hou Hsiao- } \\
\text { hsien }\end{array}$ & $\begin{array}{l}\text { Yoko anuncia aos pais que está grávida. Em seu dia-a-dia, se desloca o tempo todo, } \\
\text { entre sua casa e a casa dos pais, para visitar seu amigo dono de um sebo de livros e } \\
\text { nas vias do metrô entre um ponto e outro da cidade. }\end{array}$ & $\begin{array}{l}\text { Casa } \\
\text { Metrô } \\
\text { Sebo }\end{array}$ \\
\hline O Outro lado da rua & Brasil & $\begin{array}{l}\text { Marcos } \\
\text { Bernstein }\end{array}$ & $\begin{array}{l}\text { Mulher solitária vira informante da polícia, denunciando pequenos delitos. Em uma } \\
\text { noite, presencia um assassinato. }\end{array}$ & Casa \\
\hline $\begin{array}{l}\text { A casa vazia } \\
\text { (Bin jip) }\end{array}$ & Coréia do Sul & Kim Ki-Duk & $\begin{array}{l}\text { Um jovem errante invade casas de estranhos e passa a habitar nelas durante a } \\
\text { ausência de seus moradores. }\end{array}$ & Casas \\
\hline $\begin{array}{l}\text { Terminal } \\
\text { (The Terminal) }\end{array}$ & EUA & $\begin{array}{l}\text { Steven } \\
\text { Spielberg }\end{array}$ & $\begin{array}{l}\text { Imigrante fica retido no aeroporto de Nova York devido a um golpe em seu país. Ele } \\
\text { passa a morar no próprio terminal, interagindo com os funcionários do lugar. }\end{array}$ & Aeroporto \\
\hline $\begin{array}{l}\text { Contra a parede } \\
\text { (Gegen die Wand) }\end{array}$ & $\begin{array}{l}\text { Turquia, } \\
\text { Alemanha }\end{array}$ & Fatih Akin & $\begin{array}{l}\text { Jovem muçulmana conhece turco em clínica de recuperação e acaba se casando com } \\
\text { ele para fugir de sua família, mas uma paixão acaba mudando a situação. }\end{array}$ & Casa \\
\hline $\begin{array}{l}\text { O Abraço partido } \\
\text { (El abrazo partido) }\end{array}$ & Argentina & $\begin{array}{l}\text { Daniel } \\
\text { Burman }\end{array}$ & $\begin{array}{l}\text { Em uma galeria de Buenos Aires, todos os lojistas são estrangeiros. Ariel é um jovem } \\
\text { judeu que se prepara para adquirir a cidadania polonesa e reencontrar o pai ausente. }\end{array}$ & Galeria de lojas \\
\hline $\begin{array}{l}\text { Antes do pôr-do-sol } \\
\text { (Before sunset) }\end{array}$ & EUA & $\begin{array}{l}\text { Richard } \\
\text { Linklater }\end{array}$ & $\begin{array}{l}\text { Casal se conhece em viagem e passa o dia juntos. Anos depois, ele um escritor, ela } \\
\text { uma ambientalista, se reencontram em Paris e andam pela cidade relembrando o } \\
\text { passado e discutindo a relação. }\end{array}$ & $\begin{array}{l}\text { Ruas } \\
\text { Restaurante }\end{array}$ \\
\hline O mundo (Shijie) & $\begin{array}{l}\text { Japão } \\
\text { China } \\
\end{array}$ & Jia Zhang-ke & $\begin{array}{l}\text { O cotidiano dos funcionários de um parque temático nos arredores de Pequim, suas } \\
\text { inquietações e solidão cotidiana. }\end{array}$ & Parque \\
\hline \multicolumn{5}{|c|}{2005} \\
\hline Caché & $\begin{array}{l}\text { França/Itália } \\
\text { Áustria/ } \\
\text { Alemanha } \\
\end{array}$ & $\begin{array}{l}\text { Michael } \\
\text { Haneke }\end{array}$ & $\begin{array}{l}\text { Casal recebe fita de vídeo com imagens de sua casa filmada por uma câmara. } \\
\text { Assustados, passam a tentar descobrir o autor das imagens. }\end{array}$ & Casa \\
\hline
\end{tabular}




\begin{tabular}{|c|c|c|c|c|}
\hline $\begin{array}{l}\text { Marcas da violência } \\
\text { (A history of } \\
\text { violence) }\end{array}$ & EUA & $\begin{array}{l}\text { David } \\
\text { Cronenberg }\end{array}$ & $\begin{array}{l}\text { Pai de família pacato vê sua vida se transformar após matar um homem em um } \\
\text { restaurante em legítima defesa. }\end{array}$ & $\begin{array}{l}\text { Restaurante } \\
\text { Casa }\end{array}$ \\
\hline Volver & Espanha & $\begin{array}{l}\text { Pedro } \\
\text { Almodóvar }\end{array}$ & As diferentes gerações de mulheres de uma família envolvidas em um assassinato. & $\begin{array}{l}\text { Restaurante } \\
\text { Casa }\end{array}$ \\
\hline $\begin{array}{l}\text { Ponto Final (Match } \\
\text { Point) }\end{array}$ & \begin{tabular}{|l|} 
EUA \\
Inglaterra \\
\end{tabular} & $\begin{array}{l}\text { Woody } \\
\text { Allen }\end{array}$ & $\begin{array}{l}\text { Professor de tênis ambicioso se casa com jovem da alta sociedade e tem sua situação } \\
\text { social transformada, quando conhece bela atriz americana e se torna seu amante. }\end{array}$ & $\begin{array}{l}\text { Clube de tênis } \\
\text { Casa }\end{array}$ \\
\hline $\begin{array}{l}\text { Café transit (Border } \\
\text { Café) }\end{array}$ & Iraniano & $\begin{array}{l}\text { Kambozia } \\
\text { Partovi }\end{array}$ & $\begin{array}{l}\text { Jovem iraniana viúva e mãe de dois filhos se vê pressionada a casar com seu genro } \\
\text { mas prefere reabrir o antigo café de estrada de seu falecido marido. }\end{array}$ & $\begin{array}{l}\text { Casa } \\
\text { Café }\end{array}$ \\
\hline Hooligans & $\begin{array}{l}\text { EUA } \\
\text { Inglaterra }\end{array}$ & $\begin{array}{l}\text { Lexi } \\
\text { Alexander }\end{array}$ & $\begin{array}{l}\text { Expulso de uma universidade americana, jovem volta a viver com sua irmã na } \\
\text { Inglaterra. Influenciado pelos colegas, passa a participar de torcidas de futebol } \\
\text { violentas e extremistas. }\end{array}$ & $\begin{array}{l}\text { Estádios } \\
\text { Bares }\end{array}$ \\
\hline $\begin{array}{l}\text { Flores Partidas } \\
\text { (Broken flowers) }\end{array}$ & EUA & $\begin{array}{l}\text { Jim } \\
\text { Jarmusch }\end{array}$ & $\begin{array}{l}\text { Ao receber uma carta anônima informando que tem um filho, homem sai à procura } \\
\text { do filho visitando antigas companheiras. }\end{array}$ & Casa \\
\hline \multicolumn{5}{|c|}{2006} \\
\hline O céu de Suely & Brasil & $\begin{array}{l}\text { Karim } \\
\text { Aïnouz }\end{array}$ & $\begin{array}{l}\text { Jovem volta a sua cidade-natal com filho pequeno e aguarda a chegada do marido } \\
\text { que não aparece. Decidida a ir embora, decide rifar seu próprio corpo em troca de } \\
\text { dinheiro. }\end{array}$ & $\begin{array}{l}\text { Casa } \\
\text { Ruas }\end{array}$ \\
\hline $\begin{array}{l}\text { Eu não quero } \\
\text { dormir sozinho }(H e i \\
\text { yan quan) }\end{array}$ & $\begin{array}{l}\text { Taiwan/ } \\
\text { França/ } \\
\text { Áustria }\end{array}$ & $\begin{array}{l}\text { Tsai Ming- } \\
\text { Liang }\end{array}$ & $\begin{array}{l}\text { Jovens à margem da sociedade recolhem morador de rua em morada improvisada e } \\
\text { passam a cuidar dele até que se recupere. }\end{array}$ & Moradia precária \\
\hline $\begin{array}{l}\text { Não se preocupe, } \\
\text { estou bem (Je vais } \\
\text { bien, ne t'en fait pas) }\end{array}$ & França & $\begin{array}{l}\text { Philippe } \\
\text { Lioret }\end{array}$ & $\begin{array}{l}\text { Uma jovem entra em crise após saber que seu irmão saiu de casa. Ela resolve partir } \\
\text { em busca do irmão. }\end{array}$ & Casa \\
\hline $\begin{array}{l}\text { Invasão de domicílio } \\
\text { (Breaking and } \\
\text { entering) }\end{array}$ & EUA & $\begin{array}{l}\text { Anthony } \\
\text { Minghella }\end{array}$ & $\begin{array}{l}\text { Arquiteto muda seu escritório para centro urbano, mas acaba se tornando alvo de } \\
\text { ladrões. Ao seguir um dos assaltantes, conhece sua mãe, uma refugiada, e acaba se } \\
\text { envolvendo emocionalmente com ela. }\end{array}$ & $\begin{array}{l}\text { Escritório } \\
\text { Casa }\end{array}$ \\
\hline $\begin{array}{l}\text { O amor não tira } \\
\text { férias (The Holiday) }\end{array}$ & EUA & $\begin{array}{l}\text { Nancy } \\
\text { Meyers }\end{array}$ & $\begin{array}{l}\text { Duas jovens desconhecidas, uma americana e outra inglesa, descontentes com suas } \\
\text { vidas amorosas resolvem trocar de casa durante as férias. }\end{array}$ & Casa \\
\hline $\begin{array}{l}\text { Amar não tem preço } \\
\text { (Hors de prix) }\end{array}$ & França & $\begin{array}{l}\text { Pierre } \\
\text { Salvadori }\end{array}$ & Jovem interesseira conhece um tímido garçom e acaba o confundindo com um ricaço. & Hotel \\
\hline $\begin{array}{l}\text { Em Paris } \\
\text { (Dans Paris) }\end{array}$ & França & $\begin{array}{l}\text { Christophe } \\
\text { Honoré }\end{array}$ & $\begin{array}{l}\text { Mirko tem dois filhos: Paul que enfrenta problemas de depressão, e Jonathan, um } \\
\text { jovem irresponsável. Paul volta a morar com o pai, enquanto Jonathan vive aventuras } \\
\text { românticas pela cidade. }\end{array}$ & $\begin{array}{l}\text { Casa } \\
\text { Ruas }\end{array}$ \\
\hline $\begin{array}{l}\text { Sempre Bela } \\
\text { (Belle toujours) }\end{array}$ & \begin{tabular}{|l|} 
Portugal \\
França \\
\end{tabular} & $\begin{array}{l}\text { Manoel de } \\
\text { Oliveira }\end{array}$ & $\begin{array}{l}\text { Depois de descobrir que a esposa de um amigo se prostituía, homem a convence a } \\
\text { jantar em seu hotel. }\end{array}$ & Hotel \\
\hline
\end{tabular}




\begin{tabular}{|c|c|c|c|c|}
\hline $\begin{array}{l}\text { Bonecas russas } \\
\text { (Les Poupées russes) }\end{array}$ & França & $\begin{array}{l}\text { Cédric } \\
\text { Kaplish }\end{array}$ & $\begin{array}{l}\text { Escritor de telenovelas dividido entre o amor de várias mulheres, conta com a ajuda } \\
\text { de uma amiga lésbica para encontrar o verdadeiro amor. }\end{array}$ & $\begin{array}{l}\text { Casa } \\
\text { Ruas }\end{array}$ \\
\hline $\begin{array}{l}\text { Separados pelo } \\
\text { casamento } \\
(\text { The Break-Up) }\end{array}$ & EUA & Peyton Reed & Casal disputa posse do apartamento após intenção de divórcio. & Casa \\
\hline $\begin{array}{l}\text { Pecados intimos } \\
\text { (Little Children) }\end{array}$ & EUA & Todd Field & $\begin{array}{l}\text { Mulher casada conhece homem casado em um parque perto de sua casa. É o início } \\
\text { de um caso extraconjugal. }\end{array}$ & Casa \\
\hline Volver & Espanha & $\begin{array}{l}\text { Pedro } \\
\text { Almodóvar }\end{array}$ & $\begin{array}{l}\text { Raimunda vive seu dia-a-dia entre problemas financeiros e uma família problemática } \\
\text { até que sua filha confessa ter matado o pai após tentativa de abuso sexual. }\end{array}$ & $\begin{array}{l}\text { Casa } \\
\text { Restaurante }\end{array}$ \\
\hline \multicolumn{5}{|c|}{2007} \\
\hline $\begin{array}{l}\text { A viagem do balão } \\
\text { branco (Le voyage } \\
\text { du ballon rouge) }\end{array}$ & $\begin{array}{l}\text { França/ } \\
\text { Taiwan }\end{array}$ & $\begin{array}{l}\text { Hou Hsiao- } \\
\text { Hsien }\end{array}$ & $\begin{array}{l}\text { Suzanne trabalha com espetáculos de fantoche e mora com seu filho em Paris. O } \\
\text { menino vê um balão vermelho flutuando sobre os telhados da cidade enquanto a mãe } \\
\text { lida com as intempéries diárias. }\end{array}$ & Casa \\
\hline $\begin{array}{l}\text { A banda } \\
\text { (Bikur ha-tizmoret) }\end{array}$ & $\begin{array}{l}\text { Israel, EUA, } \\
\text { França }\end{array}$ & Eran Kolirin & $\begin{array}{l}\text { Músicos de uma banda egípcia chegam a Israel para um evento e acabam esquecidos } \\
\text { no aeroporto. Sem compreender a língua, acabam perdidos em um vilarejo e são } \\
\text { hospedados nas casas dos moradores locais. }\end{array}$ & $\begin{array}{l}\text { Casa } \\
\text { Prédio de moradia }\end{array}$ \\
\hline A Casa de Alice & Brasil & $\begin{array}{l}\text { Chico } \\
\text { Teixeira }\end{array}$ & $\begin{array}{l}\text { Alice é uma manicure que mora na periferia de São Paulo. Ao lado de sua família, } \\
\text { enfrenta os problemas do dia-a-dia. }\end{array}$ & Casa \\
\hline $\begin{array}{l}\text { As testemunhas } \\
\text { (Les témoins) }\end{array}$ & França & $\begin{array}{l}\text { André } \\
\text { Téchiné }\end{array}$ & $\begin{array}{l}\text { Jovem chega a Paris em busca de emprego e divide um quarto de hotel com sua irmã. } \\
\text { Um dia, conhece um médico homossexual. }\end{array}$ & Hotel \\
\hline $\begin{array}{l}4 \text { meses, } 3 \text { semanas e } \\
2 \text { dias (4 luni, } 3 \\
\text { saptamâni si } 2 \text { zile) }\end{array}$ & $\begin{array}{l}\text { Romênia } \\
\text { Bélgica }\end{array}$ & $\begin{array}{l}\text { Cristian } \\
\text { Mungiu }\end{array}$ & $\begin{array}{l}\text { Otilia e Gabita são colegas em uma pequena cidade romena. Gabita está grávida e o } \\
\text { aborto é ilegal. Otilia aluga um quarto num hotel para resolver a questão. }\end{array}$ & $\begin{array}{l}\text { Hotel } \\
\text { Dormitório } \\
\text { estudantil }\end{array}$ \\
\hline $\begin{array}{l}\text { Meu mundo em } \\
\text { perigo }\end{array}$ & Brasil & $\begin{array}{l}\text { José } \\
\text { Eduardo } \\
\text { Belmonte }\end{array}$ & $\begin{array}{l}\text { Elias, após matar um homem, se esconde em um hotel decadente no centro de São } \\
\text { Paulo. Junto com uma garota que também foge de seus problemas, Elias busca } \\
\text { encontrar sentido para sua vida. }\end{array}$ & $\begin{array}{l}\text { Hotel } \\
\text { Ruas }\end{array}$ \\
\hline $\begin{array}{l}\text { Na cidade de Silvia } \\
\text { (En la ciudad de } \\
\text { Sylvia) }\end{array}$ & $\begin{array}{l}\text { Espanha } \\
\text { França }\end{array}$ & $\begin{array}{l}\text { José Luis } \\
\text { Guerín }\end{array}$ & $\begin{array}{l}\text { Um jovem retorna à cidade de Estrasburgo e passa seu tempo percorrendo ruas e } \\
\text { observando mulheres na tentativa de reencontrar Silvia. }\end{array}$ & Ruas \\
\hline \multicolumn{5}{|c|}{2008} \\
\hline $\begin{array}{l}\text { A partida } \\
\text { (Okuribito) }\end{array}$ & Japão & $\begin{array}{l}\text { Yojiro } \\
\text { Takita }\end{array}$ & $\begin{array}{l}\text { Jovem violoncelista passa a trabalhar como assistente funerário preparando pessoas } \\
\text { mortas para o enterro. }\end{array}$ & Casas \\
\hline Entre Lençóis & Brasil & $\begin{array}{l}\text { Gustavo } \\
\text { Nieto Roa }\end{array}$ & $\begin{array}{l}\text { Paula e Roberto se conhecem em uma boate. Sem trocar muitas palavras, se } \\
\text { hospedam em um motel, onde passam a noite. }\end{array}$ & Motel \\
\hline
\end{tabular}




\begin{tabular}{|c|c|c|c|c|}
\hline $\begin{array}{l}\text { Um beijo roubado } \\
\text { (My Blueberry } \\
\text { Nights) }\end{array}$ & $\begin{array}{l}\text { França } \\
\text { China } \\
\text { HongKong }\end{array}$ & $\begin{array}{l}\text { Wong Kar- } \\
\text { Wai }\end{array}$ & $\begin{array}{l}\text { Jeremy administra um café em Nova York. Uma cliente briga com o namorado e } \\
\text { deixa as chaves do apartamento com ele. A jovem parte em viagem, enquanto Jeremy } \\
\text { a aguarda. }\end{array}$ & Cafeteria \\
\hline $\begin{array}{l}\text { Entre os muros da } \\
\text { escola (Entre les } \\
\text { murs) }\end{array}$ & França & $\begin{array}{l}\text { Laurent } \\
\text { Cantet }\end{array}$ & $\begin{array}{l}\text { François trabalha como professor em uma escola da periferia de Paris. Ele e seus } \\
\text { colegas de ensino buscam apoio mútuo na difícil tarefa de educar adolescentes } \\
\text { rebeldes. }\end{array}$ & Escola \\
\hline $\begin{array}{l}\text { A fronteira da } \\
\text { alvorada }(L a \\
\text { frontière de l'aube) }\end{array}$ & França & $\begin{array}{l}\text { Philippe } \\
\text { Garrel }\end{array}$ & $\begin{array}{l}\text { Atriz casada vive um caso amoroso com um fotógrafo enquanto seu marido } \\
\text { permanece nos EUA a trabalho. Após seu retorno, a vida dos amantes se complica. }\end{array}$ & Casa \\
\hline $\begin{array}{l}\text { A onda } \\
\text { (Die Welle) }\end{array}$ & Alemanha & $\begin{array}{l}\text { Dennis } \\
\text { Gansel }\end{array}$ & $\begin{array}{l}\text { Professor de escola na Alemanha é designado a lecionar disciplina de autocracia. } \\
\text { Decide então mostrar de modo prático como se forma um governo fascista usando } \\
\text { seus próprios alunos como cobaias. }\end{array}$ & Escola \\
\hline Home & Bélgica & $\begin{array}{l}\text { Ursula } \\
\text { Meier }\end{array}$ & $\begin{array}{l}\text { Uma família vive isolada na beira de uma autoestrada. A retomada de sua construção } \\
\text { inferniza a vida em família. }\end{array}$ & Casa \\
\hline Linha de passe & $\begin{array}{l}\text { Brasil } \\
\text { EUA }\end{array}$ & $\begin{array}{l}\text { Walter } \\
\text { Salles, Danie } \\
\text { la Thomas }\end{array}$ & $\begin{array}{l}\text { Criados unicamente pela mãe, quatro irmãos lidam com as dificuldades diárias diante } \\
\text { da ausência de uma figura paterna. }\end{array}$ & Casa \\
\hline $\begin{array}{l}\text { O homem mau } \\
\text { dorme bem }\end{array}$ & Brasil & $\begin{array}{l}\text { Geraldo } \\
\text { Moraes }\end{array}$ & $\begin{array}{l}\text { Rita é a dona de um posto de gasolina, Wesley é um vendedor de DVDs piratas e } \\
\text { Caburé é borracheiro. Três destinos que se cruzam em um mesmo lugar. }\end{array}$ & Posto de gasolina \\
\hline \multicolumn{5}{|c|}{2009} \\
\hline $\begin{array}{l}\text { O homem ao lado } \\
\text { (El Hombre de al } \\
\text { Lado) }\end{array}$ & Argentina & $\begin{array}{l}\text { Mariano } \\
\text { Cohn e } \\
\text { Gastón } \\
\text { Duprat }\end{array}$ & $\begin{array}{l}\text { A única residência projetada pelo arquiteto Le Corbusier na cidade de La Plata, na } \\
\text { Argentina, serve de cenário para uma briga entre vizinhos. }\end{array}$ & Casa \\
\hline Management & EUA & $\begin{array}{l}\text { Stephen } \\
\text { Belber }\end{array}$ & $\begin{array}{l}\text { Mike mora e trabalha em um hotel de beira de estrada que pertence a seus pais. Sua } \\
\text { vida é bem pacata até o dia em que a executiva Sue se hospeda no local. }\end{array}$ & Hotel \\
\hline $\begin{array}{l}\text { Benvindo } \\
\text { (Welcome) }\end{array}$ & França & $\begin{array}{l}\text { Philippe } \\
\text { Lioret }\end{array}$ & $\begin{array}{l}\text { Jovem que vive ilegalmente tenta atravessar o canal da Mancha. O professor de } \\
\text { natação tenta ajuda-lo mas acaba tendo problemas com a justiça francesa. }\end{array}$ & $\begin{array}{l}\text { Casa } \\
\text { Piscina }\end{array}$ \\
\hline $\begin{array}{l}\text { Distante nós vamos } \\
(\text { Away we go) }\end{array}$ & EUA & Sam Mendes & $\begin{array}{l}\text { Quando descobre que está esperando um filho, casal viaja pelos Estados Unidos em } \\
\text { busca do melhor lugar para começar uma família. }\end{array}$ & $\begin{array}{l}\text { Casa } \\
\text { Ruas }\end{array}$ \\
\hline $\begin{array}{l}\text { Amantes } \\
\text { (Two Lovers) }\end{array}$ & EUA & James Grey & $\begin{array}{l}\text { Seus pais, preocupados com a tentativa de suicídio de Leonard, tentam fazer com que } \\
\text { ele namore a filha de um amigo. Porém, o jovem se interessa pela vizinha. }\end{array}$ & Casa \\
\hline Zona Sur & Bolivia & $\begin{array}{l}\text { Juan Carlos } \\
\text { Valdivia }\end{array}$ & $\begin{array}{l}\text { Numa mansão da Zona Sul de La Paz, vive Carola e seus filhos. Seu cotidiano pacato } \\
\text { passa por transformações com a perda dos privilégios aristocráticos. }\end{array}$ & Casa \\
\hline Hotel Atlântico & Brasil & $\begin{array}{l}\text { Suzana } \\
\text { Amaral }\end{array}$ & $\begin{array}{l}\text { Alberto é um ator desempregado e vive no Hotel Atlântico. Um dia, após ver o IML } \\
\text { retirar um cadáver do hotel, decide iniciar uma nova jornada. }\end{array}$ & Hotel \\
\hline
\end{tabular}




\begin{tabular}{|c|c|c|c|c|}
\hline $\begin{array}{l}\text { Dois irmãos } \\
\text { (Dos hermanos) }\end{array}$ & Argentina & $\begin{array}{l}\text { Daniel } \\
\text { Burman }\end{array}$ & $\begin{array}{l}\text { Susana deixou a tarefa de cuidar da mãe para seu irmão Marcos. Quando sua mãe } \\
\text { morre, sua irmã o expulsa de seu apartamento e ele resolve se mudar para um resort } \\
\text { no Uruguai. }\end{array}$ & Casa \\
\hline $\begin{array}{l}\text { O concerto } \\
(\text { Le concert })\end{array}$ & $\begin{array}{l}\text { Bélgica } \\
\text { Rússia } \\
\text { Romênia } \\
\text { França/Itália }\end{array}$ & $\begin{array}{l}\text { Radu } \\
\text { Mihaileanu }\end{array}$ & $\begin{array}{l}\text { Após interpelar convite para a filarmônica de Bolshoi, um antigo maestro resolve } \\
\text { montar sua própria orquestra e substituí-la no concerto em Paris. }\end{array}$ & $\begin{array}{l}\text { Teatro } \\
\text { Hotel }\end{array}$ \\
\hline $\begin{array}{l}\text { Um homem sério } \\
\text { (A serious man) }\end{array}$ & EUA & $\begin{array}{l}\text { Joel e Ethan } \\
\text { Coen }\end{array}$ & $\begin{array}{l}\text { Professor de física vê sua vida mudar radicalmente após pedido de divórcio da } \\
\text { esposa. Ao mesmo tempo, enfrenta problemas no trabalho e em casa }\end{array}$ & $\begin{array}{l}\text { Casa } \\
\text { Escritório }\end{array}$ \\
\hline $\begin{array}{l}\text { O preço de uma } \\
\text { traição }(\text { Chloe })\end{array}$ & $\begin{array}{l}\text { França } \\
\text { Canadá } \\
\text { EUA }\end{array}$ & $\begin{array}{l}\text { Atom } \\
\text { Egoyan }\end{array}$ & $\begin{array}{l}\text { Após desconfiar que seu marido está lhe traindo, esposa contrata mulher de programa } \\
\text { para testa-lo. O envolvimento entre os dois acaba por denegrir a situação entre o } \\
\text { casal. }\end{array}$ & $\begin{array}{l}\text { Casa } \\
\text { Ruas }\end{array}$ \\
\hline \multicolumn{5}{|c|}{2010} \\
\hline Os Residentes & Brasil & $\begin{array}{l}\text { Tiago Mata } \\
\text { Machado }\end{array}$ & $\begin{array}{l}\text { Pessoas de diferentes famílias se alojam em uma casa abandonada. O modo de vida } \\
\text { do grupo passa a extrapolar os limites da casa e se espalhar pela cidade. }\end{array}$ & Casa \\
\hline Transeunte & Brasil & Eryk Rocha & $\begin{array}{l}\text { Expedito é um aposentado que leva uma vida solitária. Passa seu tempo ouvindo } \\
\text { rádio e acompanhando acontecimentos cotidianos. }\end{array}$ & Casa \\
\hline $\begin{array}{l}\text { Amor sem escalas } \\
\text { (Up in the Air) }\end{array}$ & EUA & $\begin{array}{l}\text { Jason } \\
\text { Reitman }\end{array}$ & $\begin{array}{l}\text { Ryan Bingham é um americano que vive para seu trabalho. Ele é um sujeito em } \\
\text { deslocamento contínuo, transitando entre aeroportos e hotéis. }\end{array}$ & $\begin{array}{l}\text { Hotéis } \\
\text { Aeroportos }\end{array}$ \\
\hline $\begin{array}{l}\text { Um lugar qualquer } \\
\text { (Somewhere) }\end{array}$ & EUA & $\begin{array}{l}\text { Sophia } \\
\text { Coppola }\end{array}$ & $\begin{array}{l}\text { Johnny é um ator que leva uma vida futil morando em hotéis. A tranquilidade de sua } \\
\text { vida acaba quando recebe a visita de sua filha de } 11 \text { anos. }\end{array}$ & Hotéis \\
\hline Biutiful & $\begin{array}{l}\text { Espanha } \\
\text { México }\end{array}$ & $\begin{array}{l}\text { Alejandro } \\
\text { González } \\
\text { Inárritu }\end{array}$ & $\begin{array}{l}\text { Uxbal cuida de seus filhos enquanto trabalha em negócios ilícitos. Após sentir dores, } \\
\text { descobre que está doente e tem poucos meses de vida. }\end{array}$ & Casa \\
\hline Os inquilinos & Brasil & $\begin{array}{l}\text { Sergio } \\
\text { Bianchi }\end{array}$ & $\begin{array}{l}\text { Walter e sua família vivem no subúrbio e se veem obrigados a conviver com a } \\
\text { violência urbana na vizinhança e na escola. }\end{array}$ & $\begin{array}{l}\text { Casa } \\
\text { Escola }\end{array}$ \\
\hline Un homme qui crie & $\begin{array}{l}\text { França } \\
\text { Bélgica } \\
\text { Chade }\end{array}$ & $\begin{array}{l}\text { Mahamat- } \\
\text { Saleh } \\
\text { Haroun }\end{array}$ & $\begin{array}{l}\text { Ex-campeão de natação trabalha na piscina de um hotel na República do Chade. } \\
\text { Quando investidores compram o hotel, ele é forçado a ceder seu lugar ao filho. }\end{array}$ & $\begin{array}{l}\text { Casa } \\
\text { Hotel }\end{array}$ \\
\hline Preciosa (Precious) & EUA & Lee Daniels & $\begin{array}{l}\text { Adolescente obesa e problemática engravida e é suspensa da escola. Após ser } \\
\text { transferida para escola especial, vê sua vida melhorar. }\end{array}$ & Casa \\
\hline $\begin{array}{l}\text { A empregada } \\
\text { (Hanyo) }\end{array}$ & Coréia do Sul & Im Sang-Soo & $\begin{array}{l}\text { Moça contratada como governanta em uma mansão de família se tornar amante do } \\
\text { patrão e passa a sofrer ameaças da família. }\end{array}$ & Casa \\
\hline Turnê (Tournée) & França & $\begin{array}{l}\text { Mathieu } \\
\text { Amalric }\end{array}$ & $\begin{array}{l}\text { Ex-produtor de televisão organiza turnê de um grupo de showgirls. De hotel em hotel, } \\
\text { as moças exibem um mundo de fantasia. }\end{array}$ & Hotéis \\
\hline
\end{tabular}




\begin{tabular}{|c|c|c|c|c|}
\hline $\begin{array}{l}\text { Film Socialisme } \\
\text { (Film Socialisme) }\end{array}$ & $\begin{array}{l}\text { Suíça } \\
\text { França }\end{array}$ & $\begin{array}{l}\text { Jean-Luc } \\
\text { Godard }\end{array}$ & $\begin{array}{l}\text { Num cruzeiro, passageiros debatem sobre história e finanças. Longe dali, família que } \\
\text { mora num posto de gasolina recebe a visita de uma jornalista. }\end{array}$ & $\begin{array}{l}\text { Cruzeiro } \\
\text { Posto de gasolina }\end{array}$ \\
\hline $\begin{array}{l}\text { A Separação } \\
\text { (Jodaeiye Nader az } \\
\text { Simin) }\end{array}$ & Irã & $\begin{array}{l}\text { Asghar } \\
\text { Farhadi }\end{array}$ & $\begin{array}{l}\text { Nader e Simin são casados e têm uma filha adolescente. A mãe cuida do sogro doente } \\
\text { e, cansada, decide deixar o Irã. Como o marido não concorda, Simin sai de casa e } \\
\text { inicia uma briga na justiça pela guarda da filha. }\end{array}$ & $\begin{array}{l}\text { Casa } \\
\text { Tribunal }\end{array}$ \\
\hline \multicolumn{5}{|c|}{2011} \\
\hline Natimorto & Brasil & $\begin{array}{l}\text { Paulo } \\
\text { Machline }\end{array}$ & $\begin{array}{l}\text { Uma cantora lírica e seu empresário passam a morar num quarto de hotel. Em torno } \\
\text { de maços de cigarros, os dias se passam. }\end{array}$ & Hotel \\
\hline $\begin{array}{l}\text { Um conto chinês } \\
\text { (Un cuento chino) }\end{array}$ & $\begin{array}{l}\text { Argentina } \\
\text { Espanha }\end{array}$ & $\begin{array}{l}\text { Sebastián } \\
\text { Borensztein }\end{array}$ & $\begin{array}{l}\text { Roberto vive recluso em sua casa, colecionando manias. Um dia, se vê compelido a } \\
\text { trazer Jun, um chinês perdido em Buenos Aires para habitar com ele. }\end{array}$ & $\begin{array}{l}\text { Casa } \\
\text { Loja }\end{array}$ \\
\hline Medianeras & $\begin{array}{l}\text { Espanha } \\
\text { Argentina } \\
\text { Alemanha }\end{array}$ & $\begin{array}{l}\text { Gustavo } \\
\text { Taretto }\end{array}$ & $\begin{array}{l}\text { Martin e Mariana foram feitos um para o outro. Em suas andanças digitais e percursos } \\
\text { pela cidade, eles se cruzam, mas nunca se encontram. }\end{array}$ & $\begin{array}{l}\text { Casa } \\
\text { Ruas }\end{array}$ \\
\hline $\begin{array}{l}\text { Pronto para } \\
\text { recomeçar } \\
\text { (Everything must go) }\end{array}$ & EUA & Dan Rush & $\begin{array}{l}\text { Nick perde o emprego no mesmo dia em que é abandonado por sua esposa. Sem ter } \\
\text { para onde ir, passa a morar no jardim de sua casa. }\end{array}$ & Jardim de casa \\
\hline Hoje & Brasil & Tata Amaral & $\begin{array}{l}\text { Ex-militante política compra apartamento com a indenização que recebeu do } \\
\text { desaparecimento de seu marido. Durante a mudança, passa a conviver com as } \\
\text { lembranças de um passado sofrido. }\end{array}$ & Casa \\
\hline $\begin{array}{l}\text { O garoto da } \\
\text { bicicleta } \\
\text { (Le gamin au vélo) }\end{array}$ & $\begin{array}{l}\text { França } \\
\text { Bélgica } \\
\text { Itália }\end{array}$ & $\begin{array}{l}\text { Pierre } \\
\text { Dardenne, } \\
\text { Luc Dardenne }\end{array}$ & $\begin{array}{l}\text { Garoto que mora em um orfanato recebe a permissão para passar os fins de semana } \\
\text { com dona de salão de beleza. No entanto, o menino não consegue se afastar de seu } \\
\text { pai biológico. }\end{array}$ & $\begin{array}{l}\text { Casa } \\
\text { Orfanato }\end{array}$ \\
\hline $\begin{array}{l}\text { O porto } \\
\text { (Le havre) }\end{array}$ & $\begin{array}{l}\text { Finlândia } \\
\text { Alemanha } \\
\text { França }\end{array}$ & $\begin{array}{l}\text { Aki } \\
\text { Kaurismäki }\end{array}$ & $\begin{array}{l}\text { Um velho engraxate abriga em sua casa um menino africano que chegou à cidade } \\
\text { portuária de Le Havre em um navio cargueiro. }\end{array}$ & $\begin{array}{l}\text { Casa } \\
\text { Rua }\end{array}$ \\
\hline $\begin{array}{l}\text { Loucamente } \\
\text { apaixonados } \\
\text { (Like crazy) }\end{array}$ & EUA & $\begin{array}{l}\text { Drake } \\
\text { Doremus }\end{array}$ & $\begin{array}{l}\text { A inglesa Anna estuda nos Estados Unidos e se apaixona por Jacob, um jovem } \\
\text { americano. Ela viola o prazo de seu visto e é expulsa do país. Morando em } \\
\text { continentes diferentes, eles tentam manter a relação à distância. }\end{array}$ & Casa \\
\hline $\begin{array}{l}\text { A Pele que habito } \\
\text { (La piel que habito) }\end{array}$ & Espanha & $\begin{array}{l}\text { Pedro } \\
\text { Almodóvar }\end{array}$ & $\begin{array}{l}\text { Cirurgião plástico perseguido por lembranças da esposa morta pratica estranhos } \\
\text { experimentos que ultrapassam os princípios éticos da medicina. }\end{array}$ & Casa \\
\hline $\begin{array}{l}\text { Os intocáveis } \\
\text { (Intouchables) }\end{array}$ & França & $\begin{array}{l}\text { Eric Toledano, } \\
\text { Olivier } \\
\text { Nakache }\end{array}$ & $\begin{array}{l}\text { O encontro improvável entre um aristocrata tetraplégico e um jovem da periferia que } \\
\text { é contratado como empregado em sua casa. }\end{array}$ & Casa \\
\hline
\end{tabular}




\begin{tabular}{|c|c|c|c|c|}
\hline $\begin{array}{l}\text { O que traz boas } \\
\text { novas (Monsieur } \\
\text { Lazhar) }\end{array}$ & Canadá & $\begin{array}{l}\text { Philippe } \\
\text { Falardeau }\end{array}$ & $\begin{array}{l}\text { Imigrante argelino substitui professora falecida de uma escola primária. Ninguém } \\
\text { suspeita que o professor possa ser deportado a qualquer momento. }\end{array}$ & Escola \\
\hline $\begin{array}{l}\text { Aqui entre nós } \\
\text { (Aqui entre nos) }\end{array}$ & México & $\begin{array}{l}\text { Patrícia } \\
\text { Martinez de } \\
\text { Velasco }\end{array}$ & $\begin{array}{l}\text { Os problemas cotidianos de uma família mexicana acabam levando ao divórcio e a } \\
\text { venda de sua casa. Enquanto coloca a vida em ordem, o pai passa a morar escondido } \\
\text { no sótão. }\end{array}$ & Casa \\
\hline \multicolumn{5}{|c|}{2012} \\
\hline $\begin{array}{l}\text { Dentro da casa } \\
\text { (Dans la maison) }\end{array}$ & França & François Ozon & $\begin{array}{l}\text { Professor descobre na redação de um aluno uma boa escritura, e acaba instigando } \\
\text { uma invasão de privacidade e envolvendo uma família em um jogo intrigante. }\end{array}$ & Casa \\
\hline Shame & Reino Unido & $\begin{array}{l}\text { Steve } \\
\text { McQueen }\end{array}$ & $\begin{array}{l}\text { Homem bem sucedido e sozinho em Nova York, viciado em sexo, acaba abalado } \\
\text { com a chegada de sua irmã. }\end{array}$ & Casa \\
\hline $\begin{array}{l}\text { Era uma vez, } \\
\text { Verônica }\end{array}$ & Brasil & $\begin{array}{l}\text { Marcelo } \\
\text { Gomes }\end{array}$ & $\begin{array}{l}\text { Verônica é estudante de medicina recém-formada e mora com o pai. Vive um } \\
\text { momento de incertezas no amor e na vida profissional. }\end{array}$ & $\begin{array}{l}\text { Casa } \\
\text { Hospital }\end{array}$ \\
\hline Louise Wimmer & França & $\begin{array}{l}\text { Cyril } \\
\text { Mennegun }\end{array}$ & $\begin{array}{l}\text { As vésperas de completar } 50 \text { anos, Louise vive em seu carro tendo como objetivo } \\
\text { conseguir um apartamento para morar. }\end{array}$ & Carro \\
\hline $\begin{array}{l}\text { Um alguém } \\
\text { apaixonado (Like } \\
\text { Someone in Love) }\end{array}$ & $\begin{array}{l}\text { França } \\
\text { Japão }\end{array}$ & $\begin{array}{l}\text { Abbas } \\
\text { Kiarostami }\end{array}$ & $\begin{array}{l}\text { Um velho e uma jovem se encontram em Tóquio. Ele a convida para ir a sua casa e } \\
\text { ela lhe oferece seu corpo. }\end{array}$ & Casa \\
\hline $\begin{array}{l}\text { Cosmópolis } \\
\text { (Cosmopolis) }\end{array}$ & $\begin{array}{l}\text { França } \\
\text { Canadá }\end{array}$ & $\begin{array}{l}\text { David } \\
\text { Cronenberg }\end{array}$ & $\begin{array}{l}\text { Eric Packer tenta chegar ao outro lado da cidade de Nova Iorque em um dia caótico, } \\
\text { ao mesmo tempo em que observa o colapso do seu império. }\end{array}$ & Carro \\
\hline $\begin{array}{l}\text { A Casa Vermelha } \\
\text { (The red house) }\end{array}$ & $\begin{array}{l}\text { Nova } \\
\text { Zelândia }\end{array}$ & Alyx Duncan & $\begin{array}{l}\text { Jia e Lee vivem juntos em uma casa cheia de memórias, mas Jia precisa voltar para } \\
\text { a casa de seus pais na China para cuidar deles. }\end{array}$ & Casa \\
\hline $\begin{array}{l}\text { Indomável } \\
\text { sonhadora } \\
\text { (Beasts of the } \\
\text { Southern Wild) }\end{array}$ & EUA & Benh Zeitlin & $\begin{array}{l}\text { Hushpuppy é uma menina que vive com seu pai doente em uma periferia às margens } \\
\text { da cidade. Aos poucos, aprende a lidar com as intempéries climáticas e da vida. }\end{array}$ & Moradia precária \\
\hline $\begin{array}{l}\text { Detroit Sem } \\
\text { Chumbo } \\
\text { (Detroit Unleaded) }\end{array}$ & USA & Rola Naschef & $\begin{array}{l}\text { Jovem libanês herda posto de gasolina em Detroit é obrigado a gerenciá-lo, } \\
\text { questionando seus valores, sua liberdade e independência. }\end{array}$ & Posto de gasolina \\
\hline $\begin{array}{l}\text { Para Roma com } \\
\text { amor } \\
\text { (To Rome with Love) }\end{array}$ & $\begin{array}{l}\text { EUA } \\
\text { Espanha } \\
\text { Itália }\end{array}$ & Woody Allen & $\begin{array}{l}\text { Arquiteto americano revive sua juventude em Roma; romano de classe média vira } \\
\text { celebridade; jovem casal provincial se desencontra; agente funerário vira cantor de } \\
\text { ópera. }\end{array}$ & $\begin{array}{l}\text { Hotel } \\
\text { Ruas } \\
\text { Casas }\end{array}$ \\
\hline $\begin{array}{l}\text { O exótico Hotel } \\
\text { Marigold (The best } \\
\text { exotic Marigold } \\
\text { Hotel) }\end{array}$ & EUA & John Madden & Aposentados se hospedam em hotel na Índia e vivem novas experiências. & $\begin{array}{l}\text { Hotel } \\
\text { Ruas }\end{array}$ \\
\hline
\end{tabular}




\begin{tabular}{|c|c|c|c|c|}
\hline $\begin{array}{l}\text { Depois de Lúcia } \\
\text { (Después de Lucía) }\end{array}$ & $\begin{array}{l}\text { México } \\
\text { França }\end{array}$ & Michel Franco & $\begin{array}{l}\text { Após morte da mãe, adolescente se muda para outra cidade com o pai. Na escola } \\
\text { nova, passa a sofrer bulling por parte dos colegas após ter vídeo íntimo distribuído } \\
\text { na internet. }\end{array}$ & $\begin{array}{l}\text { Escola } \\
\text { Casa }\end{array}$ \\
\hline Vendo ou alugo & Brasil & Betse de Paula & $\begin{array}{l}\text { Maria Alice vive com dificuldades financeiras e resolve vender sua casa para quitar } \\
\text { dívidas. O problema é que sua morada é velha e fica na entrada de uma favela do Rio } \\
\text { de Janeiro. }\end{array}$ & Casa \\
\hline $\begin{array}{l}\text { Crônicas do fim do } \\
\text { mundo (Crónica del } \\
\text { fin del mundo) }\end{array}$ & Colômbia & $\begin{array}{l}\text { Maurício } \\
\text { Cuervo } \\
\text { Rincón }\end{array}$ & $\begin{array}{l}\text { Pablo quase não sai de casa desde que sua esposa morreu. Em 2012, enquanto } \\
\text { aguarda o fim do mundo, convive com seus temores pessoais. }\end{array}$ & Casa \\
\hline $\begin{array}{l}\text { Eu e Você } \\
(I o \text { e te) }\end{array}$ & Itália & $\begin{array}{l}\text { Bernardo } \\
\text { Bertolucci }\end{array}$ & $\begin{array}{l}\text { Jovem introvertido se isola em sua casa até a chegada da menina Olivia que o atenta } \\
\text { para a vida fora de quadro paredes. }\end{array}$ & Casa \\
\hline $\begin{array}{l}\text { O quarteto } \\
\text { (Quartet) }\end{array}$ & EUA & $\begin{array}{l}\text { Dustin } \\
\text { Hoffman }\end{array}$ & $\begin{array}{l}\text { Diversas personalidades da música convivem em uma casa de repouso para músicos } \\
\text { relembrando os tempos de sucesso }\end{array}$ & Asilo \\
\hline $\begin{array}{l}\text { Amor } \\
(\text { Amour })\end{array}$ & $\begin{array}{l}\text { França } \\
\text { Alemanha }\end{array}$ & $\begin{array}{l}\text { Michael } \\
\text { Haneke }\end{array}$ & $\begin{array}{l}\text { O amor entre um homem idoso e sua esposa, professora de música aposentada, é } \\
\text { colocado à prova quando ela é vítima de um acidente vascular cerebral. }\end{array}$ & Casa \\
\hline O Som ao redor & Brasil & $\begin{array}{l}\text { Kleber } \\
\text { Mendonça } \\
\text { Filho }\end{array}$ & A vida cotidiana de uma vizinhança de classe-média na cidade de Recife. & Casa \\
\hline $\begin{array}{l}\text { Elefante Branco } \\
\text { (Elefante Blanco) }\end{array}$ & $\begin{array}{l}\text { Argentina } \\
\text { França } \\
\text { Espanha }\end{array}$ & Pablo Trapero & $\begin{array}{l}\text { Padres ajudam moradores de periferia de Buenos Aires se colocando contra a polícia } \\
\text { e os próprios sacerdotes da igreja. }\end{array}$ & $\begin{array}{l}\text { Prédio em } \\
\text { construção } \\
\text { Favela }\end{array}$ \\
\hline $\begin{array}{l}\text { O limpador } \\
\text { (El limpiador) }\end{array}$ & Peru & Adrian Saba & $\begin{array}{l}\text { Uma epidemia se propaga em Lima. Um homem é encarregado de limpar os resíduos } \\
\text { das mortes. Um dia encontra um garoto desamparado. }\end{array}$ & $\begin{array}{l}\text { Casas } \\
\text { Rua }\end{array}$ \\
\hline $\begin{array}{l}\text { As Sessões } \\
\text { (The Sessions) }\end{array}$ & EUA & Ben Lewin & Escritor tetraplégico procura terapeuta sexual que o inicia no sexo. & Casa \\
\hline $\begin{array}{l}\text { Uma Primavera } \\
\text { com Minha Mãe } \\
\text { (Quelques heures de } \\
\text { printemps) }\end{array}$ & França & $\begin{array}{l}\text { Stéphane } \\
\text { Brizé }\end{array}$ & $\begin{array}{l}\text { Alain volta a viver com sua mãe com quem tinha uma relação complicada. Sua } \\
\text { doença o fará repensar esta convivência. }\end{array}$ & Casa \\
\hline $\begin{array}{l}\text { O Sonho de Wadjda } \\
\text { (Wadjda) }\end{array}$ & $\begin{array}{l}\text { Arábia } \\
\text { Saudita, } \\
\text { Alemanha }\end{array}$ & $\begin{array}{l}\text { Haifaa Al } \\
\text { Mansour }\end{array}$ & $\begin{array}{l}\text { Wadjda vive na capital da Arábia Saudita. Um dia se encanta com uma bicicleta e } \\
\text { resolve compra-la, mas na sociedade em que vive, meninas não podem andar de } \\
\text { bicicleta. Ela decide ir em busca de seu sonho. }\end{array}$ & $\begin{array}{l}\text { Casa } \\
\text { Ruas }\end{array}$ \\
\hline \multicolumn{5}{|c|}{2013} \\
\hline La vie domestique & França & $\begin{array}{l}\text { Isabelle } \\
\text { Czajka } \\
\end{array}$ & $\begin{array}{l}\text { Mulher se vê dividida entre um possível trabalho e sua vida doméstica com filhos e } \\
\text { marido em uma cidade na periferia de Paris. }\end{array}$ & $\begin{array}{l}\text { Casa } \\
\text { Bairro }\end{array}$ \\
\hline
\end{tabular}




\begin{tabular}{|l|l|l|l|l|}
\hline $\begin{array}{l}\text { Azul é a cor mais } \\
\text { quente } \\
\text { (La vie d'Adéle) }\end{array}$ & França & $\begin{array}{l}\text { Abdellatif } \\
\text { Kechiche }\end{array}$ & $\begin{array}{l}\text { Garota de 15 anos vive paixão por outra garota. Enquanto enfrenta dificuldades com } \\
\text { moral vigente, vive as descobertas da adolescência. }\end{array}$ & $\begin{array}{l}\text { Casa } \\
\text { Escola } \\
\text { Ruas }\end{array}$ \\
\hline Ela (Her) & EUA & Spike Jonze & $\begin{array}{l}\text { Homem solitário se apaixona pela voz de um sistema operacional criado para } \\
\text { obedecer comandos de usuários. }\end{array}$ & $\begin{array}{l}\text { Casa } \\
\text { Escritório } \\
\text { Ruas }\end{array}$ \\
\hline $\begin{array}{l}\text { O Último Amor de } \\
\text { Mr. Morgan }(M r . \\
\text { Morgan's Lost Love) }\end{array}$ & $\begin{array}{l}\text { Bélgica } \\
\text { Alemanha } \\
\text { França } \\
\text { EUA }\end{array}$ & $\begin{array}{l}\text { Sandra } \\
\text { Nettelbeck }\end{array}$ & $\begin{array}{l}\text { Viúvo americano vive solitário em Paris após a morte de sua esposa. Um dia, conhece } \\
\text { uma jovem francesa professora de dança e inicia amizade que acaba transformando } \\
\text { suas vidas. }\end{array}$ & $\begin{array}{l}\text { Escola de dança } \\
\text { Ruas }\end{array}$ \\
\hline $\begin{array}{l}\text { O filho do outro (Le } \\
\text { fils de l'autre) }\end{array}$ & França & Lorraine Levy & $\begin{array}{l}\text { A vida das duas famílias se transforma radicalmente com a descoberta da troca de } \\
\text { seus filhos, um israelense e outro palestino. }\end{array}$ & $\begin{array}{l}\text { Casas } \\
\text { Quartel } \\
\text { Ruas }\end{array}$ \\
\hline $\begin{array}{l}\text { Cães errantes } \\
\text { (Xi You) }\end{array}$ & $\begin{array}{l}\text { China } \\
\text { França }\end{array}$ & $\begin{array}{l}\text { Ming-Liang } \\
\text { Tsai }\end{array}$ & $\begin{array}{l}\text { Um pai e seus dois filhos à margem do mercado de trabalho buscam a sobrevivência, } \\
\text { vivendo de forma precária. }\end{array}$ & $\begin{array}{l}\text { Locais } \\
\text { abandonados }\end{array}$ \\
\hline
\end{tabular}


2. Poema escrito por Jean-Luc Godard

\section{LA PAROISSE MORTE}

les noyaux assaillis par la poussière

les objectifs mal calés

les pieds remplis de terre

le négatif sous-exposé à pleine ouverture

le changement de bobine imprécis

la piste arrière humiliée

le devis qui ment

l'heure supplémentaire surpayée

la colleuse pas nettoyée

la vitesse de défilement américanisée

le jeux des acteurs qui opprime le jeu

le point régulièrement absent

le j'aime ou pas au lieu de ceci est bien ou mal

l'auto déglinguée de l'assistant

la synchronisation exacte tuée par le code

le documentaire divorcé de la fiction

le mille absent en fin de parcours

le montage loin du scénario

les sous-titres qui obscurcissent la lumière

le crayon gras du monteur obscène

la musique comme femme de chambre méprisée

l'étalonnage dominé par le film porno

les répétitions abandonnées au théâtre

l'art sur le répondeur de la culture

l'échange assassiné par le fax

les extérieurs occupés par l'équipe de parachutistes

le droit de l'auteur oublieux du devoir

la double collure faite sans amour

le générique interminable

l'enterrement de la 47 trente ans après celui de la double $\mathrm{X}$

la revue du cinéma-casino en place d'un sens critique

les travellings gémissant

les éclairages qui fusillent la lumière

la gloire des personnages plutôt que le bonheur de la personne

l'absence d'étude 